\author{
UNIVERSIDADE DE SÃO PAULO \\ ESCOLA DE EDUCAÇÃO FISICA E ESPORTE
}

\title{
PERFIL PERSÉFONE: UM ESTUDO SOBRE CRENÇAS RELIGIOSAS E LÓCUS DE CONTROLE DE ATLETAS DE HANDEBOL
}

Paulo Félix Marcelino Conceição

SÃO PAULO

2004 


\section{PERFIL PERSÉFONE: UM ESTUDO SOBRE CRENÇAS RELIGIOSAS E LÓCUS DE CONTROLE DE ATLETAS DE HANDEBOL}

PAULO FELIX MARCELINO CONCEIÇÃO

Dissertação apresentada à Escola de
Educação Física e Esporte da
Universidade de São Paulo, como
requisito parcial para obtenção do grau de
Mestre em Educação Física.

ORIENTADOR: PROF. DR. ANTONIO CARLOS SIMÕES 
Conceição, Paulo Felix Marcelino

Perfil Perséfone: um estudo sobre crenças religiosas e lócus de controle de atletas de handebol / Paulo Felix Marcelino Conceição. - São Paulo: [s.n.], 2004. xviii, 183p.

Dissertação (Mestrado) - Escola de Educação Física e Esporte da Universidade de São Paulo.

Orientador: Prof. Dr. Antonio Carlos Simões.

1. Psicologia do Esporte. 2. Handebol. Título. 


\section{AGRADECIMENTOS}

Ao Prof. Dr. Antonio Carlos Simões, pela inestimável orientação, grandiosidade, competência, suporte, desafios, confiança e amizade.

À Profa. Dr ${ }^{3}$. Luiza Klein Alonso, pela generosidade, colaboração e incentivo.

Ao Prof. Dr. José Geraldo de Paiva, pelas aulas de psicologia da religião.

À Profa $D r^{a}$ Marta Helena de Freitas, pelas inestimáveis contribuiçōes.

À Prof. Dr ${ }^{\mathrm{a}}$ Marilia Ferreira de Dela Coleta, pela valiosa colaboração.

À Profa $\mathrm{Dr}^{\text {a }}$ Myrian Krasilchic, pelo exemplo de vida e contribuição.

Ao Prof. Ms. Luis Fernando Baccheretti, pelas valorosas contribuiçōes.

À Profa Maria Lúcia Vieira Franco, pela colaboração no trabalho de revisão bibliográfica.

Aos Atletas de handebol pela participação atenção e afeto, por tornarem possivel a realização desta pesquisa.

À minha avó Marina, pela garra, aos meus pais Ana e Alvaro, pelo exemplo em todos os momentos de nossa vida.

Aos meus filhos Apolo, Gabriel e Angélica, pela compreensão.

À Sonia por todo amor. 


\section{SUMÁRIO}

Página

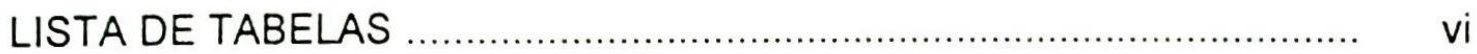

LISTA DE FIGURAS …............................................................ viii

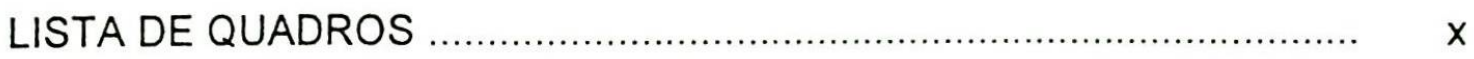

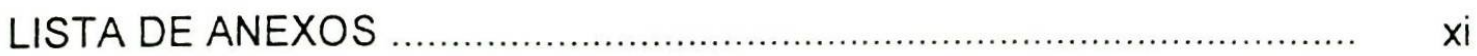

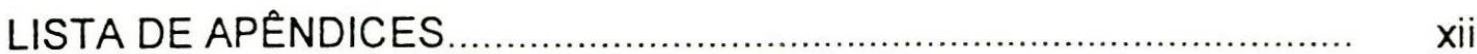

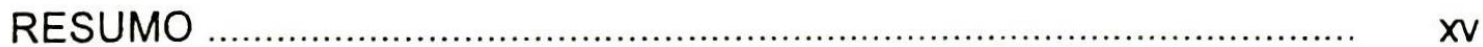

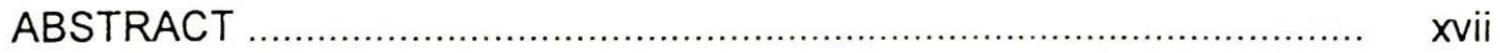

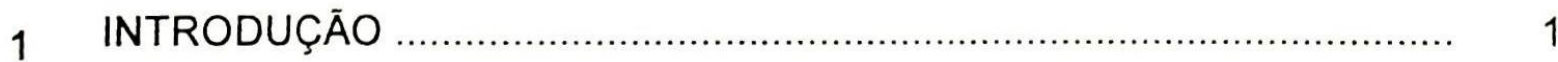

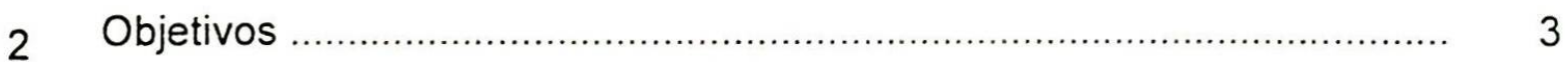

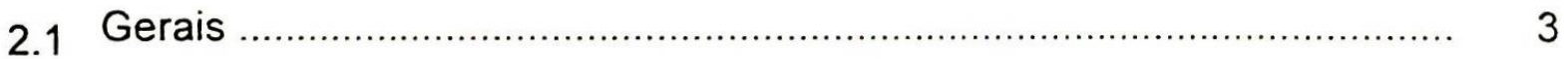

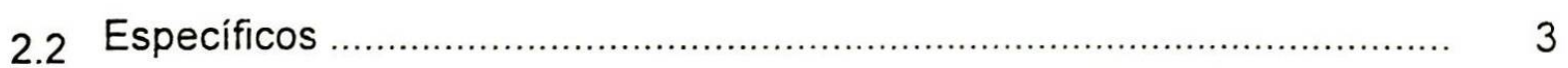

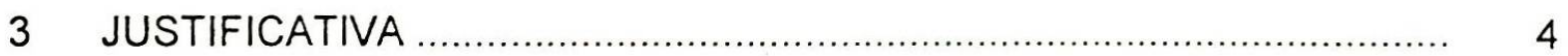

4 REVISÃO DE LITERATURA …........................................................ 5

4.10 mito Perséfone ..................................................................................... 5

4.2 A origem > esporte e espiritualidade < .......................................... 13

4.3 O senso religioso do povo brasileiro ................................................ 16

4.4 Consideraçōes a respeito do handebol ................................................... 18

4.5 A psicologia do esporte .................................................................... 20

4.6 Lócus de controle............................................................................. 22

4.7 As crenças religiosas por J. B. Pratt .................................................... 30

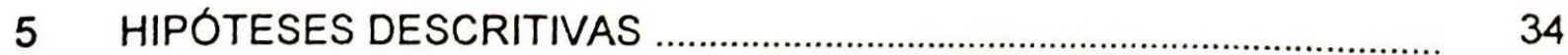




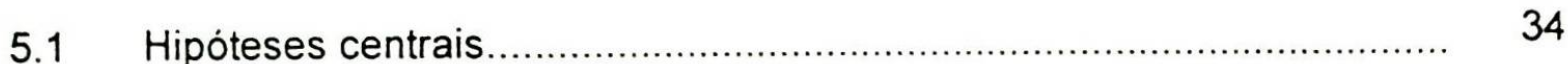

5.2 Hipóteses complementares.............................................................. 35

5.3 Hipóteses estatísticas ............................................................ 35

6 DELIMITAÇÃO DO ESTUDO ……………............................................ 36

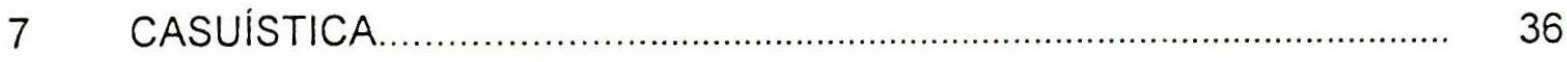

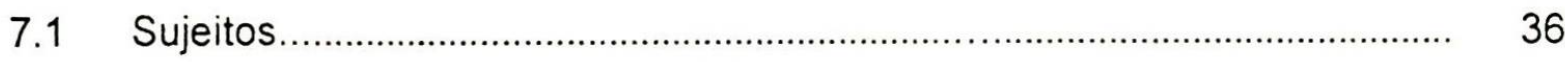

7.2 Procedimentos da pesquisa ….................................................... 37

7.3 Coleta de dados .................................................................................... 37

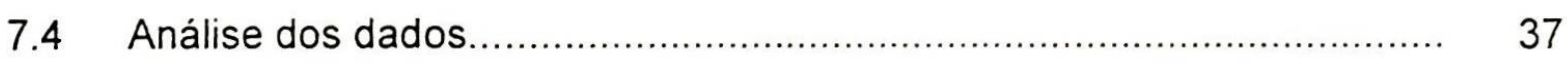

7.5 Desenvolvimento dos instrumentos de pesquisa.................................. 38

7.5.1 O Inventário de crenças religiosas no esporte (ICRE) ........................... 38

7.5.2 Primeira fase de desenvolvimento do Inventário de crenças religiosas no esporte: validação por especialistas.

7.5.3 Segunda fase de desenvolvimento do Inventário de crenças religiosas no esporte: validação por especialistas

7.6 A Escala multidimensional de lócus de controle do esporte (EMLCE) ...

7.6.1 Primeira fase de construção da escala multidimensional de lócus de controle do esporte.

7.6.2 Segunda fase de construção da escala multidimensional de lócus de controle do esporte.

7.6.3 Terceira fase da construção da escala multidimensional de lócus de controle do esporte: validação do conteúdo e do sistema de respostas.. 
7.6.4 Confiabilidade da escala multidimensional de lócus de controle do esporte: análise da consistência interna pelo alfa de Crombach

7.6.5 Validade fatorial da escala multidimensional de lócus de controle do esporte

8 Do projeto-piloto.

9 APRESENTAÇÃO DOS RESULTADOS

9.1 Características sociotécnicas dos sujeitos da pesquisa

9.2 Resultados obtidos com a Escala multidimensional de lócus de controle do esporte

9.3 Resultados obtidos com o Inventário Pratt de crenças religiosas no esporte (IPCRE).

9.4 Correlações entre lócus de controle e as caracteristicas sociotécnicas dos Atletas de Handebol de alto nivel de desempenho

9.5 Correlações entre lócus de controle e crenças religiosas de Atletas de Handebol de alto nivel de desempenho

10 PERSPECTIVAS CONCLUSIVAS

10.1 Recomendaçōes para estudos futuros

REFERÊNCIAS

ANEXOS 


\section{LISTA DE TABELAS}

Página

TABELA 1 - Análise da consistência interna da escala lócus de controle: valores de alfa de Crombach.

TABELA 2 - Análise fatorial: composição dos agrupamentos resultantes após rotação ortogonal (varimax).

TABELA 3 - Adequação da amostra e autovalores (eigenvalue) da análise fatorial da escala multidimensional de lócus de controle do esporte.

TABELA 4 - Análise fatorial: composição dos agrupamentos resultantes após rotação ortogonal (varimax), fixando-se o número de fatores em três

TABELA 5 - Distribuição geral da idade dos atletas de handebol de alto rendimento por faixas etárias.

TABELA 6 - Distribuição das freqüências absolutas e porcentuais relativos à naturalidade e nacionalidade dos atletas do handebol de alto rendimento.

TABELA 7 - Distribuição das freqüências absolutas e porcentuais relativos ao nivel de escolarização dos atletas de handebol de alto rendimento.

TABELA 8 - Lócus de controle: médias, medianas, desvios padrão, valores mínimos e máximos obtidos pelos atletas de handebol de alto nivel técnico de desempenho.

TABELA 9 - Valores médios de Lócus de controle pelas categorias de crenças religiosas obtidos na questão formulada com base na representação de Deus para o atleta

TABELA 10 - Cargas dos fatores rotacionais: varimax 
TABELA 11 - Cargas dos fatores rotacionais da escala multidimensional de lócus de controle do esporte pela rotação ortogonal: fixando-se três fatores

TABELA 12 - Estáticas descritivas das médias, desvio padrão, valores mínimos e máximos, sobre a variação dos niveis de respostas na escala likert pictográfica

TABELA 13 - Estatísticas descritivas das freqüências, porcentuais e distribuição das respostas na escala likert pictográfica no domínio lócus de controle interno

TABELA 14 - Estatisticas descritivas das freqüências, porcentuais e distribuição das respostas na escala likert pictográfica no dominio lócus de controle externo sorte-azar

TABELA 15 - Estatísticas descritivas das freqüências, porcentuais e distribuição das respostas na escala likert pictográfica no dominio lócus de controle externo pessoas poderosas 


\section{LISTA DE FIGURAS}

Página

FIGURA 1 - Deméter e Perséfone: Painel votivo às deusas Eleusinas.......

FIGURA 2 - Delegação chinesa com ramos de trigo durante a cerimônia de encerramento dos Jogos Olimpicos de Atenas 2004 ....... 7

FIGURA 3 - The abduction of Proserpine, Rembrandt ............................ 8

FIGURA 4 - A união de Hades e Perséfone ........................................... 11

FIGURA 5 - Os castigos de Atlas e Prometeu, Arkesilas 555 a. C ........... 12

FIGURA 6 - Valores porcentuais de distribuição de freqüência das idades dos atletas nas equipes femininas e masculinas.................... 65

FIGURA 7 - Descrição porcentual das religiōes dos atletas de handebol .. 68

FIGURA 8 - Porcentuais referentes às posições ocupadas pelos atletas na equipes pesquisadas.

FIGURA 9 - Descrição das crenças dos atletas, sob as perspectiva: 0 que a religião significa para você pessoalmente ? É.............. $\quad 75$

FIGURA 10 - Descrição das crenças dos atletas, sob as perspectiva: Como é Deus para você? …............................................ 78

FIGURA 11 - Descrição das crenças dos atletas, sob as perspectiva: Você acredita em Deus? É

FIGURA 12 - Descrição das crenças dos atletas, sob as perspectiva: Você acredita que Deus poderia ajudar a vencer obstáculos no esporte?

FIGURA 13 - Descrição das crenças dos atletas, sob as perspectiva: E nas derrotas Deus teria alguma participação?

FIGURA 14 - Descrição da opinião dos atletas sobre Deus como suporte psicológico: Deus seria um suporte psicológico para o atleta? 
Página

FIGURA 15 - Descrição do comportamento dos atletas sob a perspectiva: Você reza para obter a vitória nas competiçōes esportivas?...

FIGURA 16 - Descrição do comportamento dos atletas sob a perspectiva: E quando as coisas não dão certo você faz oraçōes ?

FIGURA 17 - Descrição da variabilidade dos escores de lócus de controle externo sorte-azar nas equipes femininas e masculinas.

FIGURA 18 - Correlação entre escores de lócus de controle externo sorteazar e as faixas etárias de atletas de handebol.

FIGURA 19 - Correlação entre escores de lócus de controle interno e posiçōes assumidas pelos atletas nas equipes

FIGURA 20 - Correlação entre escores de lócus de controle interno e a percepção de Deus na questão: Deus é algo real para você, tão real como um amigo terreno, embora diferente?

FIGURA 21 - Correlação entre escores de lócus de controle externo sorte-azar e a percepção de Deus na questão: Você acredita que Deus poderia ajudar a vencer obstáculos no esporte?

FIGURA 22 - Correlação entre escores médios de lócus de controle interno e a intenção da oração sob as perspectiva de: $E$ quando as coisas não dão certo você faz oraçōes?

FIGURA 23 - Correlação entre escores médios de lócus de controle interno e a intenção da oração sob as perspectiva de situaçōes difíceis 


\section{LISTA DE QUADROS}

Página

QUADRO 1 - Avaliação dos juizes sobre o conteúdo das questões do "Inventário de crenças religiosas no esporte": primeira fase. Avaliação dos juizes sobre o conteúdo das questōes do "Inventário de crenças religiosas no esporte": segunda fase

QUADRO 3 - Itens sobre lócus de controle interno da escala multidimensional de lócus de controle do esporte antes e depois de implementadas as sugestões dos juizes

QUADRO 4 Itens sobre lócus de controle externo sorte-azar da escala multidimensional de lócus de controle do esporte antes e depois de implementadas as sugestōes dos juizes

QUADRO 5 - Itens sobre lócus de controle externo pessoas poderosas da escala multidimensional de lócus de controle do esporte antes e depois de implementadas as sugestões dos juizes.

QUADRO 6 - Comparativo do alfa de Crombach na validação de escalas multidimensionais de lócus de controle em diferentes estudos.

QUADRO 7 - Análise das respostas sobre outros significados para as crenças religiosas, na questão: $O$ que a religião significa para você ? É.

QUADRO 8 - Análise das respostas sobre outros significados para as crenças religiosas, de acordo com o modelo empírico teórico de J. B. Pratt, na questão: Como é Deus para você?

QUADRO 9 - Análise das respostas sobre outros significados para as crenças religiosas de acordo com o modelo empírico teórico de J. B. Pratt na questão: Como é Deus para você? 


\section{LISTA DE ANEXOS}

Página

ANEXO । - Parecer do Comitê de Ética ……........................................ 110

ANEXO $\|$ - Termo de consentimento livre e informado do atleta............... 111

ANEXO III - Termo de consentimento livre e informado do técnico............ 112

ANEXO IV - Escala multidimensional de lócus de controle do esporte....... 113

ANEXO V - Inventário Pratt de crenças religiosas no esporte..................... 115 


\section{LISTA DE APÊNDICES}

APÊNDICE । - Material entregue à comissão julgadora sobre a avaliação do Inventário de Crenças Religiosas no Esporte: primeira fase do processo de construção do instrumento

APÊNDICE II - Comissão julgadora do Inventário de crenças religiosas no esporte na primeira fase do processo de construção do instrumento

APÊNDICE III - Parecer de Myriam Krasilchick …........................................ 123

APÊNDICE IV - Parecer de Luiz Fernando Bacchereti................................ 124

APÊNDICE V - Parecer de Sonia Maria da Silva....................................... 125

APÊNDICE VI - Parecer de Luiza Klein Alonso.......................................... 126

APÊNDICE VII - Material entregue à comissão julgadora sobre a avaliação do Inventário de crenças religiosas no esporte: segunda fase do processo de construção do instrumento

APÊNDICE VIII - Comissão julgadora do Inventário de crenças religiosas no esporte na segunda fase do processo de construção do instrumento.

APÊNDICE IX - Parecer de Luiza Klein Alonso........................................ 136

APÊNDICE X - Parecer de Luiz Fernando Bacchereti............................... 138

APÊNDICE XI - Parecer de Marta Helena de Freitas................................ 140

APÊNDICE XII - Comunicação pessoal com Ralph McKenna...................... 142

APÉNDICE XIII - Escala de lócus de controle de Rotter (original)................ 143

APÊNDICE XIV - Material entregue à comissão julgadora sobre a avaliação da escala multidimensional de lócus de controle do esporte: primeira fase de construção do instrumento..........

APENDICE XV - Comissão julgadora da escala multidimensional de lócus de controle do esporte: primeira fase do processo de construção do instrumento.

APENDICE XVI Parecer de Sonia Maria da Silva...................................... 148

APÉNDICE XVII - Parecer de Luiz Fernando Bacchareti................................ 155 
APÊNDICE XVIII - Parecer de Luiza Klein Alonso.

APÊNDICE XIX - Material entregue à comissão julgadora sobre a avaliação da Escala multidimensional de lócus de controle do esporte: segunda fase do processo de construção do instrumento.

APÊNDICE XX - Comissão julgadora da escala de lócus de controle do esporte: segunda fase do processo de construção do instrumento

APÊNDICE XXI - Parecer de Luiza Klein Alonso

APÊNDICE XXII - Parecer de Luiz Fernando Bacchareti

APÊNDICE XXIII - Parecer de Marilia Ferreira Dela Coleta

APÊNDICE XXIV - Tabela 10 - Fatores rotacionais varimax da Escala multidimensional de lócus de controle do esporte.

APÊNDICE XXV - Tabela 11 - Cargas dos fatores rotacionais da Escala multidimensional de lócus de controle do esporte: Fixando-se três fatores.

APÊNDICE XXVI - Tabela 12 - Descrição das médias, desvios-padrão, valores mínimos e máximos, pela variação dos niveis de respostas na escala likert pictográfica.

APÊNDICE XXVII - TABELA 13 - Descrição das freqüências, porcentuais e distribuição das respostas na escala likert pictográfica: lócus de controle interno.

APÊNDICE XXVIII - Tabela 14 - Descrição das freqüências, porcentuais e distribuição das respostas pela escala likert pictográfica: lócus de controle externo sorte-azar. 
APÊNDICE XXIX - TABELA 15 - Descrição sobre as freqüências, porcentuais e distribuição das respostas na escala likert pictográfica: lócus externo pessoas poderosas.

APÊNDICE XXX - Histograma de Freqüências sobre a variação e curva normal de distribuição ao lócus de controle interno.

APÊNDICE XXXI - Histograma de Freqüências sobre a variação e curva normal de distribuição ao lócus de controle externo sorteazar

APÊNDICE XXXII- Histograma de Freqüências sobre a variação e curva normal de distribuição ao lócus de controle externo pessoas poderosas 


\title{
RESUMO
}

\section{PERFIL PERSÉFONE: UM ESTUDO SOBRE CRENÇAS RELIGIOSAS E LOCCUS DE CONTROLE DE ATLETAS DE HANDEBOL}

\author{
Autor: PAULO FELIX MARCELINO CONCEIÇÃO \\ Orientador: Prof. Dr. ANTONIO CARLOS SIMÕES
}

O objetivo deste estudo foi introduzir na esfera da psicologia do esporte Brasileiro, os instrumentos: escala multidimensional de lócus de controle do esporte, definida pelos conceitos de lócus de controle interno, externo sorte-azar, externo pessoas poderosas e o inventário Pratt de crenças religiosas no esporte, caracterizado pelas crenças religiosas: primitiva, intelectual, emocional, e ético-moral. A legitimidade dos conteúdos destes instrumentos ocorreu com base em estratégias de validação por juizes especialistas. Foram aplicados em uma população de 111 atletas de handebol de alto nível técnico de desempenho de equipes femininas e masculinas. Por meio da análise da consistência interna, medida pelo alfa de Crombach, e análise fatorial da escala multidimencional de lócus de controle do esporte, pode-se constatar sua equivalência a outras escalas multidimensionais de lócus de controle desenvolvidas em áreas específicas de aplicação. Os resultados indicam diferenças significativas de lócus de controle entre variáveis sociotécnicas posições assumidas pelos atletas nas equipes, sexo, idade e as representações que os atletas possuem sobre a interferência divina no meio esportivo. A análise qualitativa indicou que o lócus de controle interno apresenta menores escores para atletas que possuem uma religiosidade voltada para a externalidade, pois quando em situações criticas, fazem orações invocando ajuda ou proteção, e maiores escores 
para àqueles atletas que tem uma religiosidade voltada para a internalidade, pois na mesma situação rezam almejando o equilíbrio interno ou a vitória.

Palavras-chave: psicologia; esporte; escala; lócus; crença; handebol 


\begin{abstract}
PERSEPHONE'S PROFILE: AN STUD ABOUT RELIGIOUS BELIEFS AND LOCUS CONTROL OF HANDBALL PLAYERS
\end{abstract}

\author{
Author: PAULO FELIX MARCELINO CONCEIÇÃO \\ Adviser: Prof. Dr. ANTONIO CARLOS SIMÕES
}

The purpose of this research was introduce in the sphere related to Brazilian sport psychology the instruments called: multidimensional sport locus of control scale, defined in the concepts of internal locus control, external chance, external powerful others and the instrument called inventory Pratt of religious beliefs in sport, characterized with the concepts of religious beliefs: primitive, intellectual, emotional and ethic-moral. The Legitimacies of the contents of this instruments occurred based on strategies of validation by expert's judges. Were subjects of this research 111 handball athletes of high-level technical performance from feminine and masculine equips. Through statistical analyzes of the multidimensional sport locus of control scale, was measured the internal consistence with alpha Cronbach and a confirmatory factorial analyses concluded for the statistical equivalence of this instrument relative compared to similar multidimensional locus of control scales developed for different areas with specifics applications. The results also indicates statistical significant differences between positions occupied for athletes in the equips, sex and age, in terms of qualitative analyses, the internal locus control, reveled low scores for that athletes with an external religiosity, because when they are in sports' critical situations they pray invoking for help and protection, and high scores for that 
athletes with religiosity orientated for the internality, therefore when they are in the same sports' critical situations they pray concerning for balance and the victory.

Key words: psychology; sport; scale; locus; belief; handball. 


\section{INTRODUÇĀO}

O espetáculo esportivo realmente, nunca se inicia sem que se faça antes 0 sinal da cruz, oração ou prece, suscitando uma série de questionamentos sobre os objetivos, significados e implicações psicológicas das crenças religiosas dos atletas. Assim, traz como resultado um conjunto de fatos das formas de comportamentos que caracterizam práticas e costumes, desde a origem do esporte na Grécia Clássica, vem se estendendo aos dias atuais.

A arte, o mito, a crença, a religião e o esporte trazem uma série de evidências sobre práticas e comportamentos comuns a diversos povos em distintas épocas e lugares ao longo de toda a história da humanidade, tornando claro a existência de um modelo básico de estrutura e funcionamento do aparelho psíquico humano, caracterizando o que JUNG (1971), definiu como inconsciente coletivo. Esses fatos mostram que a herança humana não seria apenas biológica, além da carga genética, também, seriam herdadas estruturas psicológicas arcaicas, os arquétipos, que por constituirem parte do inconsciente coletivo, adquirem representação no consciente, apenas por meio dos sonhos e dos simbolos, dentre os quais, Perséfone, personagem que vincula acontecimentos esportivos à espiritualidade na Grécia clássica, parte do legado cultural que vem se constituir como uma das principais influências no pensamento ocidental.

Para SIMÕES, CORTEZ e CONCEIÇÃO (2004) os arquétipos fazem parte da vida de todos, dando origem tanto as fantasias individuais quanto as mitologias.

Mas, nesta pesquisa, são enfocadas questōes relativas ao lócus de controle, como referencial psicossociológico de tomada de decisão em relação às variáveis sociotécnicas e as crenças religiosas dos atletas, discutidas da forma mais profunda do que é comum.

Desse modo, estudos com resultados importantes foram incluídos ou excluídos pelo fato de conterem conceitos que poderiam ser importantes e ou provocar erros desconhecidos de realização.

Nesta dissertação, os tópicos abrangidos são percebidos por muitos como representativos dos campos do esporte e da psicologia, dada a suposição de uma relação interativa mente-corpo, cujos aspectos psicológicos estruturados em torno 
das crenças religiosas e do lócus de controle são compreendidos, como fatores motivacionais, impulsionadores ou limitantes da ação dos atletas no esporte competitivo de desempenho. No entanto, dada a insipiência da psicologia do esporte no Brasil, faltam referenciais metodológicos e instrumentais para avaliar a temática, e surge como imperativo no decorrer da pesquisa, desenvolver um protocolo de avaliação sobre os domínios de crenças religiosas no esporte e uma escala de lócus de controle especifica ao esporte.

Por outro lado, existem certos principios de comportamento que são ditados pelo senso comum, e as crenças dos atletas possam ser usadas para fazer certas pressões, apontadas como uma ligação que eles fazem com a existência de um ser supremo - tendo em vista explicar algo que alegam acreditar. Revelar os princípios inseridos nessa aliança, é uma das tarefas dos pesquisadores, pois consiste em apurar esses fatos para otimizar um quadro referencial das crenças religiosas envolvidas com a conduta dos atletas dentro das equipes, variáveis sociotécnicas e a identificação da fonte referencial de lócus de controle atribuída pelos atletas de handebol em equipes masculinas e femininas no esporte de alto nivel técnico de desempenho.

A religião como orientação básica da vida aos valores éticos: respeito mútuo, diálogo, justiça, solidariedade e o espírito olimpico teriam perdido o sentido ou nunca teriam tido no âmbito da pós-modernidade.

GIOVANETTI (2002) afirma que dentre as várias facetas do homem moderno, a perda das referências apresenta-se como a principal delas na sociedade ocidental, de tal maneira que o espírito niilista imperaria na realidade de um grande número de pessoas, apoiado na tetralogia: hedonismo, consumismo, permissividade e relatividade.

Desta forma, no esporte, acredita-se que o comportamento dos atletas seja produto de seu próprio desempenho no contexto "homem-mulher máquina". Isto mostra que os atletas atuam por meio de forças sistemáticas, que influenciam seus comportamentos, conforme avançam as exigências. Nesse contexto, busca-se analisar o referencial de lócus de controle dos atletas, definido em torno do lócus de controle interno (self) e o locus de controle externo sorte-azar e pessoas poderosas. 


\section{Objetivos}

\subsection{Gerais}

- Implementar no cenário do esporte de alto nivel técnico de desempenho um protocolo de avaliação a respeito das crenças religiosas dos atletas, quanto à: crença primitiva (arquetipica), intelectual, emocional e ético-moral.

- Implementar uma escala multidimensional do lócus de controle, definida, estruturalmente, para avaliar os conceitos de lócus de controle interno e externo sorte-azar e pessoas poderosas.

\subsection{Especificos}

- Caracterizar que o Inventário Pratt de crenças religiosas no esporte que se define, estruturalmente, com base nas crenças: primitiva (arquetipica), intelectual, emocional e ético-moral, pode constituir um protocolo de pesquisa válido para descrever as crenças religiosas dos atletas de handebol.

- Verificar se a escala multidimensional do lócus de controle do esporte fundamentada pelo referencial de tomada de decisão dos atletas, envolvendo o lócus de controle interno (self), externo associado à sorte-azar e pessoas poderosas, pode constituir um sistema de avaliação eficiente e método eficaz para descrever as características psicológicas fundamentais que influenciam o comportamento dos atletas de handebol de ambos os sexos.

- Verificar se os itens que compõem a escala multidimensional do lócus de controle do esporte, definidos em torno do lócus interno, externo sorte-azar e externo pessoas poderosas, efetivamente, avaliam estas dimensões.

- Avaliar as possiveis relações entre lócus de controle, caracteristicas das crenças religiosas e variáveis sociotécnicas dos atletas de handebol de alto nivel técnico de desempenho nas equipes feminina e masculina 


\section{JUSTIFICATIVA}

$\mathrm{Na}$ origem, esporte e religião apresentavam-se quase que indistintamente fusionados, uma associação que contribuiu ao florescimento da cultura grega, que veio a se constituir como principal fonte de influência das ciências, filosofia, comportamento, arte e esporte ocidental.

$\mathrm{Na}$ atualidade, contrariando a idéia de que o esporte moderno teria sido completamente profanado, uma série de comportamentos, que podem ser verificados em vestiários, estádios, mídia e onde quer que se encontrem atletas, fatos associados às crenças e rituais religiosos, suscitando questionamentos sobre os significados e implicações psicológicas desses comportamentos no esporte.

Os meios de produção de bens alteram-se substancialmente, a automatização dos processos, implica em maior tempo ocioso.; a maior disponibilidade de alimentos e o controle de doenças geram maiores expectativas de vida. Portanto, surge como questão estratégica, o estimulo a modelos que favoreçam a saúde física e mental, contribuindo ao envelhecer saudável, dados os problemas que se verificam com as previdências sociais em todo o mundo, conferindo ao esporte grande importância no contexto global, especialmente no Brasil, onde o handebol surge como uma modalidade esportiva em ascensão.

As bases das equipes de handebol são as escolas, por isto, técnicos e atletas estão mais próximos à universidade, fato que contribui para viabilizar a pesquisa no esporte de alto nivel técnico de desempenho.

O esporte comporta valores indissociáveis do conjunto de traços culturais e ideológicos delineados no macro, predominantemente, orientado para aspectos orgânicos e funcionais do sistema que impelem e, ao mesmo tempo limitam às ações no esporte.

A psicologia do esporte revela-se ainda, como ciência incipiente no Brasil, carece de bases epistemológicas e metodológicas que favoreçam uma atuação mais técnica por parte dos profissionais, cujas açōes tem se caracterizado pelo uso de instrumentais inespecificos; pelas intervençōes de motivadores apenas em situações de crise, e que em alguns casos alternam-se entre padres e pais de santo. 


\section{REVISÃO DE LITERATURA}

Em vista dos conceitos e da temática desencadeada no contexto da literatura, quanto ao comportamento dos atletas no ambiente, como: caracteristicas psicológicas, antropológicas, crenças e valores, houve-se por bem organizar a revisão literária deste estudo por tópicos, a saber:

\subsection{O mito Perséfone}

Para JUNG (1976) o mito constitui-se em uma narrativa maravilhosa que trata justamente daquilo que quase sempre, também, è o objeto de fé, dotado de um universo próprio, não teria perdido sua vitalidade nem mesmo nos séculos da razão e no iluminismo. Pois, talvez seja o que melhor exprime a natureza do inconsciente coletivo, em que o arquétipo da mãe, identificado pelo mito de Deméter e Perséfone, se expressa numa diade, que poderia simbolizar um jogo entre o arcaico o novo, que se manifestaria numa espécie de protesto que reclama por reminiscências de um estado indescritivel de plenitude, incomparável às vicissitudes da vida real, permeada por esforços e cansaços no processo de adaptação e o sofrimento causado pelas inúmeras decepções da realidade, diante das complicações da vida, abafando a voz débil da natureza, roubando o entusiasmo, a coragem e o poder de decisão e após a celebração de um acordo com hades (aceitação de aspectos do inconsciente), tornar-se fonte da vida e motor para realizações.

As Agônes ${ }^{1}$ disputadas nas cidades da Ática, onde no santuário de Eleusis, famoso por seus cultos misteriosos às deusas agrárias Deméter e Perséfone, constituiam parte dos festivais esportivos e religiosos mais importantes realizados na Grécia, do neolítico ao período clássico. Frutos de uma complexa teogonia, que associava as deusas ao ritmo das estações do ano, em essência, significavam uma reverência aos Deuses pelos frutos colhidos da terra, ou como pedidos para melhores colheitas, sobretudo o trigo, associado à Perséfone ou Core, que significa semente, como pode ser constatado na FIGURA 1.

\footnotetext{
1 Agóne :jogo público, jogo de luta, jogo sacro, contenda realizada em festivais esportivos e religiosos na Grécia antiga. $\mathrm{Na}$ Roma antiga sacerdote que sacrificava um cordeiro nas festas agonais (HOUAISS, 2001 p.117 ).
} 


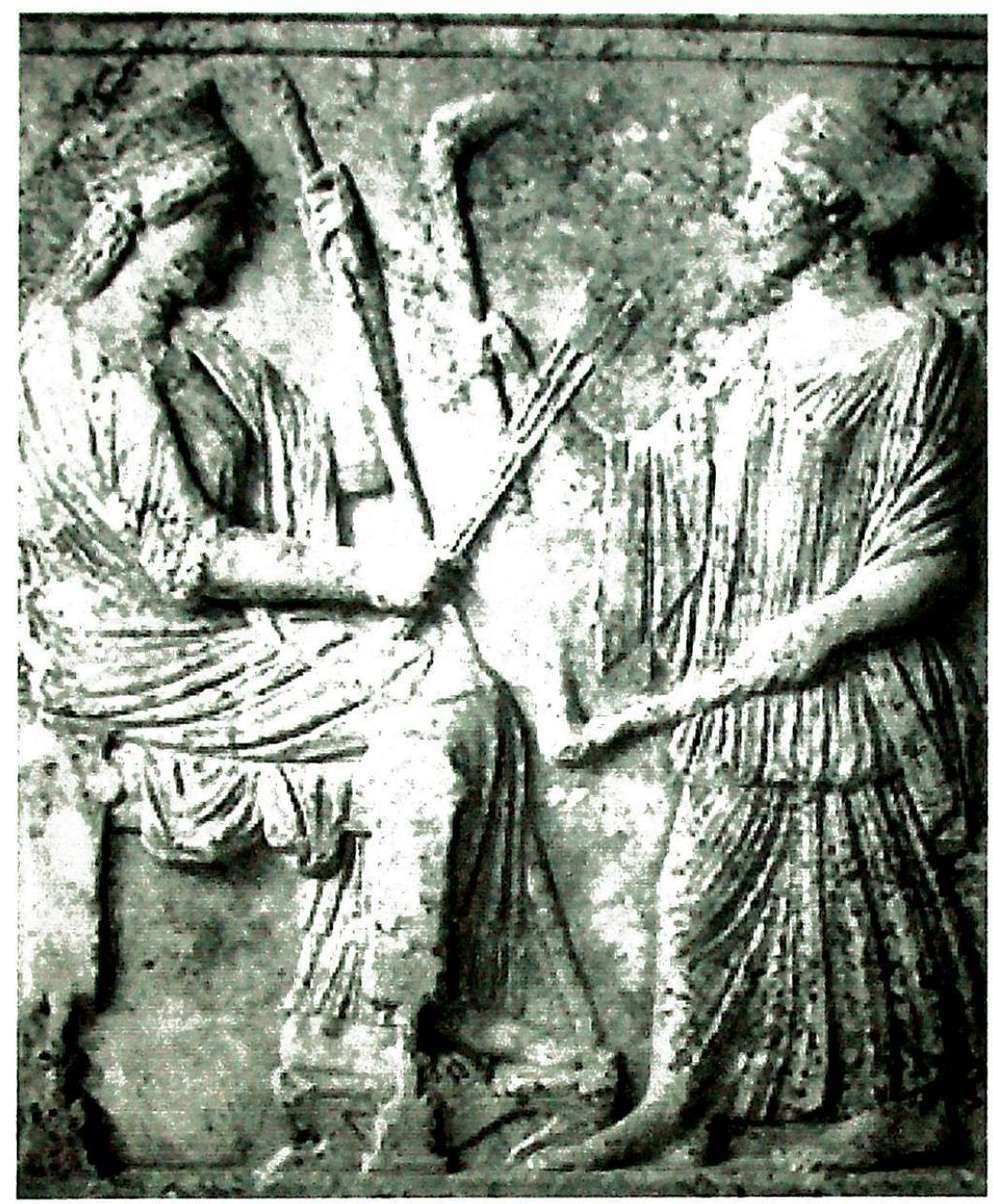

FIGURA 1 - Deméter e Perséfone: painel votivo às deusas Eleusinas (Fonte: HELLENIC MINISTRY OF CULTURE, 2004)

A FIGURA 1 destaca um baixo-relevo consagrado às deusas Deméter e Perséfone (440-430 a.C), mostrando um ritual, em que percebe-se símbolos, associados ao esporte olímpico. Deméter; à esquerda, oferece ramos de trigo a Perséfone; à direita, empunhando duas tochas. Acentuando a presença das deusas no imaginário do esporte.

O trigo, também, estava associado às festividades religiosas e esportivas consagradas à Zeus em Olímpia, onde medidas desse cereal eram oferecidas como recompensa aos atletas vencedores, constituindo um simbolismo que se estende aos dias atuais, como se pode perceber na FIGURA 2. 


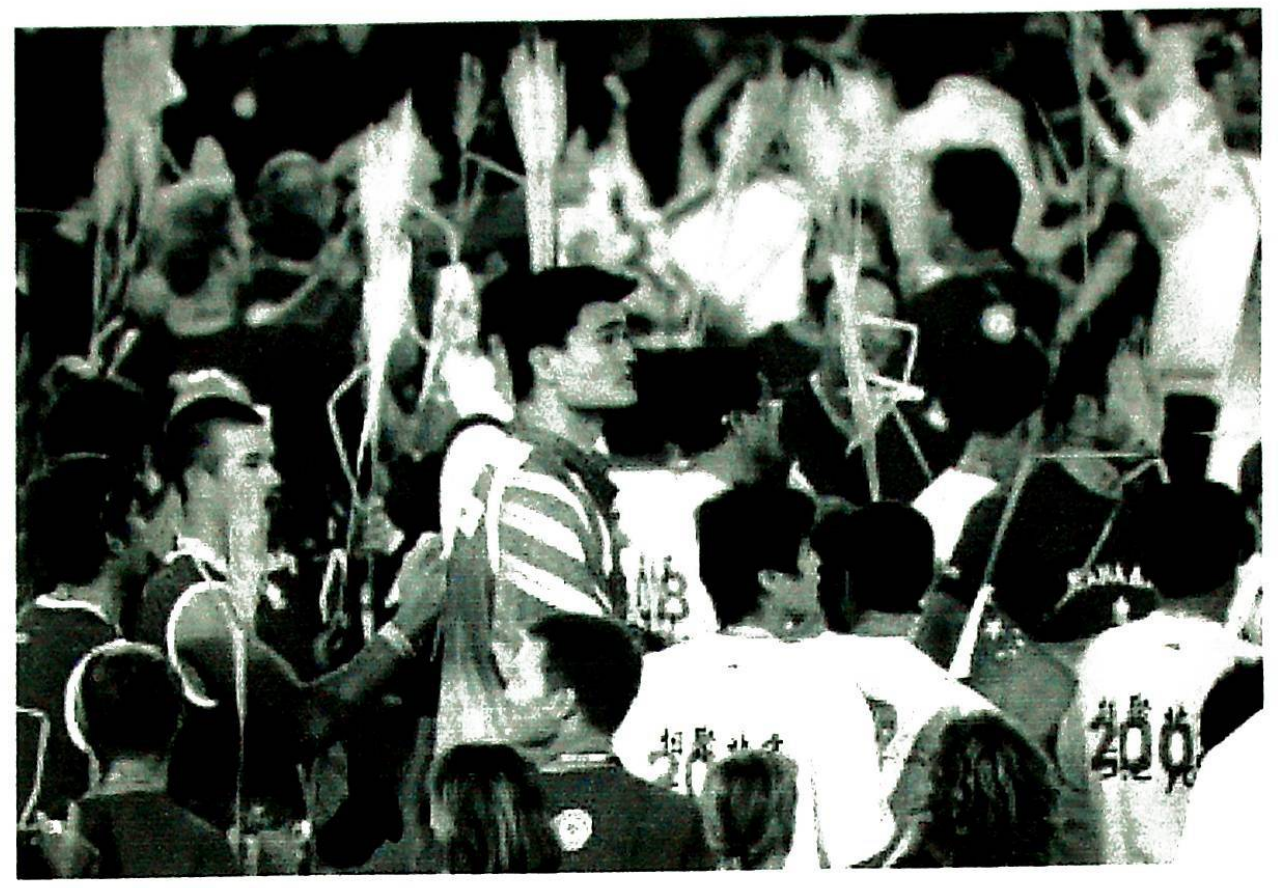

FIGURA 2 - Delegação chinesa com ramos de trigo durante a cerimônia de encerramento dos Jogos Olímpicos de Atenas 2004 (Fonte: UNIVERSO ON LINE OLÍMPIADAS, 2004)

Durante as festividades de encerramento dos Jogos Olímpicos 2004, um campo simbólico de trigo, disponibilizado em forma espiral, foi criado no estádio olímpico, revivendo-se rituais coreografados, representando o culto aos deuses e deusas do Olímpo. O simbolismo da semente, também, está presente na cultura chinesa, conforme demonstra JUNG (1964, p.136) em uma pintura datada do séc. XIX representando uma planta em processo de crescimento disposta em um altar de terra, cujo significado simbólico é associado ao processo de individuação ao self que o ego deve submeter-se. Desenvolvimento psicológico associado ao lócus de controle interno por VASCONCELLOS e DE ROSE (1991).

BRANDÃO (1998) relata que Perséfone, deusa Olímpica, filha de Deméter foi atraída ao mundo abaixo, entorpecida pelo perfume soporifero de uma flor de narciso, colocada estrategicamente por Hades à beira de um abismo. Esta passagem foi pintada por Rembrandt FIGURA 3. 


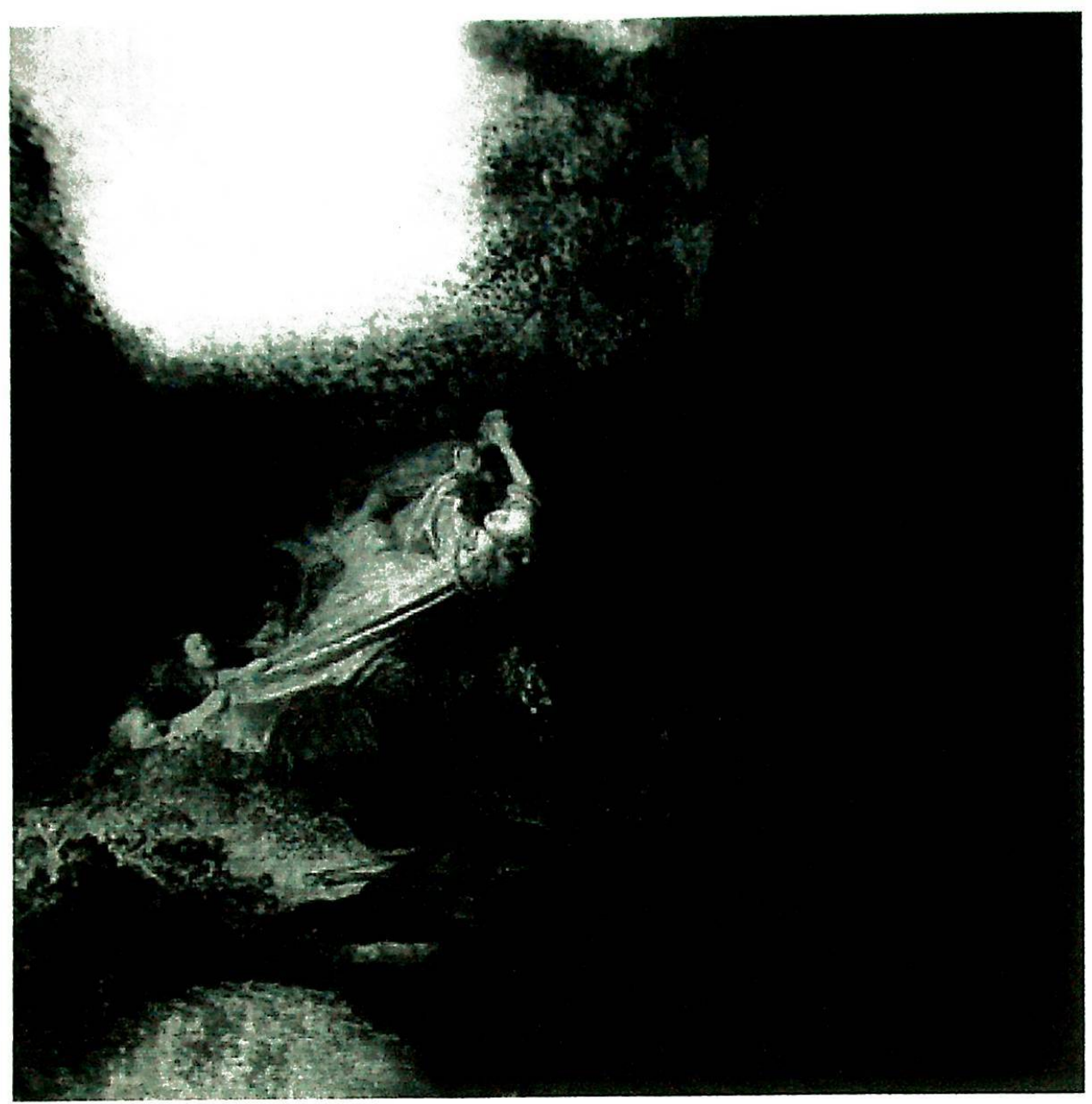

FIGURA 3 - The abduction of Proserpine, Rembrandt (Fonte: OLGA'S GALLERY, 2004)

A cultura Grega foi absorvida pela cultura romana, Prosérpina corresponde a Perséfone na mitologia romana. O ambiente escuro do quadro de Rembrandt apresentado na FIGURA 3 ilustra a trajetória da deusa ao hades, o mundo ctônio, associado simbolicamente ao inconsciente, em que a sombra constitui um dos arquétipos, que mais intensamente perturbam a consciência do eu, dado que representa traços obscuros do caráter e inferioridades das pessoas, constituindo problemas de ordem moral que desafiam a personalidade do eu (JUNG, 1976)

Na saga de Perséfone ao Hades, Deméter, a mãe, contrariada pelo desaparecimento da filha, lança um grande período de secas sobre a terra, causando enormes danos às plantações. 
Para acalmar a füria devastadora de Deméter, os homens passam a prestar homenagens a deusa, construindo-lhe santuários, os quais são referidos por BRANDÃO (1998) e ROMANO (1985), sobre ruinas de templos dedicados à Deméter-Perséfone em sitios arqueológicos localizados na Grécia.

Contrariada pelo rapto da filha, Deméter teria se recolhido nesses santuários, ao passo que os homens empenhavam-se em prestar-lhe homenagens na tentativa de aplacar sua fúria. Mas, a Deusa só se acalmaria quando Perséfone retorna ao mundo da luz, pela interferência de Zeus, diante do qual Hades curva-se, cedendo à vontade do irmão, e liberta Perséfone. Entretanto, antes de libertá-la, Hades introduz habilmente na boca de Perséfone uma semente de romã, símbolo da união entre os dois. As frutas com muitas sementes, eram tidas como simbolos da fertilidade e da fatura na antiga Grécia.

Desta forma, Perséfone ficou eternamente ligada ao mundo abaixo (o inconsciente), só após celebrar um acordo com Hades passa a conviver durante um período na companhia de Deméter e outro com Hades.

No periodo que Perséfone retorna ao convívio da mãe, Deméter devolve a fertilidade à terra, por ocasião da época das colheitas, época em que se realizam as jogos agônes inseridas nas festividades eleusinas no templo dedicado a DeméterPerséfone na cidade de Elêusis.

Os mistérios de Elêusis assinalavam os caminhos que os homens espirituais deviam se manter para poderem iniciar-se nos grandes mistérios ŏ öixos అعòy̆, onde somente Deus habita (JUNG, 1976 p. 207).

O politeísmo grego precede as grandes religiões monoteistas, que possuem em comum uma série de mitos e rituais que se assemelham aos mitos gregos e romanos, e a exemplo destes, suas interpretações extrapolam o sentido concreto, portanto, são os significados simbólicos que constituem a grande riqueza do mito.

Para MURARO (1988) o Hinduismo; o Judaismo; o Cristianismo e o Islamismo estão intimamente ligados aos sistemas econômicos em que se inserem, o mesmo seria válido para à religião na Grécia Clássica, onde as deusas Deméter e Perséfone tinham grande importância, responsáveis pelas sementes, delas dependiam os frutos e o bem estar da coletividade. 
De acordo com R. M. Muraro os mistérios de Elêusis são um reflexo da democracia que vislumbra-se na cultura grega, dada a existência e a importância que as deusas tinham ao lado dos deuses, constituindo um universo cultural, que evidência uma série de arquétipos, fonte do pensamento filosófico e científico que forma as bases em que se fundamenta a sociedade contemporânea ocidental.

Observa-se o fato de que pela análise simbólica o esporte ganha importância, dado que transporta ao plano simbólico os conflitos psíquicos e concretos, por isso, a exemplo dos grande mistérios religiosos, poderia representar uma maneira mais evoluida do ser humano expressar-se no mundo.

O mito de Perséfone oferece uma metáfora ao caminho de desenvolvimento e integração do ego em direção ao self, a totalidade psíquica, um processo de integração na personalidade de conteúdos inconscientes, permitindo a ampliação da consciência do eu e conferindo as pessoas maior vigor e capacidade de concentração, pela economia da energia gasta em conflitos. O mito mostra que para obter a capacidade de empenhar-se no esporte é preciso integrar na personalidade aspectos inconscientes, o que poderia conferir ao atleta maior capacidade para enfrentar o denominado jogo psicológico, o calcanhar de Aquiles.

Perséfone retorna ao plano da luz - a consciência realizada como mulher, um simbolo para as riquezas que podem advir pela integração dos aspetos inconscientes na personalidade, processo que é utilizado como tema em uma ilustração francesa datada do séc. XV, destacada na FIGURA 4 


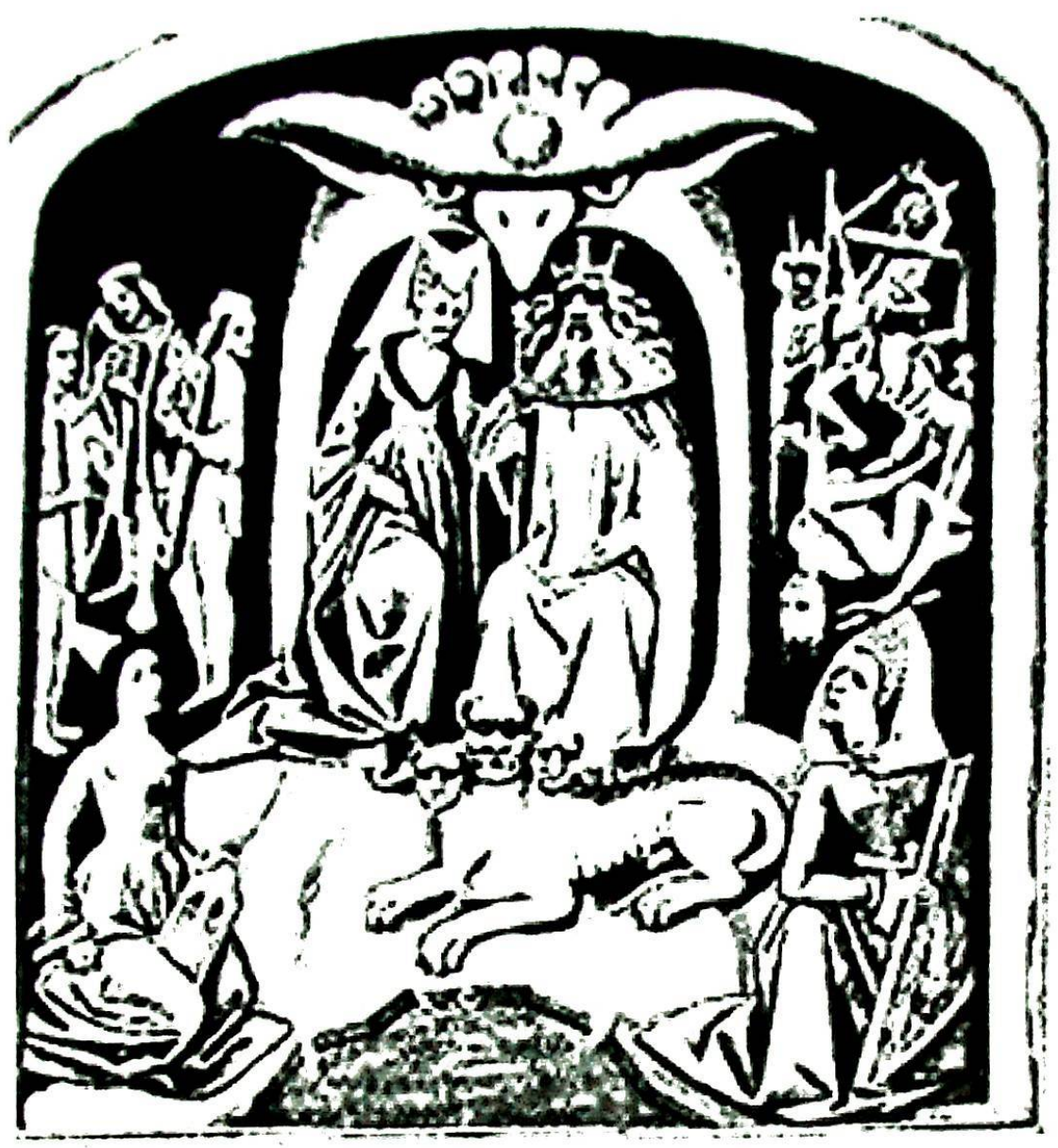

FIGURA 4 - A união de Hades e Perséfone, llustração francesa do séc. XV (Fonte UNIVERSITY OF VICTORY, 2004)

Esta gravura poderia simbolizar o coroamento do processo de desenvolvimento do self, pela inclusão na personalidade de aspectos do inconsciente, representado pelo coroamento da união entre Hades (o inconsciente) e Perséfone ou Core, a semente, a origem de algo que está por vir, fecunda, mas que apenas realizar-se-a ao longo de um processo cíclico.

O enfoque curativo da saúde constitui-se como advento da modernidade, na Grécia Clássica o enfoque é holístico, e a saúde mental precursora do bem estar físico, processo evidenciado pelo emprego da terapêutica do sonho no culto a Esculápio, deus ao qual os homens solicitavam um sonho para indicar-lhes 0 caminho da cura, cujo símbolo é a serpente, um representando do hades que transita pela superfície entre os mundos acima e a abaixo, animal que representa a 
doença, pois possui sangue frio, surge de surpresa, ou espontaneamente, não reconhece o homem e passa por cima de tudo que se interpõe ao seu caminho, assim, expressa ao mesmo tempo o terror do homem e um temor reverencial, mostrado em uma série de cultos, em que a serpente é reverenciada JUNG (1964).

A serpente, também é associada aos conflitos psicológicos, conforme ilustração de um kylix, atribuído à Arkésilas 555 a. C, em que Atlas incumbido de carregar o mundo nas costas, analogia à conflitos resultante de uma possível personalidade neurótica, é surpreendido por uma serpente, conforme ilustrado na FIGURA 5.

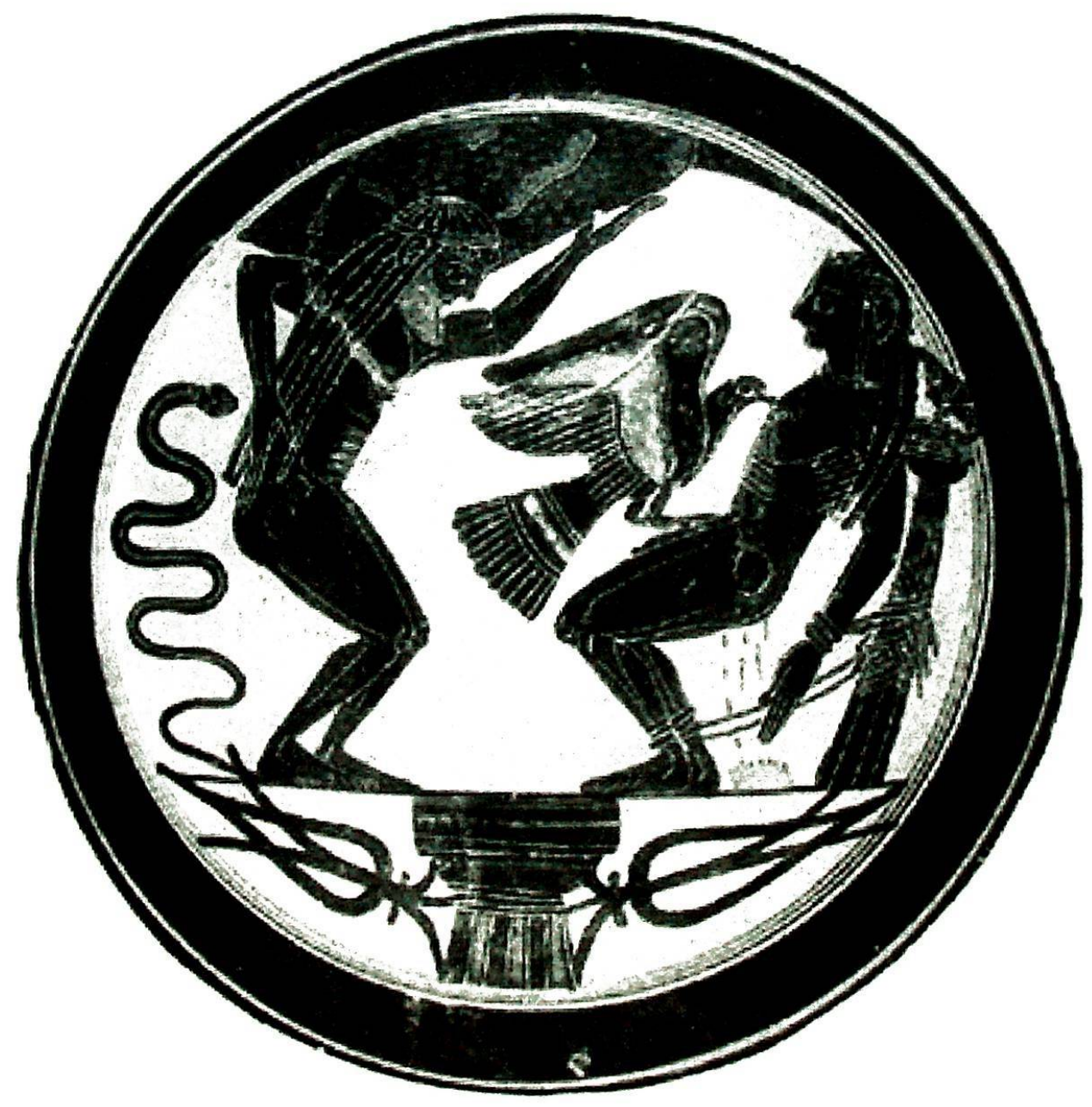

FIGURA 5 - Os castigos de Atlas e Prometeu, Arkesilas 555 a. C (Fonte MUSEO GREGORIANO ETRUSCO, 2004). 
NA FIGURA 5 nota-se ao lado direito, a figura de Prometeu, que tem o coração sendo devorado por uma águia, durante o dia, e que irá se reconstituir durante a noite, para ser novamente devorado ao amanhecer, castigo que recebeu dos Deuses por ter-lhes roubado o fogo e tê-lo entregue aos homens, cujos significados simbólicos ao fogo a intelectualidade, o conhecimento, os mistérios como eliciadores de uma angustia que devora o coração.

Esta passagem também poderia reforçar o sentido daquilo que disse Pelé, quando foi homenageado nos EUA, possivelmente uma das chaves para o sucesso no esporte, assim como, em outras áreas da atividade humana love.

\subsection{A origem >esporte e espiritualidade $<$}

Os fatos associados em virtude do significado psicológico aos mitos mostram que na Grécia Clássica, aspectos relativos ao universo religioso e esportivo apresentavam-se intimamente relacionados, simbolo da unidade e do espírito helênico, atividades com fins políticos e educativos, objetivavam a promoção e a manutenção da saúde física e mental nas acrópoles.

A ODISSÉIA (700 a. C.), narra em tom de epopéia os acontecimentos no retorno á pátria dos heróis Gregos depois da guerra de Tróia, enquanto restam arestas e feridas de guerra. Na rapsódia VIII, Homero faz referencias à realização de provas de atletismo, destacando um outro aspecto do esporte, o expiatório. Instituidas por Alcino, as disputas atléticas, tinham o propósito de homenagear Eurialo e buscar sua reconciliação com Ulisses, cujas relações foram abaladas devido a afrontas ocorridas durante a guerra. Desta forma, Homero, evidencia um outro sentido ao esporte, o de ato expurgatório, permitindo estabelecer um paralelo entre o esporte e o sacrifício religioso, com proveito de corrigir erros do passado.

A ILÍADA (700 a. C.), também atribuida a Homero, historicamente antecede a Odisséia, pois retrata os acontecimentos antes e durante a guerra de Tróia. Neste processo são estabelecidos vínculos entre os jogos praticados na era Clássica em estreita relação do esporte com deuses e divindades. No canto XXIII da lliada “Jogos em Honra a Pátroclo", o esporte é apresentado pelo poeta entre as honras funerais em homenagem a Pátroclo, herói que teria morrido, após ultrapassar o 
métron (limite), cujo corpo é cremado por Aquiles, seu grande amigo, em uma grande pira tripode, após foi construido um enorme tumulo onde doze jovens troianos foram sacrificados

.... pusieron al fuego un gran tripode... pero Aquiles se negó obstinadamente, e hizo además un juramento: - ¡No, por Zeus que es el supremo e más poderoso de los dioses! No es justo que el baño moje mi cabeza hasta que ponga a Patroclo en la pira, le erija un túmulo y me corte la cabellera...

HOMERO 700 a. C. (Iliada Canto XXIII Juegos en honor de Pátroclo, 1999 p. 372)

Os escritos poéticos de Homero não se constituem como um documento histórico propriamente dito; no entanto, as evidências relatadas pelo poeta enriquecem os significados em torno do simbolismo do esporte e sua relação com a espiritualidade, pois fornece um outro significado à pira, além das referências a Aquiles, herói mitológico tido como invencivel, mas, com um ponto fraco, o calcanhar, uma simbologia que poderia ser vinculada à vulnerabilidade psicológica dos atletas.

As referências a Pátroclo, que teria morrido após ultrapassar o métron, ou seja, o equilibrio e o bom senso, constituem-se em um desafio constante aos atletas diante de pressōes externas, demandas e necessidades internas para vencer; algumas vezes, a qualquer custo, implicando passar do limite e arcar com sérias conseqüências.

Homero menciona um comportamento relativamente comum no universo místico-esportivo, referindo-se àquilo que NEWTON e MINUTAGLIO (1999), BROMBERGER (2001) denominam como "complexo de Sansão", hábito comum entre os atletas de não cortar os cabelos nem fazer a barba durante um campeonato ou ciclo de partidas.

As evidências relatadas por Homero quanto aos jogos e disputas são confirmadas pelas primeiras listas dos Jogos Olimpicos da antigüidade, datadas de 776 a.C; entretanto, a relação entre esporte e espiritualidade seria mais antiga, o que contraria essas provas. 
Na Grécia, achados em sitios arqueológicos, referidos por ROMANO (1985), disponibilizados pelo departamento de estudos mediterrâneos da University of Pennsylvania Museum of Archaeology and Anthropolog - The Real History of the Ancient Olympic Games, revelaram a descoberta de uma série de tripodes - vasos antigos com três pés, de bronze, datados do séc. IX a.C, nos quais, o azeite de oliva oferecido como recompensa aos atletas vencedores nos jogos realizados no templo de Zeus em Olimpia era depositado. Assim, os primeiros jogos teriam ocorrido por volta de 900 a.C., revelando uma série de simbolos esportivos e religiosos presentes no esporte contemporâneo e em rituais religiosos praticados na atualidade

O azeite de oliva oferecido aos atletas no templo de Zeus em Olímpia, não era a única premiação ofertada aos atletas vencedores. Além de bens materiais, os prêmios simbólicos variavam, segundo a regiāo onde aconteciam os festivais religioso-esportivos e de acordo com as divindades que honravam: medidas de trigo, vinho, ramos de oliveira e sacrificio de animais, entre outras oferendas consagradas aos deuses e oferecidas aos atletas, que mostram uma série de práticas apoiadas no universo dos esportes e costumes religiosos que se manifestam no presente.

Esses indícios alinham-se às concepções de FREUD (1914) em análise sobre a gênese das religiões, as quais, seriam originárias de um grande número de costumes e práticas comuns em várias sociedades antigas e modernas, remanescentes de uma época totêmica, nas quais os produtos ofertados em sacrificio aos deuses podiam ser comidos ou bebidos, como: a carne, os cereais, as frutas, o vinho e o óleo.

A própria origem dos Jogos Olimpicos é mítica, conforme citam GOLDEN (1998), BRANDÃO (1998) pois teriam sido instituidos por Héracles, um herói dotado de grande força e coragem que realizou feitos e proezas incríveis, instituindo jogos e disputas atléticas para homenagear Zeus em agradecimento às interferências favoráveis no cumprimento dos desafios que lhes foram impostos ao longo de sua saga.

As façanhas de Héracles ou Hércules não se esgotavam na demonstração de força, o herói derrotou monstros, conquistou cidades e seus reis, além de vencer em combate os próprios deuses. Fatos que colocam em relevo a complexidade do "fenômeno", inferindo na necessidade de conhecimento e análise dos mitos. Por 
outro lado, esta análise fornece subsidios para uma compreensão da dinâmica e do simbolismo do esporte, além de considerar um conjunto de fatores culturais, sociais e psicológicos intervenientes na vida dos atletas.

\subsection{O senso religioso do povo brasileiro}

O Brasil é um pais de religião predominantemente católica, de acordo com os dados estatísticos publicados pelo INSTITUTO BRASILEIRO DE GEOGRAFIA E ESTATÍSTICA (IBGE, 2000), relativos ao Censo Demográfico, no total de 169.872.856 pessoas, $124.980 .132(73,57 \%)$ declararam que professam a religião católica apostólica romana; $26.184 .491(15,41 \%)$ são evangélicas; 17.617 .307 $(10,37 \%) ; 2.262 .401(1,33 \%)$ espiritas; $1.104 .886(0,65 \%)$ testemunhas de Jeová; $397.431(0,23 \%)$ umbandistas; $127.582(0,07 \%)$ candomblés e $12.492 .403(7,35 \%)$ declaram-se sem religião.

A espiritualidade de nosso povo extrapola as esferas relativas ao divino e à mediação de questōes de cunho existencial, fazendo-se presente em todas as atividades das pessoas, entre elas, no esporte.

Embora a grande maioria da população declare-se católica, a religião professada pelo povo, por vezes, distancia-se dos cânones clássicos do catolicismo, existindo certo afastamento entre os preceitos do catolicismo oficial, professado pela igreja e os elementos culturais oriundos da espiritualidade dos povos que constituiram a nação brasileira, entre os quais: o negro, o índio e o português.

A religiosidade dos portugueses, veio no início de nossa colonização, marcada pelas crenças de pessoas comuns, do povo que, inicialmente trouxerem uma religião de apelo mais popular, permeada por elementos do universo cultural europeu, alternada pela bruxaria da Idade Medieval que, aos poucos, foi se misturando à religiosidade praticada pelos africanos, cuja práxis religiosa revela uma teogonia marcada pela personificação das forças da natureza em entidades, como os orixás - guias da vida, do amor e da morte.

A fusão da religiosidade dos negros e portugueses, com os traços do animismo indigena pode ser observada nas diversas nuanças que distinguem a espiritualidade do povo brasileiro, manifesta pela crença em deuses e entidades que 
já habitariam as matas, rios, mares e fontes muito antes da chegada dos portugueses, negros, espanhóis, holandeses, italianos, alemães, japoneses entre outros povos que colonizaram o Brasil, resultando o sincretismo religioso.

Para CASCUDO (2001), as crenças e superstições são características marcantes da cultura do brasileiro, expressas pela influência religiosa dos diversos povos que constituiram a nação.

Em Processos Psicológicos na Representação Religiosa, AUGRAS (2002) caracteriza como clima de teologia popular, marcado pela devoção aos santos, o cumprimento de promessas, peregrinaçōes, procissões, oferendas, despachos, entre diversos rituais que se mantêm vinculados às tradições religiosas dos povos que constituiram a nação brasileira como resultante de um arcaismo, fruto da fusão religiosa de elementos da origem "luso-brasileira" que continuam presentes, fatos que podem ser constatados de forma espetacular no mundo dos esportes.

Naturalmente, o universo cultural e religioso permeia todas as esferas da vida cotidiana. As crenças populares, a politica, o público e a comunicação de massa estão entre as forças que compõem o universo macrossociológico do esporte, intermediando a relação com o microssociológico - atletas, ligas e clubes em um movimento de influências mútuas que interfere no desempenho esportivo e expressa-se em realidades fenomenológicas definiveis (SIMÕES, 1999).

Nesse contexto, o ritual no esporte forneceria uma chave ao entendimento do próprio espetáculo esportivo. BROMBERGER (2001) cita que o espetáculo esportivo apresenta-se, como um elemento catártico que reedita o significado mágico simbólico das disputas esportivas da Antigüidade, remetendo às origens do esporte na Grécia antiga, um mundo habitado e regido por deuses e deusas, entre as quais, Perséfone e Deméter, deusas agrárias, que eram homenageadas com jogos e competições inseridos nos cultos realizados por ocasião da primavera. 


\subsection{Considerações a respeito do handebol}

A ODISSÉIA (700 a. C), constitui-se como um dos maiores e mais antigos poemas épicos da literatura européia, fonte de grande influência sobre a literatura, 0 imaginário e o comportamento na Europa, de onde se originam as fontes de influências que vem marcar profundamente a cultura brasileira.

A epopéia narrada por Homero sobre os acontecimentos que sucedem aos heróis na viagem de retorno á pátria, também, traz evidências sobre a origem das modalidades esportivas praticadas com bola na Grécia Clássica. Na rapsódia VI Homero faz mençōes à jogos com péla, a bola, revelando a origem da prática de diversas modalidades esportivas com bola, como as que deram origem ao handebol.

SIMÕES (1996) destaca que o handebol recebeu várias denominaçōes no passado: hazena, handbold e torball. Atribui a origem desse esporte à Lídia, na Ásia menor, apoiado em referência a pesquisas arqueológicas em sítios na Grécia e Egito, que trouxeram à luz objetos e figuras, representando jogos com bola.

O handebol, na atualidade constitui-se como um jogo formado por duas equipes compostas por sete jogadores cada, que buscam por meio de passes de mão obter o gol.

Entre os esforços individuais necessários ao handebol, destaca-se a habilidade física, a força, a velocidade, a técnica no manejo da bola e o desenvolvimento de estratégias especificas (SIMÕES ,1987)

Para CERCEL (1980) ${ }^{2}$, citado SIMÕES (1987), as equipes esportivas representam um "micro sistema" social.

Para MOSQUERA e STOBAUS (1984) ${ }^{3}$, citado SIMÕES (1987) um "paradigma da vida humana distribuída em múltiplas minisociedades".

As concepções sobre o esporte como modelo que reproduz as relações de poder, crenças e comportamentos definidos no macro, caracteriza o handebol como uma minisociedade, mostrando que características psicológicas e comportamentais

\footnotetext{
${ }^{2}$ P. CERCEL, Balonmano: ejercicios para las fases del juego, Bucarest: Editorial Sport-turism, 1980.

3 J. MOSQUERA; C. STOBAUS, Psicologia do Desporto, Porto Alegre: Ed. da Universidade, 1984.
} 
inerentes a modalidade, podem circunscrever a ação em diversos setores da sociedade.

O handebol foi introduzido no Pais por imigrantes Alemães, aos 26 de fevereiro de 1940, foi fundada a Federação Paulista de Handebol, estado que abriga a CONFEDERAÇÃO BRASILEIRA DE HANDEBOL (2004), cujo primeiro presidente, foi o Professor Jamil André da Universidade de São Paulo

$\mathrm{Na}$ atualidade, o handebol, é um dos esportes coletivos mais praticados em todo o mundo, exigindo em princípio movimentos básicos como correr, saltar e arremessar, ganha complexidade num jogo entre duas equipes de sete jogadores cada, que buscam por meio de passes de mão e arremessos obter o gol.

A possibilidade de flexibilizar as regras e adaptar-se aos espaços nas escolas contribui para que o handebol seja apontando, como o esporte de maior preferência de meninas e meninos na escola pública (SIMÕES \& CONCEIÇÃO, 2004).

Desta forma, o ambiente escolar constitui a base principal de onde se formam dos quadros das equipes brasileiras de handebol masculina e feminina. Diferenciando este esporte das outras modalidades esportivas no Brasil, cujas bases, tradicionalmente se originam a partir dos clubes.

Evidenciando a ascensão do handebol no Brasil, as seleções brasileiras, feminina e masculina, obtiveram medalha de ouro nos jogos Pan Americanos de 2004, realizados em San Domingo, reunindo pela primeira vez na história desse esporte no Brasil as duas equipes nos Jogos Olímpicos 2004.

Entretanto, no que se refere ao desempenho das seleçōes masculina e feminina nos Jogos Olimpicos de 2004, não houve surpresas, pois das doze seleçōes do torneio masculino: Croácia, Alemanha, França, Espanha, Rússia, Hungria, Islândia, Grécia, Eslovênia, Egito, Coréia do Sul e Brasil, a seleção da Croácia, campeã mundial, consagrou-se pela sexta vez campeã olimpica, e a seleção brasileira masculina ficou em décimo lugar. No handebol feminino, dez seleçōes participaram do torneio: Dinamarca, Coréia do Sul, Ucrânia, França, Hungria, Espanha, Brasil, China, Grécia e Angola. A Dinamarca obteve a medalha de ouro e as brasileiras ficaram em sétimo lugar, avançando uma posição em relação a Sydney 2000 . 
Os resultados obtidos pelas equipes brasileiras de handebol nas Olimpiadas 2004 mostram que 0 fator sorte teve pouca influência nos resultados, o que demonstra a fragilidade das expectativas que se apóiam em expectativas de pautados com base nesse fator, evidenciando que os resultados no esporte são frutos da solidificação da cultura do esporte no Brasil, apoiada em um trabalho sistemático, embasado na estrutura física do atleta, habilidade, força, velocidade, técnica no manejo da bola, desenvolvimento de estratégias aplicadas em situaçōes especificas e na preparação psicológica das equipes, ressaltando-se que 0 emocional pode fazer diferença.

\subsection{A Psicologia do esporte}

$\mathrm{Na}$ atualidade, existe consenso entre os profissionais do esporte, sejam atletas, técnicos, cientistas do esporte, dirigentes e expectadores, que os aspectos mentais, adquirem cada vez mais importância no desempenho SEILER (1992) ${ }^{4}$ citado por SCHILLING e GUBELMANN (1998).

A eficiência no esporte tem sua sintese nos resultados obtidos nas Olimpíadas, acontecimento disseminador de novos paradigmas. Obviamente, o foco no treinamento de força, velocidade, flexibilidade, habilidade técnica e tática, são fatores importantes, porém, os aspectos comportamentais, além de ser os mais dificeis de serem desenvolvidos, é o que menos tem sido enfocado.

O equilíbrio emocional é um fator decisivo no esporte, tendo em vista que avançam as pressões e aumentam as expectativas, exemplo disso, são os resultados obtidos nas Olimpiadas, eventos disseminadores de novos paradigmas.

A auto-percepção relaciona-se à auto-eficacia, lócus de controle, estratégias de coping e atribuição das causas, delimitando o potencial de realização no esporte SINGER (1984) ${ }^{5}$ citado por SINGER e ORBACH (1999).

As concepções sobre a influencia dos aspectos psicológicos e motivacionais que se verificam na Europa e nos EUA da década de 80 aos dias atuais, mostram

\footnotetext{
${ }^{4}$ R. SEILER, Performance enhancement: a psychological approach. Sport Science Review, 1992.

5 R. N. SINGER,. Sustaining motivation in sport, Tallahassee: Sport Consultants International, 1984.
} 
que a preparação psicológica necessita ser efetivamente implementada no esporte brasileiro.

O exame das forças que influenciam as escolhas, a persistência e a realização no esporte e das estratégias de coping adotadas pelos atletas, apresentar-se-ia, como uma das vertentes mais modernas da psicologia do esporte, existindo uma grande escassez de trabalhos e pesquisas nesse campo no País.

O grande diferencial do atleta no esporte de alto rendimento não seria o aspecto fisico-motor, pois muita ênfase foi dada aos aspectos fisicos, para obtenção de força, resistência e flexibilidade. Portanto, haveria uma tendência ao nivelamento desses fatores no esporte de alto nivel técnico de desempenho, nos quais a preparação psicológica dos atletas conjugada com os aspetos físicos e táticos constituir-se-ia, como fator diferencial SCHILLING e GUBELMANN (1995).

No escopo desses trabalhos, destacam-se o estimulo ao diálogo interno positivo, a visualização intrínseca de uma atuação ideal, ou seja, fazer com que o atleta concentre-se no controle da situação, internalizar a segurança, focar no objetivo, ou seja, proporcionar ao atleta a aquisição de uma imagem mental positiva.

A visualização extrinseca do desempenho, cujo objetivo, é proporcionar ao atleta imagines mentais de sua atuação ideal, como se assistisse a um filme de si mesmo e, na seqüência, coloca em prática a ação imaginária. Entre os trabalhos desenvolvidos no campo da mentalização, incluem-se, também, técnicas de meditação, algumas vezes, associadas ao hábito de rezar, o que pode ser constado em imagens da seleção brasileira de futebol campeã no World Cup Korea-Japan 2002, veiculadas em cadeia mundial de televisão, fatos que suscitam muitas dúvidas e questionamentos com relação a essas práticas que, por vezes, se sobrepõem à intervenção psicológica, quando o psicólogo é substituido por lideres religiosos ou pais de santo que prestam assistência às equipes esportivas.

A religiosidade, as crenças e a espiritualidade dos atletas são questões de foro intimo, no entanto, dada a forma amalgamada com que esporte, religião $e$ "psicologismos" se apresentam, a questão assume relevância, não podendo ser relegada à intervenção leiga, merecendo ser analisada, segundo o enfoque científico, para reunir bases teóricas e epistemológicas que permitam a 
compreensão de fenômenos psicológicos e dinâmicos, sem perder de vista os objetivos do esporte.

No Brasil, a atuação dos psicólogos do esporte caracteriza-se pela intervenção pontual em momentos de crise, contrariando a tendência ao desenvolvimento de um trabalho de intervenção psicológica ao longo de um processo.

No Simpósio Internacional de Psicologia do Esporte BALAGUÉ (2001), afirmou que a preparação psicológica do atleta deve ser periodizada e o sucesso no esporte de rendimento não resultaria apenas como fruto das ações do atleta, especificamente, na competição esportiva, mas o alto desempenho seria obtido, apenas, pela periodização do treinamento, pelo estabelecimento de metas de curto, médio e longo prazos, desafiadoras e realistas, ao mesmo tempo; paralelamente a esse trabalho, o desenvolvimento de estratégias psicológicas para lidar com as ansiedades, considerando-se o equilíbrio entre aspectos fisicos e psicológicos

No Brasil, a psicologia do esporte encontra-se em fase de estruturação, e os trabalhos desenvolvidos no campo caracterizam-se pela intervenção apenas nas situaçōes de crise. No entanto, o quadro começa a se alterar, pesquisas realizadas por NERY (2002) chamam atenção para a importância dos aspectos fenomenológicos na subjetividade dos grupos esportivos, como fatores preponderantes na interação e coesão grupal.

\subsection{Lócus de Controle}

O lócus de controle é um conceito psicológico de grande difusão em nivel mundial. Em consulta realizada, em julho de 2003, à base de dados Web of Science, havia 2.091 citações bibliográficas em periódicos científicos internacionais com referência à tese de J. B. Rotter, Generalized Expectancies for internal vesus external control of reinforcement que apresenta a criação da escala de lócus de controle, traduzida no Brasil para a lingua portuguesa por DELA COLETA (1979). 
O lócus de controle pode ser caracterizado como as crenças que as pessoas possuem sobe a fonte de controle de seus comportamentos. LEFCOURT ${ }^{6}$ (citado por TAMAYO, 1989) pondera que os estudos sobre lócus de controle oscilam entre a perspectiva motivacional e a fenomenológica existencial, em que o sujeito não apenas explica mas, também, estrutura o seu destino. Mostrando que trata-se de um fenômeno que se insere nas esferas cognitiva, perceptiva e motivacional.

A revisão das bases teóricas que originaram o conceito de lócus de controle contribui para ajudar a dimensionar esse construto, oriundo da teoria da aprendizagem social, uma abordagem teórica que busca integrar conhecimentos de diferentes correntes psicológicas.

ROTTER, CHANCE e PHARES (1972) concebem o lócus de controle, como um conceito unidimencional - lócus de controle interno $x$ lócus de controle externo, que assumem, posteriormente, um caráter multidimensional nos estudos realizados por LEVENSON (1973), por meio das análises fatoriais dos itens que compõem a escala de J. B. Rotter, encontrou uma segunda dimensão ao lócus de controle externo, subdividindo-o em lócus de controle externo acaso (sorte-azar) e lócus de controle externo pessoas poderosas (autoridades e figuras de poder), criando sob o enfoque desses conceitos 0 instrumento denominado Multidimensional Locus of Control in Psychiatric Patients, traduzido para a língua portuguesa por DELA COLETA (1987) com o titulo de "Escala multidimensional do lócus de controle de Levenson".

$\mathrm{Na}$ literatura, há uma polêmica em torno dos conceitos de unidimensionalidade e multidimensionalidade do lócus de controle; no entanto, entre a maioria dos pesquisadores existe um determinado consenso de que as pessoas $\mathrm{e}$ as organizações com orientação ao lócus de controle interno estariam mais propensas a atingir metas e objetivos.

O lócus de controle seria um fator importante no esporte, os atletas com orientação ao lócus de causalidade interna teriam maior facilidade para captar os aspectos relevantes de uma situação, saberiam efetivamente o que fazer, estando

\footnotetext{
${ }^{6}$ H. M. LEFCOURT, Research wirh the locus of control construct: assesment methods, New York: Academic Press, 1981, v.1.
} 
de modo mais habitual envolvidos em situaçōes apropriadas e tenderiam a obter com mais freqüência sucesso em suas ações (SINGER, 1999).

Por outro lado, atletas que orientariam suas ações pelo lócus de controle externo, estariam mais propensos ao insucesso, alinhando-se a um grupo de pessoas que se caracterizariam por atribuir a responsabilidade sobre aquilo, que Ihes sucede: a sorte, azar, figuras de poder e ou autoridades.

Aqui cabe uma reflexão sobre o impacto fenomenal que a dimensão sorteazar apresenta no esporte brasileiro. Nas olimpiadas de Atenas 2004 tornou-se célebre a frase "Zeus é brasileiro", analogia à máxima do cotidiano "Deus é brasileiro", provérbio que evidência de maneira profunda uma verdade, revelando como a dimensão externa sorte-azar enraíza-se na cultura, persistindo a esperança de que tudo vai dar certo, mesmo que, efetivamente, não se tenha feito muito para isto. Um fato que gera preocupações dada a grande importância do esporte no País, impactando com políticas ao esporte, voltadas a descoberta de talentos em detrimento de sua formação.

O lócus de controle externo seria um traço de personalidade pouco favorável no esporte de rendimento, de acordo com Robert N. Singer, chefe do Departamento de Ciência do Esporte e do Exercício da Universidade da Florida e ex-presidente da International Society of Sport Psychology, atletas com orientação para o lócus de controle externo comportar-se-iam como "peões em um tabuleiro de xadrez"

No Brasil, existem poucos estudos envolvendo o lócus de controle no esporte, tendo sido apenas encontradas referências a um trabalho desenvolvido por VASCONCELLOS e DE ROSE (1991) a respeito de uma análise realizada sobre o espirito competitivo, pressão de tempo, capacidade de decidir rapidamente e exigência de sucesso, feito com a Seleção Brasileira Feminina de Basquete, ouro nos jogos Pan-americanos de Havana em 1991, cujas perspectivas conclusivas citam que o "self" justificaria $75 \%$ do sucesso ou insucesso das atletas.

BIDDLE e HANRAHAN (1998) em avaliação de escalas de lócus de controle desenvolvidas para a área do esporte e exercício, fazem restrições à instrumentos de mensuração do lócus de controle, definidos dentre de uma perspectiva teórica limitada, entre os quais, a Fitness Locus of Control Scale (FITLOC) de Whitehead \& Corbin (OSTROW, 1996), Exercise Objetives Locus of Control Scale (EOLOC) de 
Mc Cready \& Long (OSTROW, 1996) ${ }^{7}$. Entre os problemas verificados por (BIDDLE \& HANRAHAN, 1998) em testes de aplicação prática com os instrumentos, verificou-se tendência para valores muito elevados de lócus de controle interno.

Uma outra explicação para os problemas verificados, pelos autores citados anteriormente, em relação aos estudos empíricos realizados com as escalas de lócus de controle, além da falta de bases teóricas, seria praticamente a inexistência de pesquisas envolvendo aspectos qualitativos nesta área.

Tendo em vista a necessidade de se compreender as bases teóricas, nas quais se apóiam os conceitos que originaram as escalas de lócus de controle, a seguir são feitas considerações sobre a teoria da aprendizagem social.

A Teoria da Aprendizagem Social propõe-se a um grande desafio: compreender o homem e prever seu comportamento em ambientes relativamente complexos. ROTTER, CHANCE e PHARES (1972), nesse sentido, buscam ampliar e integrar correntes psicológicas distintas, consideradas limitadas quando vistas em separado; metaforicamente, as correntes psicológicas poderiam ser associadas como lentes coloridas, com as quais busca-se apreender a realidade.

O sentido desta analogia se estabelece na percepção, em torno da realidade pela Teoria da Aprendizagem Social, como uma fotografia colorida, obtida pela sobreposição de imagens captadas com lentes de diferentes cores.

A Teoria da Aprendizagem Social busca integrar os conhecimentos do behaviorismo e da psicanálise, sob a concepção de que o comportamento humano não poderia ser impulsionado apenas pela busca de respostas seletivas, sob o efeito de reforços anteriores (lócus de controle externo), conforme as definições dos cânones clássicos do behaviorismo (FERSTER,CULBERSTSON \& PERROTT, 1978). Nem tão pouco, tal comportamento seria previsível pautado na generalização de testes feitos com animais em laboratórios, tidos como precários para prever o comportamento humano.

A atmosfera científica da qual se originou a Teoria da Aprendizagem Social, girava em torno da psicologia clínica bastante influenciada por $S$. Freud e a

\footnotetext{
${ }^{7}$ Instrumentos em fase de estudo pelo pesquisador
} 
polarização em torno das idéias de A. Adler (CALIFORNIA STATE UNIVERSITY, 2003).

Alfred Adler enfatizou aspectos biológicos, culturais e sociais na constituição da personalidade dos indivíduos, associando à psicologia idéias decorrentes dos avanços emergentes da sociologia e da antropologia em oposição ao tom naturalista e instintual da psicanálise - personalidade moldada por instintos inatos, pela busca do prazer, satisfação dos desejos, necessidades e temores inconscientes em vista dos quais o ser humano comportar-se-ia como "naïven

A. Adler concebe a agressividade e o desejo pelo poder, mais importante que a sexualidade, considerando a personalidade, moldada por circunstâncias sociais $e$ por fatores biológicos, atraindo seguidores em todo 0 mundo e influenciando de forma marcante a psicologia social americana (HALL, LINDZEY \& CAMPBELL 2000, p. 124).

Inicialmente, A. Adler considerou a personalidade orientada por impulsos voltados à superação de supostos sentimentos de inferioridade, os quais, se evidenciariam no estilo de vida adotado pelas pessoas, cujos objetivos latentes seriam a compensação dos sentimentos de menos valia. "O estilo de vida é uma compensação de uma inferioridade particular. Se a criança é particularmente frágil, seu estilo de vida assumirá as formas de fazer aquelas atividades que produzirão força física" (HALL, LINDZEY \& CAMPBELL 2000, p. 124).

Estes impulsos manifestar-se-iam como uma espécie de "protesto masculino", em compensação à sentimentos de inferioridade, associados a falta de virilidade ou feminilidade do homem. Caracterizando aquilo que C. G. Jung caracterizou como conflito com a anima ou manifestação de aspectos negativos da anima decorrentes da não integração dos conteúdos do si-mesmo ao self.

Posteriormente, Adler reformulou a teoria da inferioridade, associando-a à sensação de incompletude ou imperfeição em qualquer esfera da vida e atribuindo ao sentimento de inferioridade uma possibilidade de melhora na condição humana. Finalmente chegando ao conceito de Self criativo, principio ativo e harmonizador da vida humana, fonte de energia e criatividade, fenômeno que agiria dando sentido e significado a vida, devolvendo aos individuos a noção de que poderiam ser os senhores e não vitimas do destino HALL, LINDZEY e CAMPBELL (2000). 
O conceito de Self criativo de Adler comporta um sentido existencial, que o aproxima-se do conceito de alma, e ao conceito de Inteligência Espiritual de ZOHAR e MARSHAL (2000), pois o vazio existencial das pessoas bem sucedidas seria fruto de um afastamento dos principios, que dão um sentido ordenador à vida, cuja busca de sentido seria uma das principais motivações da vida do homem e, essa procura tornaria as pessoas em criaturas espirituais.

As idéias de Adler exerceram influência na criação da Teoria da Aprendizagem Social de J. B. Rotter, na qual, o homem é visto, como um ser mais complexo do que qualquer artefato tecnológico que possa ser produzido.

No âmbito da Teoria da Aprendizagem Social o comportamento é visto de forma ampla, incluindo aspectos observáveis, como: escolher, correr, saltar, sorrir, tremer, bater, entre outros e os considerados implícitos, ou indiretamente observáveis, como os mecanismos de defesa: projeção (atribuir aos outros as dificuldades e limitações próprias); racionalização (tentativa de justificar o comportamento, segundo desculpas infundadas, distorcidas pela percepção subjetiva da realidade); deslocamento (dirigir ações agressivas para objetos seguros) entre outros.

Ao sintetizar as concepções em torno de comportamento potencial (CP), ROTTER, CHANCE e PHARES (1972) propõem um modelo matemático preditivo da possibilidade de ocorrer um determinado comportamento em dada situação especifica, definida, segundo a expectativa (Ex), o valor do reforço (VRa) e a situação psicológica (S1) como aparecem demonstrados na formulação lógica matemática dos conceitos em torno da Teoria da Aprendizagem Social apresentada a seguir:

\section{$\mathrm{PCx}, \mathrm{S} 1, \mathrm{Ra}=f(\mathrm{Ex}, \mathrm{Ra}, \mathrm{S} 1 \& \mathrm{VRa}, \mathrm{S} 1)$}

O comportamento potencial é interpretado da seguinte forma: se um determinado comportamento ocorrer (PCx) em uma dada situação psicológica (S1) em relação a um determinado reforço $(R a)$, será função $(f)$ da expectativa $(E x)$ do reforço acontecer (Ra) na situação psicológica (S1) \& do valor do reforço VRa nessa situação psicológica (S1). 
A expectativa do reforço $(E x)$ é um valor subjetivo (do qual se origina o conceito de lócus de controle) que se refere à crença, grau de confiança ou probabilidade imaginada pela pessoa de que agindo ou comportando-se de certa forma, irá conseguir obter determinado reforço.

Assim, constitui-se em algo independente do valor ou da importância dos reforços (satisfação, prêmios e ou vantagens obtidos ao vencer uma determinada competição esportiva, por exemplo), estaria associada às experiências passadas (número de vitórias ou recordes obtidos no esporte, por exemplo).

No entanto, seu componente subjetivo não permite que seja calculada, simplesmente, como uma fórmula relativa ao número de ocorrências no passado conforme citam ROTTER, CHANCE e PHARES (1972, p. 21), a expectativa tem um peso maior em situações novas, por exemplo, a expectativa de um atleta aspirante vencer uma determinada prova esportiva, seria bastante influenciada por suas experiências passadas, generalizadas do envolvimento em diversas situações esportivas. Entretanto, após um determinado número de participaçōes, a expectativa do atleta passa a ser marcada pelas experiências mais recentes, obtidas na modalidade especifica em que atua, na qual as vivencias passadas exercem apenas uma influência relativa sobre a expectativa de obter sucesso.

Para, ROTTER, CHANCE e PHARES (1972), a expectativa de obter um reforço em virtude de um comportamento específico deve ser considerada não apenas pela natureza ou importância do reforço; por exemplo, a expectativa dos atletas brasileiros conseguirem uma medalha de ouro nas olimpiadas seria baixa, em decorrência da influência de um quadro histórico de poucas medalhas, de tal forma que, ao se classificarem nos jogos Pan-Americanos, os atletas comemorariam como se tivessem conquistado o ouro na olimpiada, tendo em vista antecipar o reforço e amenizar possiveis sentimentos de frustração.

Em conseqüência destas expectativas, acabariam mobilizando-se menos nos treinamentos, pois a simples participação passaria a ser o objetivo, ao passo que atietas com as mesmas características físicas e táticas, mas com um quadro referencial de expectativa diferente mobilizar-se-iam mais e acabariam vencendo.

Em relação ao valor de um determinado reforço (VRa), os individuos seriam diferenciados de acordo com o valor que atribuem a estes reforços. O valor do 
reforço é uma variável dependente na determinação do potencial de ocorrência de um comportamento, por exemplo, obter sucesso em uma competição esportiva.

Conforme os autores, o valor do reforço é subjetivo, e tudo aquilo que desejamos que aconteça, e as coisas pelas quais nos sentimos atraidos, possuiriam um alto valor de reforço, portanto, esse valor comporta uma carga subjetiva, referindo-se ao grau de preferência de que um determinado reforço pode ocorrer .

Outra característica importante do valor do reforço seria sua interdependência relativa à expectativa de uma seqüência de reforços posteriores para sua obtenção, por exemplo, ganhar uma medalha olimpica, para certo atleta poderia implicar obtenção de outros reforços subseqüentes, como conseguir contratos para associar sua imagem à divulgação dos produtos, o que, conseqüentemente, levará a outros reforços e, assim, por diante.

As expectativas pessoais dos atletas quanto ao valor reforço implicariam que dois atletas que valorizam igualmente suas metas e objetivos teriam comportamentos distintos, de acordo com suas expectativas em relação ao valor do reforço.

Outro componente determinante na avaliação do comportamento potencial, é a situação psicológica, caracterizada pela forma particular como cada indivíduo percebe o ambiente, de modo que haveria sempre maior probabilidade de uma pessoa apresentar um comportamento específico (obter sucesso, por exemplo), em determinada situação psicológica do que em outra.

A idéia de situação psicológica confere à Psicologia do Esporte certo grau de importância, retificado pela necessidade de se identificar, caracterizar e trabalhar aspectos psicológicos relativos às expectativas e à percepção do ambiente por parte dos atletas e das equipes esportivas, conforme demonstrado no âmbito da Teoria da Aprendizagem Social sob o conceito de comportamento potencial.

No contexto dos conceitos envolvidos na determinação do comportamento potencial, surgiu o lócus de controle que, embasado na idéia de expectativa, define classicamente o lócus de controle como: a expectativa geral do controle do reforço interno $x$ externo. De tal modo, que o conceito de comportamento potencial possibilita o dimensionamento das potencialidades, aplicação e uso no esporte do lócus de controle. 


\subsection{As crenças religiosas por J. B. Pratt}

Envolvendo os diferentes dominios de crenças religiosas, incluindo-se, aquelas tidas como crendices e superstições, delimitando uma área de interesses constantemente realçada pelas pessoas, sem fazer uma distinção muito clara dos conceitos entre eles. A mescla formada pela fusão entre as crenças religiosas e o esporte suscita uma série de fatores positivos e negativos (HIGGS, 1996).

As questões formuladas nesse estudo, referem-se à influência dos diferentes dominios de crenças religiosas sobre o lócus de controle, a atitude e o relacionamento dos atletas.

Refletir e avaliar as condições que caracterizam as condutas e as atitudes no esporte de rendimento não são tarefas simples, levam-nos a avaliar os fenômenos psicossociais, sociodinâmicos e institucionais que influenciam decisivamente nas mudanças de comportamento, SIMÕES (2003).

A busca da compreensão do problema levou ao desenvolvimento do "Inventário Pratt de crenças religiosas no esporte".

As concepções estabelecidas na literatura científica por Norberto de Abreu e Silva, FREITAS (2002), PRATT (1907,1923), mostram que as crenças religiosas caracterizar-se-iam em quatro dimensões, conforme a natureza particular dos conceitos, das idéias e representações a respeito de como o espírito humano concebe, percebe, sente e usa a idéia de Deus. Fundamentado nas pesquisas empíricas realizadas nos últimos cem anos com o "Questionário Pratt de Crenças Religiosas", quatro modalidades de crenças religiosas: primitiva, intelectual, emocional e ético-moral, apresentadas a seguir.

Crença primitiva, uma atitude religiosa que se manifestaria naturalmente ao ser humano, uma credulidade espontânea, fruto de uma herança, poderia ser caracterizada como uma manifestação do arquétipo, que adquire representações por meio dos símbolos culturais, transmitidos pelas tradições familiares e comunitárias. Constituir-se-ia como a crença original da maioria das pessoas, cujas representaçōes remeteriam aos símbolos disponibilizados no ambiente, aos usos, costumes, ritos e figuras de autoridade. Uma modalidade de crença que se manteria 
na vida adulta, como que por inércia ou porque a pessoa se acostumou a agir e pensar, de acordo com determinados moldes, sem questioná-los.

Marcada, algumas vezes, pela percepção indiferenciada entre imaginação e realidade, poderia ser identificada como uma atitude religiosa naif, dada a aceitação sem questionamentos de tudo que é percebido pelos sentidos, podendo ser, também, definida como crença perceptiva, pela aceitação sem críticas das imagens (PRAT, 1907).

Crença intelectual, um tipo de atitude religiosa que se guia única e exclusivamente pela razāo, que se traduz como uma tentativa de se aproximar dos mistérios pela reflexão e experiência verificável.

Modalidade de crença religiosa que surgiria, após sucessivas crises, nos moldes da crença primitiva, seria o ceticismo que se instala, permeando o conflito entre crença e descrença no objeto primário.

A crença intelectual é marcada pela busca do objeto original perdido, pela necessidade de comprovação, evidências científicas, conceitos intelectuais, definições abstratas, necessidade e uso de Deus.

Apesar do rompimento com os conceitos primários, adquiridos pela intermediação de figuras de autoridade, como a crença primitiva, também se apoiaria em figuras de autoridade.

... Não há homem capaz de investigar mais do que uma porção infinitesimal de seu universo, por isto todos nós necessariamente e com razão aceitamos a maioria dos fatos - especialmente os científicos e históricos, segundo a versão dos especialistas...

PRATT (1907, p.39)

A não-materialidade (ausência da imagem) confere menos força a esta modalidade de crença; no entanto, sua natureza intangivel dar-lhe-ia maior estabilidade, conceitos abstratos, dificeis de serem relacionados entre si, também, dificeis de serem suplantados.

Crença emocional, atitude religiosa que se apoiaria no sentimento vital, na sensação de estar vivo, desdobrando-se em vivências de fundo emocional.

${ }^{8}$ Tradução: Paulo Felix Marcelıno Conceiçăo 
Um sentimento religioso que se traduziria na sensação de união com o divino, conexāo com Deus ou com a natureza, percepção de Deus como energia.

Crença religiosa, que se evidência no discurso de todas as pessoas, tidas como misticas, ao longo de toda a história da humanidade, e em convicções religiosas que se fundamentam na emoção, na percepção de Deus como energia e força da natureza (PRATT, 1907).

Uma modalidade de fé muito intensa experimentada em sensações corpóreas, poderia ser caracterizada como uma experiência psicossomática, que se manifestaria como uma expressão do arquétipo, sem representação mental, intermediada apenas pela emoção e suas correspondentes manifestações somáticas, as quais podem ser despertadas ou intensificadas, por meio de imagens, música, hinos, mantras recitados em cadencia hipnótica, tambores em ritmo frenético.

Assim como a crença primitiva, a crença emocional, por não possuir representação, também, escaparia a crítica.

Crença ético-moral, caracterizada pela consciência dos grandes valores da humanidade, valorizaria a atitude, aquilo que deve ser feito, a coisa certa e não necessariamente o sentimento. Uma modalidade de crença branda, diante da intensidade e dos excessos da crença emocional. A moral no que concerne ao espírito do homem e a ética compreendida como filosofia da moral, que se embasa na tetralogia do comportamento ético humano, do respeito mútuo, do diálogo, da justiça e da solidariedade, comportando valores que, também, são expressos pelo ideal olímpico. O poder de comunicação das metáforas, crença que se apóia na reflexão, orientação básica à vida abstraida dos mitos religiosos, considerados como alegoria, a busca do significado oculto, aquilo que em grego denomina-se como hypónoiai (BRANDÃO,1998).

J. B. Pratt deixa transparecer o sentido da dimensão ético-moral no título de sua obra The Religious Consciousness (PRATT,1927), denotando uma atitude reflexiva, ligada a consciência, no entanto, deixa claro que ética e religião, por vezes, assumem posiçōes distintas, e em outros, quase inseparáveis. 
AMES $^{9}$ citado por PRATT (1923), faz considerações a respeito de conotações negativas que o termo moral pode assumir, pela imposição de modos de ser, agir e formas de pensar, inferindo que por vezes, o homem religioso pode comportar-se de forma imoral, e um homem moral possa ser irreligioso.

Crença marcada pelo formalismo, traz implicita a suposição de que o ser humano seria incapaz de estabelecer por suas próprias convicçōes um conjunto de regras e leis morais para atingir uma suposta perfeição necessária, arbitrando as relações que se estabelecem entre necessidade e desejo.

Pela busca de uma cultura ético-moral, a sociedade teria muitas ramificações, não se restringindo apenas às religiōes cristãs, podendo ser verificada, até mesmo, em sistemas tidos como não-religiosos, tal como o budismo que buscaria imprimir à vida não só um estilo e, sim, uma atitude diligente, zelosa e consciente em relação ao universo e às suas leis - o karma, como forma prática de enfrentar o sofrimento, (PRATT, 1923).

A revisão de literatura procurou ressaltar a relevância psicológica da temática envolvida em torno dos conceitos lócus de controle e crenças religiosas, numa interrelação caracterizada no âmbito desta dissertação sob a denominação perfil Perséfone, em analogia a um símbolo cultural disponibilizado pelo eixo grecoromano da cultura, referencial que oferece uma série de conteúdos simbólicos a psicologia do esporte. Mas a vista do que foi exposto até o momento, em relação à esporte, espiritualidade, crenças religiosas e lócus de controle suscitam-se uma série de questionamentos:

- Será que as crenças religiosas estabelecidas nos parâmetros primitivos, intelectual, emocional e ou ético-moral inserem-se no esporte, apenas como uma espécie de uso ou fuga diante de dificuldades e desafios constantes que são vivenciados pelos atletas, caracterizando uma atitude antiesportiva conforme afirma KREIDER (2003), inferindo um lócus de controle orientado pelo externo?

- Será que se caracterizariam, simplesmente, como atitudes antiéticas, conforme VOLKWEIN (1995), ou dada à complexidade do fenômeno, sua natureza pessoal, particular e indissociável do comportamento dos atletas, aspectos relativos ao

${ }^{9}$ The psychology of religious belief, 
problema deveriam ser enfocados apenas sob a perspectiva de conceitos psicológicos, como o lócus de controle?

- Será que a religião insere-se no esporte sob um enfoque mais orientado para a crença ético-moral, representando um movimento em direção ao resgate de valores, ao mesmo tempo em que afastaria, "naturalmente", os atletas de comportamentos incompativeis com o esporte de alto rendimento.

- Será que, por vezes, a insólita associação entre esporte e religiosidade nos dias atuais não poderia se estabelecer como um modelo de estímulo à saúde, alinhandose a conceitos mais amplos, como os estabelecidos pela OMS de estímulo às práticas saudáveis, equilibrio entre saúde física e psíquica, desde de que assegurado o lócus do controle interno dos atletas?

\section{HIPÓTESES DESCRITIVAS}

\subsection{Hipóteses centrais}

- Os comportamentos adotados pelos atletas de handebol nas equipes feminina e masculina são embasados em um referencial psicossociológico de tomada de decisão que se define como lócus de controle interno, externo sorte-azar e pessoas poderosas.

- A espiritualidade e os sentimentos de religiosidade dos atletas de handebol são definiveis pelas crenças religiosas: primitiva, intelectual, emocional e éticomoral, conforme as representações dos atletas sobre a figura de Deus, e de suas percepções a respeito da interferência divina no meio esportivo.

- O referencial de tomada de decisão envolvido pelos atletas de handebol, de ambos os sexos, pelo lócus de controle interno, externo sorte-azar e pessoas poderosas associados aos sentimentos de religiosidade desses atletas, definidos pelas crenças religiosas primitivas, intelectual, emocional e éticomoral delimitam um perfil psicológico de comportamento dos atletas. 


\subsection{Hipóteses complementares}

- O lócus de controle interno e externo varia de acordo com o referencial de controle assumido pelos atletas em suas tomadas de decisão, oscilando em conseqüência das percepções que possuem sobre a causa dos eventos que sucedem no meio esportivo, decorrentes de suas próprias ações, creditadas à sorte, quando vencem, ao azar quando perdem ou à influência de pessoas poderosas: árbitros e técnicos entre outras.

- A espiritualidade e a religiosidade dos atletas comportam caracteristicas psicológicas, a crença primitiva associada aos arquetípicos, a intelectual associada com conflitos, a emocional à somatização e reações fisiológicas, e a crença ético-moral pela busca da integração do Self.

\subsection{Hipóteses estatísticas}

Ho Hipótese de nulidade - Não há diferença estatisticamente significativa entre as variáveis sociotécnicas (posição ocupada pelo atleta equipe, sexo, faixa etária, grau de escolaridade, naturalidade) e o lócus de controle interno, lócus de controle externo sorte-azar, lócus de controle externo pessoas poderosas e as modalidades de crenças religiosas primitivas, intelectuais, emocionais e morais.

$\mathrm{H}_{1}$ Hipótese alternativa - Há diferença estatisticamente significativa entre as variáveis sociotécnicas (posição ocupada pelo atleta equipe, sexo, faixa etária, grau de escolaridade, naturalidade) e o lócus de controle interno, lócus de controle externo sorte-azar, lócus de controle externo pessoas poderosas e as modalidades de crenças religiosas primitivas, intelectuais, emocionais e morais. 


\section{DELIMITAÇĀO DO ESTUDO}

O presente estudo delimita-se à pesquisa das opiniões dos atletas de handebol de equipes masculinas e femininas, maiores de 18 anos, atuantes no esporte de alto nivel de rendimento e desempenho, aos dados coletados empregando-se o Inventário Pratt de crenças religiosas no esporte e a Escala multidimensional do lócus de controle do esporte, visando a validação desses instrumentos e a busca de dados científicos que favoreçam a compreensão das relações entre características sociotécnicas, lócus de controle e crenças religiosas dos atletas de handebol, de acordo com modelo experimental e teórico pautado na obras de J. B. Pratt.

Este estudo foi submetido à avaliação do Comitê de Ética da Escola de Educação Física e Esporte da Universidade de São Paulo (ANEXO I), estando em conformidade com a Portaria n $196 / 96$ do Conselho Nacional de Saúde.

\section{CASUISTICA}

A pesquisa foi embasada no método exploratório, do tipo de pesquisa descritiva, tendo por objetivo analisar as possíveis relações entre variáveis sociotécnicas, crenças religiosas e lócus de controle de atletas de handebol. A coleta de dados foi feita, utilizando-se dois instrumentos, um protocolo de avaliação das crenças religiosas dos atletas e uma escala multidimensional do lócus de controle do esporte, que são validados nesse estudo.

\subsection{Sujeitos}

Fizeram parte do presente estudo 111 atletas de handebol do mais alto nivel técnico do Brasil , 53 do sexo feminino e 58 do sexo masculino, com idade variando entre 19 e 38 anos, atuantes nas competições realizadas pela liga nacional nas cidades de São Paulo e Grande São Paulo e em nivel internacional pelas seleções brasileiras feminina e masculina. 


\subsection{Procedimentos da pesquisa}

Primeiramente, estabeleceu-se contato telefônico com os técnicos e responsável pelas equipes, agendada uma reunião para esclarecimentos sobre os objetivos do trabalho e obtenção do consentimento dos técnicos (ANEXO III).

Em seguida, foi feito o contato com os atletas, para os esclarecimentos sobre os objetivos da pesquisa e obter consentimentos (ANEXO II)

Os atletas foram orientados sobre o preenchimento dos instrumentos, assegurado-Ihes o direito de desistirem da pesquisa a qualquer momento sem necessidade de explicações, conforme os termos do consentimento livre e esclarecido, que aconteceu em dois casos, um atleta que não preencheu a escala multidimensional do lócus de controle e outro que desistiu quando começou a preencher o Inventário Pratt de crenças religiosas no esporte.

\subsection{Coleta de dados}

Os dados foram coletados pelo próprio pesquisador nas dependências de clubes sociais, ginásios e estádios, utilizando-se salas de treinamento, vestiários, quadras e arquibancadas. Os instrumentos foram aplicados coletivamente, em grupos, variando entre seis e 18 atletas, de acordo com as disponibilidades em campo sob a perspectiva de proporcionar condições apropriadas à pesquisa.

Após o preenchimento da escala multidimensional do lócus de controle do esporte, em seguida, os atletas responderam ao Inventário Pratt de Crenças Religiosas no Esporte, sem interferência do pesquisador ou de terceiros. As dúvidas que surgiram foram sanadas individualmente, no geral, os atletas mostraram-se prestativos e atenciosos, não encontrando dificuldades para completar os instrumentos.

\subsection{Análise dos dados}

Os dados obtidos foram digitalizados em um computador com processador Intel x86 Familia 6 Modelo 8 Nivel 6 128,0 MB RAM com sistema operacional 
Microsoft Windows 98, e analisados no programa SPSS versão 10.0, SPSS INC, 1989 - 1999, USA para procedimentos de estatística descritiva e o estabelecimento de medidas de posição, dispersão, desvio-padrão, valores minimos, máximos e as medianas das variáveis continuas: idade, sexo, posição, escores de lócus de controle - lócus de controle interno ( $\mathrm{LCl}$ ), lócus de controle externo pelo caso (LCE A) e lócus de controle externo pessoas poderosas (LCE-PP).

Em uma segunda fase, foram analisados no SAS (Statistical Analysis System), versão 6.12. SAS Institute Inc, 1989-1996, Cary, NC, USA para análise da consistência interna da escala multidimensional do lócus de controle, análise fatorial e associação entre lócus de controle e crenças religiosas e cálculos das diferenças entre as médias pelo teste de post-hoc de Turkey.

\subsection{Desenvolvimento dos instrumentos de pesquisa}

Nesta pesquisa, os instrumentos utilizados, foram desenvolvidos no âmbito do próprio trabalho, objetivando implementar no cenário do esporte brasileiro, uma escala de lócus de controle e um inventário de crenças religiosas, tendo em vista comprovar as hipóteses levantadas.

Um dos problemas mais comuns em ciência é a generalização, pois os resultados encontrados em uma área devem ser vistos com cuidado quando extrapolados a outras. $O$ mesmo pode-se dizer em relação aos instrumentos de pesquisa, desenhados para aplicação em uma área ou campo específico da ciência, deveriam ser adaptados e validados quando aplicados em outros campos.

\subsubsection{O Inventário de crenças religiosas no esporte (ICRE)}

O instrumento, inicialmente, sob a denominação Inventário de crenças religiosas no esporte, foi adaptado à área do esporte pelo pesquisador pautado nas pesquisas realizadas com $\circ$ Questionário Pratt sobre Crenças Religiosas PRATT (1907,1927), FREITAS (2002), constituindo-se em uma série de questões, formuladas a princípio com o propósito de pesquisar as crença religiosas de figuras ilustres nos campos académico e religioso, no contexto da época de sua criação, 
contou com a participação de Willian James, entre os seus respondentes, expoente da psicologia da religião nos Estados Unidos.

Em 1998, foi traduzido no Brasil pelo Professor Norberto de Abreu e Silva como conteúdo especifico de uma disciplina que abordava questões relativas à experiência religiosa e a psicopatologia no Instituto de Psicologia da Universidade de Brasilia (UCB). Posteriormente, foi adaptado por FREITAS (2002) em tese de doutorado intitulada "Crença Religiosa e a Personalidade em Estudantes de Psicologia - Um Estudo por meio do Questionário Pratt e do Método de Rorschach".

No Brasil, a tradução e a adaptação do instrumento conservou as mesmas caracteristicas gerais delineadas por PRATT (1907) em torno de uma metodologia de enfoques fenomenológicos e reflexivos, que são evidenciados nas pesquisas realizadas por FREITAS (2002), que se manteve fiel aos pressupostos teóricos de PRATT, conservando no instrumento a forma típica de articulação das questōes, geradoras de ansiedade, ou alto grau de mobilização como afirma a autora nas paginas 119 e 172, no entanto, ressaltada a importância dessa estratégia no âmbito da pesquisa fenomenológica.

Seguindo esta linha, a pesquisadora apresentou o inıstrumento aos sujeitos de seu estudo (alunos voluntários do curso de psicologia) na forma de uma lista contendo dez questões sem espaços para resposta, a serem respondidas pelos estudantes por seus próprios meios no prazo de uma semana.

FREITAS (2002) observou que a experiência de responder o questionário Pratt de crenças religiosas gerava ansiedade e confusão nos sujeitos, o que foi manifesto verbalmente pelos estudantes em entrevistas posteriores, o que também refletiu em questões deixadas em branco ou em respostas secas. Apesar disso, a autora constatou que os voluntários sentiram-se satisfeitos em participar da pesquisa, pelo fato de proporcionar uma reflexão sobre questões, usualmente, pouco pensadas, o que resultaria em um crescimento pessoal, segundo os depoimentos dos respondentes registrados pela pesquisadora.

Porém diante das questōes que se formularam em torno do questionário Pratt de crenças religiosas em relação à metodologia, aspectos formais e estruturais, pressupõe-se uma série de dificuldades e limitações para a aplicação do instrumento na área do esporte de competiçäo e desempenho, um meio dinámico que busca 
conhecimentos que possam resultar em propostas de trabalho e intervenções nas questōes de natureza psicológica limitantes ou impulsoras do rendimento físico, técnico e ou tático dos atletas.

\subsubsection{Primeira fase de desenvolvimento do Inventário de crenças religiosas no esporte: validação por especialistas}

O pesquisador elaborou um protótipo apoiado no questionário Pratt de crenças religiosas, inserindo campos com espaços formatados para as respostas e substituindo alguns termos por sinônimos (FERREIRA, 1995) a fim de simplificar a linguagem e adequá-la ao esporte.

Implementadas estas modificações, o instrumento foi previamente testado entre os membros do laboratório de pesquisa ao qual o pesquisador é vinculado Grupo de Estudos e Pesquisas em Psicossociologia de Esporte (GEPPSE), vinculado ao Laboratório de Estudos em Psicologia do Esporte (LAPSE) da Escola de Educação Física e Esporte da Universidade de São Paulo (EEFE-USP).

No pré-teste, o pesquisador constatou, assim como FREITAS (2002), que as questões delineadas em torno do questionário Pratt mobilizaram muito os respondentes, de modo que, um dos membros do GEPPSE precisou de quase três horas para responder as dez questões, visivelmente incomodado.

Diante destas perspectivas, o pesquisador recorreu à estratégia dos juízes. $O$ instrumento, inicialmente denominado questionário Pratt de crenças religiosas no esporte (APÊNDICE I), foi enviado para cinco juizes de diferentes áreas, dos quais, apenas quatro responderam (APENNDICE II), pois um dos juizes teve problemas de saúde, de tal forma que, foi avaliado por uma psicóloga especialista em técnicas de exames psicológicos, um psicólogo com experiência na esporte, uma socióloga e uma pedagoga.

A principio, não houve concordância entre os juizes quanto à clareza e adequação das instruções do instrumento. As principais criticas e sugestões formuladas são apresentadas a seguir:

- Excesso de itens.

- Pouco espaço destinado às respostas. 
- Formulação de diversas questões sob um único enunciado.

- Sequência de formulação das questões inapropriadas, denotando a sensação do entrevistado estar sendo testado de forma agressiva.

- Questōes envolvendo aspectos relativos a convicções e sentimentos que podem ter diferentes interpretações, de acordo com os valores e crenças de cada participante da pesquisa.

Neste processo de avaliação, também, foi solicitado aos juizes (APÊNDICES III, IV, V e VI). que formulassem criticas e sugestões quanto ao conteúdo especifico das questōes. As principais críticas e sugestōes ao conteúdo do instrumento, originalmente, apresentado, são delineadas nos dados do QUADRO 1.

\section{QUADRO 1 - Avaliaçāo dos juizes sobre o conteúdo das questōes do "Inventário de crenças religiosas no esporte": primeira fase.}

\begin{tabular}{|c|c|c|c|}
\hline \multicolumn{2}{|c|}{ QUESTÃO } & ENUNCIADO & PARECER \\
\hline \multirow[t]{2}{*}{1.0} & A. 3 & $\begin{array}{l}\text { "Uma atitude geral da vontade do } \\
\text { homem favorável a Deus ou favorável á } \\
\text { ética e à moral". }\end{array}$ & $\begin{array}{l}\text { Dúvidas poderiam surgir na tabulação } \\
\text { das respostas pelo emprego da } \\
\text { preposição "ou" no enunciado da } \\
\text { questão. }\end{array}$ \\
\hline & 1.1 & $\begin{array}{l}\text { "Se a religião tem vários elementos, } \\
\text { qual é para vocé o mais importante?" }\end{array}$ & $\begin{array}{lcc}\text { Conotações } & \text { ofensivas e } & \text { ou } \\
\text { "policialescas" } & \text { poderiam } & \text { ser } \\
\text { abstraidas do termo elementos. } & \end{array}$ \\
\hline \multirow[t]{2}{*}{2.0} & 2.1 & $\begin{array}{l}\text { "Como você compreende a relação de } \\
\text { Deus com a humanidade e com você } \\
\text { pessoalmente". }\end{array}$ & $\begin{array}{l}\text { Duas questões estão sendo } \\
\text { formuladas em um único enunciado. }\end{array}$ \\
\hline & 2.2 & $\begin{array}{l}\text { "Se sua posição sobre as duas relaçōes } \\
\text { for incerta, por favor, declare este fato". }\end{array}$ & $\begin{array}{l}\text { O uso do adjetivo "incerto" denota um } \\
\text { pré-julgamento no enunciado da } \\
\text { questão. }\end{array}$ \\
\hline 4.0 & & $\begin{array}{l}\text { "Ou você não acredita em Deus tanto } \\
\text { quanto quer fazer uso Dele". }\end{array}$ & $\begin{array}{l}\text { Questão ofensiva. Começa com uma } \\
\text { negativa e, em seguida, passa para } \\
\text { uma afirmativa, sugerindo que a } \\
\text { pessoa não acredita em Deus, mas } \\
\text { faz uso dele. }\end{array}$ \\
\hline 4.0 & 4.1 & $\begin{array}{l}\text { "Vocé aceita Deus não tanto como um } \\
\text { Ser real existente, mas de preferência, } \\
\text { como um ideal pelo qual se vive?". }\end{array}$ & $\begin{array}{l}\text { Enunciado de difícil compreensão, foi } \\
\text { sugerido que a questão fosse dividida } \\
\text { em duas. }\end{array}$ \\
\hline
\end{tabular}

(continua) 
QUADRO 1 - Avaliação dos juizes sobre o conteúdo das questões do "Inventário de crenças religiosas no esporte": primeira fase. (continuação)

\begin{tabular}{|c|c|c|c|}
\hline 4.0 & 4.2 & $\begin{array}{l}\text { "Se você tivesse que se tomar } \\
\text { inteiramente convencido de que Deus } \\
\text { não existe, isso faria uma grande } \\
\text { diferença em sua vida - seja com } \\
\text { relação à felicidade, moralidade ou a } \\
\text { outros aspectos?" }\end{array}$ & $\begin{array}{l}\text { o espaço destinado à resposta foi } \\
\text { considerado insuficiente. Foi sugerido } \\
\text { que a questão fosse subdividida em } \\
\text { cada uma de suas especificidades : } \\
\text { felicidade, moralidade e outros } \\
\text { aspectos. }\end{array}$ \\
\hline 6.0 & & $\begin{array}{l}\text { "Vocé reza? E, se for o caso por quê? } \\
\text { Quer dizer é puramente por habito e } \\
\text { costume social, ou você acredita que } \\
\text { Deus ouve suas preces?". }\end{array}$ & $\begin{array}{l}\text { Foi sugerido que a questão seja } \\
\text { subdividida em cada um de seus três } \\
\text { componentes. }\end{array}$ \\
\hline 8.0 & & "Vocé acredita na imortalidade pessoal" & $\begin{array}{l}\text { foi sugerida uma altemativa para o } \\
\text { enunciado: "Pessoalmente, você } \\
\text { acredita no conceito de imortalidade". }\end{array}$ \\
\hline 9.0 & & $\begin{array}{l}\text { "Você aceita a Biblia como autoridade } \\
\text { em questōes religiosas ?" }\end{array}$ & $\begin{array}{l}\text { O sentido do termo autoridade foi } \\
\text { questionado. Foi sugerido como } \\
\text { alternativa: "Você aceita a Biblia } \\
\text { como única referência em questões } \\
\text { religiosas?" }\end{array}$ \\
\hline & 9.1 & $\begin{array}{l}\text { "Sua fé religiosa e a sua vida são } \\
\text { baseadas nela? Se for o caso, de que } \\
\text { modo a sua crença em Deus e a sua } \\
\text { vida favorável a Ele e aos } \\
\text { companheiros humanos seriam } \\
\text { afetadas pela perda da autoridade da } \\
\text { Biblia?" }\end{array}$ & $\begin{array}{l}\text { São feitas várias perguntas em um } \\
\text { único enunciado, o juiz sugere que a } \\
\text { questão seja feita perguntando uma } \\
\text { questão de cada vez. }\end{array}$ \\
\hline
\end{tabular}

Dando continuidade ao processo de adaptação do instrumento ao meio esportivo, considerando-se as críticas, recomendações e sugestões dos juizes, 0 instrumento foi reformulado.

\subsubsection{Segunda fase de desenvolvimento do Inventário de crenças religiosas no esporte: validação por especialistas}

Os itens considerados confusos, agressivos e ou ofensivos pelos juizes na primeira fase de validação do instrumento foram eliminados. Pelo aprofundamento da revisão de literatura em torno das obras de PRATT $(1907,1923)$, foram inseridos no instrumento sobre aspectos relativos à crença ético-moral.

Implementadas estas modificaçöes, o instrumento agora denominado Inventário de crenças religiosas no esporte (APENDICE VII) foi novamente submetido à avaliação de especialistas, entre os quais a professora Marta Helena de 
Freitas, psicóloga que defendeu tese de doutorado sobre crenças religiosas em um estudo feito por meio do questionário Pratt de crenças religiosas e do método de Rorschach. O professor Mestre Luiz Fernando Bacchereti, psicólogo com incursões na área do esporte, recursos humanos e técnicas de exames psicológicos, e Luiza Klein Alonso, socióloga Pós-Doutora pela University of Califórnia, Doutora em Educação pela Harvard University, professora e pesquisadora que tem feito inúmeras contribuições à psicologia e aos estudos que se desenvolvem na área do esporte na Escola de Educação Física e Esporte da Universidade de São Paulo, e nos trabalhos desenvolvidos pelo grupo de estudos e pesquisas em psicossociologia do esporte (GEPPSE) coordenado pelo professor Doutor Antonio Carlos Simōes.

Houve $100 \%$ de concordância entre os juizes quanto à adequação do título, fluência verbal, seqüência das questões e adequação dos espaços destinados às respostas. Os formulários de avaliação do instrumento encontram-se nos APÊNDICES XI, X e XI. A Professora Luiza Klein Alonso considerou satisfatórias e bem articuladas as modificações; O professor Luiz Fernando Bacchereti concordou; e a Professora Marta Helena Freitas julgou o material interessante e pertinente, com fluência verbal, seqüência adequada e que os espaços destinados às respostas foram uma decisão acertada, sugestão que declarou ter recebido, tanto dos juízes como dos sujeitos de sua pesquisa. Acrescentando que considerou positiva a inclusão da modalidade crença ético-moral no instrumento, uma dimensão de crença religiosa que ela própria não explorou mais profundamente em virtude das dificuldades em se resgatar as obras de PRATT (1923).

Quanto ao conteúdo especifico das questões, houve $92,86 \%$ de concordância entre os juizes, isto significa que o instrumento enviado para avaliação constava de 14 itens organizados em torno de dez questōes, portanto, em um universo de 42 possibilidades os juizes sugeriram três modificaçōes - questōes dois, seis e dez. Nesse processo, foram feitas novas sugestões ao acréscimo de três itens, conforme demonstrado no QUADRO 2. 
QUADRO 2 - Avaliação dos juizes sobre o conteúdo das questōes do "Inventário Pratt de crenças religiosas no esporten: segunda fase.

\begin{tabular}{|c|l|l|}
\hline Q. & \multicolumn{1}{|c|}{ ENUNCIADO } & \multicolumn{1}{|c|}{ PARECER } \\
\hline $\mathbf{2 . 0}$ & $\begin{array}{l}\text { "Por que você acredita em Deus? } \\
\text { É... }\end{array}$ & $\begin{array}{l}\text { Foi questionada a possibilidade da } \\
\text { pessoa não acreditar em Deus. }\end{array}$ \\
\hline $\mathbf{5 . 0}$ & $\begin{array}{l}\text { "Você acredita que Deus poderia } \\
\text { ajudar a vencer obstáculos no } \\
\text { esporte?" }\end{array}$ & $\begin{array}{l}\text { Foi sugerida a inclusão de um item } \\
\text { relativo a perdas - recorrer a Deus para } \\
\text { lidar com a derrota. }\end{array}$ \\
\hline $\mathbf{6 . 0}$ & $\begin{array}{l}\text { "Deus seria um suporte emocional } \\
\text { para o atleta?" }\end{array}$ & $\begin{array}{l}\text { Foi sugerido substituir o termo } \\
\text { emocional por psicológico. }\end{array}$ \\
\hline $\mathbf{7 . 0}$ & $\begin{array}{l}\text { "Você reza para obter a vitória nas } \\
\text { competições esportivas?" }\end{array}$ & $\begin{array}{l}\text { Foi sugerida a inclusão de um item } \\
\text { relativo a perdas - recorrer à oração } \\
\text { para lidar com a derrota. }\end{array}$ \\
\hline $\mathbf{1 0}$ & $\begin{array}{l}\text { "Você se considera uma pessoa } \\
\text { supersticiosa" }\end{array}$ & $\begin{array}{l}\text { Foi considerado que a questão poderia } \\
\text { soar de forma agressiva, confusa sendo } \\
\text { desnecessária. }\end{array}$ \\
\hline & $\begin{array}{l}\text { Foi sugerido que se acrescentasse uma } \\
\text { segunda questão para avaliar o } \\
\text { significado de Deus para o atleta. }\end{array}$ \\
\hline
\end{tabular}

Apesar do alto índice de concordância $(92,86 \%)$, as alterações e sugestōes formuladas pelos juizes foram consideradas importantes e acatadas. $O$ enunciado da questão "Por que você acredita em Deus? É ..." foi alterado para "Você acredita em Deus ? É ..." (mantendo-se intactas as alternativas de resposta). Alteração que tornou o instrumento mais versátil, de forma que pode ser respondido tanto por pessoas que acreditam em Deus, como por aquelas pessoas que declaram não acreditar em Deus.

A questão relativa à superstição foi eliminada e, nesse processo, acrescentou-se uma questão que pudesse investigar melhor o significado de Deus ao desportista, conforme parecer da professora Marta Helena Freitas, que considera a forma como a pessoa define Deus importante para que se possa avaliar a modalidade de crença religiosa, na qual esta definição sustenta-se. Acatando ainda a sugestão da pesquisadora relativa a implementação de itens para investigar as derrotas, objetivando apreender melhor o significado em torno dos valores envolvidos na atitude religiosa dos atletas em relação a Deus, sejam de cunho mais 
existencial, orar para encontrar sentido na derrota ou de cunho mais utilitarista rezar para obter a vitória nas competiçōes esportivas (APÊNDICE IV)

Finalizando as concepções em torno da construção do "Questionário Pratt de Crenças Religiosas no Esporte", visando ampliar o campo de investigação sobre as bases em que se fundamentam as crenças religiosas dos atletas, sob as perspectivas em torno do questionário Pratt sobre Crenças religiosas, foi acrescentado um item relativo ao significado da espiritualidade ao atleta - Para você, o que significa "espiritualidade"? Finalizando, com o objetivo de amenizar um possivel caráter dicotômico que as questões dissertativas poderiam assumir diante das opções sim e não oferecidas logo após as questões, o pesquisador introduziu uma posição intermediária entre os pólos sim e não, mantendo a solicitação para que 0 respondente justificasse suas respostas.

As modificações resultaram no Inventário Pratt sobre crenças religiosas no esporte, que surge como sintese dos conhecimentos oriundos do campo da pesquisa fenomenológica sobre crenças religiosas nos últimos 100 anos, que se definem em torno das crenças religiosas: primitiva, intelectual, emocional e éticomoral.

Desta forma o inventário Pratt de crenças religiosas no esporte fornece aos atletas parâmetros para posicionarem diante daquelas questões que geram dúvidas e confusões e abre espaço para manifestação de outros posicionamentos.

\subsection{A Escala multidimensional do lócus de controle do esporte (EMLCE)}

O instrumento denominado escala mutidimensional de lócus de controle do esporte foi desenvolvido e adaptado pelo pesquisador ao meio esportivo com o objetivo de obter dados a respeito das expectativas dos esportistas com relação ao lócus controle de suas ações, seja quanto ao lócus interno - atletas que percebem os acontecimentos em suas vidas, como resultantes de suas próprias atitudes. 0 lócus de controle externo sorte-azar - atletas que percebem ou creditam os acontecimentos em suas vidas como resultantes da ação do acaso, sorte, azar e ou destino. E o lócus de controle externo pessoas poderosas - atletas que percebem os acontecimentos em suas vidas como fruto da açäo ou influéncia de pessoas 
poderosas instituiçōes figuras de autoridade e ou poder.

A metodologia empregada na construção deste instrumento procura seguir os procedimentos metodológicos adotados por LEVENSON (1973) na construção da Multidimensional locus of control in psychiatric patients, traduzida no Brasil por DELA COLETA (1987), sem mencionar a expressão pacientes psiquiátricos, denominou-o "Escala multidimensional de locus de controle de Levenson", instrumento que se embasa nos conceitos teóricos que apoiaram a construção da escala de lócus de controle de J. B. Rotter traduzida no Brasil por DELA COLETA (1979).

No início à busca por procedimentos metodológicos e instrumentos que pudessem auxiliar na compreensão do comportamento "místico e supersticioso" dos atletas (denominação inicial do projeto). Feita a constatação da inexistência de estudos realizados sobre as crenças dos atletas no Brasil. O pesquisador recorreu a estudos feitos no exterior, estabelecendo contato pessoal com o professor Dr. R. J. McKENNA; Ph.D., pela University of Connecticut, especialista em psicologia social, ligado ao departamento de psicologia na Hendrix College, Arkansas, (APÊNDICE V). R. J. McKENNA, foi o mentor de uma pesquisa realizada por JONES (2001) sobre o comportamento supersticioso no jogo de golfe e o lócus de controle utilizando a escala multidimensional do lócus de controle de J. B. Rotter, apresentada no 13th Annual Arkansas Symposium for psychology student, estudo que foi enviado ao pesquisador por R. J. McKENNA.

$\mathrm{Na}$ pesquisa, com abordagem comportamental, JONES (2001) considerou supersticioso o comportamento dos sujeitos que após uma tacada de golfe, bem sucedida, em uma nova jogada, buscavam manter a mesma cor da bola, usada na tacada anterior, mediante uma série de bolas de golfe de diversas cores disponibilizadas em um saco, ou ainda, os jogadores que rejeitavam sistematicamente a cor de uma bola, depois de tacadas mal sucedidas. O estudo foi pouco conclusivo devido a uma série de problemas operacionais, denotando uma estrutura relativamente simplista para abordar a complexidade que o fenômeno assume na esfera desta dissertação. No entanto, os conceitos definidos em torno da escala multidimensional do lócus de controle de J. B. Rotter e uma cópia do instrumento original de J. B. Rotter chamaram a atenção do pesquisador (APENDICEVI). 
$\mathrm{Na}$ seqüência aos estudos sobre lócus de controle, o pesquisador chegou à Multidimensional locus of control in psychiatric patients LEVENSON (1973) desenvolvida na University of Missouri para aplicações no âmbito da clinica psiquiátrica, instrumento que tem por base os conceitos de lócus de controle de J. B. Rotter, porém admitindo a multidimensionalidade do lócus de controle, pela subdivisão do lócus de controle externo em sorte-azar e ou pessoas poderosas. LEVENSON (1973) modificou o instrumento introduzindo o sistema de respostas em escala do tipo likert com seis posições, racionalizando o instrumento e tornado-o mais eficaz pela redução do número de questões e a análise mais detalhada ao lócus de controle externo.

Diante da inexistência de escalas de lócus de controle com validade no esporte no Brasil, o pesquisador decidiu pela criação de uma escala multidimensional do lócus de controle ao esporte, tomando por base os conceitos definidos por J. B. Rotter, com enfoque de natureza psicossocial, abstraído da teoria da aprendizagem e a metodologia empregada por LEVENSON (1973).

\subsubsection{Primeira fase de construção da escala multidimensional do lócus de controle do esporte}

A escala multidimensional do lócus de controle de J. B. Rotter sofreu algumas modificações (APÊNDICE XIV) com o objetivo de atualizar a linguagem e sugestōes feitas por J. A. DELA COLETA (1979) na tradução do instrumento para o português. Em seguida, foi enviada para análise dos juízes desta pesquisa: a professora Luiza Klein Afonso, a professora Sonia Maria da Silva e o Professor Luiz Fernando Baccherete, solicitando que avaliassem a orientação de cada um dos quarenta e oito itens da escala quanto a internalidade e a externalidade.

Houve $100 \%$ de concordância entre os três juizes (APENDICES XVI, XVII e $X V I I I)$, quanto a internalidade ou externalidade dos quarenta e oito itens sobre lócus de controle da escala de J. B. Rotter, exceto no filler item - três questões que foram inseridas por J. B. Rotter no instrumento original para "distrair" o respondente ou seja itens sem relação com o lócus de controle, dos quais, apenas um foi enviado aos juizes, tendo sido identificado. 


\subsubsection{Segunda fase de construção da escala multidimensional do lócus de controle do esporte}

Dando continuidade ao processo de desenvolvimento da escala multidimensional do lócus de controle do esporte, o pesquisador eliminou uma das questōes sobre lócus de controle da escala de J. B. Rotter, buscando adaptar o conteúdo da outra questão ao ambiente do esporte.

Paralelamente a este processo, o sistema de respostas foi implementado, pautado na metodologia empregada por LEVENSON (1973), respostas em escala do tipo likert de seis pontos, sistema que conserva a essência do conceito de lócus de controle de J. B. Rotter, ou seja, propiciar ao respondente uma situação hipotética, que possibilite conhecer a orientação do lócus de controle. Por isto, a utilização da escala likert com número impares de posiçōes, caracterizadas por uma posição central, neutra, seguida de enunciados do tipo não concordo nem discordo, indeterminado ou indeciso, foi descartada.

Desta forma, o sistema de respostas da "Escala multidimensional do lócus de controle do esporte" se diferencia da metodologia adotada nas escalas multidimensionais de lócus de controle no Brasil introduzido por DELA COLETA (1987) quando traduziu ao português a Multidimensional locus of control in psychiatric patients de Hanna Levenson, e modificou o sistema de respostas de escala, apoiada em pesquisas que comprovariam que a população brasileira tem dificuldades em responder escalas do tipo likert com mais de cinco posições.

Desta forma, com o objetivo de contornar as possiveis dificuldades de compreensão do instrumento no meio esportivo brasileiro, e manter-se fiel à gênese do conceito de lócus de controle de J. B. Rotter. O pesquisador associou a escala likert de seis pontos, o sistema pictográfico de respostas, utilizando-se de simbolos representativos de expressões faciais como agentes facilitadores das respostas, desenvolvidos com base na escala multidimensional do lócus de controle de OERTEL (2003) IPC - Fragebogen zu Kontrollüberzeugungen - escala multidimensional do lócus de controle adaptada na Alemanha pelo departamento de ciências do esporte da Humboldt Universität zu Berlin - Institut Für Sportwissenschaften 
O pesquisador associou as cores: vermelho (discordo) e verde (concordo) variando em grau de intensidade segundo uma escala do tipo dégradé $(H$ 195-5 CVC, H 195-3 CVC, H 195-1 CVC, H 570-7 CVC, H 570-5 CVC, H 570-3 CVC), desenvolvida no sistema Pantone hexacrome com cobertura disponibilizado no programa Corel Draw 9.0 Kodak Digital Science 1995 - 1997.

Portanto, a escala mutidimensional de lócus de controle do esporte constituise por três subescalas independentes, ou seja, escores elevados de lócus de controle interno, não implicam necessariamente em menores escores de lócus de controle externo sorte-azar e ou lócus de controle externo pessoas poderosas.

Cada uma das subescalas do instrumento são compostas por oito itens, cujos niveis de respostas variam em escala do tipo likert de seis pontos pictográfica vermelha e verde em dégradé, associadas aos seguintes enunciados: vermelho discordo totalmente (H 195-5 CVC), discordo (H 195-3 CVC) e verde: discordo parcialmente (H 195-1 CVC), concordo parcialmente (H 570-7 CVC), concordo (H 570-5 CVC) e concordo totalmente (H 570-3 CVC).

A correção das respostas utiliza a mesma metodologia adotada por LEVENSON (1973) atribuindo respectivamente os seguintes valores a cada um dos pontos da escala: $-3,-2,-1,+1,+2$ e +3 , adicionando-se a constante 24 a soma dos escores obtidos em cada uma das subescalas. Portanto os escores de lócus de controle variam entre 0 e 48 em cada uma das dimensōes do lócus de controle da escala multidimensional do lócus de controle do esporte. Desta forma, quanto maiores os escores obtidos pelos atletas na subescala multidimensional do lócus de controle interno (questões $1,2,5,9,18,19,21$ e 23) maior será a indicação de que ele atribui a si, a responsabilidade pelos acontecimentos em sua carreira. Quanto maiores os escores obtidos na subescala multidimensional do lócus de controle Externo pelo Acaso (LCE-A) questões 2, 6, 7, 10, 12, 14, 16 e 24 maior será a indicação que o atleta atribui à sorte, acaso, destino ou a Deus a responsabilidade pelos acontecimentos em sua carreira. E Quanto maiores os escores obtidos na subescala multidimensional do lócus de controle Externo Pessoas Poderosas (LCEPP) questões $3,8,11,13,16,17,20$ e 22 maior será a indicação que ele atribui à figuras de poder a responsabilidade pelos acontecimentos na carreira esportiva. 


\subsubsection{Terceira fase da construção da escala multidimensional do lócus de controle do esporte: validação do conteúdo e do sistema de respostas}

Em conformidade com os procedimentos adotados na validação dos instrumentos por juizes especialistas, a escala multidimensional do lócus de controle do esporte (APÊNDICE XIX), foi analisada por três juizes: Marilia Ferreira Dela Coleta, Luiz Fernando Baccherete e Luiza Klein Alonso, aos quais foi solicitado que emitissem pareceres sobre a adequação da linguagem e a validade das questōes para medir o lócus de controle para orientação ao lócus de controle interno, lócus de controle externo sorte-azar e o lócus de controle externo pessoas poderosas.

Houve $100 \%$ de concordância entre os juizes (APÊNDICES XXI, XXII e XXIII) sobre à estética e validade da escala likert de seis pontos pictográfica vermelha e verde em dégradé, considerada como uma excelente idéia que deixou o instrumento mais claro e eficiente.

Quanto ao conteúdo e orientação para lócus de controle interno das oito questões submetidas à avaliação dos três juízes, houve $79 \%$ de concordância entre os 24 pareceres. No entanto, os itens em que houve qualquer discordância dos juizes, foram revistas seguindo-se as próprias sugestões formuladas pelos juizes, tomando-se o cuidado de manter o equilibrio entre itens formulados de forma pessoal e itens formulados de forma impessoal. ROTTER; CHANCE \& PHARES (1972) afirma que itens formulados em primeira pessoa mobilizam mais o controle do ego, já os itens formulados de forma impessoal mobilizam menos o controle do ego, possibilitando desta forma, uma maior projeção do respondente nas questões formuladas de forma impessoal, quando pareados com itens formulados de forma pessoal.

As sugestōes e alterações antes e após de compostas pela análise dos juízes são destacadas no QUADRO 3. 
QUADRO 3 - Itens sobre lócus de controle interno da escala mutidimensional de lócus de controle do esporte antes e depois de implementadas as sugestões dos juizes

\begin{tabular}{|c|c|c|}
\hline \multirow[t]{2}{*}{01} & $\mathrm{P}$ & A instabilidade na carreira esportiva, resultaria das dificuldades dos próprios atletas. \\
\hline & $F$ & Para mim, a instabilidade na carreira esportiva resulta de dificuldades do próprio atleta. \\
\hline \multirow[t]{2}{*}{04} & $P$ & $\begin{array}{l}\text { Os resultados obtidos no esporte de rendimento, são proporcionais aos graus de } \\
\text { dedicação dos atletas. }\end{array}$ \\
\hline & $\mathrm{F}$ & Se eu me dedicar bastante, posso ter sucesso no esporte. \\
\hline 05 & $P F$ & $\begin{array}{l}\text { O sucesso no esporte é questão de muito trabalho e persistência. A sorte tem pouco ou } \\
\text { nada a ver com isto. }\end{array}$ \\
\hline \multirow[t]{2}{*}{09} & $P$ & $\begin{array}{l}\text { Um atleta profissional pode exercer uma certa influência, nas decisões do ministério do } \\
\text { esporte. }\end{array}$ \\
\hline & $F$ & $\begin{array}{l}\text { Se eu tiver sucesso na carreira esportiva, será principalmente por causa da minha } \\
\text { capacidade. }\end{array}$ \\
\hline 18 & $\mathrm{PF}$ & É raro encontrar um resultado de jogo injusto, o que existe, são atletas mal preparados. \\
\hline \multirow[t]{2}{*}{19} & $\mathrm{P}$ & A idéia de que os técnicos são injustos com os atletas, é uma bobagem. \\
\hline & $\mathrm{F}$ & Um fator importante no esporte, assim como na vida, é tomar as decisões certas. \\
\hline \multirow[t]{2}{*}{21} & $P$ & $\begin{array}{l}\text { É impossivel acreditar que o acaso ou a sorte possam ter um papel importante na carreira } \\
\text { de um atleta. }\end{array}$ \\
\hline & $F$ & $\begin{array}{l}\text { O atleta que segue corretamente uma carreira bem planejada, pode ficar tranqüilo quanto } \\
\text { ao seu futuro. }\end{array}$ \\
\hline \multirow[t]{2}{*}{23} & $P$ & $\begin{array}{l}\text { Um atleta pode decidir como vai ser o seu futuro, de acordo com aquilo que ele mesmo } \\
\text { faz no presente. }\end{array}$ \\
\hline & $F$ & $\begin{array}{l}\text { Posso decidir como vai ser o meu futuro, de acordo com aquilo que eu mesmo faço no } \\
\text { presente. }\end{array}$ \\
\hline
\end{tabular}

LEGENDA: P (Proposto) - F (Final)

O QUADRO 3 destaca os itens sobre lócus de controle interno apresentados aos juizes para avaliação e o formato final que adquiriram depois de implementadas as sugestōes e ajustes necessários.

Quanto ao conteúdo e orientação da subescala multidimensional do lócus de controle externo sorte-azar, houve $92 \%$ de concordância entre os juizes entre os 24 pareceres emitidos sobre as oito questões.

As sugestões e alterações feitas na subescala multidimensional do lócus de controle externo sorte-azar sob a orientação dos juizes da pesquisa são destacadas no QUADRO 4. 
QUADRO 4 - Itens sobre lócus de controle externo sorte-azar da escala mutidimensional de lócus de controle do esporte antes e depois de implementadas as sugestōes dos juizes

\begin{tabular}{|c|c|c|}
\hline \multirow[t]{2}{*}{02} & $\mathrm{P}$ & $\begin{array}{l}\text { Freqüentemente, quando se tem um pressentimento de que algo vai acontecer, de fato } \\
\text { acontece. }\end{array}$ \\
\hline & $\mathrm{F}$ & $\begin{array}{l}\text { Freqüentemente, quando eu tenho um pressentimento de que algo vai acontecer, de fato } \\
\text { acontece. }\end{array}$ \\
\hline \multirow[t]{2}{*}{06} & $P$ & $\begin{array}{l}\text { Não se deve fazer planos com muita antecedência, porque muitas coisas, acabam sendo } \\
\text { uma questão de sorte ou azar. }\end{array}$ \\
\hline & $\mathrm{F}$ & Aqueles que têm sucesso no esporte, realmente tiveram muita sorte. \\
\hline 07 & $\mathrm{PF}$ & São momentos oportunos, que fazem de um atleta qualquer, um super atleta. \\
\hline 10 & PF & $\begin{array}{l}\text { Para ser um atleta de sucesso, depende de estar no esporte certo, na equipe certa e na } \\
\text { hora certa. }\end{array}$ \\
\hline \multirow[t]{2}{*}{12} & $P$ & $\begin{array}{l}\text { Às vezes, um atleta pode decidir melhor o que fazer, simplesmente tirando a sorte com } \\
\text { uma moeda. }\end{array}$ \\
\hline & $\mathrm{F}$ & Muitas coisas que afetam a carreira de um atleta acontecem por acaso. \\
\hline \multirow[t]{2}{*}{14} & $P$ & $\begin{array}{l}\text { Se um atleta, vai sofrer ou não, um acidente durante o desenvolvimento de um jogo, isso } \\
\text { é uma questão de sorte. }\end{array}$ \\
\hline & $\mathrm{F}$ & $\begin{array}{l}\text { Se eu vou ou não, sofrer um acidente durante o desenvolvimento de um jogo, isso é uma } \\
\text { questão de sorte. }\end{array}$ \\
\hline 16 & PF & $\begin{array}{l}\text { Durante um jogo qualquer, na hora "H", é Deus quem mostra para o atleta a direção } \\
\text { certa. }\end{array}$ \\
\hline \multirow[t]{2}{*}{24} & $\mathrm{P}$ & No fim das contas, as coisas ruins acabam sendo compensadas pelas coisas boas. \\
\hline & $\mathrm{F}$ & Se for meu destino, eu me darei bem no esporte \\
\hline
\end{tabular}

LEGENDA: P (Proposto) - F (Final)

O QUADRO 4 destaca a versão final dos itens sobre lócus de controle externo sorte-azar, apresentados aos juizes para avaliação, assim como o formato final que adquiriram depois de implementadas as sugestões e ajustes necessários. $\mathrm{Na}$ questão 6, embora tenha havido concordância, decidiu-se por incluir um dos itens sugeridos pela professora Marilia Ferreira Dela Coleta por considerar que expressa a idéia de forma mais objetivamente.

Quanto ao conteúdo e orientação da subescala multidimensional do lócus de controle externo pessoas poderosas, houve $75 \%$ de concordância os entre os 24 pareceres emitidos. As sugestões e alteraçōes feitas nos itens da subescala multidimensional do lócus de controle externo pessoas poderosas são destacadas no QUADRO 5. 
QUADRO 5 - Itens sobre lócus de controle externo pessoas poderosas da escala mutidimensional de lócus de controle do esporte antes e depois de implementadas as sugestões dos juizes

\begin{tabular}{|c|c|c|}
\hline 03 & PF & $\begin{array}{l}\text { Se as pessoas gostam de um atleta, é porque simplesmente gostam. Dai, não adiante se } \\
\text { esforçar muito para ser agradável. }\end{array}$ \\
\hline \multirow[t]{2}{*}{08} & $P$ & $\begin{array}{l}\text { Sempre haverá violência entre as grandes torcidas, não importa o que se faça para tentar } \\
\text { evità-la. }\end{array}$ \\
\hline & $F$ & $\begin{array}{l}\text { Para alcançar uma posição privilegiada no esporte, vou precisar da ajuda de pessoas } \\
\text { influentes. }\end{array}$ \\
\hline \multirow[t]{2}{*}{11} & $\mathrm{P}$ & $\begin{array}{l}\text { Infelizmente o valor de um atleta passa muitas vezes sem ser reconhecido, não importa o } \\
\text { quanto ele se esforce. }\end{array}$ \\
\hline & $\mathrm{F}$ & $\begin{array}{l}\text { Se eu tiver sucesso no esporte, será por causa das pessoas que cuidaram da minha } \\
\text { careira. }\end{array}$ \\
\hline \multirow[t]{2}{*}{13} & $\mathrm{~F}$ & $\begin{array}{l}\text { No mundo dos esportes, na maioria das vezes, os atletas são vitimas de forças e } \\
\text { pressōes que não conseguem controlar. }\end{array}$ \\
\hline & $\mathrm{F}$ & O atleta, na maioria das vezes, tem que agir segundo o interesse de outras pessoas. \\
\hline \multirow[t]{2}{*}{15} & $\mathrm{P}$ & $\begin{array}{l}\text { O esporte é controlado pelos poucos que estão no poder, e não há nada que um simples } \\
\text { atleta possa fazer a respeito disso }\end{array}$ \\
\hline & $\mathrm{F}$ & Minha carreira no esporte depende muito de outras pessoas. \\
\hline 17 & $\mathrm{~F}$ & $\begin{array}{l}\text { Na maioria das vezes, não dá para entender porque os políticos agem desta ou daquela } \\
\text { forma com relação ao esporte. }\end{array}$ \\
\hline \multirow[t]{2}{*}{20} & $\mathrm{P}$ & $\begin{array}{l}\text { No esporte, muitas vezes, é dificil saber quando uma pessoa gosta realmente ou não de } \\
\text { um atleta. }\end{array}$ \\
\hline & $\mathrm{F}$ & $\begin{array}{l}\text { Apesar de ter boa capacidade para o esporte, so conseguirei chegar onde quero se eu } \\
\text { tiver ajuda de pessoas importantes. }\end{array}$ \\
\hline 22 & PF & $\begin{array}{l}\text { Na maioria das vezes, são os detentores do poder esportivo, que decidem os rumos da } \\
\text { vida do atleta. }\end{array}$ \\
\hline
\end{tabular}

LEGENDA: P (Proposto) - F (Final)

O QUADRO 5 destaca a versão final dos itens sobre lócus de controle externo pessoas poderosas, antes De se implementar as sugestões e os ajustes que se fizeram necessários, completando, desta forma, a metodologia de construção e validação da estática, linguagem, conteúdo e adequação dos construtos definidos em torno do conceito de lócus de controle, realizada por juizes especialistas, a versão final do instrumento é apresentada no ANEXO III. 


\subsubsection{Confiabilidade da escala multidimensional do lócus de controle do} esporte: análise da consistência interna pelo alfa de Crombach

O exame da consistência interna é usado para estabelecer a precisão do instrumento. A escala mutidimensional do lócus de controle do esporte foi analisada estatisticamente pelo calculo do coeficiente de alfa de Crombach, empregando-se o programa computacional The SAS System for Windows (Statistical Analises Sytem), versão 6.12. SAS Institute Inc. 1989-1996, NC, USA. Resultou em uma consistência intermediária ao instrumento no total. A análise por domínios mostrou baixa consistência ao lócus de controle interno, consistência intermediária ao lócus de controle externo sorte-azar e consistência intermediária ao lócus de controle externo pessoas poderosas.

Valores de alfa de Crombach maiores de 0.80 indicam alta consistência interna, ao passo que valores acima de 0,60 mostram consistência intermediaria, os valores de alfa de Crombach obtidos ao instrumento em análise são destacados no dados da TABELA 1.

TABELA 1 - Análise da consistência interna da escala lócus de controle: valores de alfa de Crombach

\begin{tabular}{|c|c|c|c|c|c|c|}
\hline Domínios & $\mathrm{N}$ & $\begin{array}{r}\text { Alfa de } \\
\text { Crombach }\end{array}$ & $\begin{array}{r}\text { Itens com men } \\
\text { consistên }\end{array}$ & $\begin{array}{l}\text { nor } \\
\text { cia }\end{array}$ & $\begin{array}{r}\text { Correlação } \\
\text { com o Total* }\end{array}$ & $\begin{array}{r}\text { Valor do alfa } \\
\text { (depois de } \\
\text { retirada dos } \\
\text { itens) }\end{array}$ \\
\hline & \multirow{4}{*}{24} & \multirow{4}{*}{0,683} & LC & 19 & 0,066 & 0,689 \\
\hline LC & & & LC & 23 & 0,083 & 0,694 \\
\hline \multirow[t]{2}{*}{ Itens 1 a 24} & & & LC & 5 & 0,108 & 0,697 \\
\hline & & & LC & 4 & 0,100 & 0,701 \\
\hline LCI & \multirow{2}{*}{8} & \multirow{2}{*}{0,425} & LC & 19 & $-0,048$ & 0,490 \\
\hline Itens $1,4,5,9,18,19,21,23$ & & & LC & 23 & 0.037 & 0,535 \\
\hline LCE A - SA & \multirow{2}{*}{8} & \multirow{2}{*}{0,587} & LC & 10 & 0,176 & 0,589 \\
\hline Itens $2,6,7,10,12,14,16,24$ & & & LC & 7 & 0,157 & 0,602 \\
\hline LCE - PP & \multirow{2}{*}{8} & \multirow{2}{*}{0,581} & LC & 17 & 0,115 & 0,600 \\
\hline Itens $3,8,11,13,15,17,20,22$ & & & LC & 3 & 0119 & 0,627 \\
\hline
\end{tabular}


A TABELA 1 destaca a análise da consistência interna pelo alfa de Crombach da escala multidimensional do lócus de controle do esporte, alfa 0.683 ao instrumento em sua totalidade. Visto que a análise da consistência interna do dominio lócus de controle interno mostrou um valor alfa 0,535, após a retirada dos itens LC 19 Um fator importante no esporte, assim como na vida, é tomar as decisões corretas e LC 23 Posso decidir como vai ser o meu futuro, de acordo com aquilo que eu mesmo faço no presente.

O dominio lócus de controle externo sorte-azar mostrou um valor de alfa 0,587 passando a alfa 0,602 após a retirada dos itens LC 10 Para ser um atleta de sucesso, depende de estar no esporte certo, na equipe certa e na hora certa e LC 7 são momentos oportunos, que fazem de um atleta qualquer, um superatleta.

O domínio lócus de controle externo pessoas poderosas mostrou o valor alfa 0,581 passando a alfa 0,600 após a retirada do item LC 17 Na maioria das vezes, não dá para entender porque os políticos agem desta ou daquela forma com relação ao esporte, para alfa 0,627 após a retirada do item LC 3 Se as pessoas gostam de um atleta, é porque simplesmente gostam. Daí, não adianta se esforçar muito para ser agradável.

Para que se possa estabelecer um quadro comparativo sobre os valores da consistência interna da escala multidimensional do lócus de controle de esporte sobre os valore iniciais obtidos no handebol com os resultados obtidos em outros estudos, utilizando diferentes escalas e populaçōes. O QUADRO 6 destaca o cálculo do valor alfa de Crombach obtido na validação de diferentes instrumentos em estudos e pesquisas. 
QUADRO 6 - Comparativo do alfa de Crombach na validação de escalas multidimensionais de lócus de controle em diferentes estudos

\begin{tabular}{|c|c|c|c|c|c|c|}
\hline \multirow{2}{*}{ INSTRUMENTO } & \multirow{2}{*}{ PESQUISADOR } & \multirow{2}{*}{ POPULAÇÃO } & \multirow{2}{*}{$\mathbf{N}$} & \multicolumn{3}{|c|}{ Lócus } \\
\hline & & & & 11 & E-AS & E-PP \\
\hline $\begin{array}{r}\text { Multidimensional Locus of } \\
\text { Control in Psychiatric } \\
\text { Patients }\end{array}$ & $\begin{array}{r}\text { Levenson } \\
\text { (1971) }\end{array}$ & $\begin{array}{r}\text { Psicoticos } \\
\text { hospitalizados }\end{array}$ & 165 & 0,67 & 0,79 & 0,82 \\
\hline $\begin{array}{r}\text { Health Locus of Control } \\
\text { Scale }\end{array}$ & $\begin{array}{r}\text { Wallston \& } \\
\text { Wallston (1981) }\end{array}$ & Universitários & 112 & 0,61 & 0,56 & 0,70 \\
\hline $\begin{array}{r}\text { Escala multidimensional do } \\
\text { Locus de Controle de } \\
\text { Levenson }\end{array}$ & $\begin{array}{r}\text { DELA COLETA } \\
\text { (1987) }\end{array}$ & Universitários & 675 & 0,50 & 0,62 & 0,63 \\
\hline $\begin{array}{r}\text { Escala multidimensional do } \\
\text { Locus de Controle de } \\
\text { Levenson }\end{array}$ & $\begin{array}{r}\text { Tamayo } \\
\text { (1989) }\end{array}$ & Universitários & 1199 & 0,57 & 0,70 & 0,68 \\
\hline $\begin{array}{r}\text { Escala de locus de Controle } \\
\text { de Saúde }\end{array}$ & $\begin{array}{r}\text { DELA COLETA } \\
\text { (2004) }\end{array}$ & Universitários & 580 & 0,62 & 0,63 & 0,59 \\
\hline $\begin{array}{r}\text { Escala de Multidimensional } \\
\text { Locus de Controle do } \\
\text { Esporte* }\end{array}$ & $\begin{array}{r}\text { Conceição } \\
\text { (2004) }\end{array}$ & $\begin{array}{l}\text { Atletas de } \\
\text { handebol }\end{array}$ & 111 & 0,53 & 0,60 & 0,63 \\
\hline
\end{tabular}

" valores após a retirada dos itens que apresentaram menor correlaçâo em seus respectivos dominios.

Nos dados do QUADRO 6 destacam-se os parâmetros psicométricos estabelecidos para a validação de distintas escalas multidimensionais de lócus de controle em diferentes estudos e pesquisas pelo cálculo do alfa de Crombach, do século $X X$, assim possibilitando estabelecer uma análise comparativa entre esses valores e os de alfa de Crombach, obtidos pela escala multidimensional do lócus de controle do esporte, quando retirados os itens de menor correlação, constatou-se que os valores são similares aos resultados obtidos em outras pesquisas. Concluindo-se pela validação discriminativa da escala multidimensional do lócus de controle do esporte na análise comparativa com outros instrumentos.

No entanto, é preciso investigar se os valores de alfa de Crombach nos itens que mostraram menor correlação mantêm-se em outras aplicaçōes, para se decidir pela retirada ou não dos seis itens de menor correlação com os demais, que, desta 
forma, ficaria com 18 itens, igualando-se ao número de itens da Multidimentional health locus of control scale, cuja versão $A$ foi traduzida e adaptada no Brasil por DELA COLETA (2004) sob a denominação Escala multidimensional do lócus de controle da saúde.

\subsubsection{Validade fatorial da escala multidimensional do lócus de controle do esporte}

Para TAMAYO (1989) a natureza multidimensional do constructo lócus de controle, exige uma abordagem fatorial para que se possa determinar o valor da medida do instrumento por meio da análise estatística de sua estrutura. Desse modo, a escala multidimensional do lócus de controle do esporte foi analisada fatorialmente pelo método das componentes principais.

Para verificar como se agrupam os 24 itens da escala, foi feita a rotação ortogonal (varimax) com o objetivo de deixar os fatores resultantes 0 mais independente possivel, e a definição do número de fatores foi feita pelos mesmos critérios utilizados por TAMAYO (1989) autovalor (eigenvalue) ${ }^{10}$ maiores que 1.5 , os cálculos foram feitos utilizando-se o programa computacional The SAS System for Windows - Statistical Analises Sytem, versão 6.12 SAS Institute Inc., 1989 -1996, NC, USA e o SPSS versão 10.0, SPSS INC, 1989 - 1999, USA.

$A$ análise resultou em quatro fatores e uma carga fatorial que explica $35.2 \%$ da variabilidade total. No APENNDICE XI encontram-se as cargas fatoriais por item, após a rotação ortogonal da escala multidimensional do lócus de controle do esporte. Os dados da TABELA 2 destacam a composição dos quatro fatores resultantes por ordem de carga fatorial.

\footnotetext{
${ }^{10}$ Autovalor (eigenvalue) estatisticamente definido como a raiz latente, representa a variabilidade da amostra por fatores (HAIR, ANDERSON, TATHAN \& BLACK, 1998) ou seja o número de variáveis englobadas pelo fator, é comum na análise fatorial considerar apenas valores de eigenvalue maior que 1.0 e cargas fatoriais superiores a 0,40 .
} 
TABELA 2 - Análise fatorial: composição dos agrupamentos resultantes após rotação ortogonal (varimax)

\begin{tabular}{|c|c|c|c|c|}
\hline & CARGA & ITE & & ESCALA MULTIDIMENCIONAL DE LOCCUS DE CONTROLE DO ESPORTE \\
\hline \multirow{8}{*}{ I } & 0,634 & LC8 & PP & $\begin{array}{l}\text { Para alcancar uma posição privilegiada no esporte, vou precisar } \\
\text { da ajuda de pessoas influentes. }\end{array}$ \\
\hline & 0,605 & LC6 & SA & $\begin{array}{l}\text { Aqueles que tem sucesso no esporte, realmente tiveram muita } \\
\text { sorte. }\end{array}$ \\
\hline & 0,567 & LC11 & PP & $\begin{array}{l}\text { Se eu tiver sucesso no esporte, será por causa das pessoas que } \\
\text { cuidaram da minha carreira. }\end{array}$ \\
\hline & 541 & LC15 & PP & Minha carreira no esporte depende muito de outras pessoas. \\
\hline & 0,486 & LC20 & $P P$ & $\begin{array}{l}\text { Apesar de ter boa capacidade para o esporte, só conseguirei } \\
\text { chegar onde eu quero se tiver ajuda de pessoas importantes. }\end{array}$ \\
\hline & 0,423 & LC16 & SA & $\begin{array}{l}\text { Durante um jogo qualquer, na hora "H", é Deus quem mostra para } \\
\text { o atleta a direção certa. }\end{array}$ \\
\hline & 0,401 & LC12 & $\mathrm{SA}$ & $\begin{array}{l}\text { Muitas coisas que afetam a carreira de um atleta acontecem por } \\
\text { acaso. }\end{array}$ \\
\hline & 0,392 & LC10 & SA & $\begin{array}{l}\text { Para ser um atleta de sucesso, depende de estar no esporte } \\
\text { certo, na equipe certa e na hora certa. }\end{array}$ \\
\hline \multirow{6}{*}{ II } & 0,632 & LC 1 & I & $\begin{array}{l}\text { Para mim, a instabilidade na carreira esportiva resulta de } \\
\text { dificuldades do próprio atleta. }\end{array}$ \\
\hline & 0,588 & LC 3 & $\mathrm{PP}$ & $\begin{array}{l}\text { Se as pessoas gostam de un atleta, é porque simplesmente } \\
\text { gostam. Dai, não adiante se esforçar para ser agradável. }\end{array}$ \\
\hline & 0,575 & LC18 & I & $\begin{array}{l}\text { É raro encontrar um resultado de jogo injusto, o que existe, } \\
\text { são atletas mal preparados. }\end{array}$ \\
\hline & 0,497 & LC5 & $I$ & $\begin{array}{l}\text { sucesso no esporte é questão de muito trabalho } \\
\text { persistência. A sorte tem pouco ou nada a ver com isso. }\end{array}$ \\
\hline & 0,456 & LC7 & $\mathrm{SA}$ & $\begin{array}{l}\text { São momentos oportunos, que fazem de um atleta qualquer, um } \\
\text { super atleta. }\end{array}$ \\
\hline & 0,372 & LC17 & PP & $\begin{array}{l}\text { Na maioria das vezes, não dá para entender porque os politicos } \\
\text { agem desta ou daquela forma com relação ao esporte. }\end{array}$ \\
\hline \multirow{5}{*}{ III } & 0,664 & LC13 & PP & $\begin{array}{l}\text { O atleta, na maioria das vezes, tem que agir segundo os } \\
\text { interesses de outras pessoas. }\end{array}$ \\
\hline & 0,601 & LC22 & PP & $\begin{array}{l}\text { Na maioria das vezes, são os detentores do poder esportivo, que } \\
\text { decidem os rumos da vida do atleta. }\end{array}$ \\
\hline & 0,430 & LC2 & SA & $\begin{array}{l}\text { Freqüentemente, quando eu tenho um pressentimento de que algo } \\
\text { vai acontecer, de fato acontece. }\end{array}$ \\
\hline & 0,399 & LC19 & I & $\begin{array}{l}\text { Um fator importante no esporte, assim como na vida, é tomar as } \\
\text { decisóes certas. }\end{array}$ \\
\hline & 0,379 & LC14 & SA & $\begin{array}{l}\text { Se eu vou ou não, sofrer um acidente durante o desenvolvimento } \\
\text { de um jogo, isso é uma questão de sorte. }\end{array}$ \\
\hline \multirow{5}{*}{ IV } & 0,647 & LC9 & $I$ & $\begin{array}{l}\text { Se eu tiver sucesso na carreira esportiva, será principalmente } \\
\text { por causa da minha capacidade. }\end{array}$ \\
\hline & 0,573 & LC4 & $I$ & Se eu me dedicar bastante, posso ter sucesso no esporte. \\
\hline & 0,529 & LC24 & $I$ & Se for meu destino, eu me darei bem no esporte. \\
\hline & 0,397 & $2 C 21$ & I & $\begin{array}{l}\text { o atleta que segue corretamente uma carreira bem planejada, } \\
\text { pode ficar tranqüilo quanto ao seu futuro. }\end{array}$ \\
\hline & 0,217 & $\mathrm{LC} 23$ & I & $\begin{array}{l}\text { Posso decidir como vai ser o meu futuro, de acordo com aquilo } \\
\text { que eu mesmo faco no presente. }\end{array}$ \\
\hline
\end{tabular}


Pela estrutura dos fatores apresentados na TABELA 2, nota-se que o primeiro fator agrupou apenas itens relativos ao lócus de controle externo, e o lócus pessoas poderosas é que o que se apresenta mais bem definido. Os segundo e o terceiro fatores se se mostraram misturados. No quarto fator, o predomínio de itens relativos ao lócus de controle interno. No entanto, a análise fatorial é fraca. Diante desses resultados, buscou-se verificar a adequação da amostra a este tipo de estudo pela medida MSA / KMO (Kaiser Méier Olkin), assim, os resultados análise são apresentados na TABELA 3.

TABELA 3 - Adequação da amostra e autovalores (eigenvalue) da análise fatorial da escala multidimensional do lócus de controle do esporte

\begin{tabular}{|c|c|c|c|c|c|c|c|c|c|}
\hline \multirow{2}{*}{$\begin{array}{l}\text { MEDIDA DZ } \\
\text { KO Kaiser }\end{array}$} & \multirow{2}{*}{$\begin{array}{l}\text { A AI } \\
\text { Meier }\end{array}$} & \multirow{2}{*}{$\begin{array}{l}\text { ADEQUAÇÃO } \\
\text { I Olkin's }\end{array}$} & \multirow{2}{*}{$\begin{array}{c}\mathrm{DA} \\
\text { Measure }\end{array}$} & \multicolumn{2}{|c|}{ AMOSTRA } & \multirow{2}{*}{$\begin{array}{l}\text { PARA A } \\
\text { Adequacy: }\end{array}$} & \multirow{2}{*}{$\begin{array}{l}\text { ANÁLISE } \\
\text { Over-aIl }\end{array}$} & \multicolumn{2}{|c|}{ FATORIAI } \\
\hline & & & & of & Sampling & & & $\underline{M S A}$ & 0,5388 \\
\hline & & 1 & 2 & & 3 & 4 & 5 & & 6 \\
\hline AUTOVALOR & & 3,1995 & 2,0252 & & 1,6620 & $\underline{1,5485}$ & 1,4525 & & 1,3941 \\
\hline \& EXPIICADA & & $\underline{0,1333}$ & $\underline{0,0844}$ & & 0,0692 & 0,0645 & 0,0605 & & 0,0581 \\
\hline \& ACUMULADA & & 0,1333 & 0,2177 & & 0,2869 & $\underline{0,3515}$ & 0,4120 & & 0,4701 \\
\hline & & 7 & 8 & & 9 & 10 & 11 & & 12 \\
\hline AUTOVALOR & & 1,2471 & 1,1765 & & 1,1025 & 1,0528 & 0,9794 & & 0,8591 \\
\hline \& EXPLICADA & & 0,0520 & 0,0490 & & 0,0459 & 0,0439 & 0,0408 & & 0,0358 \\
\hline \& ACUMULADA & & 0,5220 & 0,5711 & & 0,6170 & 0,6609 & 0,7017 & & 0,7375 \\
\hline
\end{tabular}

A TABELA 3 destaca os autovalores (eigenvalue) e o porcentual explicado pela análise fatorial $(35,15 \%)$. O valor MSAKMO 0.5388 ficou abaixo de 0.80 , o que significa que a amostra tem uma consistência limitada para esse tipo de análise.

Para PEREIRA (1999), o número de sujeitos recomendado em análises desse tipo seria de cinco a dez atletas para cada item da escala, no caso, de 120 a 240 atletas de handebol de alto nivel técnico de desempenho. Observou-se ainda, que TAMAYO (1989) utilizou uma amostra de 1199 sujeitos na validação fatorial da 
escala de Levenson traduzida por DELA COLETA (1987). Portanto, a análise pela medida MSA / KMO (Kaiser Méier Olkin), demonstra que o número de sujeitos é inferior aquele considerado ideal, podendo ter interferido na análise fatorial.

Uma outra possibilidade de análise fatorial consiste em pré-fixar o número de fatores, para verificar se esses se agrupam da mesma forma que em seus domínios originais. A TABELA 4, a seguir, apresenta como os itens da escala agrupam-se, fixando-se o número de fatores em três.

TABELA 4 - Análise fatorial: composição dos agrupamentos resultantes após rotação ortogonal (varimax), fixando-se o número de fatores em três

\begin{tabular}{|c|c|c|c|c|}
\hline & CARGA & & EM & SCALA MULTIDIMENCIONAL DE LÓCUS DE CONTROLE DO ESPORTE \\
\hline \multirow{9}{*}{ I } & 0,608 & LC8 & PP & $\begin{array}{l}\text { Para alcançar uma posição privilegiada no esporte, vou precisar } \\
\text { da ajuda de pessoas influentes. }\end{array}$ \\
\hline & 0,544 & LC3 & $\mathrm{PP}$ & $\begin{array}{l}\text { Se as pessoas gostam de um atleta, é porque simplesmente } \\
\text { gostam. Dai, não adiante se esforçar para ser agradável. }\end{array}$ \\
\hline & 0,540 & LC20 & $\mathrm{PP}$ & $\begin{array}{l}\text { Apesar de ter boa capacidade para o esporte, só conseguirei } \\
\text { chegar onde eu quero se tiver ajuda de pessoas importantes. }\end{array}$ \\
\hline & 0,525 & LC6 & SA & $\begin{array}{l}\text { Aqueles que tem sucesso no esporte, realmente tiveram muita } \\
\text { sorte. }\end{array}$ \\
\hline & 82 & LC15 & PP & Minha carreira no esporte depende muito de outras pessoas. \\
\hline & 30 & LC12 & SA & $\begin{array}{l}\text { Muitas coisas que afetam a carreira de um atleta acontecem por } \\
\text { acaso. }\end{array}$ \\
\hline & 0,439 & LC10 & SA & $\begin{array}{l}\text { Para ser um atleta de sucesso, depende de estar no esporte } \\
\text { certo, na equipe certa e na hora certa. }\end{array}$ \\
\hline & 0,408 & LC11 & PP & $\begin{array}{l}\text { Se eu tiver sucesso no esporte, será por causa das pessoas que } \\
\text { cuidaram da minha carreira. }\end{array}$ \\
\hline & 0,295 & LC7 & SA & $\begin{array}{l}\text { São momentos oportunos, que fazem de um atleta qualquer, um } \\
\text { super atleta. }\end{array}$ \\
\hline \multirow{9}{*}{1} & & 8 & I & $\begin{array}{l}\text { É raro encontrar um resultado de jogo injusto, } \circ \text { que existe, } \\
\text { são atletas mal preparados. }\end{array}$ \\
\hline & 0,527 & LC9 & I & $\begin{array}{l}\text { Se eu tiver sucesso na carreira esportiva, será principalmente } \\
\text { por causa da minha capacidade. }\end{array}$ \\
\hline & 3 & LC4 & I & Se eu me dedicar bastante, posso ter sucesso no esporte. \\
\hline & 4 & IC1 & I & $\begin{array}{l}\text { Para mim, a instabilidade na carreira esportiva resulta de } \\
\text { dificuldades do próprio atleta. }\end{array}$ \\
\hline & 0,486 & LC24 & $8 A$ & Se for meu destino, eu me darei bem no \\
\hline & & LC5 & $I$ & $\begin{array}{l}\text { o sucesso no esporte é questão de muito trabalho } \\
\text { persisténcia.A sorte tem pouco ou nada a ver com isso. }\end{array}$ \\
\hline & 0,348 & LC21 & $I$ & $\begin{array}{l}\text { o atleta que segue corretamente uma carreira bem planejada, } \\
\text { pode ficar tranqüilo quanto ao seu futuro. }\end{array}$ \\
\hline & 12 & LC16 & $8 \AA$ & $\begin{array}{l}\text { Durante um jogo qualquer, na hora "H", é Deus quem mostra para } \\
\text { o atleta a direção certa. }\end{array}$ \\
\hline & 242 & LC17 & $P P$ & $\begin{array}{l}\text { Na maioria das vezes, não dá para entender porque os politicos } \\
\text { agem desta ou daquela forma com relação ao esporte. }\end{array}$ \\
\hline
\end{tabular}


TABELA 4 - Análise fatorial: composição dos agrupamentos resultantes após rotação ortogonal (varimax), fixando-se o número de fatores em três (continuação)

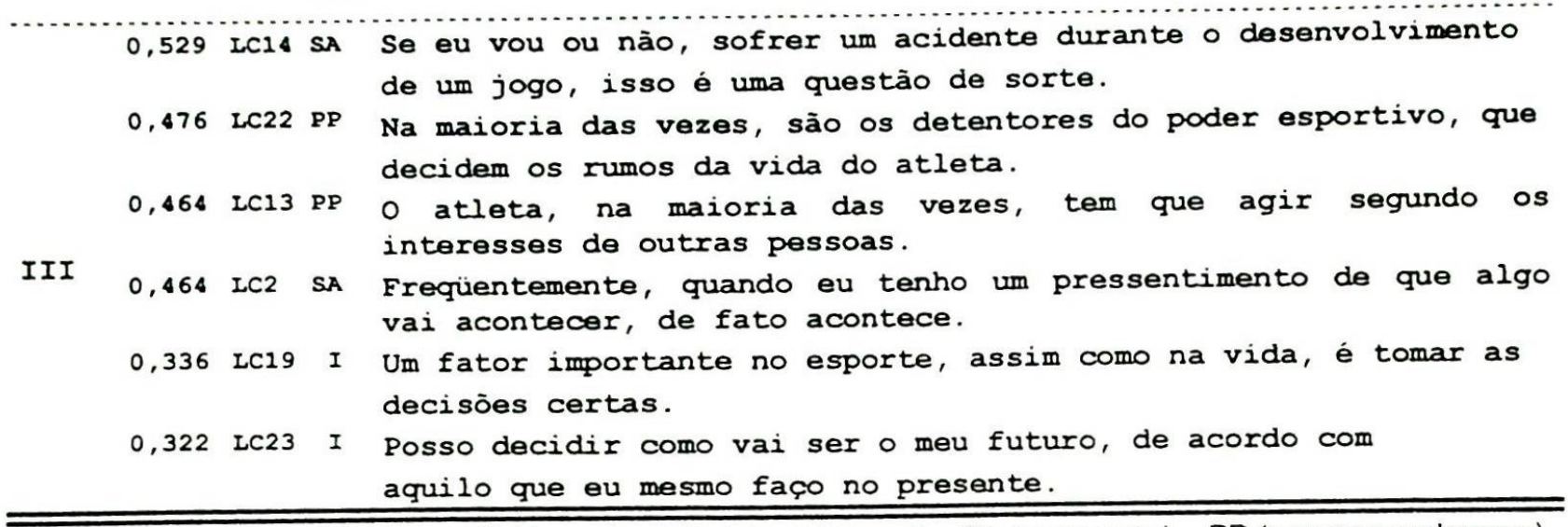

LEGENDA: LC (Iócus de controle) - I (interno) - SA (sorte-azar ) - PP (pessoas poderosas)

Os fatores destacados na TABELA 4 explicam $28,7 \%$ da variabilidade, observando-se a estrutura dos grupamentos, nota-se agrupamentos semelhantes aos definidos nos domínios originais, e o lócus de controle externo pessoas poderosas, apresentou melhor definição, em seguida, o lócus de controle interno.

TAMAYO (1989) observa que a maneira de interpretar os itens da escala de lócus de controle pode ter raizes, na importância dada pelos sujeitos à dimensão, no caso, o lócus de controle externo pessoas poderosas, no item "Para alcançar uma posição privilegiada no esporte, vou precisar da ajuda de pessoas influentes ${ }^{n}$ sugere a importância dada pelos atletas a esta questão.

A presença de overlap, justifica-se pela medida MSA/KMO 0,5388, abaixo de 0,80 o que implica em baixa consistência da amostra para esse tipo de análise, mesmo assim, revelou indícios de uma estrutura tridimensional. Evidenciando uma sólida estrutura de validação ao instrumento e seu uso particularmente recomendado, no âmbito da pesquisa básica, preferencialmente com o apoio de outros instrumentos, que possam fundamentar a aplicação prática. A escala de lócus de controle do esporte, propõem-se em avaliar de forma eficiente, fatores complexos, o que repercute na precisão do instrumento, para melhorar, seria necessário aumentar o número de itens, "validity is a matter of degree rather than an all-or-none property" NUNALLY (1970) ${ }^{11}$ citado por TAMAYO (1989).

"J. C. J. NUNALLY, Introduction to psychological measurement, New York: McGraw-Hill, 1970, p. 133. 


\section{Do projeto-piloto}

Com o objetivo de esclarecer as hipóteses e testar previamente a aplicabilidade dos instrumentos, o pesquisador desenvolveu um projeto-piloto. $A$ pré-categorização das crenças religiosas em domínios foi estabelecida em conformidade com os estudos empíricos realizados com questionário Pratt de crenças religiosas, desde de sua criação em The Psychology of Religious Belief (PRATT,1907), às pesquisas e adaptações realizadas no Brasil por FREITAS (2002).

Observa-se, entretanto, que, não tem caráter classificatório, a caracterização em dominios não é rígida, tendo apenas por objetivo criar parâmetros que permitam abordar a problemática do estudo, objetivando buscar a compreensão das possíveis relações entre lócus de controle e as crenças religiosas dos atletas.

A participação na pesquisa foi livre, informada, esclarecida, consentida, conforme o termo de consentimento (ANEXO I).

Participaram do projeto-piloto 38 atletas praticantes de Handebol de alto nivel técnico de desempenho, entre os quais os integrantes da Seleção Brasileira Olímpica Permanente de handebol, perfazendo uma amostra de 24 atletas de uma equipe masculina pertencente a um clube social e esportivo, localizado na cidade de São Paulo e 14 atletas de uma equipe feminina ligada a um clube localizado na Grande São Paulo.

A escala multidimensional do lócus de controle do esporte e o inventário Pratt de crenças Religiosas no Esporte não apresentaram problemas durante a aplicação, tendo sido respondidos entre 30 e 90 minutos.

As inferências, revelaram indícios de que a crença intelectual, caracterizada pela dúvida, associava-se a menores escores de lócus de controle interno e maiores escores de lócus de controle externo sorte-azar. O lócus ce controle externo sorteazar, também, apresentou correlação com o nivel de escolaridade superior, levantando uma série de questionamentos.

A crença emocional apresentou tendência a escores mais elevados de lócus de controle interno, interpretados como conseqüência das características deste domínio, vivencia e identificação com o divino, fonte de poder inesgotável. 
conferindo maior segurança e assertividade ao atleta em momentos críticos, resultando em maiores escores de lócus de controle interno.

Embora, o alto grau confiança associado à crença emocional, também, tenha apresentado tendência para escores mais elevados de lócus de controle externo à sorte-azar, caracterizando um movimento de busca de autoconfiança e proteção que se justificaria exatamente pela constatação da falta desses recursos, uma identificação com uma fonte de grande poder; no entanto, fora do controle do atleta, uma força que poderia ser sentida, porém não controlada, por isto também, associada ao lócus de controle externo sorte-azar.

Os resultados obtidos no projeto-piloto levaram a inferências sobre a importância dos conceitos definidos sobre lócus de controle no âmbito da Teoria da Aprendizagem Social, como referência importante ao treinamento psicológico dos atletas em torno de estratégias cognitivas e fenomenológicas, para a educação do lócus do controle.

O desenvolvimento do projeto-piloto foi de fundamental importância para testar a aplicabilidade dos instrumentos, contribuindo para focar a pesquisa e formular novas hipóteses.

No sentido de verificar se as mesmas tendências, seriam mantidas no estudo final, e em razão do fato dos atletas estarem constantemente em viagens ou concentrados aos Jogos Olimpicos 2004, realizados durante o mês de agosto e setembro em Atenas, decidiu-se por incorporar os dados colhidos no projeto-piloto ao estudo final.

\section{APRESENTAÇÃO DOS RESULTADOS}

De acordo com os planos da pesquisa, a exemplo do projeto-piloto, os dados foram colhidos na região de São Paulo e Grande São Paulo, sendo sete equipes de handebol, quatro femininas $N=53$ e três masculinas $N=58$ totalizando 111 atletas representativos do mais alto nivel técnico do handebol brasileiro, incluindo-se as bases da seleções feminina e masculina que participaram dos Jogos Olímpicos da Grécia 2004. O que conferiu uma condiçäo peculiar ao estudo, pelo fato da amostra 
constituir-se por sujeitos que se ocupavam da maximização do desempenho. visando aos jogos Olimpicos, que pela primeira vez na história desse esporte no Brasil, reuniu às equipes feminina e masculina, ouro nos jogos Pan Americano de 2004 realizados em San Domingo.

As caracteristicas de natureza sociotécnicas abstraidas da ficha de identificação que acompanha os instrumentos, revelou dados importantes no estabelecimento das relações múltiplas entre as variáveis independentes do estudo: domínios lócus de controle interno, lócus de controle externo sorte-azar e lócus de controle externo pessoas poderosas, e características das crenças religiosas dos atletas.

Descritivamente, as características de natureza sociotécnicas como: idade, sexo, naturalidade, nivel de escolaridade e a posição ocupada pelos atletas nas equipes, são apresentadas na forma de figuras e tabelas de freqüência.

As variáveis contínuas são mostradas com medidas de posição e dispersão: média, desvio-padrão, valores mínimos e máximos.

No tratamento estatístico foi utilizada a análise de variância simples one way anova ${ }^{12}$ e o teste post-hoc de turkey ${ }^{13}$ para a comparação das médias, o nivel de significância adotado aos testes estatísticos é de $5 \%(p<0,05)$.

\subsection{Características sociotécnicas dos sujeitos da pesquisa}

Em razão dos enfoques de natureza subjetiva e cognitiva das crenças religiosas e lócus de controle, é necessário caracterizar o perfil dos atletas que compõem a amostra desse estudo. Nesse sentido, os porcentuais de distribuição de freqüência de suas idades nas equipes feminina e masculina, são destacados na FIGURA 6.

\footnotetext{
12 One-way anova: teste clássico utilizado para comparação múltipla das médias dos escores de lócus de controle nos trés domínios: lócus de controle: interno, externo-acaso e externo pessoas poderosas com os dominios de crenças religiosas: primitiva, emocional, intelectual e ético-moral.

${ }^{13}$ Teste post-hoc de Tukey: Utilizado para comparaçáo múltipla de médias
} 


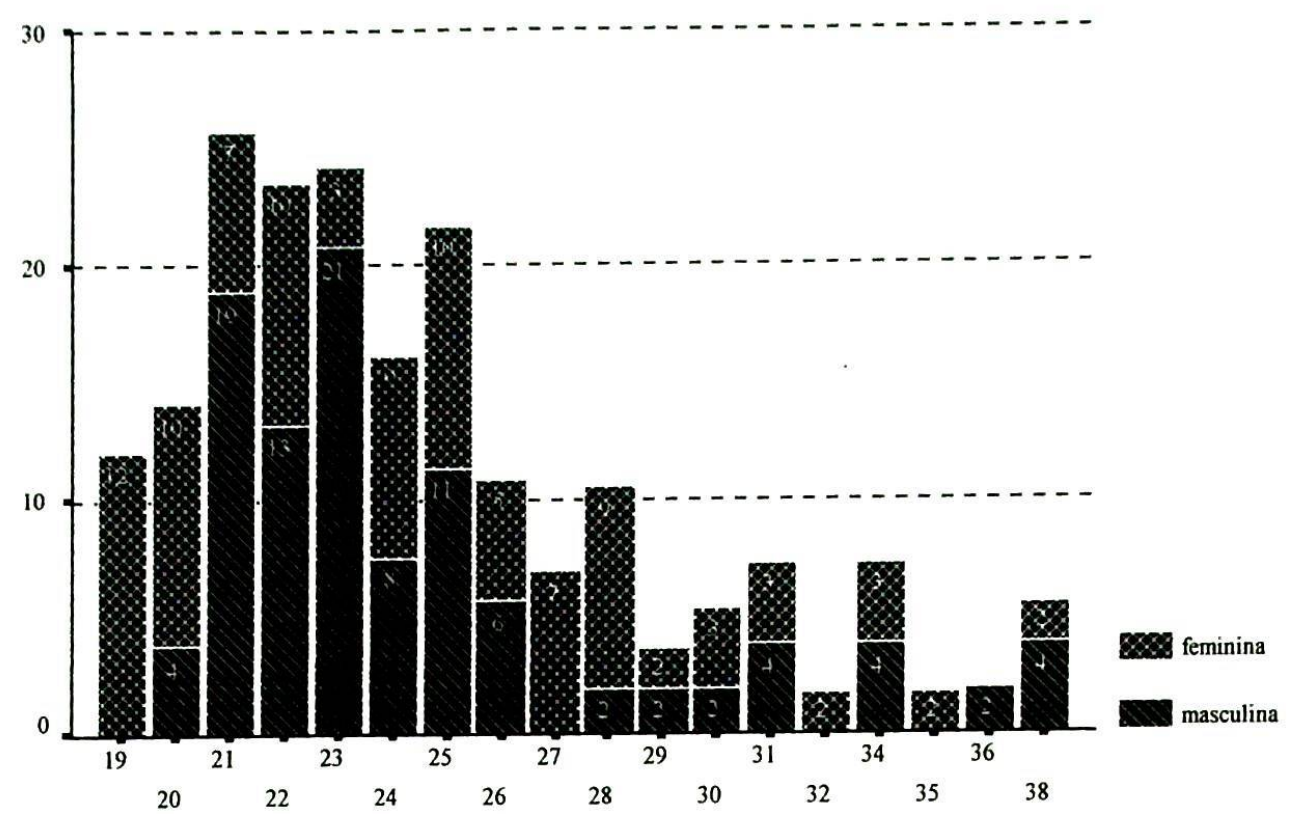

FIGURA 6 - Valores porcentuais de distribuição de freqüência das idades dos atletas nas equipes femininas e masculinas

Pela distribuição de freqüência das idades dos atletas na FIGURA 6 nota-se que não houve diferenças significativas. A média geral das idades é de 24,74 . Notase apenas que há uma grande amplitude entre a idade mínima 19 e máxima 38, por isso nas correlações com as demais variáveis a idade foi considerada em faixas como demonstrado na TABELA 5

TABELA 5 - Distribuição geral da idade dos atletas de handebol de alto rendimento por faixas etárias

\begin{tabular}{llrrrr}
\hline \hline & & FREQÜENCIA & PORCENTAGEM & \% ACUMULADA \\
\hline IDADE & $<20$ & 7 & 6,3 & 6,3 \\
& $20-24$ & 57 & 51,4 & 57,7 \\
& $25-29$ & 30 & 27,0 & 84,7 \\
& $30-34$ & 12 & 10,8 & 95,5 \\
& $>35$ & 5 & 4,5 & 100,0 \\
& Total & 111 & 100,0 & \\
&
\end{tabular}

Quanto à naturalidade, detectou-se a presença de atletas originários de diversos estados brasileiros e dois estrangeiros. Os dados relativos à naturalidade $\mathrm{e}$ nacionalidade dos atletas são destacados na TABELA 6. 
TABELA 6 - Distribuição das freqüências absolutas e porcentuais relativos à naturalidade e nacionalidade dos atletas do handebol de alto rendimento

\begin{tabular}{ll}
\hline \hline & PORCENTAGEM \\
\hline NATURALIDADE & 46 \\
SIO DE JANEIO & 11 \\
RIO GRANDE DO SUL & 11 \\
SANTA CATARINA & 11 \\
PARANA & 9 \\
MINAS GERAIS & 5 \\
GOIAS & 3 \\
BAHIA & 2 \\
MARANHĀO & 2 \\
PARAIBA & 2 \\
PARA & 1 \\
CEARA & 1 \\
PERNANBUCO & 1 \\
RONDONIA & 1 \\
DISTRITO FEDERAL & 1 \\
MATO GROSSO DO SUL & 1 \\
RIO GRANDE DO NORTE & 1 \\
ARGENTINA & 1 \\
CUBA & 1 \\
TOtal & 1 \\
\hline
\end{tabular}

Na TABELA 6 os dados mostram que a amostra desse estudo é composta por atletas originários de 16 Estados da federação brasileira, além de um atleta cubano e um argentino, conferindo ao estudo certa abrangência, podendo-se citar que a amostra abrange representantes do esporte no Brasil.

Entretanto, excetuando-se os atletas do Rio grande do Sul (11\%) todos os outros atletas residem na cidade de São Paulo e Grande São Paulo, 46\% são originários e $43 \%$ de outras localidades, denotando que os critérios utilizados para a seleção e permanência dos atletas nas equipes de alto rendimento extrapolam a proximidade geográfica, inferindo em uma grande diversidade religiosa e cultural na amostra. Dados relativos ao nivel de escolaridade dos atletas, são destacados na TABELA 7. 
TABELA 7 - Distribuição das freqüências absolutas e porcentuais relativos ao nivel de escolarização dos atletas de handebol de alto rendimento

\begin{tabular}{llrr}
\hline \hline & & Freqüéncia & Porcentual \\
\hline NIVEL DE & MÉDIO & 23 & 20,7 \\
ESCOLARIDADE & UNIVERSITARIO & 88 & 79,3 \\
& Total & 111 & 100,0 \\
& & & \\
\hline \hline
\end{tabular}

Na TABELA 7, é surpreendente a constatação que $88 \%$ dos atletas possuem nível de escolaridade superior e $20,7 \%$ nível médio e não foram identificados entre os respondentes, atletas com nivel de primeiro grau do ensino fundamental. De certa forma, estes dados garantem uma melhor qualidade para as respostas, pela suposição de que um maior grau de qualificação escolar, implica melhor compreensão das questões apresentadas nos instrumentos, apesar dos esforços realizados, objetivando tornar a linguagem o mais simples possivel, tendo em vista torná-lo acessivel a atletas de primeiro grau do ensino fundamental.

GAMA (1990) constatou que entre os jogadores de futebol profissional de grandes e pequenos clubes brasileiros $26,22 \%$ dos atletas possuíam nivel superior, $51,31 \%$ segundo grau e $20,87 \%$ primeiro grau. Esses dados mostram diferenças significativas de escolarização entre atletas praticantes de futebol profissional (cujas bases são tradicionalmente os clubes) e 0 handebol de alto nivel técnico de desempenho, cujas bases são as escolas, aproximando o handebol, do protótipo americano de esporte, essencialmente ligado às escolas e universidades.

Estes fatos evidenciam que o esporte, além das discussões sobre formação de caráter, comporta um sentido pedagógico, já que propõe um desafio que exige habilidade, força, estratégias e equilíbrio emocional para superá-lo - a inteligência em seu sentido mais amplo.

$\mathrm{Na}$ ficha de identificação dos instrumentos, constam informações sobre as religiőes dos atletas, revelando que $99,1 \%$ acreditam em Deus.

No que tange a questão sobre a religião dos atletas, os dados são destacados na FIGURA 7. 
CATOLICA

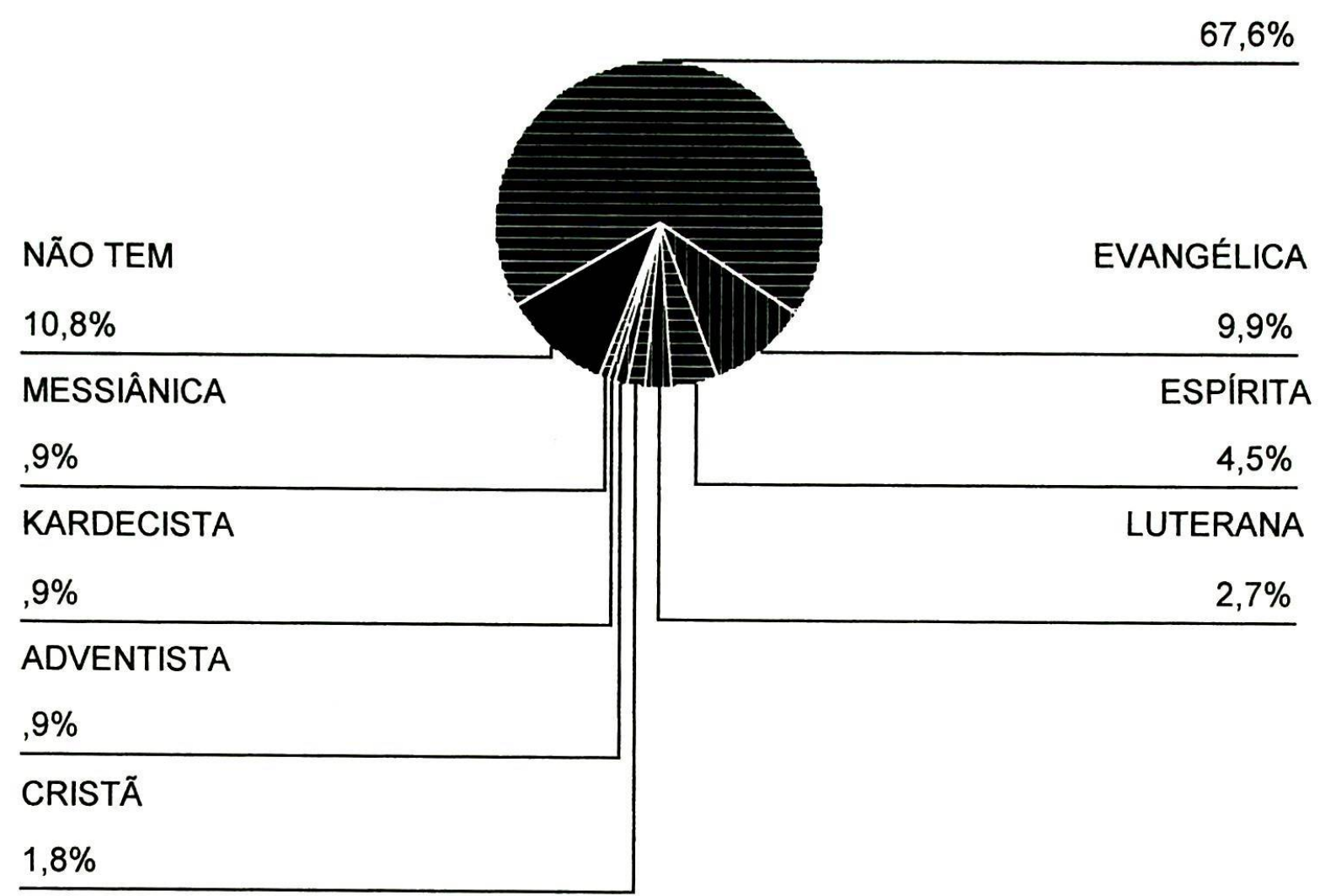

FIGURA 7 - Descrição porcentual das religiões dos atletas de handebol

Contrastando com o porcentual de atletas $(99,1 \%)$ que declararam acreditar em Deus; pelos dados apresentados na FIGURA 7 a religião predominante entre os atletas de handebol é a católica $67,6 \%$; e o segundo maior grupo é formado por atletas que declaram que não ter religião $10,8 \%$; em seguida os evangélicos $9,9 \%$; luteranos $2,7 \%$; cristãos $1,8 \%$; adventistas do sétimo dia $0,9 \%$ e kardecistas $0,9 \%$.

Chama atenção o fato do segundo maior grupo ser formado por atletas que declararam não ter religião (10,8\%), incidência $45 \%$ maior que nos dados divulgados pelo INSTITUTO BRASILEIRO DE GEOGRAFIA E ESTATÍSTICA (2000). O fato reforça a hipótese central de que as categorias de crenças religiosas, primitiva, intelectual, emocional e ético-moral podem ser caracterizadas, mediante a 
representação que os atletas fazem sobre a figura de Deus e seus sentimentos de espiritualidade no meio esportivo.

Os dados obtidos sobre as crenças religiosas dos atletas, caracterizadas pelo inventário Pratt de Crenças religiosas do esporte são, apresentados no CAPITULO 9. Dando seqüência, à apresentação dos dados abstraídos da ficha de identificação dos instrumentos, porcentuais relativos aos postos assumidos pelos atletas nas equipes esportivas pesquisadas são destacadas na FIGURA 8.

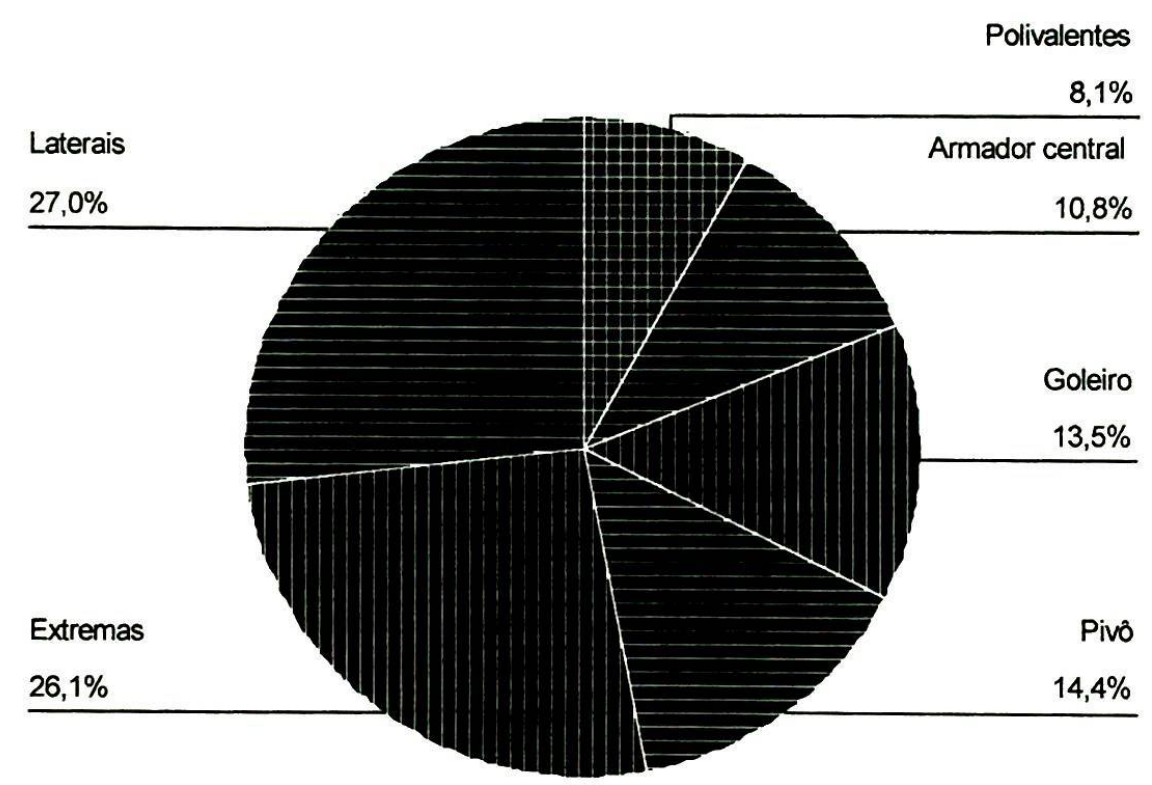

FIGURA 8 - Porcentuais referentes às posiçōes ocupadas pelos atletas na equipes pesquisadas

O handebol é um jogo caracterizado por duas equipes compostas por sete jogadores cada, que buscam por meio de passes de mão obter o gol. Conforme disponibilizados na FIGURA 8, os atletas que jogam nas laterais-esquerda e direita $(27,0 \%)$, foram agrupados objetivando facilitar cruzamentos posteriores dos dados. Assim como os atletas que atuam nas posições extrema esquerda e direita $(26,1 \%)$. Completando a amostra, os pivôs (14,4 \%); goleiros (13,5\%); armadores centrais $(10,8 \%)$ e jogadores polivalentes $(8,1 \%)$ atletas que assumem mais de um posto na 
equipe, contrapondo-se a uma acentuada tendência à especialização das funções no handebol de alto nivel técnico de desempenho, sob a denominação polivalente encontram-se atletas que ocupam, respectivamente, as funções de armador central, extrema direita e extrema esquerda; pivô e armador lateral esquerda; pivô e extrema direita.

\subsection{Resultados obtidos com a Escala multidimensional do lócus de controle do esporte}

A seguir, são apresentados os dados obtidos pela aplicação da escala de locus de controle do esporte nos atletas de handebol de competição e alto nível de desempenho técnico.

As tabelas estáticas descritivas das médias, desvios-padrões, valores minimos e máximos sobre a variação dos niveis de respostas na escala likert pictográfica, como também, as tabelas de freqüência, porcentual e distribuição das respostas em cada um dos pontos da escala likert pictográfica nos domínios de lócus de controle interno, externo sorte-azar e externo pessoas poderosas são apresentadas nos APÊNDICES XXVI, XXVII, XVIII e XXIX.

A metodologia de correção adotada para a escala multidimensional do lócus de controle consiste na soma dos valores atribuidos a cada um dos niveis da escala likert pictográfica $(-3,-2,-1,1,2,3)$ adicionando-se a constante 24 , portanto, os níveis de lócus de controle interno ( $L C I)$, controle externo sorte-azar (LCE SA) e controle externo pessoas poderosas (LCE PP) variam entre zero e 48.

Os testes de normalidade de Shapiro-Wilk ${ }^{14}$ realizados para a subescala multidimensional do lócus de controle interno ( $\mathrm{LCl}: w=0,975 ; p=0,2421)$; lócus de controle externo sorte- azar (LCE AS: $w=0,979 ; p=0,4221$ ) e lócus de controle externo pessoas poderosas (LCE PP: $w=0,975 ; p=0,2674$ ) indica distribuição normal dos escores nos três domínios da escala multidimensional do lócus de controle do esporte.

\footnotetext{
14 o teste Shapiro-Wilk testa a hipótese de a amostra pertencer a uma população normal.
} 
Histogramas de freqüenncias, variação de escores e curva normal de distribuição dos escores de lócus de controle interno, externo sorte-azar e externo pessoas poderosas são apresentados nos APÊNDICES XXX, XXXI e XXXII.

Pelos dados obtidos no teste de confiabilidade - cálculo do alfa Crombach (CAPITULO 7.6.4); pela análise fatorial (CAPITULO 7.6.5); o teste de normalidade de Shapiro-Wilk e as curvas de distribuição normal (APÊNDICES XXX, XXXI e XXXII), há evidencias, apesar do número de sujeitos ter sido considerado crítico para determinadas análises, que a Escala a Multidimencional de lócus de Controle do Esporte constitui-se em um instrumento eficaz comparativamente a outras escalas e eficiente pela simplicidade com que aborda um fenômeno considerado importante por muitos pesquisadores.

Os escores de lócus de controle interno (LCI); externo sorte-azar (LCE SA) e externo pessoas poderosas (LCE PP), valores mínimos e máximos, médias, medianas e desvio-padrão são apresentados resumidamente, destacados na TABELA 8.

TABELA 8 - Lócus de controle: médias, medianas, desvios padrão, valores mínimos e máximos obtidos pelos atletas de handebol de alto nivel técnico de desempenho

\begin{tabular}{|c|c|c|c|c|}
\hline & & $\mathrm{LCl}$ & LCE S-A & LCE PP \\
\hline $\mathrm{N}$ & casos validos & 111 & 111 & 111 \\
\hline Média & & 33,32 & 24,27 & 24,11 \\
\hline Mediana & & 34,00 & 24,00 & 24,00 \\
\hline Desvio Padrão & & 5,23 & 7,47 & 6,97 \\
\hline Valor minimo & & 17 & 8 & 8 \\
\hline Valor máximo & & 44 & 44 & 42 \\
\hline
\end{tabular}

Os resultados apresentados pela TABELA 8 demonstram que o domínio lócus de controle interno é o que apresentou os maiores escores (média $L C l=33,32$ ), externo sorte-azar (média LCE S-A $=24,27$ ) e externo pessoas poderosas (média $L C E P P=24,11$ ). Inferindo-se que a internalidade é a caracteristica predominante ao 
lócus de controle dos atletas de handebol de alto nivel técnico de desempenho. Revelando habilidades psicológicas e comportamentais compativeis ao alto nivel técnico de desempenho, entretanto é preciso investigar as relações que se estabelecem entre os escores de lócus de controle e demais variáveis, assim como, o impacto desse fator, em estudos futuros, na saúde psíquica e desempenho dos atletas, dado que as derrotas tendem a ser vivenciadas mais intensamente para atletas com orientação ao lócus interno, dado que atletas com tendência à de externalidade tendem a identificar fora a causa para as derrotas e vicissitudes do esporte.

ROMERO-GARCIA e MALDONADO (1985) ${ }^{15}$ citados por TAMAYO (1989) propõem uma formula ao cálculo do escore total de internalidade (IT), uma variável derivada ao lócus de controle que relaciona o interno (I) ao externo sorte-azar (SA) e externo pessoas poderosas (PP).

$$
I T=1-(S A+P P) / 2
$$

O calculo do índice de internalidade pelos valores médios de lócus de controle para os atletas de handebol apresentou o valor IT $=9,13$, dado que pode constituirse como variável alternativa na avaliação ao lócus de controle interno, dada a tendência para escores mais elevados (média $L C l=33,32$; $\min .17$ e max. 44)

De acordo com a maior parte dos especialistas, escores muito elevados de lócus de controle externo sorte-azar, são incompativeis ao sucesso nas mais diversas esferas da atividade humana.

Quanto ao lócus de controle externo pessoas poderosas no esporte, a introdução desse instrumento poderá permitir análises referentes à representação do atleta em face dos árbitros, relacionamento com o técnico e equipe, pela suposição de que valores muito elevados ou baixos de lócus de controle externo pessoas poderosas possam ajudar a detectar problemas com faltas, relacionamento com o técnico e coesão das equipes.

is O. ROMERO-GARCIA; P. MALDONADO, Escala Levenson de locus de control: analisis fatorial em Venezuela, Mérida: Laboratorio de Psicologia 


\subsection{Resultados obtidos com o Inventário Pratt de crenças religiosas no esporte (IPCRE)}

Objetivando esclarecer as hipóteses são apresentados e analisados os principais resultados obtidos pela aplicação do Inventário Pratt de crenças religiosas no esporte, a fim de se possa estabelecer as correlaçōes entre as variáveis em análise. As modalidades de crenças religiosas, abstraídas dos conceitos empíricos e teóricos PRATT (1907, 1923), FREITAS (2002) crença primitiva, intelectual, emocional e ético-moral, refletiram-se nas três primeiras questões do inventário sobre crenças religiosas no esporte sob a forma de alternativas de múltipla escolha, foi facultado aos atletas optar por mais de uma alternativa, assim como pela opção outro significado, e a solicitação de justificar as repostas.

A primeira questão do instrumento define as alternativas de crença religiosa com base na representação de Deus sob a perspectiva da religião, Objetivando verificar se as crenças religiosas dos atletas se definem em torno do modelo empírico teórico postulado, foram analisadas as justificativas das respostas nas quais, os atletas não optaram por nenhuma alternativa, pela alternativa outro significado e ou mais de uma modalidade de crenças. Os resultados da análise obtidos nesse processo, são destacados no QUADRO 7.

QUADRO 7 - Análise das respostas sobre outros significados para as crenças Religiosas, na questão: $O$ que a religião significa para você ? É ...

\begin{tabular}{|r|r|l|r|}
\hline Atleta & Outras & \multicolumn{1}{|c|}{ Justificativa } & Crença \\
\hline 35 & O & $\begin{array}{l}\text { A fé. A fé em algo que traz segurança e paz, amor e } \\
\text { esperança.A busca. A busca para a felicidade, } \\
\text { tranqüilidade, harmonia e estabilidade durante a vida. }\end{array}$ & Intelual \\
\hline 47 & O $\begin{array}{l}\text { Uma noção pessoal do indivíduo consigo mesmo. } \\
\text { Religião para mim funciona como uma outra parte dos } \\
\text { meus princípios, da minha base. Acho que é o que dá } \\
\text { sustentação ao indivíduo, sem familia e religião (fé) o } \\
\text { indivíduo não tem chão. }\end{array}$ & $\begin{array}{c}\text { moral } \\
\end{array}$ \\
\hline
\end{tabular}


QUADRO 7 - Análise das respostas sobre outros significados para as crenças

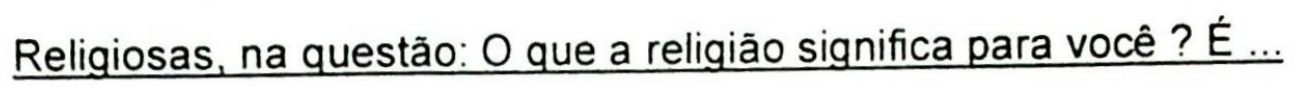

(continuação)

\begin{tabular}{|c|c|c|c|c|c|}
\hline Atleta & \multicolumn{3}{|c|}{ Outras } & Justificativa & Crença \\
\hline 57 & & & $\mathrm{O}$ & $\begin{array}{l}\text { Saber que uma força maior criou isto, tudo é regido } \\
\text { perfeitamente. }\end{array}$ & Emocional \\
\hline 66 & & $\mathrm{I} E$ & & $\begin{array}{l}\text { Acredito em Deus porque foi uma coisa que minha } \\
\text { família me passou e acho que é uma coisa, principio } \\
\text { correto e por isso acredito }\end{array}$ & Intelectual \\
\hline 70 & & $I E$ & & Energia & Emocional \\
\hline 88 & & & & & Em branco \\
\hline 91 & & & $\mathrm{O}$ & $\begin{array}{l}\text { Para mim, religião é a sua dedicação a Deus, e a maneira } \\
\text { que você comporta-se perante ele }\end{array}$ & Primitiva \\
\hline 92 & & & $\mathrm{O}$ & Amar Deus sobre todas as coisas & Primitiva \\
\hline 99 & & & & $\begin{array}{l}\text { São varias experiências que faz eu acreditar na minha } \\
\text { religião e respeitar as minhas tradições que me são } \\
\text { ensinadas desde quando eu nasci }\end{array}$ & Primitiva \\
\hline 100 & & & $\mathrm{O}$ & Acreditar na reencarnação & Outra \\
\hline 107 & & & $\mathrm{O}$ & $\begin{array}{l}\text { Agradecer pelas coisas boas que acontecem e pedir } \\
\text { proteção, ajuda, saúde }\end{array}$ & Intelectual \\
\hline 109 & & & $\mathrm{O}$ & A natureza é Deus !!! & Emocional \\
\hline 110 & & & $\mathrm{O}$ & $\begin{array}{l}\text { Uma crença que eu tenho que me ajuda e me faz me } \\
\text { sentir bem }\end{array}$ & Primitiva \\
\hline
\end{tabular}

Legenda: $P=$ primitiva; $I=$ Intelectual; $I E=$ emocional; $E=$ ético-moral; $O=$ outra

Os dados sobre as crenças religiosas dos atletas no QUADRO 7 mostram que, apesar da natureza ambigua de determinadas respostas denotando um entrelaçamento entre os niveis de crença em análise, é possivel definir uma tendência na maioria das respostas para uma das modalidades de crença religiosa, no contexto especifico do esporte.

A resposta do atleta de número 100 , não foi caracterizada, pelo fato desse atleta ter declarado que não acredita em Deus e não tem religião, embora posteriormente no contexto das questões formuladas pelo instrumento, tenha admitido que faz uma oração budista, antes do inicio das partidas. Desta forma, a 
justificativa não foi caracterizada por de denotar o motivo pelo qual não acredita em Deus e não ter religião.

A resposta do atleta 100 "Acreditar na reencarnação", poderia ser caracterizada como primitiva, caso estivesse se referindo não-aceitação da reencarnação, como um fato dado (sem questionamento) ou de natureza emocional caso esteja se referindo à reencarnação, como forma possessão, em alusão à experiências religiosas vivenciadas em diversos cultos que se estendem desde a Antiguidade, passando pela espiritualidade na Grécia Clássica aos dias atuais.

Os dados porcentuais descritivos dos domínios de crenças religiosas dos atletas de handebol, pautado na representação de Deus sob as perspectiva da religião, são destacados nos dados da FIGURA 9.

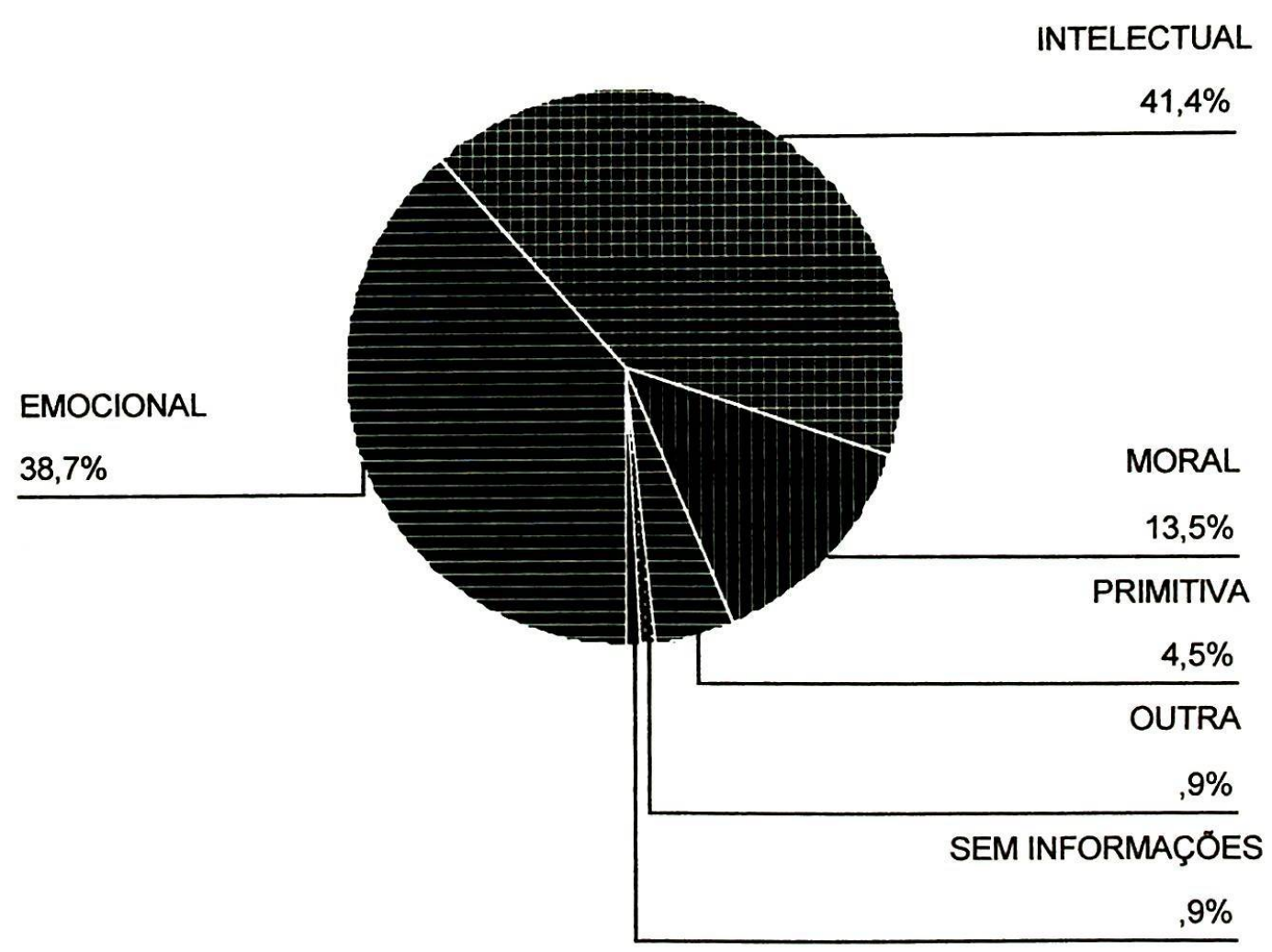

FIGURA 9 - Descrição das crenças dos atletas, sob as perspectiva: 0 que a religião significa para você pessoalmente ? É ... 
Os dados da FIGURA 9 demonstram que sob a perspectiva da religião a representação de Deus aos atletas de handebol caracteriza-se pela crença intelectual $41,4 \%$, uma modalidade de crença conceitualmente identificada pelo conflito, pela dúvida, pelo ceticismo, e pela busca de sentido e explicações racionais para a origem e destino último do homem.

Resultado, consistente pela constatação de que $99,1 \%$ dos atletas declararam acreditar em Deus, frente ao grande porcentual dos que declararam-se sem religião $(10,8 \%)$, dado que segue a mesma tendência de aumento, verificada no censo demográfico da população brasileira, em que o número de pessoas sem religião aumentou de 4,7\%, em 1991, para $7,28 \%$ em 2000 e $10,8 \%$ na amostra desse estudo.

Dando seqüência ao modelo de análise das justificativas sobre "outros significados" para as crenças religiosas; na segunda questão do inventário, que busca caracterizar as alternativas de resposta, segundo a representação do atleta sobre a figura de Deus e objetivando verificar se essas justificativas se definiriam em torno das modalidades construídas, pautado na obra de J. B. Pratt, as respostas dos atletas para outros significados e ou mais de uma modalidade de crença religiosa foram analisadas e os resultados obtidos nesse processo, são destacados no QUADRO 8

QUADRO 8 - Análise das respostas sobre outros significados para as crenças religiosas, de acordo com o modelo empírico teórico de J. B. Pratt, na questão: Como é Deus para você ?

\begin{tabular}{|c|c|c|c|}
\hline Atleta & Outras & Justificativa & Crença \\
\hline 17 & I & $\begin{array}{l}\text { Sem Deus minha vida fica sem rumo, sem sentido e a } \\
\text { minha vida fica vulnerável à ação do inimigo }\end{array}$ & Intelectual \\
\hline 34 & $E \quad \dot{E}$ & $\begin{array}{l}\text { A energia que sinto é quando me concentro, quando } \\
\text { estou com mau humor, e começo a me sentir melhor } \\
\text { mais positiva para tudo. Penso em coisas boas, amor, } \\
\text { paz, amizades etc }\end{array}$ & Emocional \\
\hline
\end{tabular}


QUADRO 8 - Análise das respostas sobre outros significados para as crenças religiosas de acordo com o modelo empirico teórico de J. B.

Pratt, na questão: Como é Deus para você ?(continuação).

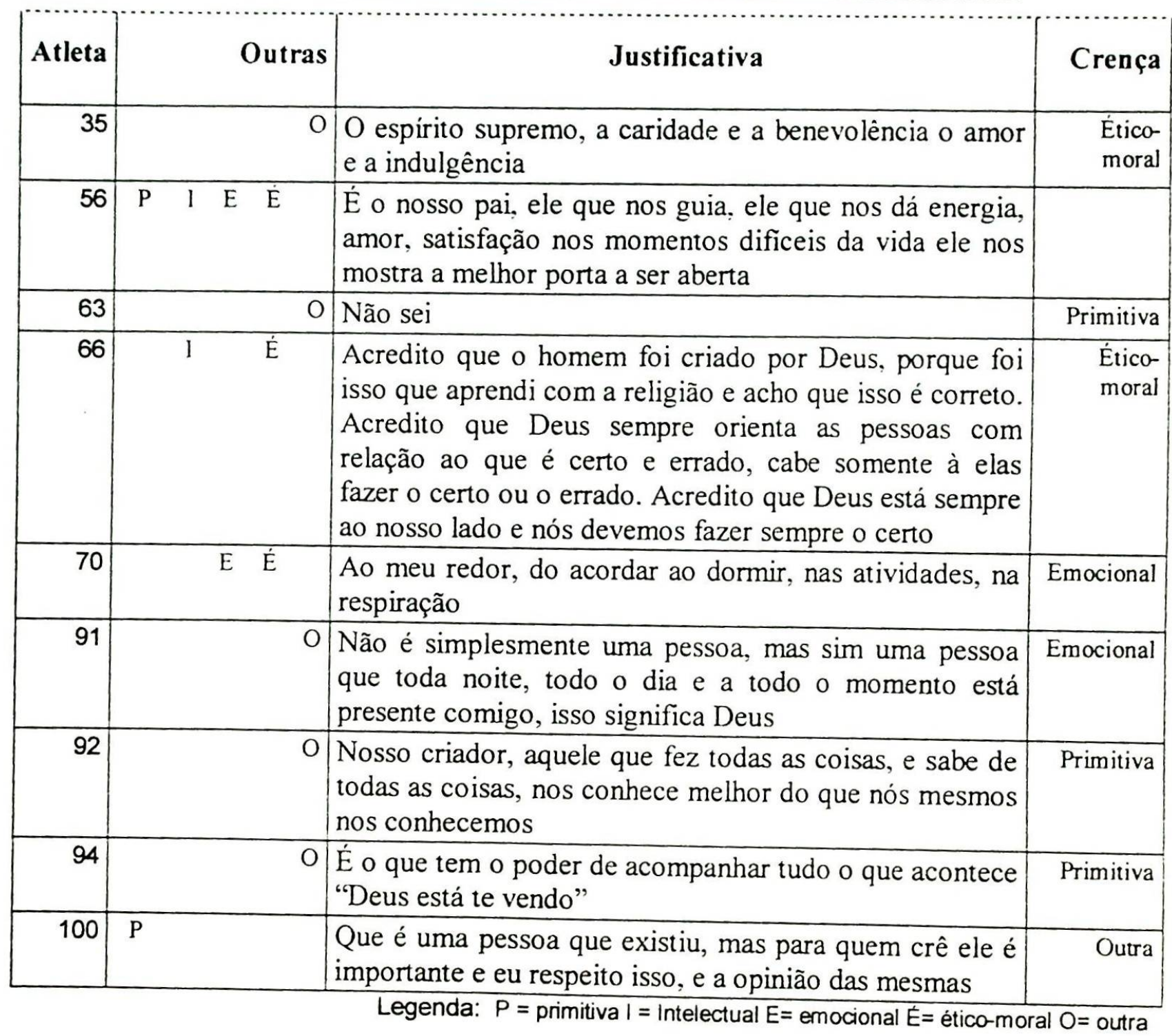

No QUADRO 8, foi possivel agrupar a maior parte das respostas de acordo com os postulados do instrumento. $O$ caso 100 , não foi caracterizado, pelos motivos já expostos anteriormente, no entanto, deixa transparecer um motivo de natureza intelectual para a não crença "Que é uma pessoa que existiu, mas para quem crê, ele é importante e eu respeito isso, e a opinião das mesmas" , demonstrando ao mesmo tempo, uma atitude de respeito à crença religiosa dos outros atletas.

Dados descritivos das crenças dos atletas, com base na representação de Deus ao atleta são destacados na FIGURA 10. 


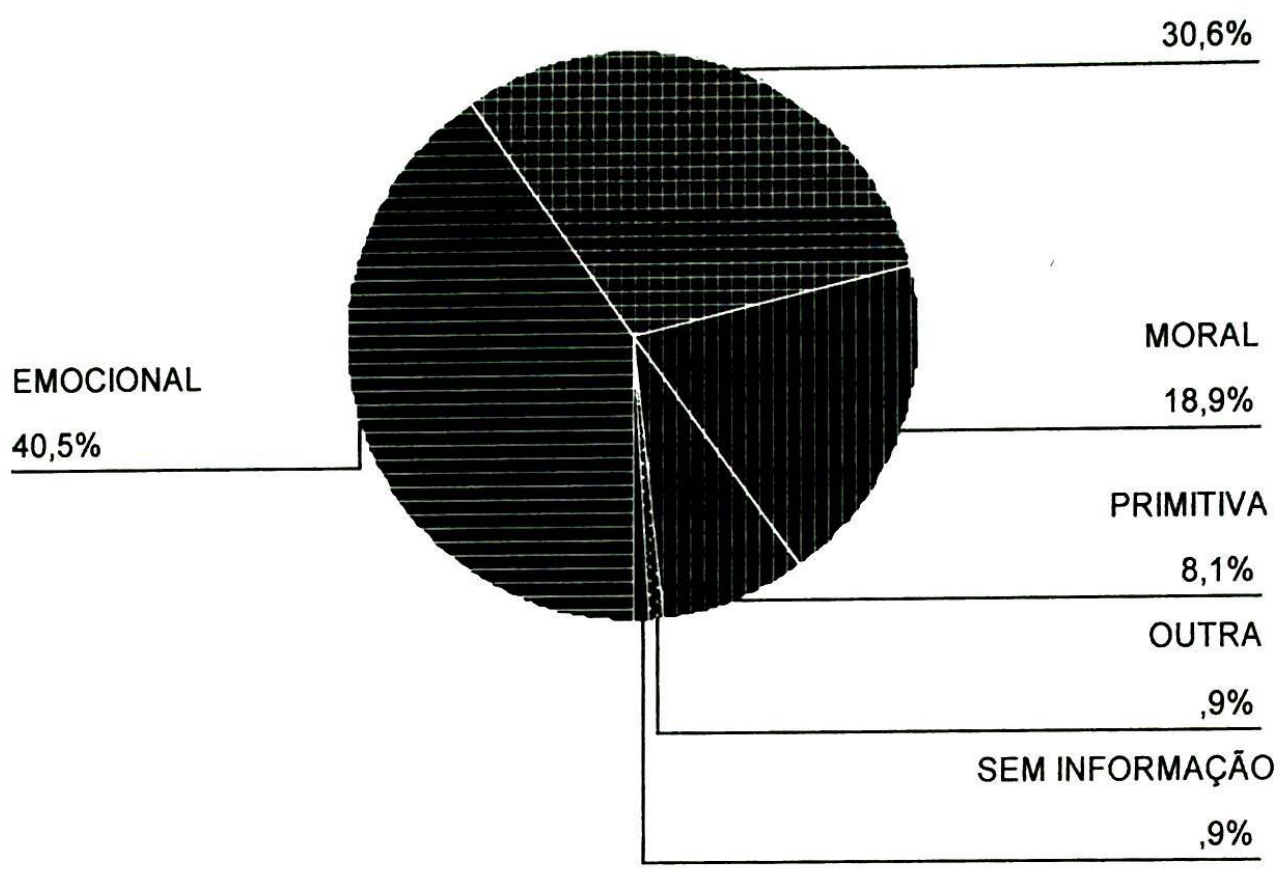

FIGURA 10 - Descrição das crenças dos atletas, sob as perspectiva: Como é Deus para você?

Pela FIGURA 10, é possível observar que as características gerais delineadas na questão anterior mantiveram-se, porém há uma inversão e a crença emocional $(40,5 \%)$ aparece em primeiro lugar, em seguida, vem à crença intelectual, $30,6 \%$. Nesse processo aumento à crença ético-moral $(18,9 \%)$, denotando uma conexão das crenças dos atletas aos valores éticos, cujas justificativas de resposta evidenciam o esporte como um modelo positivo aos jovens, exemplo de postura de vida, fonte de esperança e motivação para superar as dificuldades.

Por outro lado, a dimensão ético-moral, também, foi rejeitada por parte dos atletas, com base em justificativas de fundo ético, por considerar que o uso de violência, atitudes antiéticas, o vencer a qualquer custo é incompativel.

Finalizando, a terceira questão do inventário define as alternativas de resposta, segundo os motivos em que se sustentam as crenças em Deus. Os resultados obtidos pela análise são apresentados no QUADRO 9. 
QUADRO 9 - Análise das respostas sobre outros significados para as crenças religiosas de acordo com o modelo empírico teórico de J. B. Pratt na questão: Como é Deus para você ?

\begin{tabular}{|c|c|c|c|c|c|}
\hline Atleta & \multicolumn{3}{|c|}{ Outras } & Justificativa & Crença \\
\hline 8 & & $1 \mathrm{E}$ & $\mathrm{O}$ & Eu simplesmente acredito em Deus & Primitiva \\
\hline 11 & $\mathrm{P}$ & $\mathrm{M}$ & & Na Biblia & Primitiva \\
\hline 13 & & & & $\begin{array}{l}\text { Eu acredito porque é minha fé, minha luz e meu } \\
\text { caminho. Ele me ensina e me mostra as coisas }\end{array}$ & Emocional \\
\hline 33 & & $\mathrm{E}$ & $\mathrm{O}$ & $\begin{array}{l}\text { A experiência de sentir Deus é uma alegria, calma, } \\
\text { felicidade, prazer, amor, paz interior que não tem } \\
\text { explicação ... Deus é tudo em todos os lugares }\end{array}$ & Emocional \\
\hline 34 & $P$ & $E$ & & $\begin{array}{l}\text { Quando leio o livro sagrado (é muito dificil) ou quando } \\
\text { faço uma oração me sinto melhor mais leve }\end{array}$ & Emocional \\
\hline 35 & & & $\mathrm{O}$ & $\begin{array}{l}\text { Esse é um mistério que a humanidade carrega através dos } \\
\text { anos. Nenhuma resposta convence, nenhum fato verídico } \\
\text { convence. As coisas acontecem diante dos olhos das } \\
\text { pessoas e elas fecham para não ver, por que se } \\
\text { perguntam: Como posso crer no que não vejo? O } \\
\text { evangelho de cristo nos ensina, nos mostra, faz refletir e } \\
\text { tirar conclusões. }\end{array}$ & Intelectual \\
\hline 38 & & & $\mathrm{O}$ & $\begin{array}{l}\text { Não acredito em um Deus, mas sim em uma força } \\
\text { superior }\end{array}$ & Emocional \\
\hline 39 & & & $\mathrm{O}$ & $\begin{array}{l}\text { Acredito em Deus, porque alguém deve ter começado a } \\
\text { vida, e esta cuidando de nós }\end{array}$ & Intelectual \\
\hline 41 & & & $\mathrm{O}$ & Acredito pois tenho Fé & Emocional \\
\hline 46 & & & & & Em branco \\
\hline 53 & & & $\mathrm{O}$ & Por causa da energia presente no universo & Emocional \\
\hline 60 & & & $\mathrm{O}$ & $\begin{array}{l}\text { Eu acredito porque quando nasci, fui batizado em igreja } \\
\text { católica (não sou praticante), mas em virtude de todas as } \\
\text { evidências que estão presentes e de toda a força que esse } \\
\text { "movimento" tem, não creio que isso possa ser irreal }\end{array}$ & Intelectual \\
\hline 62 & & & $\mathrm{O}$ & $\begin{array}{l}\text { Cada um deve procurar seu Deus interior e ter suas } \\
\text { próprias crenças }\end{array}$ & Intelectual \\
\hline 63 & & & $\mathrm{O}$ & Algo não explicável & Primitiva \\
\hline 66 & & E M & & $\begin{array}{l}\text { Sempre senti a presença de Deus, que ele sempre me } \\
\text { ajudou nas horas que precisei e acho que meus pais e } \\
\text { minha familia principalmente me ensinaram valores que } \\
\text { acho correto e por isso acho que acreditas em Deus é } \\
\text { certo }\end{array}$ & $\begin{array}{l}\text { Ético- } \\
\text { moral }\end{array}$ \\
\hline
\end{tabular}


QUADRO 9 - Análise das respostas sobre outros significados para as crenças religiosas de acordo com o modelo empírico teórico de J. B. Pratt na questão: Como é Deus para você ? (continuação)

\begin{tabular}{|c|c|c|c|}
\hline Atleta & Outras & Justificativa & Crença \\
\hline 88 & $\mathrm{O}$ & $\begin{array}{l}\text { É uma energia que se acreditarmos nos dará proteção e } \\
\text { sabedoria para escolher os caminhos certos da vida }\end{array}$ & Intelectual \\
\hline 89 & $\mathrm{O}$ & $\begin{array}{l}\text { Sim, porque simplesmente me sinto bem acreditando } \\
\text { nele, conversando com ele }\end{array}$ & Primitiva \\
\hline 91 & $\mathrm{O}$ & $\begin{array}{l}\text { Principalmente pela tradição que minha mãe tem, e } \\
\text { através disso tirei para mim as coisas interessantes dessa } \\
\text { tradição }\end{array}$ & Primitiva \\
\hline 92 & $\mathrm{O}$ & $\begin{array}{l}\text { Porque tudo acontece conforme sua vontade, porque } \\
\text { acredito plenamente que somente ele tem o poder de nos } \\
\text { ajudar, mas é claro que estando em contato com as } \\
\text { sagradas escrituras é que nos deparamos com as } \\
\text { maravilhas que desse Deus }\end{array}$ & Primitiva \\
\hline 94 & $\mathrm{O}$ & & Em branco \\
\hline 95 & $P$ & $\begin{array}{l}\text { Com base na bíblia sagrada, também já sente e sinto a } \\
\text { presença de Deus agir em minha vida. Ele é tudo para } \\
\text { mim }\end{array}$ & Emocional \\
\hline 99 & $\mathrm{O}$ & $\begin{array}{l}\text { Deus para mim é um todo, então acredito nele sem } \\
\text { precisar de prova ou experiência de fato }\end{array}$ & Primitiva \\
\hline 100 & $\mathrm{O}$ & $\begin{array}{l}\text { Não eu nunca senti sua presença e nunca me interessei } \\
\text { por isso }\end{array}$ & Outra \\
\hline 101 & & Não sei mas acredito & Primitiva \\
\hline 110 & $\mathrm{O}$ & $\begin{array}{l}\text { Por costumes da minha família aprendi que ele é meu } \\
\text { protetor }\end{array}$ & Primitiva \\
\hline
\end{tabular}

Legenda: $C=$ Caracterização: $P=$ primitiva $I=$ Intelectual $E=$ emocional $E=$ ético-moral $O=$ outra

Pelos dados constantes do QUADRO 9, nota-se que o número de atletas que opta pela alternativa "outra" aumenta, quando as perspectivas de crença religiosa são os motivos pelos quais o atleta acredita em Deus; a pesar da dificuldade para caracterizar algumas respostas, a análise das justificativas das respostas permite que a maior parte delas seja caracterizadas, segundo os postulados teóricos do instrumento definido em torno dos conceitos empíricos e teóricos das pesquisas sobre crenças religiosas delineadas em torno da obra J. B. Pratt. 
A resposta do atleta 100, não foi caracterizada porque ele formulou uma justificativa para fato de não acreditar em Deus, expondo os conceitos de Deus, nos quais não acredita, "Não, eu nunca senti sua presença e nunca me interessei por isso" evidenciando uma justifica de resposta caracterizada pela crença emocional (nunca senti sua presença) e permeada por aspectos da crença intelectual (nunca me interessei por isso).

As respostas e justificativas formuladas por esse atleta, ao longo de todo o Inventário Pratt de crenças religiosas no esporte, não são suficientes para validá-lo entre a população de atletas ateus, mas é favorável a concepção de que o instrumento pode ser respondido tanto por crentes como não crentes.

Porcentuais descritivos dos domínios das crenças religiosas dos atletas de handebol, com base no motivo pelos quais eles justificam a crença em Deus, são destacados na FIGURA 11.

INTELECTUAL

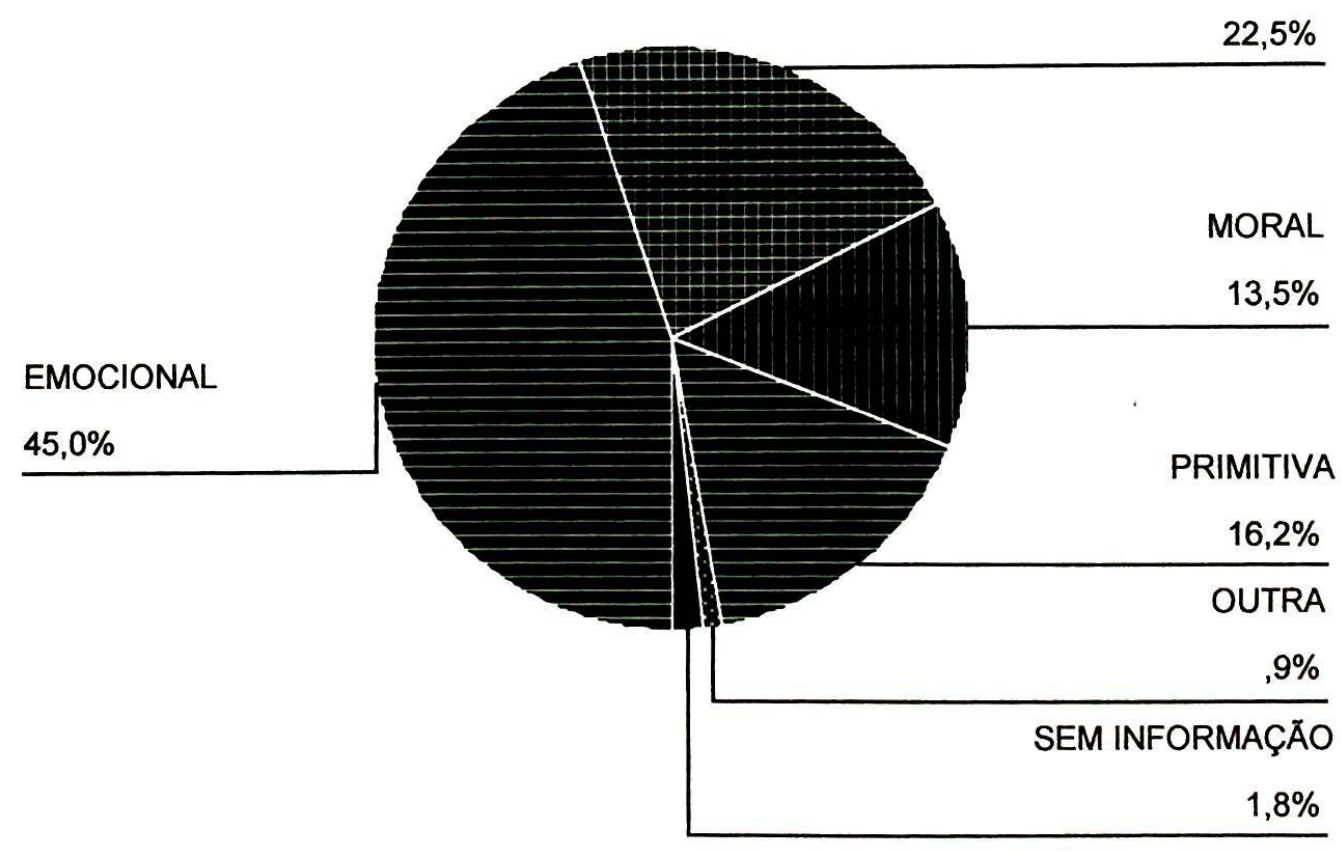

FIGURA 11 - Descrição das crenças dos atletas, sob as perspectiva: Você acredita em Deus? É ... 
Pela FIGURA 11, é possivel visualizar as mesmas tendências reveladas nas questões anteriores, a variabilidade de conceitos de crenças religiosas pautado nos motivos, pelos quais os atletas acreditam em Deus, indicando a predominância da crença emocional $48,6 \%$, a crença intelectual $22,5 \%$, primitiva $16,2 \%$ e ético-moral $13,5 \%$. Estas modalidades de crença religiosa apresentaram-se como as principais tendências entre os atletas; neste ponto, conclui-se com base nos dados das FIGURAS 9, 10 e 11 e nos QUADROS 7, 8 e 9 favoravelmente à hipótese de que as crenças religiosas primitiva, intelectual, emocional e ético-moral podem ser caracterizadas, pela representação que os atletas possuem sobre a figura de Deus.

Nas correlações entre crenças religiosas e lócus de controle, são apresentados os dados obtidos com o Inventário Pratt de crenças religiosas no esporte. Porcentuais à respeito da percepção do atleta sobre Deus, como interferência positiva ou ajuda no esporte são destacados na FIGURA 12.

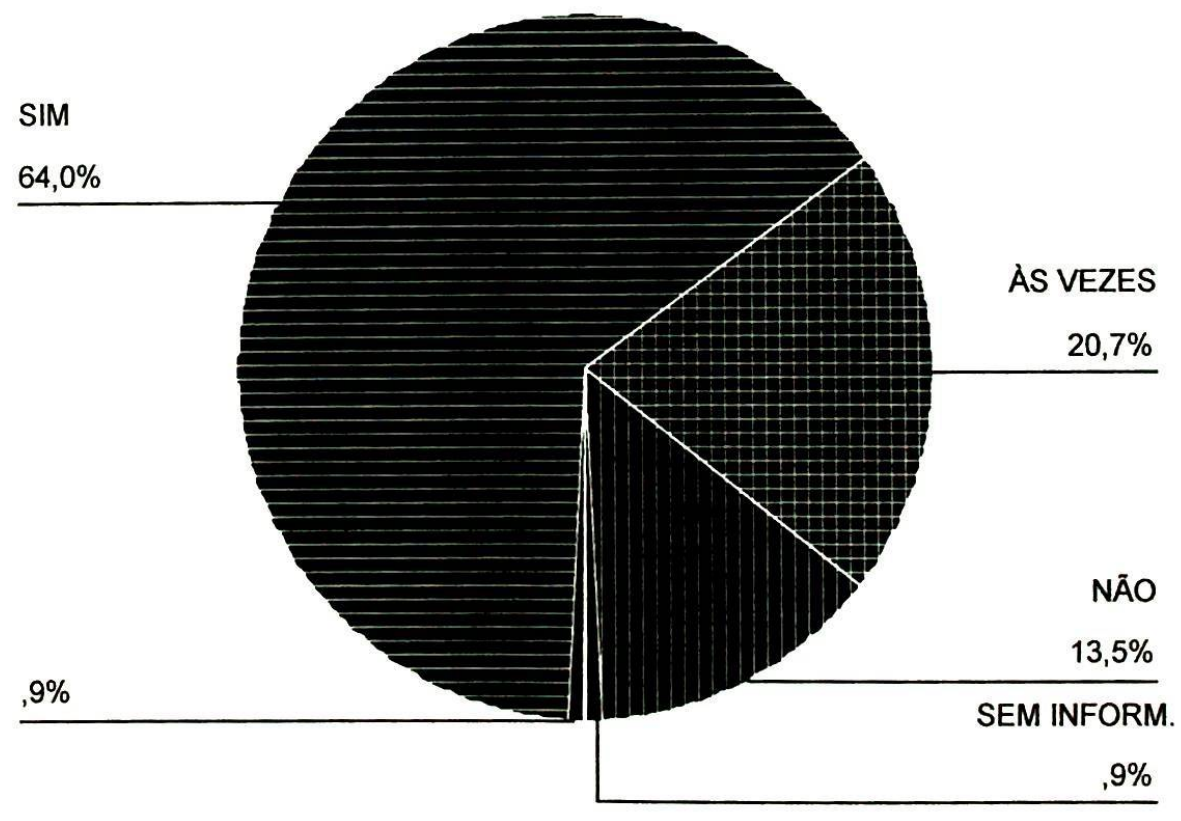

FIGURA 12 - Descrição das crenças dos atletas, sob as perspectiva: Você acredita que Deus poderia ajudar a vencer obstáculos no esporte? 
Os dados da FIGURA 12 evidenciam que a maior parte dos atletas de handebol $(64,0 \%)$ acreditam que Deus pode ajudar a vencer obstáculos no esporte, $20,7 \%$ que Deus pode ajudar às vezes e $13,5 \%$ declararam efetivamente acreditar que Deus não ajuda a superar obstáculos no esporte.

A opinião dos atletas quanto à interferência de Deus nas derrotas é destacada na FIGURA 13.

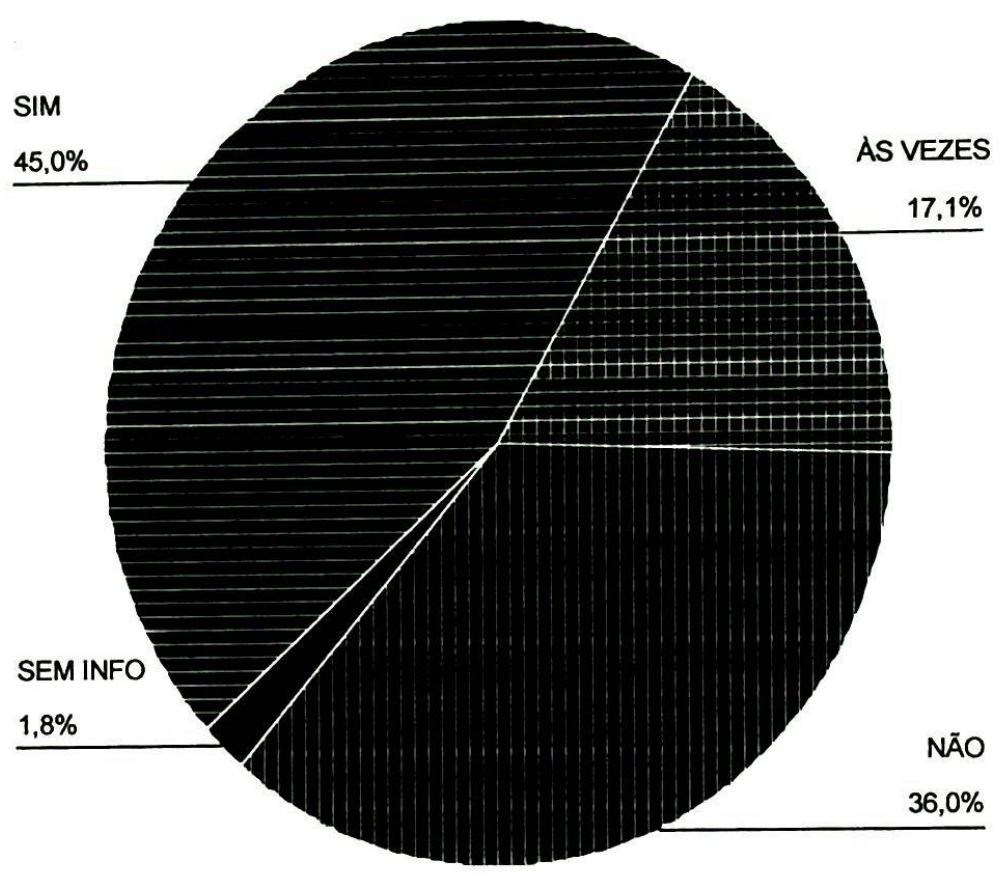

FIGURA 13 - Descricão das crencas dos atletas, sob as perspectiva: E nas derrotas Deus teria alguma participação?

A FIGURA 13 mostra que, sob a perspectiva da derrota, a opinião dos atletas se altera significativamente em relação à percepção de Deus como ajuda no esporte; pois, $45,0 \%$ dos atletas consideraram que Deus não participa nas derrotas, 17,1\% que interfere às vezes, e que o número de atletas que acredita que Deus não participa na derrota triplicou, assim, 36,0\% declaram acreditar que Deus não participa nas derrotas.

A opinião dos atletas quanto à percepção de Deus como um suporte psicológico, é destacada na FIGURA 14. 


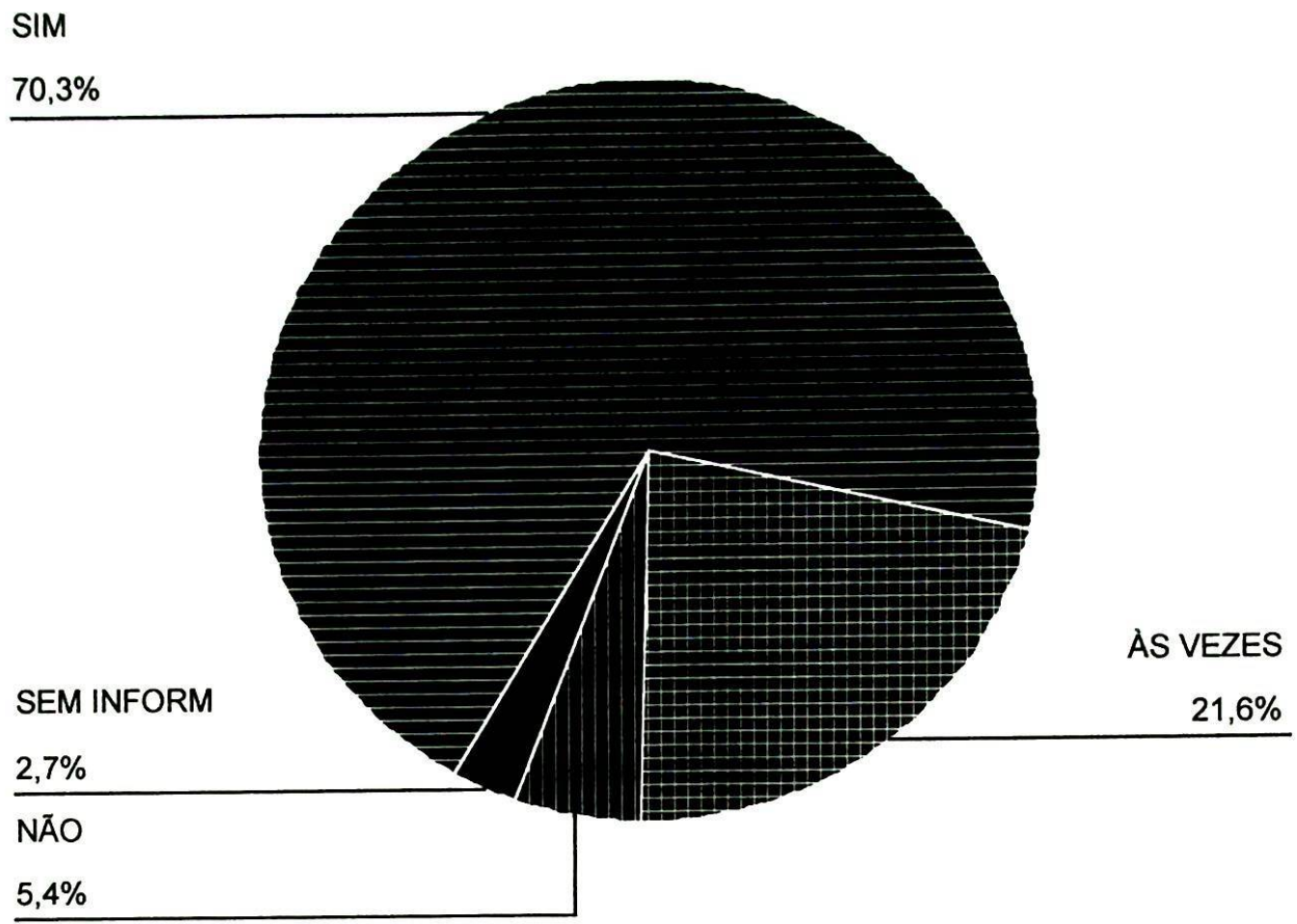

FIGURA 14 - Descrição da opinião dos atletas sobre Deus como suporte psicológico: Deus seria um suporte psicológico para o atleta?

Os dados da FIGURA 14 mostram que a grande maioria $(70,3 \%)$ considera Deus como um suporte psicológico ao atleta, $21,6 \%$ que Deus apresenta-se, às vezes, como suporte psicológico ao atleta; e apenas $5,4 \%$ responderam efetivamente que Deus não seria um suporte psicológico ao atleta.

Considerando o hábito de rezar para obter a vitória, os atletas posicionaramse sobre a questão, conforme os dados da FIGURA 15. 


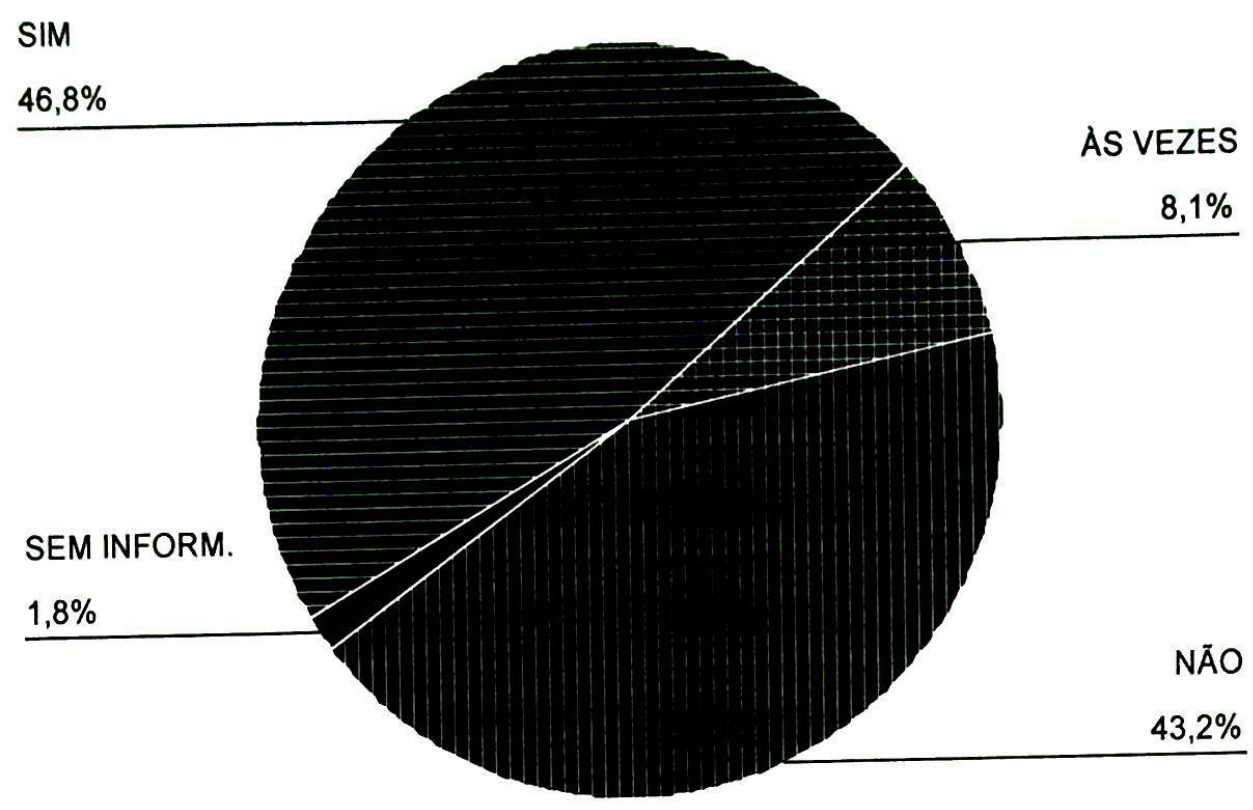

FIGURA 15 - Descrição do comportamento dos atletas sob a perspectiva: Você reza para obter a vitória nas competições esportivas?

A FIGURA 15 demonstra que houve uma divisão relativamente equilibrada entre atletas que declararam rezar $(46,2 \%)$ para obter a vitória nas competições esportivas, $43,2 \%$ de atletas que não rezam e $8,1 \%$ declararam que rezam, às vezes, para obter a vitória.

Entretanto, sob as perspectivas de derrotas e dificuldades o número de atletas que faz orações aumenta, pois os atletas afirmaram que rezam para superar dificuldades no esporte.

Os dados relativos ao habito dos atletas em rezar quando as coisas não dão certo, são destacados na FIGURA 16. 


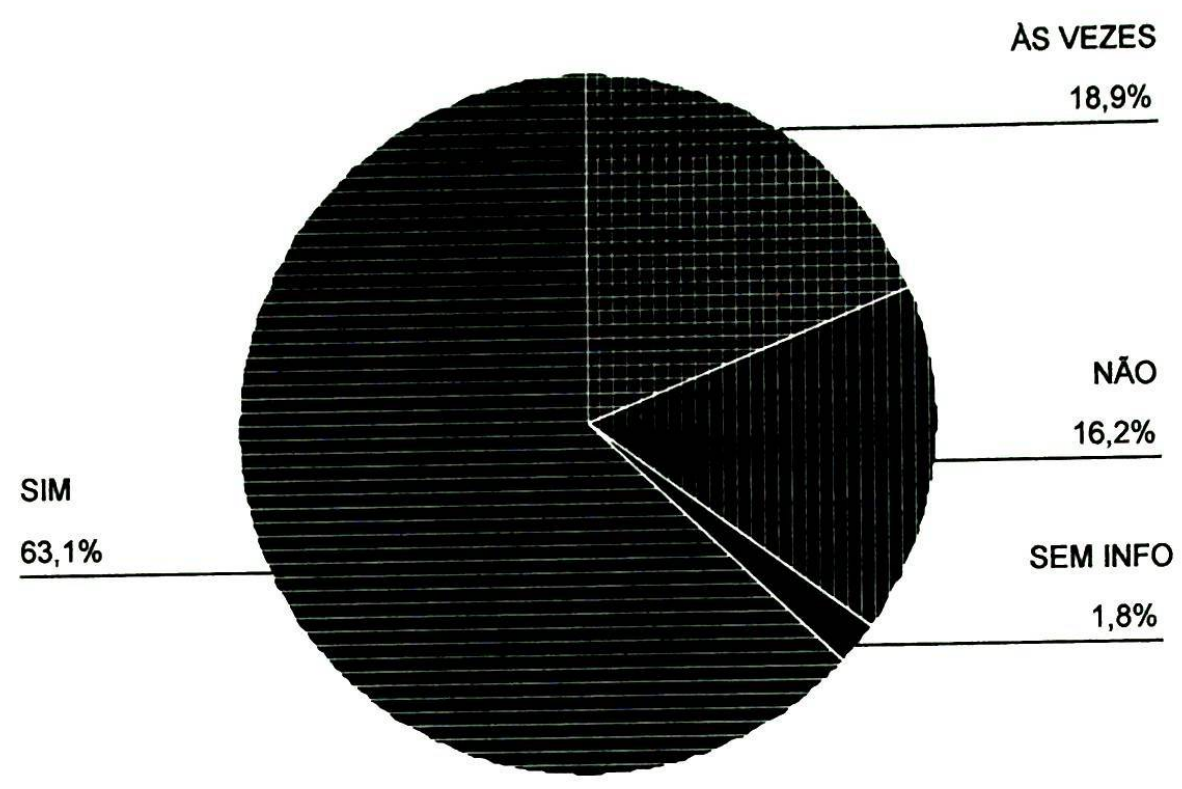

FIGURA 16 - Descrição do comportamento dos atletas sob a perspectiva: E quando as coisas não dão certo você faz orações?

Os dados da FIGURA 16, pode ser compreendidos como evidências sobre a religiosidade dos atletas, como uma forma de enfrentamento, caracterizando uma das inúmeras acepções listadas pelos lexicógrafos HOUAISS (2002), entre as quais, a expressão "ver a Deus pelos pés", cujo significado é ter um grande consolo em momento de aperto ou sair-se bem em uma situação dificil, uma idéia que, também, se estende à religião como forma de enfrentamento em situações bastante adversas, exemplo disso as doenças terminais PAIVA (1998), evidenciando uma grande demanda psicológica no esporte por parte dos atletas no esporte de rendimento.

A seguir, são apresentadas as principais correlações entre o lócus de controle, características sociotécnicas, domínios de crenças religiosas e sentimento de religiosidade dos atletas em relação ao esporte. 


\subsection{Correlações entre lócus de controle e as características sociotécnicas dos Atletas de Handebol de alto nivel de desempenho}

Pelos dados obtidos na aplicação da escala multidimensional do lócus de controle do esporte e do Inventário Pratt de crenças religiosas no esporte, a seguir são apresentados os principais cruzamentos entre as variáveis sociotécnicas, domínios de lócus de controle e crenças religiosas dos atletas de handebol.

A correlação entre sexo e lócus de controle sugere a aceitação da hipótese alternativa $\left(\mathrm{H}_{1}\right)$, pois pelo teste post-hoc de turkey, houve diferença estatisticamente significativa $(p<0,05)$ ao lócus de controle externo sorte-azar maior no sexo feminino (LCI $p=0,5586$; LCE S-A $p=0,0268$ e LCE PP $p=0,5641)$. Cujo espectro de variabilidade ao lócus de controle externo sorte-azar, nas equipes feminina $e$ masculina são destacados na FIGURA 17.

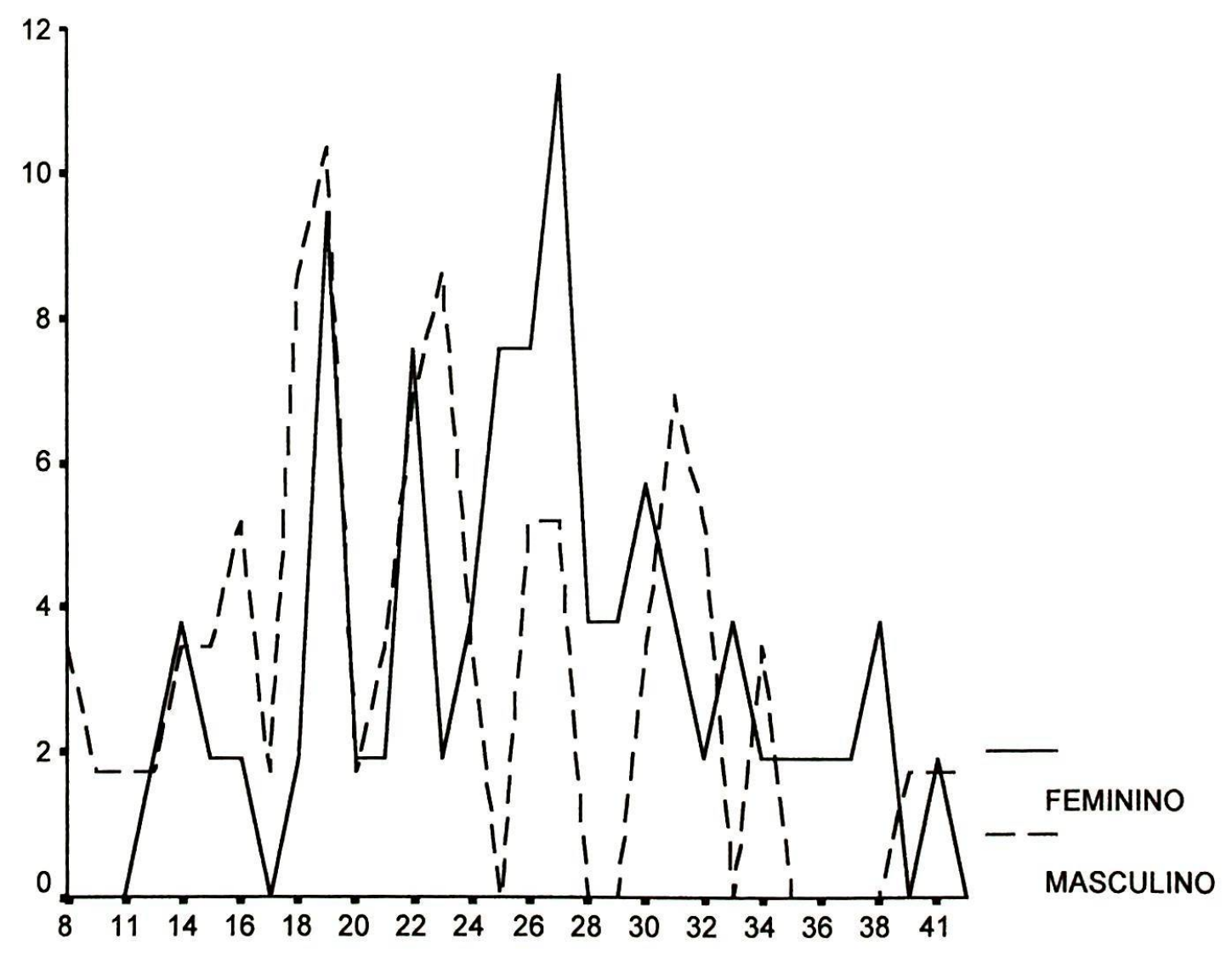

FIGURA 17 - Descrição da variabilidade dos escores de lócus de controle externo sorte-azar nas equipes femininas e masculinas 
Os dados da FIGURA 17 demonstram que a variabilidade do lócus de controle externo sorte-azar nas equipes feminina e masculina, abrangem praticamente toda a faixa da escala de lócus de controle (min. 0 - max. 48), entretanto evidenciam as diferenças que sugerem a aceitação da hipótese alternativa $H_{1}$. relativa a diferenças de lócus de controle em relação às variáveis sociotécnicas; valor médio de LCE SA 26 (equipe feminina) e LCE SA 22 (equipe masculina).

Este resultado pode estar associado a diversos aspectos, entre os quais, a influência dos fatores cultural, social e psicológico, à inserção da mulher no meio esportivo.

A correlação entre lócus de controle e idade dos atletas também sugere a aceitação da hipótese alternativa $(\mathrm{H} 1)$, pois pelo teste post-hoc de turkey houve diferença estatisticamente significativa $(p<0,05)$ para lócus de controle externo sorteazar maior para atletas mais jovens $(\mathrm{LCl} p=0,2098$; LCE $S-A \quad p=0,0040$ e LCE PP $p=0,0869$ ).

A FIGURA 18, construída com base na representação gráfica das médias sobre a análise de variância simples (one-way Anova) destaca a correlação entre o lócus de controle externo sorte-azar e as faixas etárias dos atletas de handebol pesquisados. 


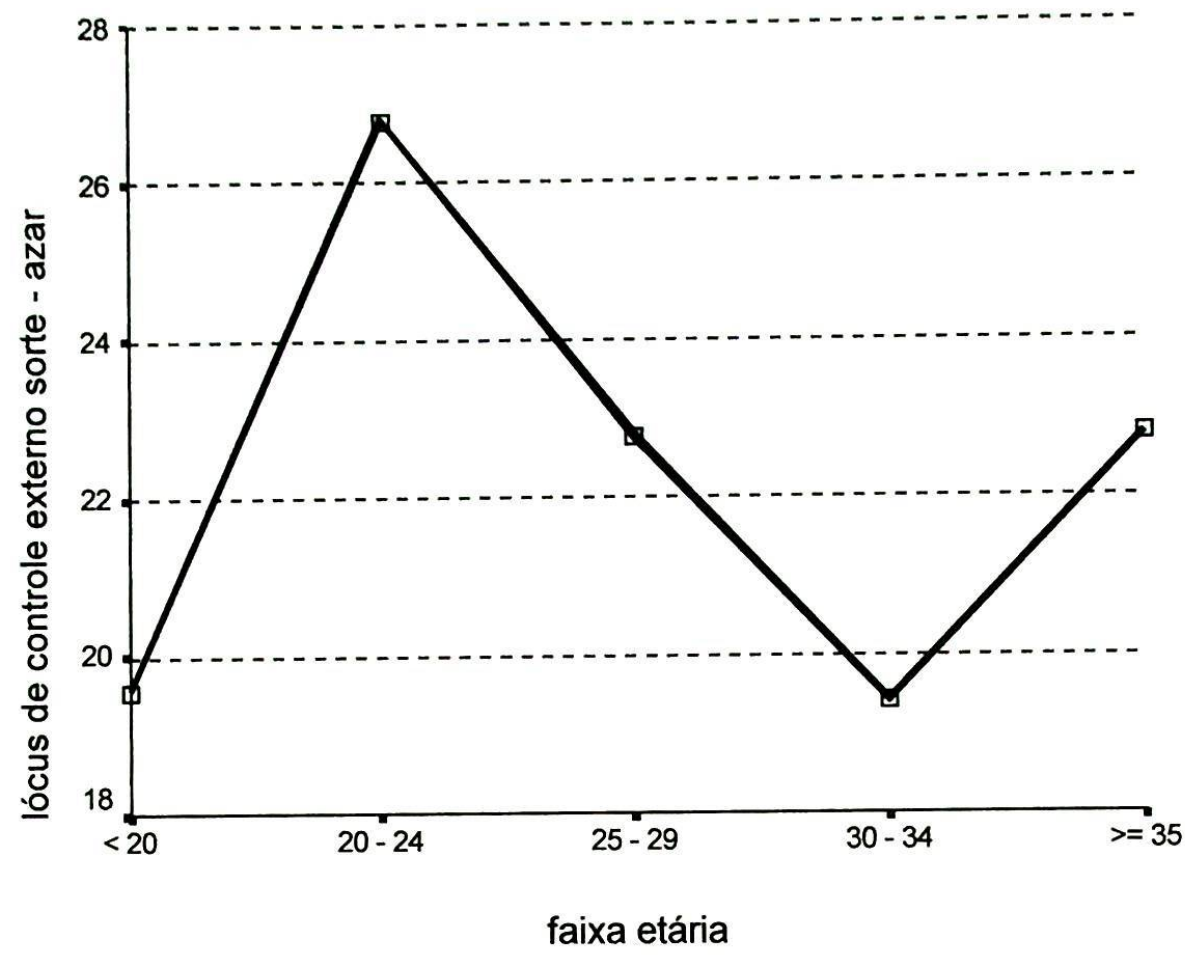

FIGURA 18 - Correlação entre escores de lócus de controle externo sorte-azar e as faixas etárias de atletas de handebol

Na FIGURA 18, os dados evidenciam que há diferenças de lócus de controle externo sorte-azar entre as faixas etárias dos atletas, maior para aqueles com idade entre 20 e 24, valor médio LCE SA 26, e menor para os atletas com idade entre 30 e 34 anos, valor médio LCE SA 21,91.

Os resultados sugerem a aceitação da hipótese alternativa $\left(\mathrm{H}_{1}\right)$, o que pode ser compreendido, segundo a natureza cognitiva do conceito lócus de controle, uma provável explicação para a predominância de atletas com mais de 25 anos nas seleções brasileiras de handebol, evidenciando que a experiência, assim como as aprendizagens podem contribuir para diminuir as expectativas de controle por eventos de "natureza incontrolável", por isso relegados ao lócus externo sorte- azar.

As evidencias sobre as interferências dos aspectos psicológicos no esporte, implicam em mudanças na preparação dos atletas, um fator que poderia fazer diferença, conferindo ao treinamento psicológico, um certo valor, até então subestimado, ou pouco utilizado no Brasil. 
Dando seqüência à apresentação dos principais resultados obtidos sobre o cruzamento do lócus de controle e as características de natureza sociotécnicas dos atletas de handebol. A correlação entre o lócus de controle e as posições assumidas pelos atletas nas equipes, também sugere a aceitação da Hipótese alternativa $\left(\mathrm{H}_{1}\right)$, o teste post-hoc de turkey revelou diferença estatisticamente significativa $(p<0,05)$ entre as posições ocupadas pelos atletas nas equipes e o lócus de controle interno ( $L C I p=0,0425$; LCE S-A $p=0,1866$ e LCE PP $p=0,2800$ ), maior para atletas polivalentes e menor para os pivôs.

Os níveis de variação do lócus de controle interno e a posição assumidas pelos atletas nas equipes são destacados na FIGURA 19, construída estruturalmente com base na representação gráfica das médias pela análise de variância simples one-way anova.

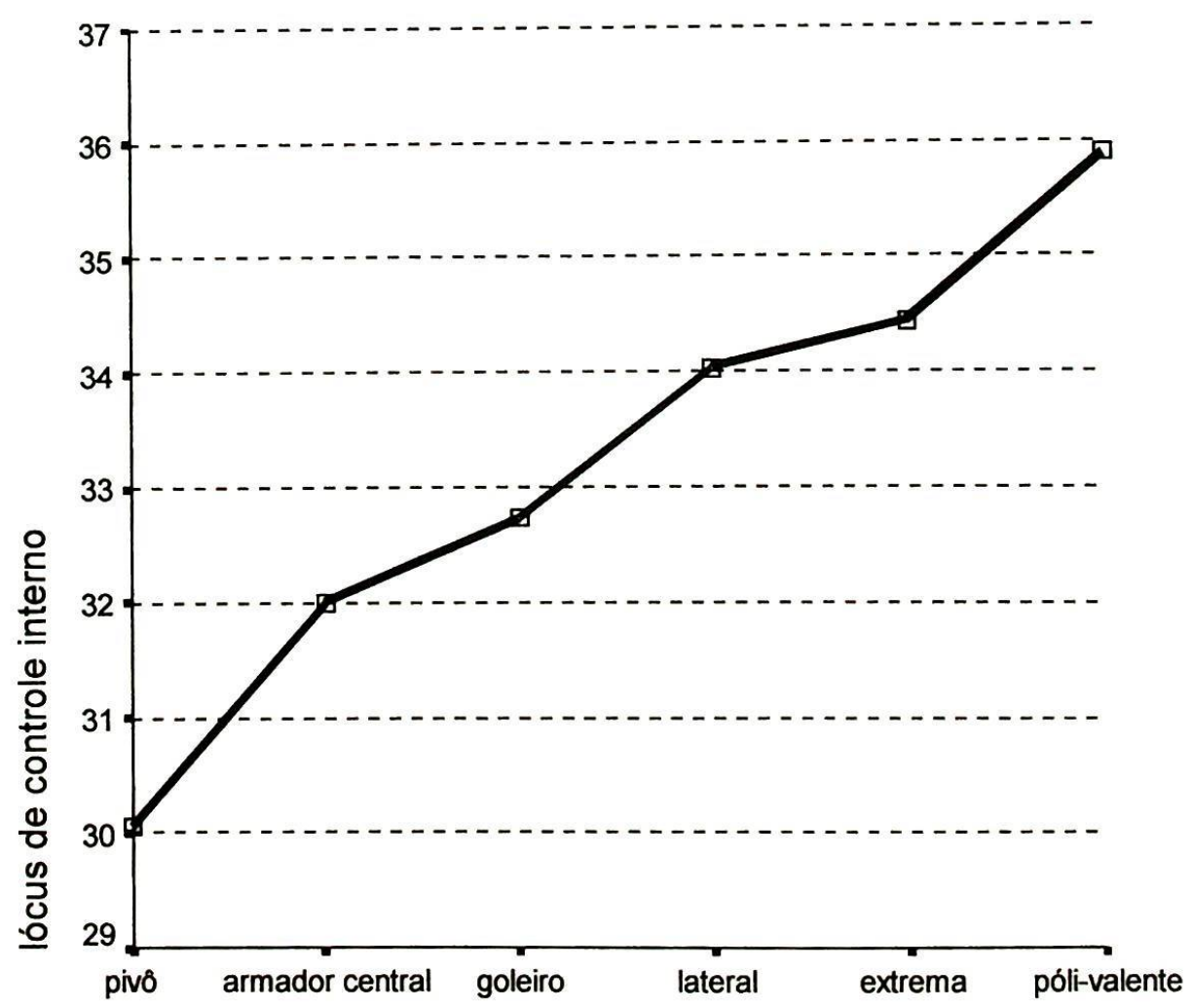

FIGURA 19 - Correlação entre escores de lócus de controle interno e posições assumidas pelos atletas nas equipes 
A FIGURA 19 demonstra as diferenças de lócus de controle entre as posições assumidas pelos atletas nas equipes, evidenciando diferença estatisticamente significativa para escores mais elevados de lócus de controle interno $(35,89)$ para os atletas polivalentes (ocupam mais de uma posição na equipe) e menores escores de lócus de controle interno para os pivôs $(30,00)$

Evidenciando a possivel influência de aspectos psicológicos ao lócus de controle, pois os atletas polivalentes, ao assumirem mais de um posto nas equipes, chamam para si maiores responsabilidades, possibilidades de sucesso e de insucesso para suas equipes, o que resultou em maiores escores de lócus de controle interno.

Por outro lado, os pivôs obtiveram os menores escores de lócus de controle interno. Todos os atletas deveriam ser igualmente responsáveis pelo sucesso ou insucesso de suas equipes. Porém, o que se pode verificar no caso dos pivôs, é que apesar da tendência que se constata no handebol, para atletas cada vez mais altos e fortes, nas equipes femininas e masculinas. Os pivôs se diferenciam desta tipologia, comumente são os atletas mais baixos, pois têm como características a agilidade, no ataque buscam penetrar na defesa e criar condições para que seus companheiros, com chute mais potente, arremessem a gol, o que demanda para o atleta um grande repertório de passes, mas, também, eles fazem arremessos a gol, em chutes que surpreendem o goleiro com habilidade. No entanto, apresentaram menores escores de lócus de controle interno, sugerindo que o lócus de controle poderia ser considerado na preparação psicológica dos atletas, dado que se relacionou aos aspectos orgânicos e psicológicos envolvidos nas equipes.

Em contraposição a tendência verificada no teste piloto para escores mais elevados de lócus de controle externo sorte-azar, maior para atletas com nivel superior. Não houve correlação estatisticamente significativa entre niveis de escolaridade e dominios de lócus de controle, sugerindo, a rejeição da hipótese alternativa ( $L C I p=0,4612$; LCE S-A $p=0,8816$ e LCE PP $p=0,2617$ ).

Os resultados encontrados até esse ponto, são favoráveis à hipótese central de que existe um referencial psicossociológico de tomadas de decisão por parte dos atletas definivel em torno do lócus de controle interno, externo sorte-azar e externo pessoas poderosa. 


\subsection{Correlações entre lócus de controle e crenças religiosas de Atletas de Handebol de alto nivel de desempenho}

Não houve correlações estatisticamente significativas $(p<0,05)$ entre os domínios de lócus de controle interno, externo sorte-azar e externo pessoas poderosas pelas modalidades de crenças religiosas primitiva, intelectual, emocional e ético-moral, estruturadas em torno da representação de Deus nas três primeiras questões do Inventário Pratt de crenças religiosas do esporte indicando a aceitação da hipótese de nulidade (Ho): $1-O$ que a religião significa pessoalmente para você? E... (LCI $p=0,1134$; LCE S-A $p=0,2974$ e LCE PP $p=0,1472) ; 2$ - Como é Deus para você? ( $L C I ~ p=7774$; LCE S-A $p=0,2848$ e LCE PP $p=0,2165)$; 3- Você acredita em Deus? É... (LCI $p=0,4884$; LCE S-A $p=0,7791$ e LCE PP $p=0,3669)$.

A ausência de correlação estatística, entre o lócus de controle e as modalidades de crenças religiosas, nestas questões, poderia ser compreendida como resultante de um imbricamento entre as modalidades de crenças religiosas, resultante de um inter-relacionamento entre as variáveis, predominando determinados aspectos de acordo com o contexto.

Embora, os fenômenos em análise, sejam de grande complexidade, a associação entre as modalidades de crenças religiosas e lócus de controle revelouse relativamente estável nas três questões, em que a crença intelectual aparece associada com menores escores de lócus de controle interno e as crenças primitiva e ético-moral aos escores mais elevados, fato que confere aos instrumentos perspectivas favoráveis, compativeis com as análises que se seguem as outras questões que completam o instrumento.

Os escores médios de lócus de controle pelas categorias de crenças religiosas obtidos na questão dois, a respeito da representação de Deus para o atleta, são destacados na TABELA 9. 
TABELA 9 - Valores médios de Lócus de controle pelas categorias de crenças religiosas obtidos na questão formulada com base na representação de Deus para o atleta

\begin{tabular}{llrrr}
\hline \hline & & LCl & LCE SA & LCE PP \\
\hline Ateu & Média & 29,00 & 18,00 & 26,00 \\
& $\mathrm{~N}$ & 1 & 1 & 1 \\
\hline Crença intelectual & Média & 32,59 & 26,12 & 25,09 \\
& $\mathrm{~N}$ & 34 & 34 & 34 \\
\hline Crença emocional & Média & 33,24 & 23,29 & 24,24 \\
& $\mathrm{~N}$ & 45 & 45 & 45 \\
\hline Crença moral & Média & 34,19 & 25,33 & 24,48 \\
& $\mathrm{~N}$ & 21 & 21 & 21 \\
\hline Crença primitiva & Média & 34,78 & 21,00 & 18,78 \\
& $\mathrm{~N}$ & 9 & 9 & 9 \\
\hline Sem informação & Média & 35,00 & 19,00 & 23,00 \\
& $\mathrm{~N}$ & 1 & 1 & 1 \\
\hline Total & Média & 33,32 & 24,27 & 24,11 \\
& $\mathrm{~N}$ & 111 & 111 & 111 \\
\hline \hline
\end{tabular}

LCI: $p=0,774 ;$ LCE S-A: $p=0,2848 ;$ LCE PP: $p=0,2165$

A tendência para menores escores de lócus de controle interno verificada no ateísmo, foi compensada por escores mais elevados de lócus de controle externo pessoas poderosas, observando-se $\circ$ fato de que esse atleta, apresentou o maior escore de lócus de controle externo pessoas poderosas, como se pode ser constatado nos dados da TABELA 9 e baixo índice de internalidade IT=7, cujo valor médio foi 9,13 (conforme cálculo demonstrado no item 9.2).

Seguindo a mesma tendência verificada em relação ao ateismo, atletas que associaram seus sentimentos de religiosidade a crença intelectual, também, aparecem associados à menores escores de lócus de controle interno ( $\mathrm{LCl} 32,59$ ), fatos que evidenciam o conflito e a dúvida, característicos da crença intelectual e ateísmo, enfraquecendo a força do self, implicando em menores escores de lócus de controle interno. Porém, no caso da crença intelectual, verifica-se que em contraposição à menor internalidade, o predomínio do lócus de controle externo 
sorte-azar (LCE SA 26,12) surgiu como o maior escore verificado nos dados da TABELA 9, e o indice de internalidade $(I T=6,98)$ um valor ainda menor que o verificado no caso do ateísmo.

Por outro lado, à crença primitiva caracterizada pela aceitação inconsciente do objeto religioso, manifestar-se-ia como um sentimento natural, sem crises e questionamentos, apresentou-se associada aos maiores escores de lócus de

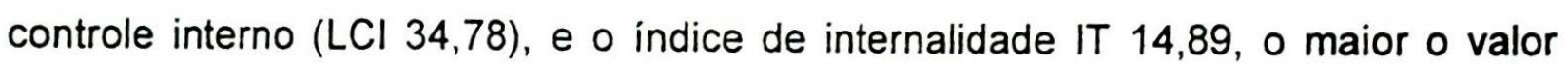
verificado, $212,71 \%$ maior do que no ateísmo e $213,32 \%$ maior que na crença intelectual.

Estes resultados, evidenciam aquilo que poderia ser caracterizado como castigo de Prometeu, entre os diversos significados possiveis ao mito, simbolizando o conflito resultante da intelectualidade, característica da pós-modernidade, uma ave que devora todas as manhãs o coração (ou figado em algumas versões do mito) de Prometeu, que entretanto, regenera-se durante a noite (o mergulho no inconsciente), para ser novamente devorado pela manhã (a consciência), castigo por ter roubado o fogo aos Deuses, analogia a luz como símbolo do conhecimento dos mistérios, conforme apresentado na FIGURA 5.

Oscilando entre crença primitiva e ético-moral, apresentam-se associadas aos escores mais elevados de lócus de controle interno nas três primeiras questões, reforçando a concepção de que a ausência do conflito traduz-se em maiores escores de lócus de controle interno. Na crença primitiva, pela aceitação inconteste e na crença ético-moral por uma visão mais positiva do esporte, associado à valores éticos e um papel social importante.

Em prosseguimento a apresentação dos resultados obtidos pela correlação entre lócus de controle e sentimentos de religiosidade, na questão: 4- Deus é algo real para, tão real como um amigo terreno, embora diferente? Verificou-se diferença estatisticamente significativa $(p=0,0110)$ ao lócus de controle externo sorte azar, maior para os atletas que, às vezes, consideram Deus como um amigo (LCE S-A: $\operatorname{sim} 25,59$; às vezes - 26,21; não - 21,62). Nesta mesma questão, houve diferença estatisticamente significativa $(p=0,0246$ ) ao lócus de controle interno, maior para os atletas que consideram Deus real como um amigo terreno (sim), os escores médios de lócus de controle interno são destacados na FIGURA 20. 


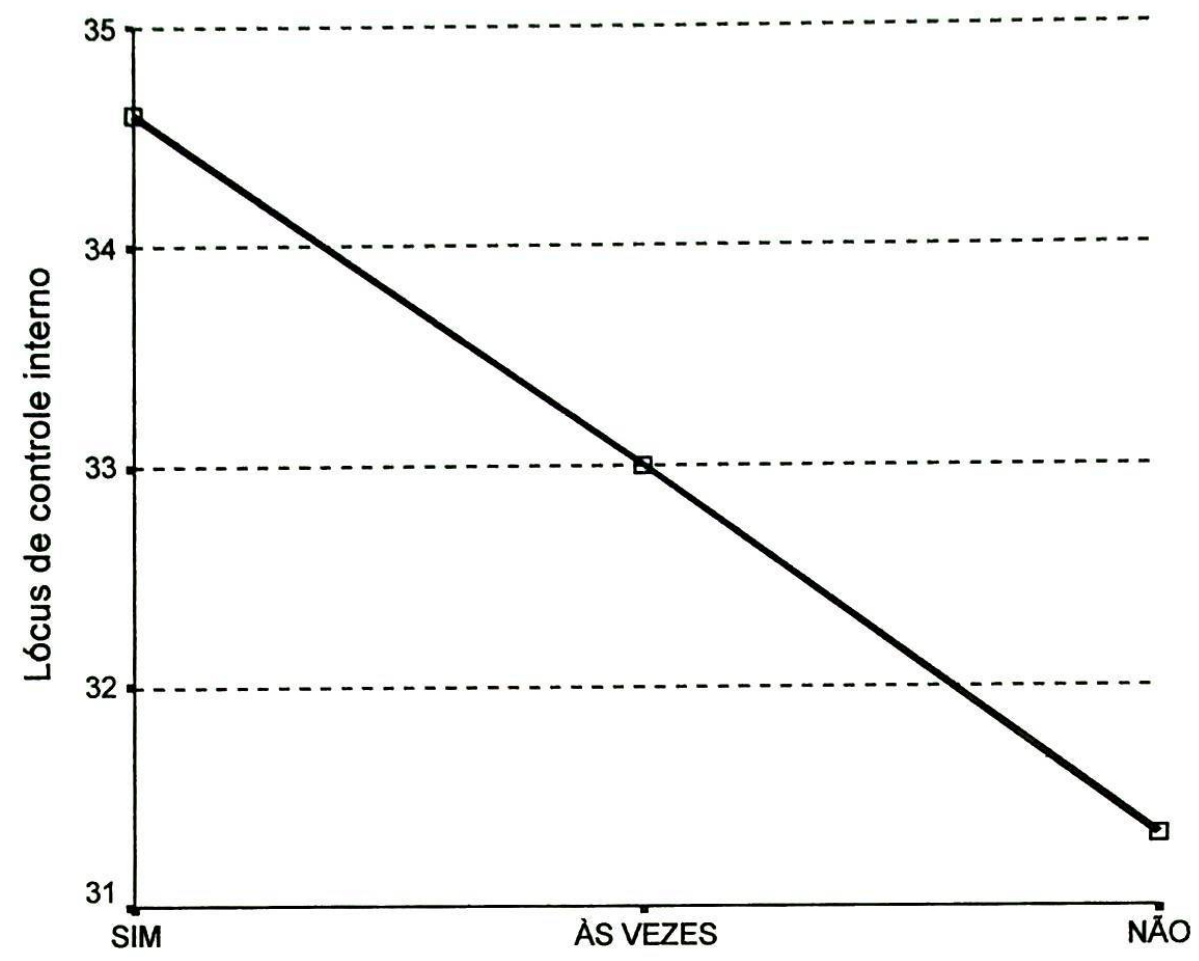

FIGURA 20 - Correlação entre escores de lócus de controle interno e a percepção de Deus na questão: Deus é algo real para você, tão real como um amigo terreno, embora diferente?

Os dados da FIGURA 20 demonstram que atletas que consideram Deus real como amigo, apresentam escores de lócus de controle interno $(34,6)$ significativamente superiores aos que não consideram Deus como um amigo $(31,32)$. Evidenciando aspectos relativos à crença primitiva, associados a maiores escores de lócus de controle interno, e ao mesmo tempo, maior tendência ao lócus de controle externo sorte-azar, maximizado entre os atletas que revelam posição dual, considerando que, às vezes Deus é como um amigo, ressaltando que a dúvida associou-se à maiores escores de lócus de controle externo sorte-azar.

Confirmando esta tendência, na questão seis, atletas que consideraram Deus como ajuda para superar obstáculos no esporte (sim e às vezes), apresentaram pelo teste de post-hoc de Tukey, escores de lócus de controle externo sorte-azar estatisticamente superiores aos atletas que não consideram Deus como uma ajuda para superar obstáculos ( $L C l p=0,9087$; LCE S-A; $p=0,0053$ e LCE PP $p=0,2342$ ), cujos escores médios são apresentados nos dados da FIGURA 21. 


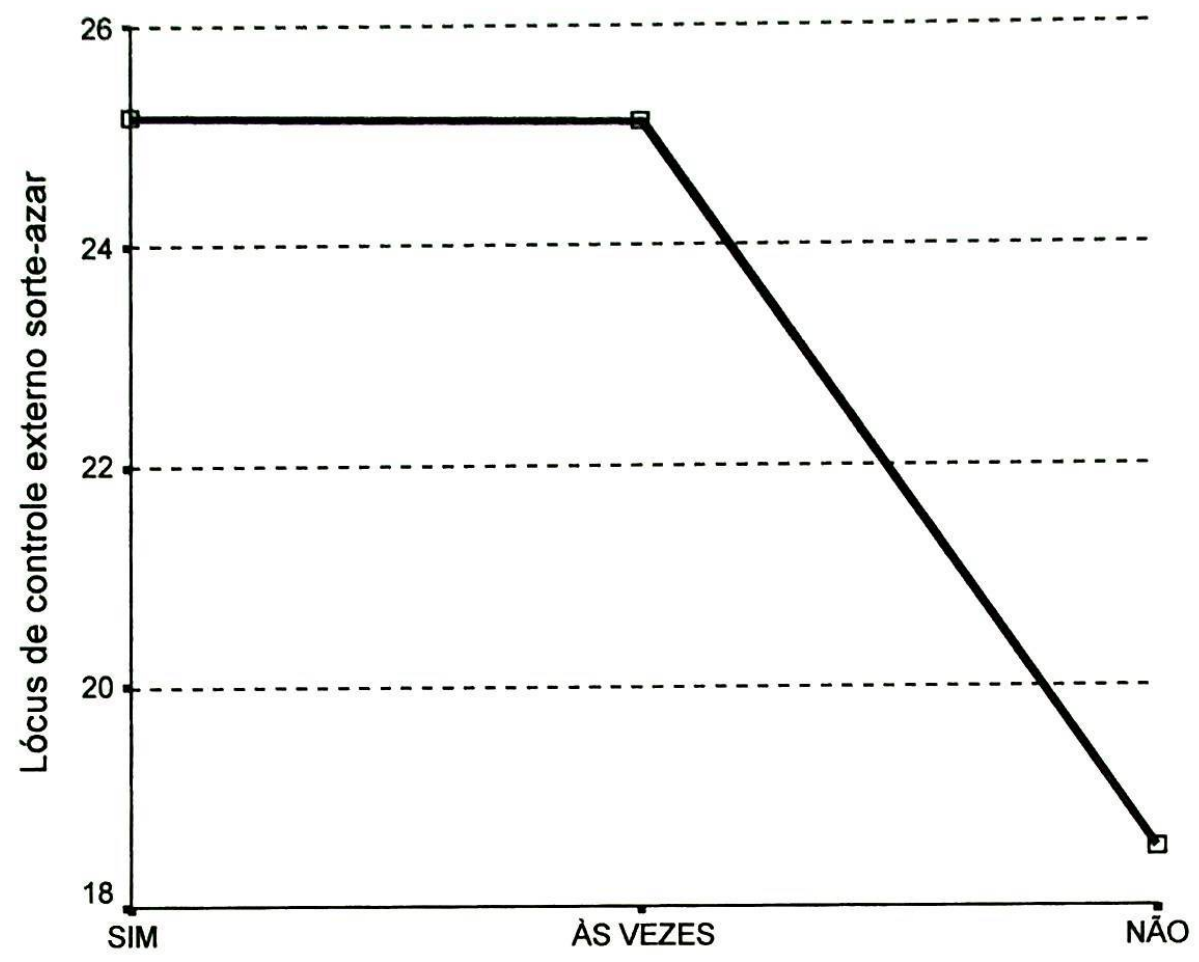

FIGURA 21 - Correlação entre escores de lócus de controle externo sorte-azar e a percepção de Deus na questão: Você acredita que Deus poderia ajudar a vencer obstáculos no esporte?

Os valores destacados na FIGURA 22 demonstram que os atletas de handebol que consideram Deus como ajuda para vencer obstáculos no esporte (LCE SA 25,18 ), e os que admitiram que, às vezes (LCE SA 25,17), mostram escores estatisticamente mais elevados de lócus de controle externo sorte-azar, do que os atletas que não consideram Deus como ajuda para superar obstáculos no esporte (LCE SA 18,53), evidenciando uma idéia que se expressa no senso comum e pelas religiões, sobre os perigos em se considerar Deus como meio para prover bens e conquistas pessoais, conforme enfatizou AUGRAS (2002).

A associação entre lócus de controle externo sorte-azar à percepção de Deus como ajuda para vencer obstáculos no esporte, evidencia uma estrutura psíquica desfavorável ao atleta, o que pode não ter muita eficiência para o desempenho esportivo, dado que expressa um mecanismo defensivo que desmobiliza, o ego e seu núcleo central, o self, pois ao colocar fora do consciente a possibilidade efetiva 
de atingir por si-mesmo, às metas de uma carreira esportiva realista, o atleta inconscientemente, se desmobiliza, comportamento análogo ao adotado em estratégias de coping ao enfrentamento de doenças graves conforme evidenciaram PAIVA (1998) e PORTNOI (2000).

Quanto à questão referente à participação de Deus nas derrotas, não houve diferenças de escores estatisticamente significativas ( $L C l p=0,4633$; LCE S-A $p=$ 0,1030 e LCE PP $p=0,3491$ ). Porém, observou-se que, o número de atletas que acreditam que Deus, pode interferir no esporte, frente a perspectiva da derrota diminui, conforme destacado anteriormente nas FIGURAS 15 e 16, expressando posturas incoerentes quanto à percepção da intervenção divina no esporte.

$\mathrm{Na}$ questão relativa à Deus, como suporte psicológico, observou-se pelo teste de post-hoc de turkey $(\mathrm{LCl} p=0,9612$; $\operatorname{LCE}$ S-A $p=0,4918$; LCE PP $p=$ 0,0163), escores de lócus de controle externo pessoas poderosas significativamente maiores aos atletas que não consideraram Deus como suporte psicológico e menor aos atletas que consideram Deus como suporte psicológico, conforme destacado na FIGURA 22.

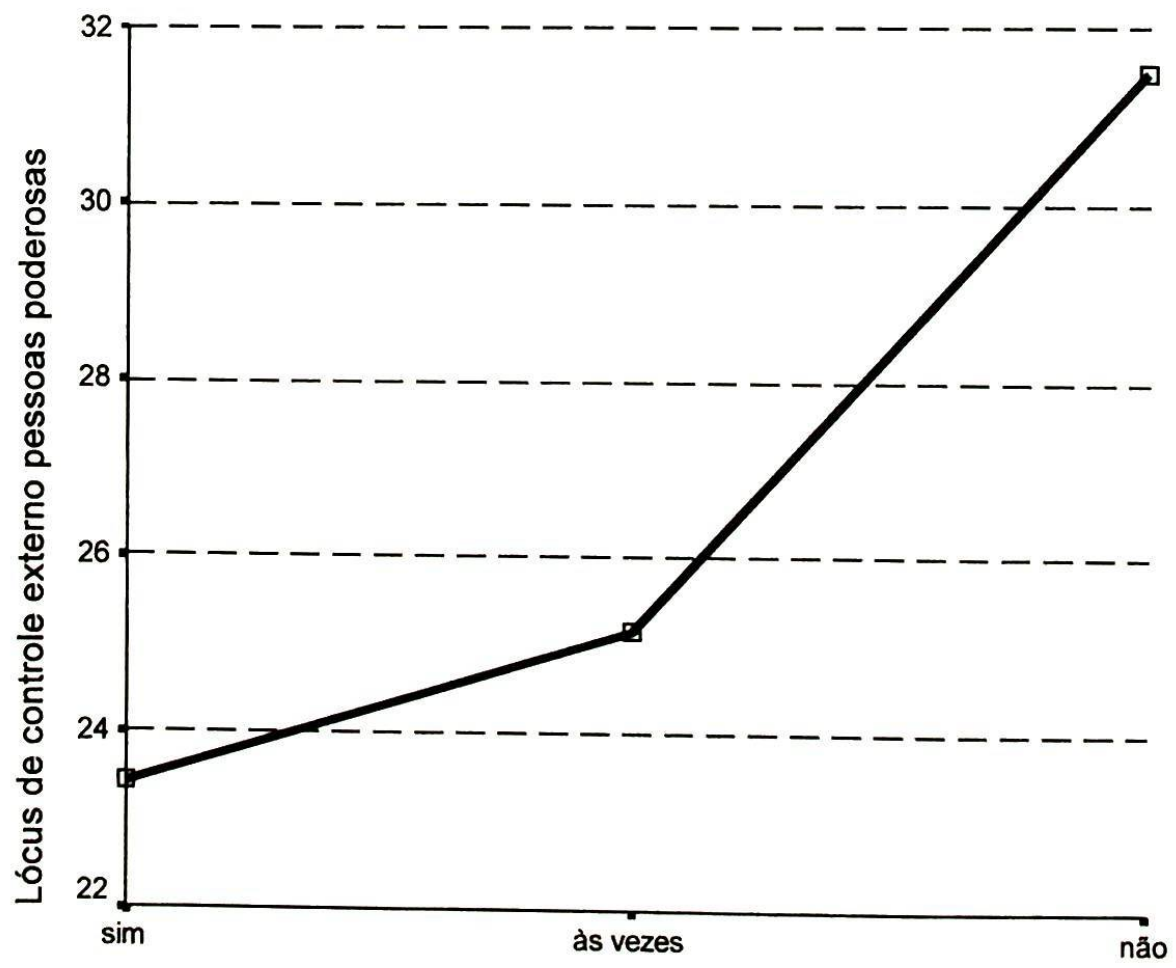

FIGURA 22 - Correlação entre escores de lócus de controle externo pessoas poderosas e a percepção de Deus como suporte psicológico. 
Os escores médios de lócus de controle apresentados na FIGURA 22 evidenciam que os atletas que percebem Deus como suporte psicológico, apresentam escores significativamente menores de lócus de controle externo pessoas poderosas (sim: 23,42). A observação das justificativas dos atletas para a percepção de Deus como suporte psicológico, revelam Deus como proteção aos treinos e jogos, fonte de motivação, pensamentos positivos, força para transpor obstáculos, segurança para superar medo de acidentes, tranqüilidade, paciência, paz interior, conforto, concentração, iluminação para boas jogadas e a confiança de que tudo pode-se com $\circ$ poder da mente. Justificativas que manifestam alguns traços do sentimento de onipotência associado com a crença emocional.

Já, os atletas que não percebem Deus associado a suporte psicológico $(5,1 \%)$ apresentaram escores de lócus de controle pessoas poderosas significativamente maiores (não: 31,50) e justificaram-se afirmando que não dependem Dele; que Deus não se manifesta em jogos; que cada um tem o seu Deus; que a psicologia não está relacionada com Deus; que Deus não é apenas psicológico, mas, também corporal; e um atleta que não justificou sua resposta.

Os dados evidenciam a complexidade do objeto religioso, a não percepção de Deus como suporte psicológico implica em maiores escores de lócus de controle externo pessoas poderosas, tendência análoga aquela observada no ateísmo, a não crença em Deus transparecendo indícios dos conflitos e dúvidas que permeiam a crença intelectual, mesclados a questões que poderiam ser inseridas na esfera ético-moral.

Quanto ao habito dos atletas em rezar para obter a vitória nas competiçōes quando as coisas não dão certo, não revelou diferenças de escores estatisticamente significativas ( $L C I p=0,0579$; LCE S-A $p=0,3156$; LCE PP $p=0,7267$ ). Porém, quando se observa à intenção manifesta pelos atletas na oração, verificou-se pelo teste de teste post-hoc de turkey ( $L C l p=0,0102$; LCE S-A $p=0,2011$; LCE PP $p=$ 0,8507 ) diferença de escores estatisticamente significativa favorável ao lócus de controle interno entre os atletas que afirmam fazer oraçōes para obter equilibrio quando as coisas não dão certo e os atletas que alegam ter outra intenção, conforme os dados apresentados na FIGURA 23. 


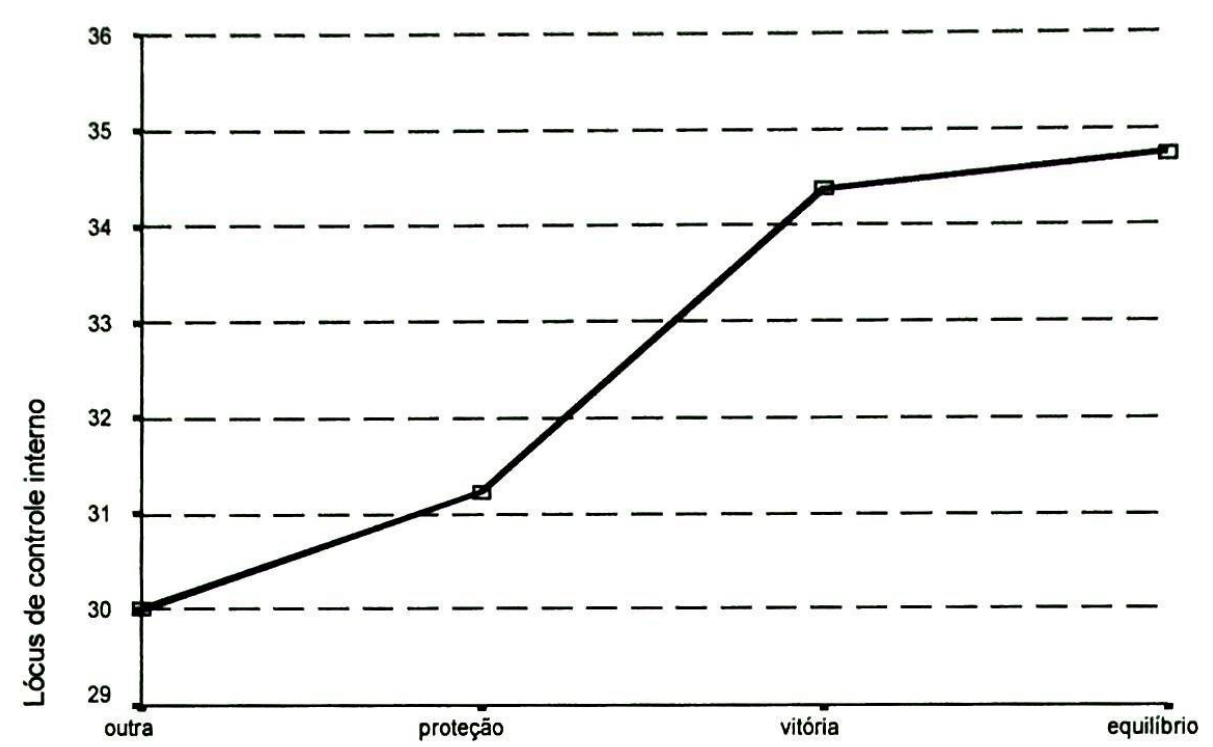

FIGURA 23 - Correlação entre escores médios de lócus de controle interno e a intenção da oração sob as perspectiva de situações difíceis

Os dados apresentados na FIGURA 23 evidenciam que mediante situações de dificuldades no esporte atletas que fazem orações buscando atingir o equilibrio interno ( $\mathrm{LCl} 34,75)$ e a vitória ( $\mathrm{LCl} 34,38)$, apresentaram maiores escores de lócus de controle interno do que os atletas invocam ajuda, proteção (LCI 31,22 - 24,3\%) e

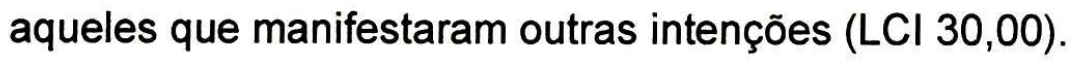

As respostas caracterizadas em "outras" intenções revelam: um atleta que não faz orações, mas procura conversar consigo mesmo, na tentativa de resolver o problema, o mais rápido possível, sem fugir do conflito; um atleta que não acha justo rezar só nos momentos de precisão, pois acredita que deveria tê-lo feito antes; um atleta que pela oração pede orientação e a indicação de um melhor caminho; um atleta que faz orações com o intuito de descobrir onde errou, como poderia corrigir o erro e que aprendizado poderia tirar de seu erro; um atleta que afirmou que faz orações pedindo um bom jogo e proteção, porém quando as coisas não dão certo, se contradiz, afirmando que não faz orações, nem mesmo quando as coisas dão certas e dois sem justificativas.

A percepções dos atletas sobre a oração em situações difíceis, evidencia que a busca de proteção, conflitos e inseguranças associam-se a menores escores de lócus de controle interno. 


\section{PERSPECTIVAS CONCLUSIVAS}

Face aos objetivos, hipóteses e resultados obtidos nesta pesquisa, poderse-ia concluir que:

- A escala multidimensional de lócus de controle do esporte revela um referencial psicossociológico que embasa as expectativas dos atletas sobre o domínio dos eventos e atribuição causal da variabilidade no esporte, definivel pelo lócus de controle interno e o lócus de controle externo sorte-azar e ou pessoas poderosas.

- A escala multidimensional de lócus de controle do esporte constitui-se como um instrumento altamente eficiente, pois aborda de forma simples e objetiva uma temática psicológica complexa.

- A escala multidimensional de lócus de controle do esporte possui eficácia similar a outras escalas multidimensionais de lócus de controle desenvolvidas em áreas específicas, já consagradas pela comunidade cientifica nacional e internacional.

- O referencial psicossociológico de tomada de decisão envolvido pelos atletas de handebol, de ambos os sexos, pelo lócus de controle interno, externo sorte-azar e pessoas poderosas associados aos sentimentos de religiosidade, definidos pelas crenças religiosas primitivas, intelectual, emocional e ético-moral colaboram para delimitar perfis psicológicos de comportamento dos atletas de alto nível técnico de desempenho.

O inventário Pratt de crenças religiosas no esporte caracteriza a espiritualidade e os sentimentos de religiosidade dos atletas como questões indissociáveis do comportamento, designadas por estruturas arquetípicas e processos psicológicos sinalizados pela representação de Deus e a percepção de Sua interferência no meio esportivo, definivel em crenças religiosas primitiva, intelectual, emocional e ético-moral.

- O Inventário Pratt de crenças religiosas no esporte constitui-se como um protocolo de pesquisas metodologicamente eficiente, pois aborda de forma prática um fenômeno que envolve complexidade. 
- O Inventário Pratt de crenças religiosas no esporte amplia os domínios de investigação sobre as crenças religiosas pela introdução do conceito e pesquisa sistemática da crença ético-moral.

- A crença ético-moral denota uma evolução da crença intelectual, caracterizada pela resolução dos conflitos inerentes a este domínio, indo de encontro aos conceitos e concepções de JUNG (1998) sobre a evolução do ego no sentido da integração do self.

As crenças intelectual e ético-moral estariam vinculadas a aspectos mais conscientes, já as crenças primitiva e emocional estariam associadas com aspectos mais inconscientes, sujeitas a um menor controle egóico, vinculadas a reações orgânicas e processos somáticos, não abordados no âmbito deste estudo e que precisam ser investigadas.

- As percepções dos atletas sobre as crenças religiosas alinham-se às concepções estabelecidas por PAIVA (1998), PORTNOI (1999), caracterizadas como estratégias de coping ao stress provocado pela doença e a dor. Caracterizadas nesta pesquisa como estratégias e mecanismos de enfrentamento as pressões internas, externas inerentes às adversidades do esporte de alto nivel de competição e desempenho.

- Há evidências de que conflitos psicológicos podem estar associados com menores escores de lócus de controle interno.

- Verificaram-se tendências ao lócus de controle interno, maior para as crenças: primitiva e ético-moral e menor a crença intelectual e no ateísmo.

- $\quad \mathrm{Na}$ percepção dos atletas a crença primitiva, vivenciada como manifestação natural da espiritualidade e da religiosidade, associa-se com maiores escores de lócus de controle interno.

- Foram encontradas diferenças de escores, estatisticamente significativas, favorável ao lócus de controle interno, maior entre os atletas polivalentes e valores médios menores entre os pivôs.

- Foram encontradas diferenças de escores, estatisticamente significativas, favorável ao lócus de controle externo sorte-azar, maior para os atletas mais jovens e menor para os atletas de maior idade. 
- Foram encontradas diferenças significativas de escores de lócus de controle externo sorte-azar, maior no sexo feminino e menor no masculino.

- Há evidencias de que a religiosidade voltada para a internalidade, associase com maiores escores de lócus de controle interno, pois atletas quando em situações criticas, rezam buscando manter o equilibrio interno e as vitórias, revelaram maiores escores de lócus de controle interno.

- Há evidencias de que a religiosidade voltada para a externalidade, associase com menores escores de lócus de controle interno, pois atletas quando em situações críticas, rezam clamando por ajuda e invocando proteção divina, revelaram menores escores de lócus de controle interno.

- Aspectos psicológicos moldam o comportamento e o posicionamento dos atletas, podendo constituir-se como fatores diferencias na preparação dos atletas e na superação de dificuldades no esporte.

\subsection{Recomendações para estudos futuros}

- O uso da Escala multidimensional do lócus de controle do esporte é recomendado no âmbito da pesquisa básica em psicologia do esporte, ressaltando-se a necessidade do desenvolvimento de novos estudos e aplicações do instrumento em outras modalidades esportivas.

- Que nas pesquisas envolvendo o lócus de controle e as crenças religiosas, sejam considerados aspectos qualitativos e quantitativos.

- Que nos estudos com a Escala multidimencional de lócus de controle do esporte, outros instrumentos psicológicos sejam utilizados, objetivando embasar futuros programas de intervenção psicológica no esporte.

- Investigar as relações que se estabelecem entre o lócus de controle, a saúde psíquica e aspectos orgânicos no desempenho dos atletas.

- Não aplicar a Escala de lócus de controle do esporte de forma reducionista, pois apenas fornece bases para a abordagem de um fenômeno complexo.

- Não aplicar o Inventário Pratt de Crenças Religiosas de forma reducionista, pois apenas fornece bases para abordar a complexidade do fenômeno. 


\section{REFERÊNCIAS}

AUGRAS, M. Devoções "populares": arcaismo ou pós-modernidade? In: Seminário de psicologia e senso religioso, 4., 2002. Caderno de resumos... Săo Paulo: Programa de Pós-graduação do Instituto de Psicologia, 2002.

BALAGUÉ, G. La Periodizacion del entrenamiento psicológico. In: Simpósio Internacional de Psicologia do Esporte 2001. Anais... São Paulo: USP, Grupo de estudos e pesquisas em psicossociologia do esporte, 2001.

BIDDLE, S.; HANRAHAN, S. Attributions and attribution style. In: DUDA J. (Ed.) Advances in sport and exercise psychology measurement. Morgantown: Fitness Information Technology,1998 p.3-20.

BRANDÃO, J. S. Mitologia grega. 14. ed. Rio de Janeiro: Vozes, 1998. 3v.

BROMBERGER, C. Las multitudes desportivas: analogia entre rituales desportivos y religiosos. Revista digital, Buenos Aires, n. 29, p. 1-3, 2001. Disponivel em: <http://www.efdeportes.com/efd29/ritual2.htm> acesso em: 25 jun. 2002.

CALIFORNIA STATE UNIVERSITY. Department of Psychology. Julian B. Rotter: The social learning theory. Disponivel em: <http://psych.fullerton.edu/ jmearns/rotter.htm>. Acesso 17 de nov. 2003.

CASCUDO, L. C. Superstição no Brasil. 4. ed. São Paulo: Global, 2001.

CONFEDERAÇĀO BRASILEIRA DE HANDEBOL. História do handebol, seleções nacionais.Disponivel em :<http://www.brasilhandebol.com.br>. Acesso em:15 abr. 2004.

DELA COLETA, J. A. A escala de locus de controle interno-externo de Rotter: um estudo exploratório. Arquivos brasileiros da psicologia. Rio de Janeiro, v. 31, n.4, p. 167-181,1979. 
DELA COLETA, M. F. Escala multidimensional de locus de controle de Levenson. Arquivos Brasileiros da Psicologia. Rio de Janeiro, v.32, n. 2, p. 7997, 1987.

Locus de controle da saúde. In: DELA COLETA M. F. (Org.) Modelos para pesquisa e modificação de comportamentos de saúde: teorias estudos instrumentos. Taubaté: Cabral 2004, p. 199-252.

FERREIRA, A. B. H. Novo Dicionário Aurélio Séc. XXI. 3. ed. São Paulo: Nova Fronteira, 1995.

FERSTER, C. B.; CULbeRSTSON, S.; PERROTT B. M. C. Princípios do comportamento. São Paulo: Hucitec, 1978.

FREITAS, M. H. Crenças religiosas e personalidade em estudantes de psicologia: um estudo por meio do questionário Pratt e do método de Rorschach. 2002. 275f. Tese (Doutorado em Psicologia) - Instituto de Psicologia, Universidade de Brasilia, Brasilia.

FREUD, S. (1914). Totem e tabu e outros trabalhos. In Edição standard das Obras psicológicas completas de Sigmund Freud. Rio de Janeiro: Imago, 1972 v. 8, p $125-192$.

GAMA, W. Caracteristicas sociais do jogador de futebol profissional da primeira divisão do Estado de São Paulo. 1990. 70f. Dissertação (Mestrado em Educação Física) - Escola de Educação Física e Esporte, Universidade de São Paulo, São Paulo.

GIOVANETTI, J. P. A representaçāo da religião na pós-modernidade. In: Seminário de psicologia e senso religioso, 4., 2002. Caderno de resumos... São Paulo: USP, Programa de Pós-graduação do Instituto de Psicologia, 2002.

GOLDEN, M. Sport and society in Ancient Greece. New York: Cambridge University Press, 1998. 
HAIR, J. H.; ANDERSON,R. E.; TATHAN, R. L.; BLACK, W. C. Multivariate data analysis. 5. ed. New Jersey: Prentice Hall, 1998.

HALL, C. S.; LINDZEY, G.; CAMPBELL, J. B. Teorias da personalidade. Porto Alegre: Artes Médicas, 2000.

HELLENIC MINISTRY OF CULTURE . Deméter e Perséfone (440 - 430 a.C). Baixo-relevo, Museu Arqueológico de Eleusis. Apresenta imagens de achados arqueológicos em sítios da Grécia. Disponivel em: <http://www.culture.gr/ 2/21/214/21405m/00/lm05m024.jpg >. Acesso em: 23 set. 2004.

HIGGS, R. J. Sport and religion and religion and sport: review essay. Journal of the philosophy of sport, Champaign, Human kinetics, v.23, p. $104-09,1996$.

HOUAISS, A. Dicionário Houaiss da Língua Portuguesa. Rio de Janeiro: Objetiva, 2001, p. 1777 (lócus).

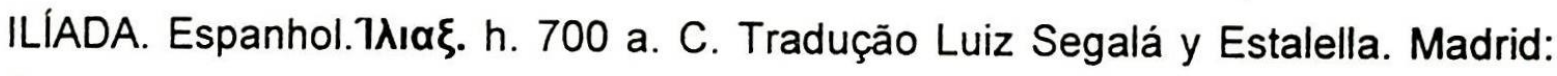
Jorge A. Melsa, 1999.

INSTITUTO BRASILEIRO DE GEOGRÁFIA E ESTATÍSTICA - IBGE. Ministério do Planejamento. Censo Demográfico 2000: Apresenta dados estatísticos sobre religiōes no Brasil. Disponivel em: <http://www.ibge.gov.br/home/ estatistica/populacao/censo2000/populacao/censo2000/população/religião_censo 2000pdf>. Acesso em 23 abr. 2004.

JONES, M. Locus of control and superstitious behavior: a visit to the putting green. In: Annual Arkansas symposium for psychology students, 13.,2001. Hendrix News Release. Arkansas: Hendrix College, 2001. Disponivel em: <http://www.hendrix.edu/News/oldreleases/psycholo... >. Acesso em: 9 out. 2001.

JUNG, C. G. (1964). O homem e seus símbolos. 14., ed. Rio de Janeiro: Nova Fronteira, 1996. 
(1971). Psicologia e religião oriental. $5^{\text {a }}$ ed. Petrópolis: Vozes, 2001.

(1976). Aion estudos sobre o simbolismo do si-mesmo. 5., ed.

Petrópolis: Vozes, 1998 317p.

KREIDER, A. J. Prayers for assistance: as unsporting behavior. Journal of The Philosophy of Sport, Champaign, Human kinetics, v.30, p. $17-25,2003$.

LEVENSON, H. Multidimensional locus of control in psychiatric patients. Journal of Consunting and Clinical psychology, Columbia, v. 41, n. 3, p. 397- 404, 1973.

MURARO, R. M. Prefácio. In: J. S. BRANDÃO, Mitologia Grega. 2. ed. Rio de Janeiro: Vozes, 1988, v. 2.

MUSEO GREGORIANO ETRUSCO. ARKESILAS, 555 a. C. Atlas e Prometeu: Kylix figurado alusivo aos mitos de Atlas e Prometeu. Coleção do museu do Vaticano em imagens. Disponivel em <http://www.christusrex.org/www1/vaticano/ ET1-Etrusco.html> Acesso em: 8 set. 2003.

NERY, M. A. C. Grupos esportivos de handebol : um estudo sobre a intersubjetividade. 2003. 16I f. Dissertação (Mestrado) - Escola de Educação Física e Esporte, Universidade de São Paulo, São Paulo.

NEWTON, N.; MINUTAGLIO, B. Locker room mojo: true tales of superstition in sport. Texas: Middlefork Press, 1999.

ODISSÉIA. Português. Odisséia: Homero, 700 a. C. Tradução de Manuel Odorico Mendes. São Paulo: Martin Claret, 2003.

OERTEL, M. Die angst und ihre bewältigung beim sporttauchen. Berlin: Humbolt Universität zu Berlin. Institut für Sportwissenschaften. Disponivel em: $<h \mathrm{htp}: / / \mathrm{w} w \mathbf{w}$.ortelius.de/tauchen_angst/examen.pdf>. Acesso em: 19 jun. 2003. 
OLGA'S GALLERY. The abduction of Proserpine. Oleo, Rembrandt (1631). Gemäldegalerie, Berlin. Disponivel em: <http://www.abcgallery.com/R/ rembrandtrembrandt104.html>. Acesso em: 23 set. de 2004.

OSTROW, A. C. Diretory of psychological tests in the sport and exercice sciencies. 2nd. Ed. Morgantown: Fitness Information Technology, 1996.

PAIVA, G. J. AIDS, psicologia e religião: o estado da questão na literatura psicológica. Psicologia: teoria e pesquisa, Brasília , v. 14, n. 1, p. 027-034, 1998.

PEREIRA, J. C. Análise de Dados Qualitativos: estratégias metodológicas para as ciências da saúde, humanas e sociais. São Paulo: EDUSP, 1999.

PORTNOI, A. G. Dor, stress e coping : grupos operativos em doentes com síndrome de fibromialgia.1999. 256f. Tese (Doutorado em Psicologia) - Instituto de Psicologia, Universidade de São Paulo, São Paulo.

PRATT, J. B. The psychology of religious belief. New York: the Macmillan, 1907.

The religious consciousness: a psychological study. New York: the Macmillan, 1923.

ROMANO, D. G. (1985) Exploring 5000 Years of Athletics. Expediction magazine. The Real History of the Ancient Olympic Games. University of Pennsylvania. Disponivel em <http://www.museum.upenn.edu/new/Olympics/ olympiccredits.shtml> acesso em: 22 mar 2004.

ROTTER, J. B.; CHANCE, J. E.; PHARES, E. J. Applications of a social learning theory of personality. New York: Holt, Rinehart and Winston, 1972.

SCHILLING, G.; GUBELMANN, H. Enhancing performance with mental training. In: BIDDLE, S. J. H. (Ed.) European perspectives on exercise and sport psychology. Champaign: Human Knetics, 1995, p. 179-217. 
SIMOES, A. C. Estudo do comportamento de liderança dos técnicos de handebol.1987. 74f. Dissertação (Mestrado em Educação Física) - Escola de Educação Fisica e Esporte, Universidade de São Paulo, São Paulo.

Ideologia de liderança no esporte: uma visão do "ideal próprio" dos técnicos e "real equipe" dos Atletas, 1996. 162f. Tese (Livre Docência em Educação Física) - Escola de Educação Física e Esporte, Universidade de São Paulo, São Paulo.

Psicossociologia aplicada ao esporte: contribuição para sua compreensão. Revista Paulista de Educação Física, v. 13, p. 88 - 97, 1999.

. Esporte de Performance. In; KISS, M. A. P. DM (Org.). Esporte e exercício: avaliação e prescrição. São Paulo: Roca, 2003, p. 249-288.

SIMÕES, A. C.; CONCEIÇÃO, P. F. M. As Brincadeiras os jogos e os esportes sob a concepção de Winnicott : Proposta Multidisciplinar de prevenção primária as drogas na escola publica. São Paulo: editora, 2004.

SIMÕES, A. C.; CORTEZ, J. A. A.; CONCEIÇÃO, P. F. M. Mulher e esporte de competição e de rendimento: as várias fases do social, do biológico e do psicológico. In: A.C. SIMÕES, J. D. KNIJNIK (Orgs.). O mundo psicossocial da mulher no esporte: comportamento, gênero e desempenho, São Paulo: Aleph, 2004.

SINGER, R. N.; ORBACH, I. Persistence, excellence and fulfillment. LIDOR, R.; BAR-ELI, M. (Ed.) Sport psychology: Linking theory and practice. Morgantow: Fitness information Technology, 1999 p. 167-190.

TAMAYO, A. Validade Fatorial da escala Levenson de Lócus de Controle. Psicologia: teoria e pesquisa, Brasilia, v. 5, n. 1, p. 111-122, 1989. 
UNIVERSITY OF VICTORY. A união de Hades e Perséfone. llustração francesa, séc. XV. Departamento de estudos gregos e romanos. Disponível em: $<$ http://web.uvic.ca/grs/bowman/myth/images/haifa/h17.jpg>. Acesso em: 23 set. 2004.

UNIVERSO ON LINE. Delegação chinesa leva o trigo durante a cerimônia de encerramento dos Jogos Olímpicos na Grécia 2004. Agência Reuters. Foto disponibilizada na pagina de esportes Olimpiadas 2004. . Disponivel em: <http://eventos.esporte.uol.com.br/olimpiadas/fotos/ >. Acesso em: 29 de ago. 2004.

VASCONCELLOS, E. G.; DE ROSE, Junior D. Perfis de stress e atribuição causal em jogadoras da seleção brasileira de basquetebol: In Congresso interno do Instituto de Psicologia, 1., 1991, São Paulo. Anais Eletrônicos ... São Paulo: IPUSP, 1991. Disponivel em: >http://www.usp.br/eef/esporte/comp.htm<. Acesso em: 16 mar. 2003.

VOLKWEIN, K. A. E. Ethics and top-level sport: a paradox? International Review of Sociology of Sport. München, v. 30, n. 3+4, p. 311-319, 1995.

ZOHAR, D.; MARSHALL, I. QS: inteligência espiritual: $O$ " $Q$ " que faz a diferença. Tradução Ruy Jungman. Rio de Janeiro: Record, 2000. 


\title{
ANEXO I - Parecer do Comitê de Ética
}

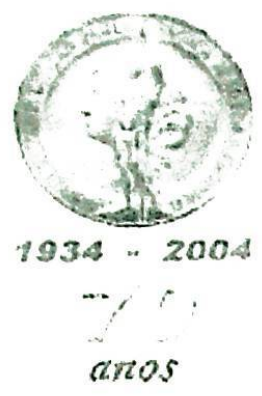

\author{
UNIVERSIDADE DE SÃO PAULO
}

ESCOLA DE EDUCAÇÃO FÍSICA E ESPOR'TE

aros

OF.CEP/422004/EEFE/020604

Parecer CEP - Projeto $n^{\circ} 49$

O Comitê de Ética em Pesquisa da EEFE-USP, em reunião de 28/05/04, apreciou o projeto de pesquisa intitulado "Perfil Perséfone: um estudo sobre crenças religiosos e lócus de controle de atletas de handbol", sob sua responsabilidade e considerou-o aprovado.

Atenciosamente.

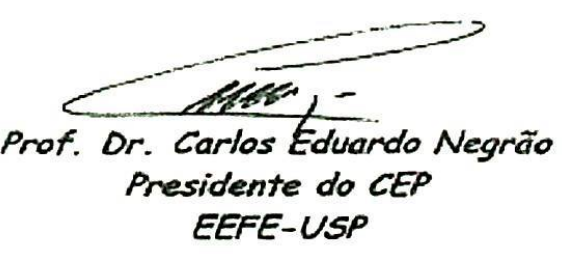

Ao

Ilmo. Sr.

Prof. Dr. Antonio Carlos Simões

Departamento de Esporte

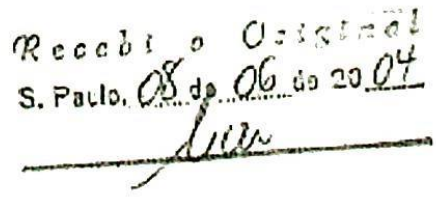




\section{ANEXO II - Termo de consentimento livre e informado do atleta}

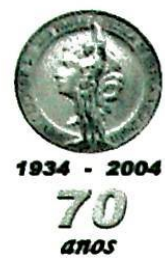

\section{UNIVERSIDADE DE SÃO PAULO}

\section{ESCOLA DE EDUCAÇÃO FÍSICA E ESPORTE}

\section{Prezado (a) Atleta,}

Você está sendo convidado(a) a participar do projeto "Perfil Perséfone no Esporte" um estudo sobre religiosidade e crenças pessoais de atletas, que esta sendo realizado por Paulo Felix Marcelino Conceição, aluno do curso de pós-graduação, nível mestrado, na Escola de Educação Física e Esporte da Universidade de São Paulo sob orientação do Prof. Dr. Antonio Carlos Simões.

Este documento contém todas as informações sobre o estudo que estamos realizando, se concordar assine o documento para que possamos dar prosseguimento à pesquisa.

A pesquisa consiste na aplicação de dois questionários, sua identidade será preservada e não haverá nenhum inconveniente decorrente de sua participação, a qual consideramos muito importante; no entanto, se você desistir a qualquer momento, isso não lhe causara nenhum prejuízo.

$$
\mathrm{Eu},
$$$$
\text { RG }
$$

bairro abaixo-assinado, concordo de livre e espontânea vontade participar do estudo "Perfil Perséfone no Esporte", declaro que obtive todas as informações necessárias e fui esclarecido(a) sobre todos os aspectos de meu envolvimento no projeto.

\section{Estou ciente que:}

I- $\quad$ O estudo se faz necessário em razão da grande importância que as crenças e convicções pessoais exercem sobre os atletas no esporte;

II- $\quad$ Serão aplicados dois questionários e se necessário, suas reaplicações;

III- A participação no projeto não tem por objetivo difundir ou mudar qualquer tipo de crença pessoal e não terá nenhum custo para mim;

IV- Tenho a liberdade de desistir ou interromper a colaboração neste estudo no momento em que desejar, sem necessidade de qualquer explicação.

V- Os resultados obtidos no estudo serão mantidos em sigilo, mas concordo que sejam divulgados em publicações científicas, desde que meu nome seja preservado.

VI- $\quad$ Caso eu desejar, poderei tomar conhecimento dos resultados ao final desta pesquisa.

$$
\text { São Paulo, }
$$
de de 2004

Atleta:

Pesquisador:

Testemunha

$$
\text { Paulo Félix Marcelino conceição }
$$

Nome: RG 


\section{ANEXO III - Termo de consentimento livre e informado do técnico}

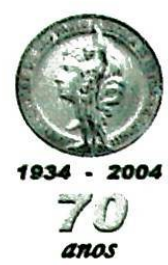

\section{UNIVERSIDADE DE SÃO PAULO}

ESCOLA DE EDUCAÇÃO FÍSICA E ESPORTE

\section{Prezado(a) Técnico(a)}

Venho por meio deste solicitar sua autorização para realizar junto às equipes de Handebol o projeto "Perfil Perséfone no Esporte". Pesquisa que esta sendo elaborada por Paulo Felix Marcelino Conceição - aluno do curso de pós-graduação, nível mestrado, na Escola de Educação Física e Esporte da Universidade de São Paulo, sob orientação do Prof. Dr. Antônio Carlos Simões, que tem por objetivo obter dados sobre os sentimentos religiosos e crenças pessoais dos atletas.

A pesquisa tem finalidade acadêmica e será publicada nos meios científico e especializado nas áreas de esporte e psicologia, consiste na aplicação e possível reaplicação de dois questionários, aos quais é facultada a livre participação das atletas. A identidade dos mesmos será preservada e não haverá nenhum inconveniente decorrente da participação na pesquisa.

Desde já agradecemos sua colaboração pela disponibilidade das atletas.

São Paulo, de de 2003

Técnico

Pesquisador

Paulo Felix Marcelino Conceição

Orientador:

Prof. Dr. Antonio Carlos Simões 
ANEXO IV - Escala de lócus de controle do esporte

\section{INSTRUÇÕES \\ ESCALA I-E APP DO ESPORTE}

Esta é uma pesquisa sobre a maneira como diferentes e importantes acontecimentos afetam os atletas no esporte. Cada frase é seguida por simbolos representativos de expressões faciais "carinhas". Por favor, leia atentamente cada questão e faça um circulo no símbolo que melhor expressar sua opinião pessoal. Certifique-se de escolher aquela resposta que realmente represente aquilo que você acredita, e não aquilo que você acha que deveria ser. Este instrumento avalia crenças pessoais, obviamente não há respostas certas ou erradas.

CONCORDO TOTALMENTE

CONCORDO

CONCORDO PARCIALMENTE
DISCORDO TOTALMENTE

DISCORDO

DISCORDO PARCIALMENTE

ANTES DE PROSSEGUR: Preencha o termo de conssentimento em anexo.

Complete 0 quadro abaixo. Não vire a folha até que seja solicitado.

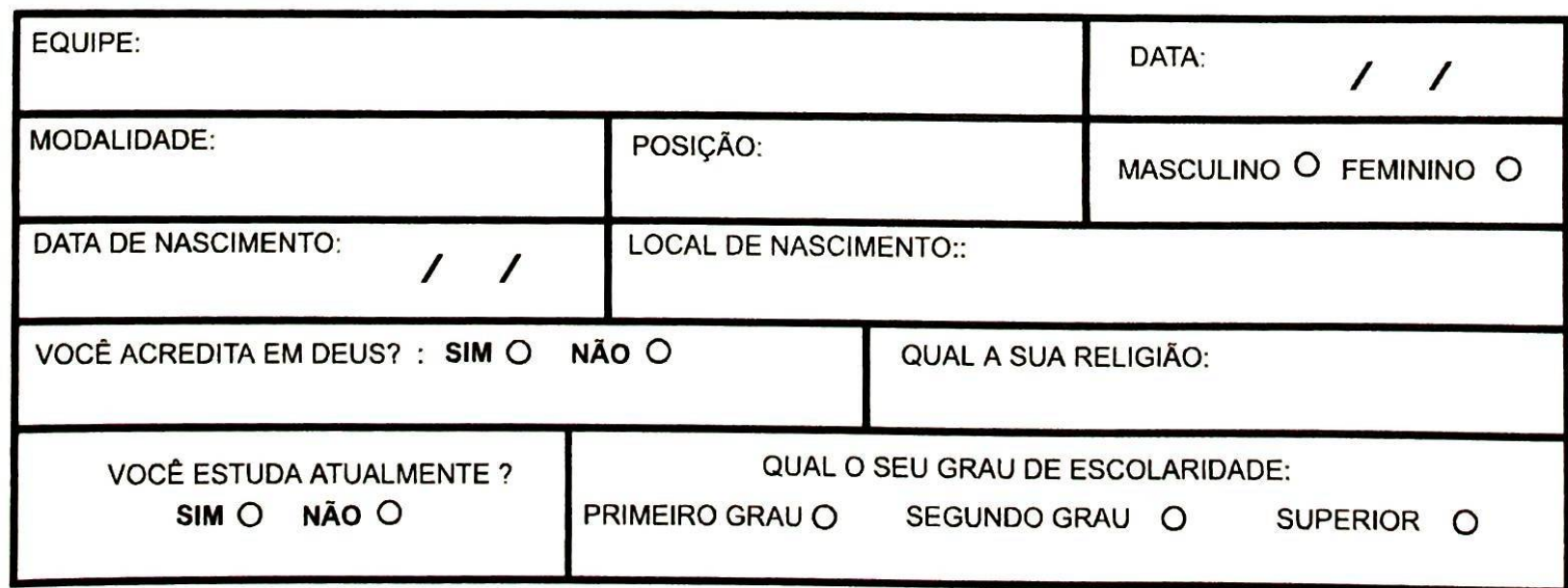




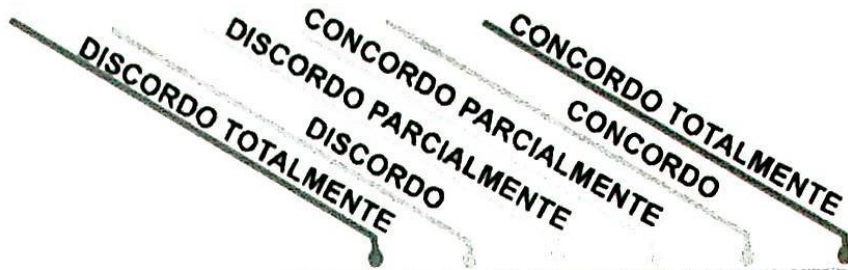

Para mim, a instabilidade na carreira esportiva resulta de dificuldades do proprio atleta.

Freqüentemente, quando eu tenho um pressentimento de que algo vai acontecer, de fato acontece.

Se as pessoas gostam de um atleta, é porque simplesmente gostam. Dai, não adiante se esforçar para ser agradável.

Se eu me dedicar bastante, posso ter sucesso no esporte.

O sucesso no esporte é questão de muito trabalho e persistência. A sorte tem pouco ou nada a ver com isso.

Aqueles que tem sucesso no esporte, realmente tiveram muita sorte.

São momentos oportunos, que fazem de um atleta qualquer, um super atleta.

Para alcançar uma posição privilegiada no esporte, vou precisar da ajuda de pessoas influentes.

Se eu tiver sucesso na carreira esportiva, será principalmente por causa da minha capacidade.

Para ser um atleta de sucesso, depende de estar no esporte certo, na equipe certa e na hora certa.

Se eu tiver sucesso no esporte, será por causa das pessoas que cuidaram da minha carreira.

Muitas coisas que afetam a carreira de um atleta acontecem por acaso.

O atleta, na maioria das vezes, tem que agir segundo os interesses de outras pessoas.

Se eu vou ou não, sofrer um acidente durante o desenvolvimento de um jogo, isso é uma questão de sorte.

Minha carreira no esporte depende muito de outras pessoas.

Durante um jogo qualquer, na hora "H", é Deus quem mostra para - atleta a direção certa.

Na maioria das vezes, não dá para entender porque os políticos agem desta ou daquela forma com relação ao esporte.

É raro encontrar um resultado de jogo injusto, o que existe, são atletas mal preparados.

Um fator importante no esporte, assim como na vida, é tomar as decisões certas.

Apesar de ter boa capacidade para o esporte, só conseguirei chegar onde eu quero se tiver ajuda de pessoas importantes.

O atleta que segue corretamente uma carreira bem planejada, pode ficar tranqüilo quanto ao seu futuro.

Na maioria das vezes, são os detentores do poder esportivo, que decidem os rumos da vida do atleta.

Posso decidir como vai ser o meu futuro, de acordo com aquilo que eu mesmo faço no presente.

Se for meu destino, eu me darei bem no esporte.
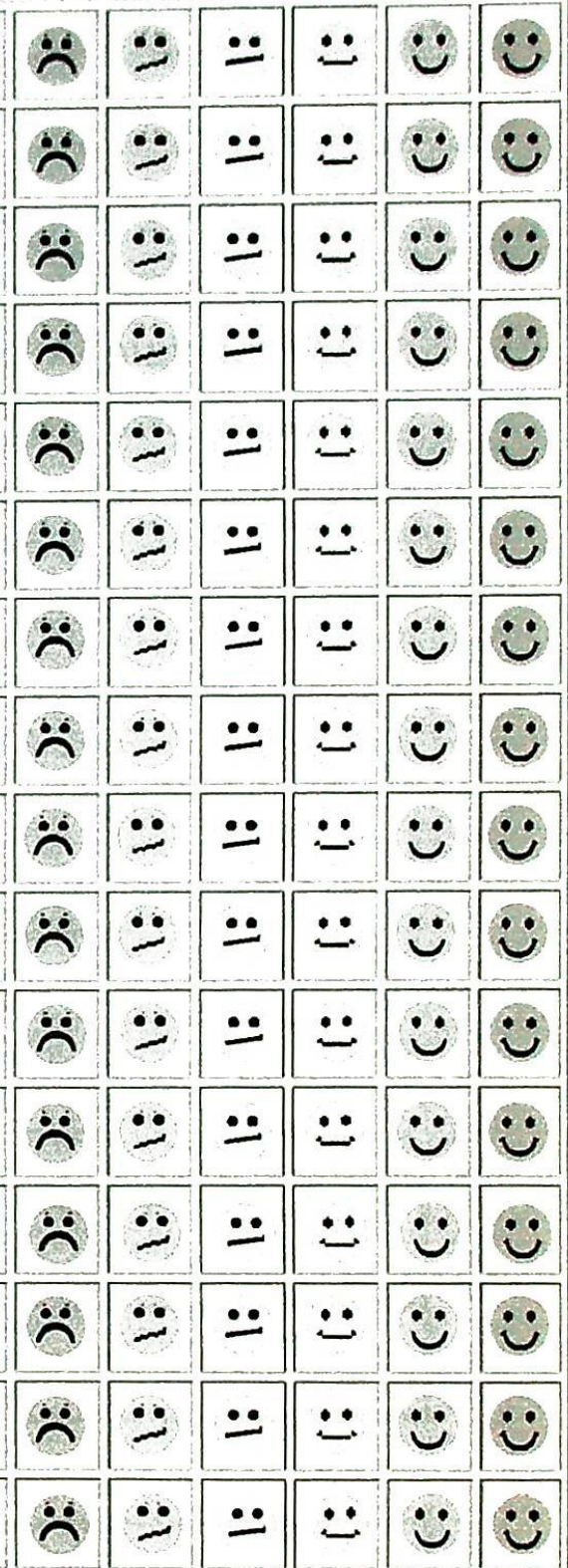

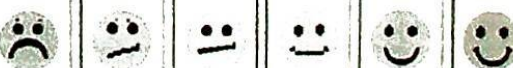

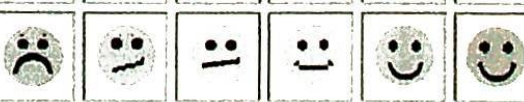

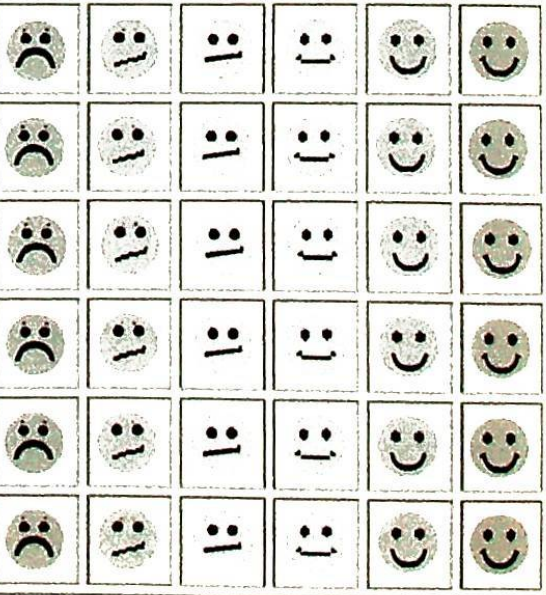




\section{ANEXO V - Inventário Pratt de crenças religiosas no esporte}

\section{INSTRUÇÕES}

\section{INVENTÁRIO DE CRENÇAS RELIGIOSAS NO ESPORTE}

Questóes adaptadas do Questionario Pratt de crenças religiosas (PRATT,1907; ABREU e SILVA,1998; FREITAS, 2002)

A seguir você encontra algumas questões sobre crenças religiosas, certifique-se de responde-las refletidamente de acordo com sua experiência pessoal, procure não dar respostas filosóficas ou generalizantes. A maioria das questões trazem alternativas de resposta, você deve escolher uma ou mais alternativas, apenas tome o cuidado de justificar suas respostas de acordo com aquilo que você pensa.

Complete o quadro abaixo. Não vire a folha até que seja solicitado. ANTES DE PROSSEGUIR: Preencha o termo de conssentimento em aneXo.

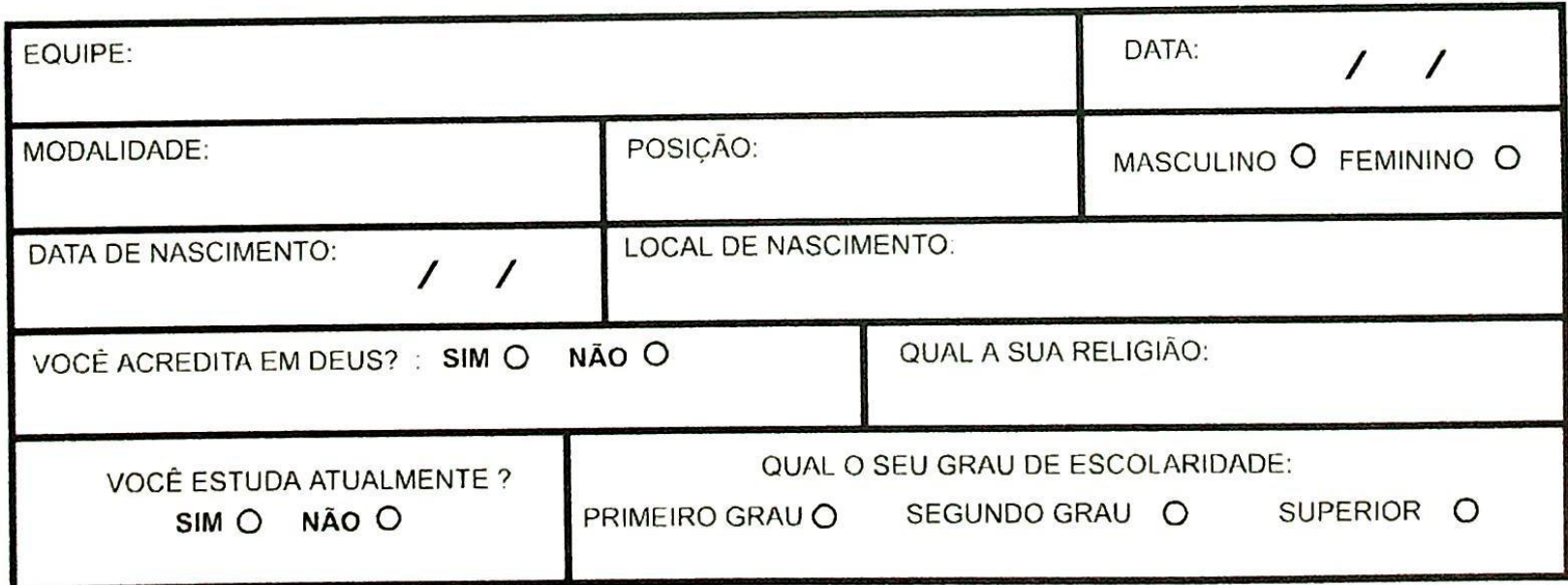

SUAS RESPOSTAS SÃO CONFIDENCIAIS

CASO O ESPAÇO DESTINADO AS SUAS RESPOSTAS NÃO SEJA SUFICIENTE, UTILIZE O ESPÇO NO VERSO DA FOLHA. 


\section{ANEXO V - Inventário Pratt de crenças religiosas no esporte (continuaçăo)}

1 O que a religião significa para você pessoalmente ? É ...

$\square$ Uma crença de que algo existe? Descreva com é esta crença.

$\square$ Vivenciar, sentir e/ou experienciar a presença de Deus? Como é esta experiência?

$\square$ Uma atitude do homem para difundir a idéia de Deus e as coisas que são corretas? Explique?

$\square$ Respeitar as tradiçōes e obedecer às figuras de autoridade? Quais?

$\square$ Outro significado? Explique?

Complete a sua resposta:

\section{Como é Deus para você ?}

$\square$ Uma pessoa. Então, o que significa para você dizer que ELE é uma pessoa?

$\square$ Aquele que da sentido ao universo, porque o homem só pode ter sido criado por Deus. Explique?

$\square$ Uma energia. Então, como você percebe esta força e/ou energia?

$\square$ Um principio que orienta para aquilo que é correto e aquilo que deve ser feito. Explique?

$\square$ Outro ? Procure explicar detalhadamente.

Complete a sua resposta:

\section{Você acredita em Deus? É...}

$\square$ Com base em algum fato, prova ou argumento? Se for, qual (is)?

$\square$ Porque você já experimentou ou sentiu SUA presença? Descreva como foi esta experiência.

$\square$ Com base na autoridade de um livro sagrado, ou de alguma pessoa? Se for, qual (is)?

$\square$ Porque ele significa o agir corretamente, ter e divulgar valores morais? Explique?

$\square$ Outro? Explique:

Complete a sua resposta: 
ANEXO V - Inventário Pratt de crenças religiosas no esporte (continuação)

4.0 Deus é algo real para você, tão real como um amigo terreno, embora diferente? $\operatorname{sim} \square$ às vezes $\square$ não $\square$. Explique:

5.0 Você sente que já experimentou a presença de Deus? sim $\square$ não $\square$. Se sim, descreva o que você quer dizer com "experimentar Sua presença?"

5.1 Se você não teve esta experiência, você aceita o testemunho de outros que dizem ter sentido a presença de Deus? Por favor, responda esta questão com cuidado e o máximo possível de detalhes:

6.0 Você acredita que Deus poderia ajudar a vencer obstáculos no esporte? $\operatorname{sim} \square$ às vezes $\square$ não $\square$. Explique:

6.1 E nas derrotas, Deus teria alguma participação? $\operatorname{sim} \square$ às vezes $\square$ não $\square$ Explique :

6.2 Deus seria um suporte psicológico para o atleta? $\operatorname{sim} \square$ às vezes $\square$ não $\square$. Como é para você? 
ANEXO V - Inventário Pratt de crenças religiosas no esporte (continuaçăo)

7.0 Vocè reza para obter a vitória nas competiçōes esportivas? $\operatorname{sim} \square$ às vezes $\square$ năo $\square$. Explique:

7.1 E quando as coisas não dão certo. Você faz orações? $\operatorname{sim} \square$ às vezes $\square$ não $\square$. Explique:

8.0 Para você, o que significa "espiritualidade?"

9.0 Se você tivesse que se tornar inteiramente convencido(a) de que Deus não existe, isto faria uma grande diferença em sua vida? Explique como seria afetada cada uma destas esferas:

Com relação à felicidade:

- Com relação à moralidade:

- Com relação à carreira esportiva:

10 Você acredita que o esporte seria uma forma de louvar Deus e levar sua palavra a outras pessoas? $\operatorname{sim} \square$ às vezes $\square$ não $\square$. Explique: 


\title{
APÊNDICE 1 - Material entregue à comissão julgadora sobre a avaliacão do inventário de crencas religiosas no esporte: primeira fase do processo de construcão do instrumento
}

\author{
UNIVERSIDADE DE SÃO PAULO \\ ESCOLA DE EDUCAÇÃO FÍSICA \\ DEPARTAMENTO DE ESPORTE
}

\section{QUESTIONÁRIO PRATT DE CRENÇAS RELIGIOSAS}

O presente instrumento de pesquisa - "Questionário Pratt Adaptado - Crenças Religiosas” (QPA-CR) foi originalmente criado por J. B. Pratt em 1904, tendo sido traduzido no Brasil por Abreu e Silva (1998) e posteriormente adaptado por Freitas (2002) em um estudo denominado "Crenças Religiosas e Personalidade em Estudantes de Psicologia - Um estudo por meio do questionário Pratt e do Método de Rorschach".

Neste sentido, Eu, Paulo Felix Marcelino Conceição - aluno do curso de pósgraduação - nível mestrado - na Escola de Educação Física e Esporte da Universidade de São Paulo, pretendo utilizar este instrumento para avaliar os tipos de crença religiosa em atletas de futebol.

A estética de apresentação do instrumento teve que ser alterada, visando atender as demandas de uma metodologia que viabilize sua aplicação no esporte, tendo em vista que na adaptação realizada por Freitas o questionário não inclui espaço para respostas, uma vez que, as mesmas foram digitadas em folhas avulsas. $\mathrm{O}$ instrumento foi redesenhado, incluído-se algumas readaptações, espaços para respostas e substituindo-se alguns termos por palavras sinônimos do dicionário Aurélio, buscando uma maior compreensão por parte de populações menos letradas.

Assim considerando gostariamos que vossa senhoria pudesse emitir um parecer em relação às questões aqui formuladas. 
APÊNDICE I - Material entreque para à comissão iulgadora na elaboracăo do Inventário de crencas religiosas no esporte (continuacăo)

\section{"QUESTIONARIO PRATT DE CRENÇAS RELIGIOSAS - ESPORTE" (QPCRE)}

Caro atleta vocè acredita em Deus? Sim $\square$ Não $\square$. Em caso afirmativo, por favor prossiga. Este inventário faz parte de um estudo sobre crenças religiosas, que esta sendo realizado por Paulo Félix Marcelino Conceição, ahuno do curso de Pós-Graduação em nivel de mestrado na Escola de Educação Física e Esporte da Universidade de São Paulo. Para que o estudo seja bem sucedido é muito importante que você responda todas as questões com sinceridade, procure não fazer generalizações filosóficas, responda detalhadamente com base nas suas experiências pessoais. Caso o espaço destinado à resposta não seja suficiente, por favor utilize o verso da folha tomando o cuidado de identificar a questão.

\section{Não se identifique !}

1.0 O que a religião significa para você pessoalmente?

․ Uma crença de algo existe? Descreva como é esta crença.

ㅁ. Uma experiência emocional? Descreva como é esta experiência.

므 Uma atitude geral da vontade do homem favorável á Deus ou favorável a ética e a moral ?

ㅁ Ou uma outra coisa? Descreva.

Explique sua resposta :

1.1- Se a religião tem vários elementos, qual é para você o mais importante?

2.0 Ao dizer DEUS. O que você quer dizer isso?

S Se DEUS for uma pessoa, o quer dizer isso?

ㅁ Ou DEUS é apenas uma força ? Caso seja, o que quer dizer esta força.

ㅁ. Ou DEUS é uma atitude favorável do universo?

口 Outro significado. Qual?

Explique sua resposta :

2.1- Como você compreende a relação de Deus com a humanidade e com você pessoalmente?

2.2- Se sua posição sobre as duas relações for incerta, por favor declare este fato:

3.0 Por que você acredita em DEUS?E

ㅁ. Com base em algum argumento?

ㅁ Porque já experimentou SUA presença?

Com base na autoridade, tal como, os textos sagrados ou de uma pessoa profética? Explique.

$\mathrm{C}$ Com base em algum outro motivo? Qual?

Justifique sua resposta : 3.1 - Se você acredita em DEUS com base em várias razões, por favor indique cuidadosamente a ordem de sua
importância. 


\section{APÊNDICE I - Material entreque para à comissão julgadora na elaboracão do Inventário de crencas religiosas no esporte (continuacão)}

4.0 Ou vocè não acredita em DEUS tanto quanto quer fazer uso DELE? Explique:

4.1 Você aceita DEUS não tanto como um Ser real existente, mas de preferência, como um ideal pelo qual se vive Explique:

4.2

Se você tivesse que se tornar inteiramente convencido de que DEUS não existe, isto faria uma grande diferença en sua vida - seja em relação à felicidade, a moralidade, ou a outros aspectos? Explique:

DEUS é algo muito real para você, tão real como um amigo terreno, embora diferente?

5.1

Você sente que já experimentou a presença de DEUS? Se for o caso, por favor descreva o que você quer dizer cor "experimentar SUA presença". O que é tal experiência?

De que modo à experiência de DEUS o afeta mental e fisicamente? Vagamente ou faz alguma diferença ? Expliquı

5.3

6.0 Você reza? E, se for o caso, por que? Quer dizer, é puramente por habito e costume social, ou você acredita que DEUS ouve suas preces?

6.1

Se você não teve essa experiència, você aceita o testemunho de outros que reivindicam ter sentido a presença $d$ Deus diretamente? Por favor, responda esta questão com o maior cuidado e com o máximo possível $d$ detalhes.

Em suas preces, você é unilateral ou bilateral - isto é, você sente as vezes que recebe algo de DEUS em suas preces tal como força ou o espírito divino? A oração é uma comunhão real entre você e Deus?

7.0 Para você o que significa "espiritualidade"?

7.1 Descreva uma pessoa espiritual típica :

8.0 Você acredita na imortalidade pessoal?

9.0 Você aceita a Bíblia como autoridade em questões religiosas?

9.1 Sua fé religiosa e a sua vida são baseadas nela? Se for o caso, de que modo sua crença em DEUS e sua vi favorável a ELE e aos companheiros humanos seriam afetadas pela perda da fé na autoridade da Bíbli 


\section{APÊNDICE II - Comissão julgadora do Inventário de crencas religiosas no esporte na primeira fase do processo de construcão do instrumento}

$\mathrm{Na}$ primeira fase de construção do inventário de crenças religiosas no esporte, foram inseridos campos para respostas com espaços formatados e substituídos alguns termos por sinônimos do instrumento originalmente delineado por J. B. Pratt adaptado por FREITAS (2002).

Inicialmente quatro juizes avaliaram este instrumento:

- Myriam Krasilchick

- Luiz Femando Bacchereti

- Sonia Maria da Silva

- Luiza Klein Alonso

Os pareceres iniciais dos juizes encontram-se respectivamente nas paginas: 123 , 124,125 e 126. 
123

APÊNDICE III - Parecer de Myriam Krasilchick

Parecer:

DADOS DO AVALIADOR

Nome:

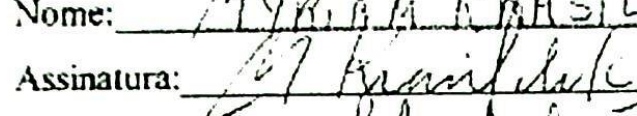

Data $23 / 5 / 03$

Instituiça: Foueldade de Edecacss

Area de Atuação: Siesenco Seypensor

1. Quanto à clareza e adequaçăo das instruçðes:

Concordo $\square$ discordo $\square$

sugestōes:

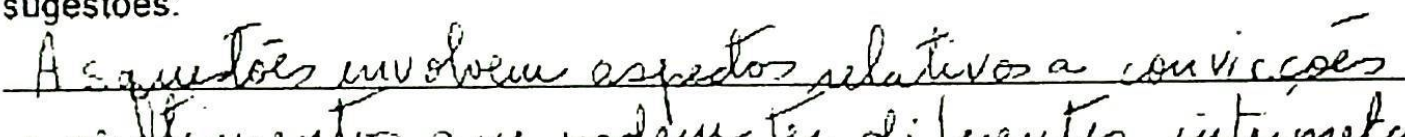

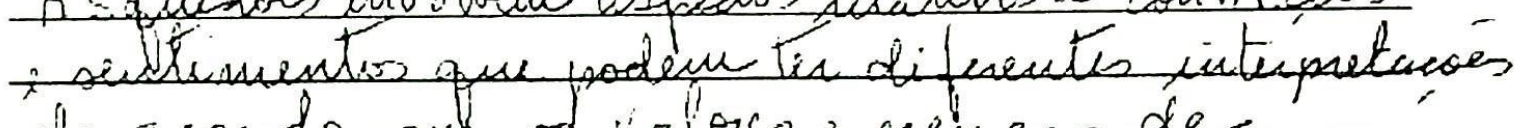
di acosdo oul of vilieres a ciencas dec cada participarate dea perpuisa

2. Quanto à estética do Inventário:

Concordo $\otimes$ discordo $\square$ sugestరes:

Coeso que há unu exceroo de iteses

3. Quanto ao conteudo dos itens do inventário:

Concordo $\square$ discordo $\square$ sugestōes: 


\section{APÉNDICE IV - Parecer de Luiz Fernando Bacchereti}

\section{Parecer:}

DADOS DO NVALIADQR

DADOS DO AVALIADQR
Nome: ${ }_{\text {Assinatura: } C}$

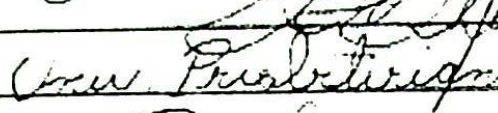

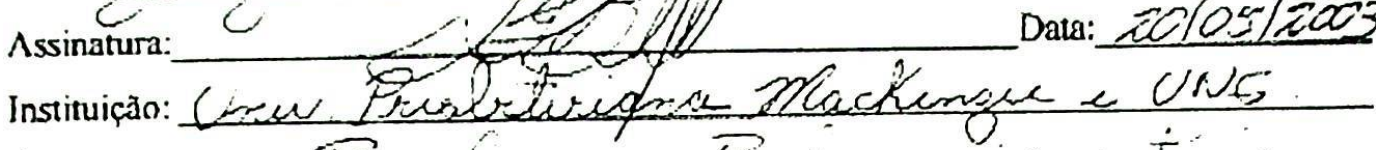

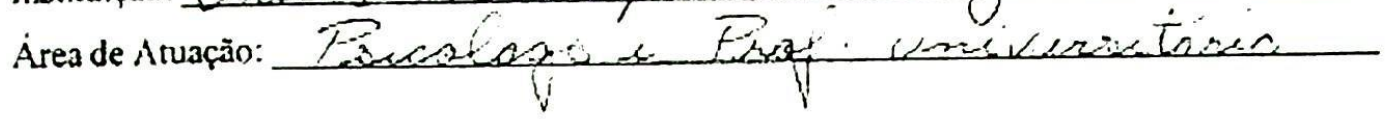

1. Quanto à clareza ê adequaçĩo das instruç̋̉es:

Concordo $\otimes$ discordo $\square$ sugestōes:

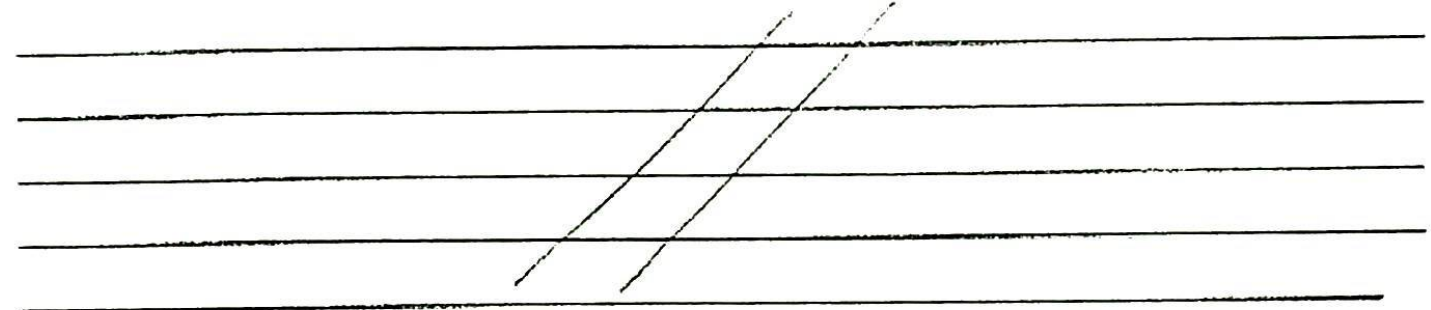

2. Quanto à estética do Inventário:

\section{Concordo $\Omega$ discordo $\square$} sugestōes:

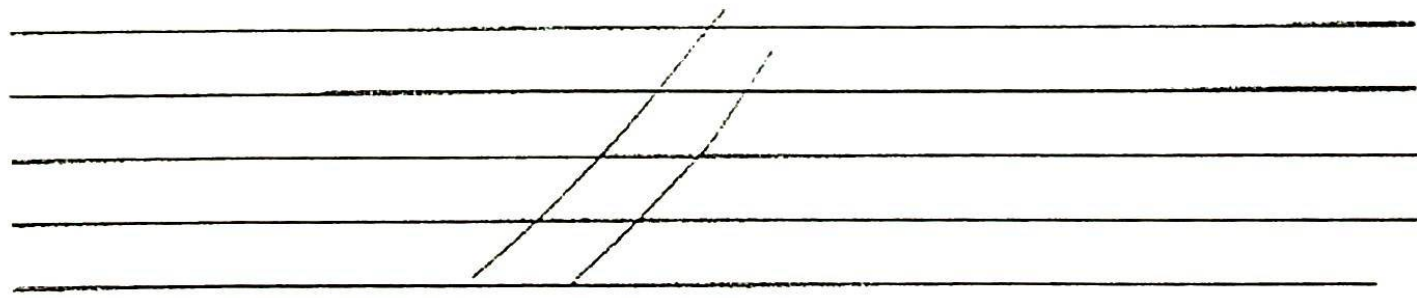

3. Quanto ao conteúdo dos itens do inventário:

Concordo $\square$ discordo $区$ sugestōes:

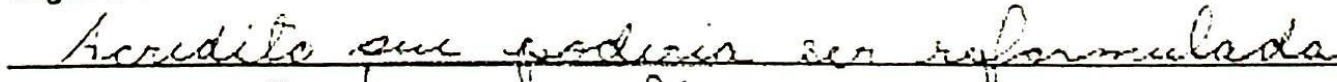

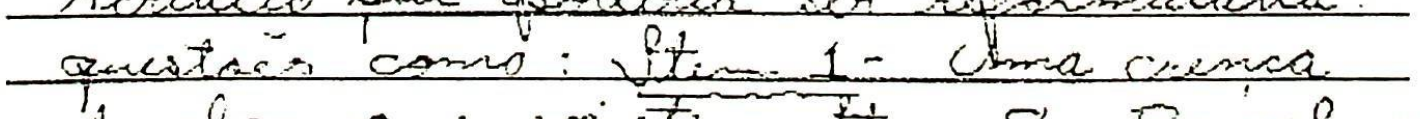

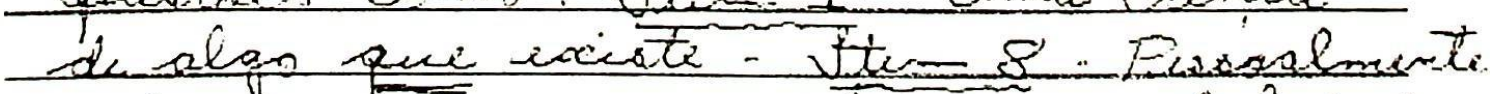

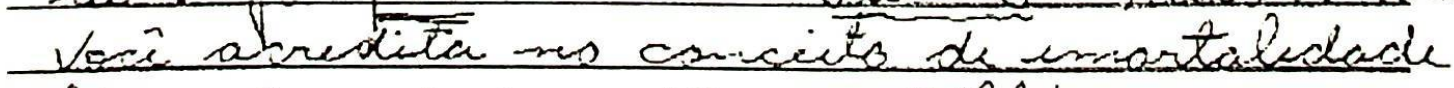

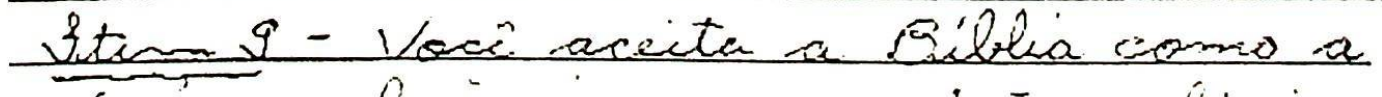

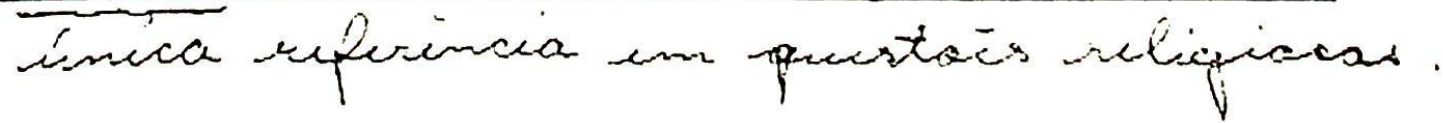




\section{APÊNDICE $V$ - Parecer de Sonia Maria da Silva}

\section{Purecer:}

\section{DADOS DO AVALIADOR}

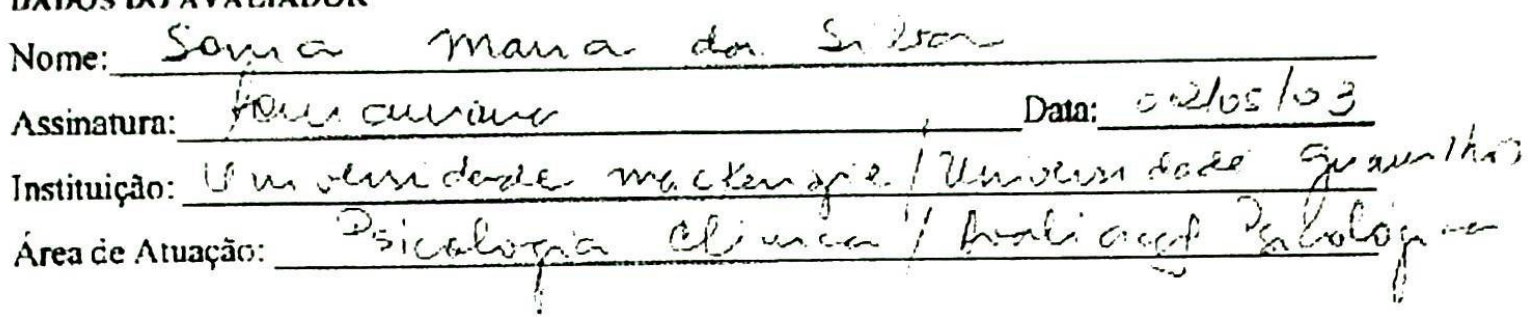

1. Quanto à clareza c adequaçăo das instruçỏes: Concordo sugestoes:

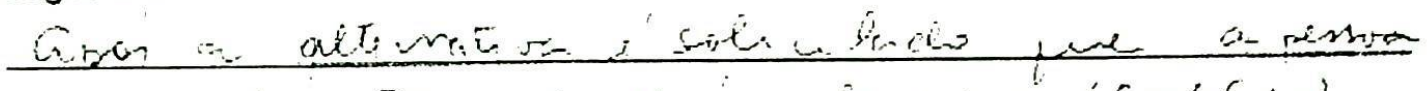

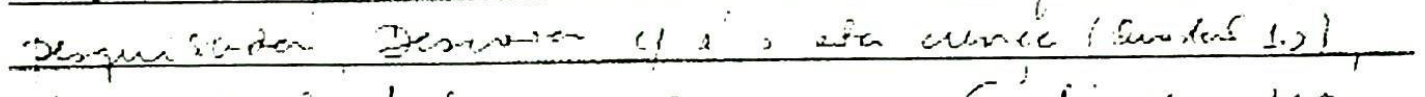

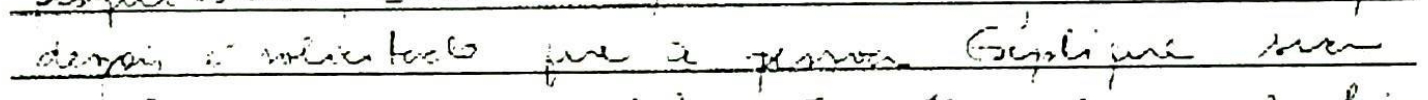

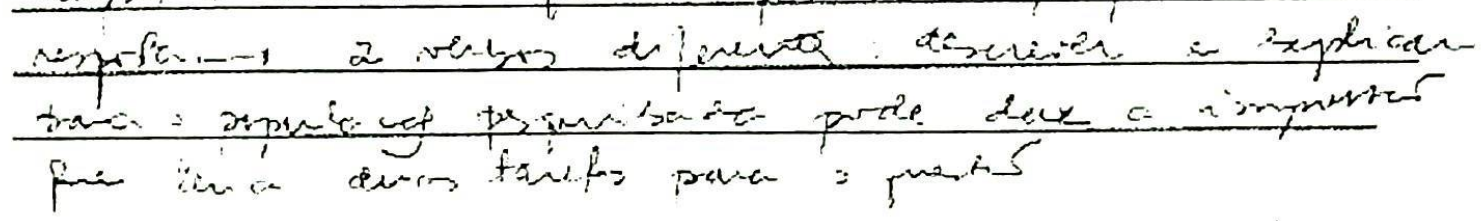

2. Quanto à estética do Inventário: Concordo $\triangle$ discordo $\square$ sugestōes:

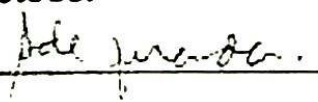

3. Quanto ao conteúdo dos itens do inventário:

Concordo $\square$ discordo $\square$ sugestōes:

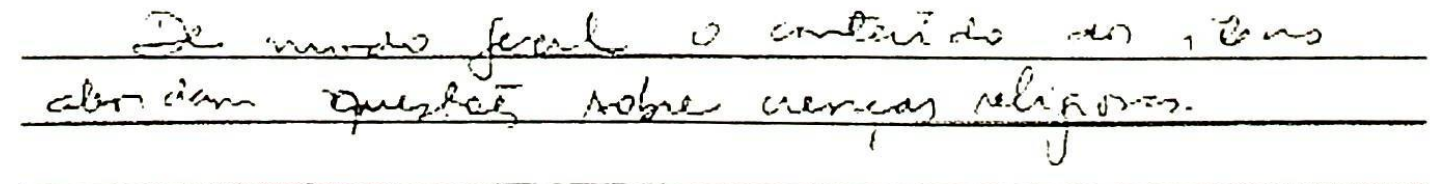


APÊNDICE VI - Parecer de Luiza Klein Alonso

\title{
QUESTIONÁRIO PRATT DE CRENÇAS RELIGIOSAS
}

\author{
Uma análise da validade do instrumento
}

Luiza Klein Alonso

\section{Considerações Gerais:}

1. O uso de espaço para registro de respostas no próprio questionário foi uma medida que irá agilizar a tabulação e servirá de referência para o entrevistado diminuindo, portanto, o caso de esquecimentos.

2. É preciso, no entanto, se perguntar o quanto de profundidade é desejada, uma vez que o espaço para o registro é pequeno. Em perguntas onde o entrevistado deve explicar as razöes e motivos de suas respostas, uma primeira tendência dos entrevistados é explicá-las de forma categórica e/ou adjetivadas, por exemplo: "porque é bom; porque eu gosto; porque estou acostumado a fazer assim". Enfim, as respostas são pouco explicativas. Assim, é recomendado que o entrevistador esteja preparado para obter respostas mais substantivas, o que exige uma escuta muito atenta e fazer perguntas de caráter pedagógico para obter respostas mais elucidativas.

3. As alternativas serão lidas ou já são o resultado de um pré- estudo? A depender da resposta, o procedimento do entrevistador será diferente. Se ler as alternativas, deverá fazer de forma pausada, pronto para explicar e responder perguntas de entendimento. Se não for ler, o questionário deverá ter espaço para outras respostas.

4. Evite sempre o emprego de adjetivos no enunciado de perguntas. Adjetivos são expressões de julgamentos, portanto já direcionam as respostas.

5. A seqūência das perguntas é muito importante porque quando o ritmo é fluido, o entrevistado se sente mais confiante e aberto para responder. Uma forma eficaz de conhecer o ritmo da entrevista é aplicar o instrumento com pesquisadores e amigos com quem se tenha uma boa relação de confiança. Nesses momentos ter espírito aberto para criticas e estar fundamentado é essencial, do contrário corre-se o risco de se perder amigos, tempo e confiança em si.

\section{Considerações Especificas:}

Q.1: Na alternativa: "Uma atitude geral da vontade do homem favorável à Deus OU favorável a ética e a moral?

Perguntas com a preposição Ou exigem duplo cuidado no registro, do contrário no momento da tabulação poderá existir a dúvida sobre qual foi exatamente a resposta do entrevistado. O mais recomendado é a divisão da pergunta:

Uma atitude geral da vontade do homem favorável à Deus? 
Uma atitude geral da vontade do homem favorável a ética e a moral?

Q.1.1: Qual é o significado de vários elementos?

Alguns entrevistados podem entender elementos por: rituais, hierarquias, santos, cerimônias, número de participantes, etc. Outros podem entender como palavra ofensiva: elementos é uma palavra com forte conotação policialesca.

o entrevistador tem que estar preparado para obter a resposta que procura.

Q.2: 0 entrevistado vai perguntar cada uma alternativas, ou vai deixar livre para o entrevistado?

Ver item 3 de Considerações Gerais

Q.2.1: São duas perguntas em uma só. É preciso um cuidado e um espaço maior para registrá-las.

Q.2.2: $O$ que significa o uso da palavra incerta no enunciado da questão?

Como o entrevistador entende este adjetivo que é o resultado de um julgamento? Esta pergunta será perguntada, apenas quando o entrevistador decidir?

Q.3: Cada uma das alternativas será lida?

O entrevistado pode ter uma justificativa para cada uma das alternativas, que não são excludentes. Escolher uma única alternativa poderá não ser a melhor estratégia, visto que a experiência de crença é sofisticada e complexa, envolvendo vários significados.

Será importante dar mais espaço para as respostas que irão justificar as alternativas.

Q.4: 0 enunciado nảo está claro, porque se inicia com uma negativa e logo passa para uma afirmativa. $\dot{E}$ como se o entrevistador esteve dizendo que o entrevistado não acredita em Deus mas faz uso dele. Isto pode ser entendido como ofensivo para algumas pessoas. É mais adequado refazer a pergunta.

Está pergunta será feita para todos? Ou apenas para aqueles que não responderem as Questões 3.0 e 3.1 ?

Q.4.1: Enunciado de dificil compreensão (ver acima). É melhor dividir as perguntas:

Para você Deus é um Ser real existente? Sim Não Explique

Para você Deus é um ideal pelo que se vive? Sim Não Explique

Q.4.2: Deixar espaço para as várias respostas: felicidade, moralidade e outros aspectos. Cada uma exige uma especificidade.

Questżes 5, 5.1, 5.2, e 5.3: deveriam ser feitas antes das questões 4 e 4.1. Do contrário, o entrevistado pode ter a sensação de estar sendo testado de forma agressiva. 


\section{APÊNDICE VI - Parecer de Luiza Klein Alonso (continuacão)}

Q.6: São várias perguntas em um só enunciado, o que significa que o entrevistador deve ir perguntando uma de cada vez:

Você reza: $\operatorname{Sim}$ não

Se Sim: Por que?

Você reza:

Puramente por hábito

Por costume social

Porque acredita que Deus ouve suas preces

O registro dessas respostas deve ser bem cuidadoso, especificando cada uma das respostas às perguntas.

- emprego das palavras unilateral ou bilateral exigirá uma explicação do entrevistador para o entrevistado. Na verdade, estas palavras poderiam ser categorias de análise do pesquisador, isto é, resultado da compreensão dos resultados do estudo.

São várias perguntas em um só enunciado, o que significa que o entrevistador deve ir perguntando uma de cada vez:

- Vocé sente que recebe algo de Deus em suas preces? Sim não

Se Sim: Por que?

- Você sente Deus como força? Sim não

Se Sim: Por que?

- Você sente Deus como espírito divino? Sim não

Se Sim: Por que?

- A oração é uma comunhão real entre você e Deus? Sim não

Se Sim: Por que?

Cuidado com o uso da palavra real, ela tem vários sentidos e sinaliza uma resposta.

Q.9: Qual é o sentido da palavra autoridade? O entrevistador deverá explicála. Se as entrevistas forem feitas por apenas um entrevistador, a explicação será uma só, mas se forem vários pesquisadores, estes deverão ser treinados para oferecerem uma única explicação.

Q.9.1: São várias perguntas em um só enunciado, o que significa que o entrevistador deve ir perguntando uma de cada vez:

- Sua fé religiosa é baseada na Bíblia? Sim não

Se Sim: Por que?

- Sua vida é baseada na Bíblia? Sim não

Se Sim: Por que?

- De que modo, sua crença em Deus e sua vida favorável a Ele e aso companheiros humanos seriam afetadas pela perda da fé na autoridade da Biblia?

Esta pergunta será feita apenas para algumas pessoas, e exigirá muito poder de discernimento e decisão do entrevistador porque é o resultado de uma análise das respostas de entrevistado. Seria melhor dividi-la ou então não fazê-la.

Q.10: Estaria melhor logo depois da Q. 7. Viria de forma mais fluida. 


\section{APÊNDICE VII - Material entreque à comissão julgadora sobre a avaliacão do Inventário de crencas religiosas no esporte: segunda fase do processo de construcão do instrumento}

\section{Prezado Avaliador}

Em continuidade ao estudo sobre crenças religiosas no esporte. Eu, Paulo Felix Marcelino Conceição, aluno do curso de Pós-Graduação, nível Mestrado, na Escola de Educação Física e Esporte da Universidade de São Paulo. Apresento o "Inventário de Crenças Religiosas no Esporte" (ICRE). Este instrumento, surge como fruto da colaboração prévia de quatro juizes independentes três psicólogos e um educador, que avaliaram a possibilidade de utilização do "Questionário Pratt de Crenças Religiosas" no esporte. Os quais, fizeram uma série recomendações, que paralelamente, ao aprofundamento da revisão de literatura sobre as obras de J. B. Pratt $(1907,1923)$ e as pesquisas desenvolvidas por Freitas (2002) em tese de doutorado orientada pelo Prof. Dr. Norberto Abreu e Silva Neto na Universidade de Brasília, resultaram no delineamento de um novo instrumento. Para o qual, peço sua valiosa e inestimável colaboração no sentido de emitir um parecer.

O objetivo deste instrumento é buscar o significado, compreender o papel e dimensionar os tipos de crença religiosa no esporte de acordo com Pratt (1923), Freitas (2002) em quatro dimensões:

I- Crença tradicional - Atitude religiosa que é adquirida no passado, sob a influência de figuras de autoridade - pais, professores, igreja e/ou tradição. Teria como principal característica, o fato da pessoa não questionar os conteúdos religiosos primitivos, os quais, se manteriam na vida adulta como que por inércia, ou porque simplesmente a pessoa se acostumou a agir conforme determinados costumes.

II- Crença intelectual - Atitude religiosa que surgiria após sucessivas frustrações da crença primitiva. Apresenta-se como um rompimento com as figuras de autoridade tradicionais. Seria um tipo particular de crença religiosa que se guiaria única e exclusivamente pela razão, baseada em fatos e na experiência verificável. 


\section{APÊNDICE VII - Material entreque para a comissão julgadora sobre a avaliacão do Inventário de crenças religiosas no esporte (continuacão)}

III- Crença emocional - Atitude religiosa que se apoiaria na experiência vital, apresentandose com vivências de fundo emocional. Uma atitude religiosa que se traduz em um sentimento de conexão com Deus. Segundo Pratt (1907) a crença emocional pode ser verificado com maior intensidade no discurso e nas atitudes das pessoas tidas como místicas ao longo da história.

IV- Crença moral - Seria o tipo de atitude religiosa que se apóia em tudo aquilo que poderia ser considerado como: a coisa certa, o que é correto ou deveria ser feito, e não necessariamente no que deve ser acreditado ou sentido. Seria uma atitude religiosa marcada pelo ativismo, apoiada em valores morais. 


\section{APÊNDICE VII - Material entreque para a comissão julgadora sobre a avaliacão do Inventário de crenças religiosas no esporte (continuacão)}

INVENTÁRIO DE CRENÇAS RELIOSAS NO ESPORTE.

\begin{tabular}{|c|c|c|c|c|}
\hline Equipe: & & Data: & & \\
\hline Modalidade: & Posição: & \multicolumn{3}{|c|}{$\begin{array}{l}\text { Sexo: } \\
\text { Masculino } \square \text { Feminino } \square\end{array}$} \\
\hline $\begin{array}{l}\text { Você Acredita em Deus? } \\
\operatorname{sim} \square \quad \text { não } \square\end{array}$ & \multicolumn{4}{|l|}{ Religião: } \\
\hline \multicolumn{2}{|l|}{ Local de nascimento: } & \multicolumn{3}{|c|}{ Data de nasc.: $\quad / \quad$ l } \\
\hline $\begin{array}{l}\text { Você estuda Atualmente: } \\
\operatorname{sim} \square \quad \text { não } \square\end{array}$ & \multicolumn{2}{|c|}{ Qual o seu grau de escolaridade: } & \multicolumn{2}{|c|}{$1^{\circ} \mathrm{Grau} \square \quad 2^{\circ}$. Grau $\square \quad$ 3.0 Grau $\square$} \\
\hline
\end{tabular}

A seguir, você encontrara algumas questões sobre crenças religiosas, procure responde-las de forma ampla, completa e refletidamente. Caso o espaço destinado à resposta não seja suficiente. Por favor utilize o espaço pautado no verso das folhas - Obrigado. 


\section{APÊNDICE VII - Material entreque para a comissão julgadora sobre a avaliacão do Inventário de crenças religiosas no esporte (continuacão) INVENTÁRIO DE CRENÇAS RELIOSAS NO ESPORTE}

Questles adaptadas de Pratt (1907), Abreu e Silva (1998), Freitas (2002) - "Questionário Pratt Sobre Crencas Religiosas".

1. Escolha uma ou mais alternativas, de acordo com aquilo que você nomalmente pensa sobre religiåo. Apenas, tome o cuidado de justificar cada uma das suas respostas.

$O$ que a religiäo significa para vocé pessoalmente? $\mathrm{E}$...

$\square$ Uma crença de que algo existe? Descreva com é esta crença:

$\square$ Vivenciar, sentir e/ou experienciar a presença de Deus? Como é esta experiência:

$\square$ Uma atitude do homem para difundir a idéia de Deus e as coisas que são corretas ? Explique:

$\square$ Respeitar as tradições e obedecer às figuras de autoridade? Quais:

$\square$ Outro significado? Explique:

Complete a sua a resposta:

2. Escolha uma ou mais alternativas, de acordo com aquilo que você normalmente pensa sobre Deus Apenas, tome o cuidado de justificar as suas respostas.

Por que você acredita em Deus? É ...

$\square$ Com base em algum fato, prova ou argumento? Se for, explique como e qual (is):

$\square$ Porque você já experimentou ou sentiu SUA presença? Descreva como foi esta experiência:

$\square$ Com base na autoridade de um livro sagrado, ou de alguma pessoa? Se for, qual (is):

$\square$ Porque ele significa o agir corretamente, ter e divulgar valores morais ? Explique:

$\square$ Outro motivo? Explique:

Complete a sua a resposta: 
APÊNDICE VII - Material entregue para a comissão julgadora sobre a avaliacão do Inventário de crenças religiosas no esporte (continuacão)

3. Deus é algo real para você, tão real como um amigo terreno, embora diferente? sim $\square$ nảo $\square$. Explique:

4. Você sente que já experimentou a presença de Deus ? sim $\square$ não $\square$. Se sim, descreva o que você quer dizer com "experimentar Sua presença". Explique:

Se você não teve esta experiência, você aceita o testemunho de outros que dizem ter sentido a presença de Deus? Por favor, responda esta questão com cuidado e o máximo possivel de detalhes:

5. Você acredita que Deus poderia ajudar a vencer obstáculos no esporte? $\operatorname{sim} \square$ não Explique:

6. Deus seria um suporte emocional para o atleta ? sim $\square$ não $\square$. Como é para você ? 
APÊNDICE VII - Material entregue para a comissão julgadora sobre a avaliacão do Inventário de crenças religiosas no esporte (continuacão)

7. Vocè reza para obter a vitória nas competições esportivas? sim $\square$ não $\square$. Por que?
pessoas? sim $\square$ não $\square$. Explique:
Você acredita que o esporte seria uma forma de louvar Deus e levar sua palavra a outras

9. Se você tivesse que se tornar inteiramente convencido de que Deus não existe, isto faria uma grande diferença em sua vida - Seja com relação à felicidade, moralidade, ou a carreira esportiva ? Explique como seria afetada cada uma destas esferas:

Com relação à felicidade -

- Com relação à moralidade

- Com relação à carreira esportiva:

10 Você se considera uma pessoa supersticiosa? sim $\square$ não $\square$. Por que? 
APÊNDICE VIII - Avaliação da comissăo julgadora do Inventário de crencas religiosas no esporte: segunda fase do processo de construção do instrumento

Na segunda fase de construção do inventário Pratt de crenças religiosas no esporte, os itens considerados confusos, agressivos ou ofensivos pelos juizes na primeira fase de validação do instrumento, foram eliminados e neste processo inseridas questões sobre aspectos relativos à pesquisa sistemática da crença ético-moral.

Implementadas estas modificações, o instrumento sob a denominaçăo Inventário de crenças religiosas no esporte (ANEXO IV), foi novamente submetido à avaliação de três juízes especialistas:

- Luiza Klein Alonso

- Luiz Fernando Bacchereti

- Marta Helena de Freitas

Os pareceres dos juizes na segunda fase de avaliação do Inventário Pratt de crenças religiosas no esporte encontram-se respectivamente nas seguintes paginas: 136,138 , e 140. 
136

APÊNDICE IX - Parecer de Luiza Klein Alonso

Parecer

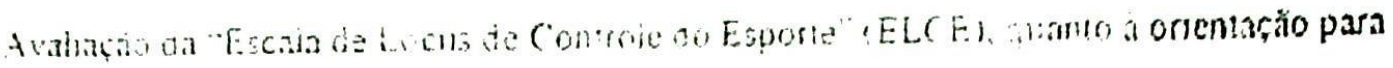
evemahdade e merrahiade on componamento gerat dos atiens.

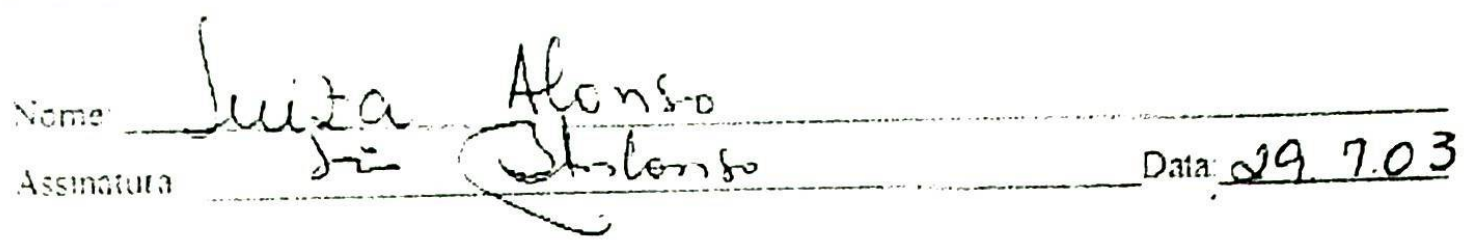

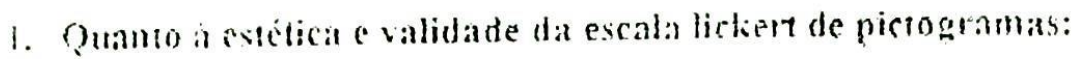

Concordo $\square$ Discordo $\square$ Sugestos: as modificafos ficaram muito taoas duixanao o instrumento + daro l. eficierte.

2. Quanto ao comendo e oriemasão para lócus de controle intemo dos iteris: 01. 04,05.

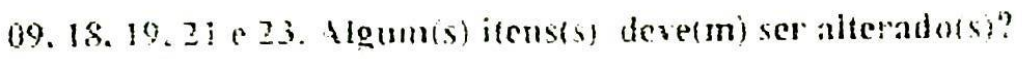

Concordo $\square$ Discordo $\square$ Emqual(s)sentido(s)" Os itens 01 e 21 poucidam di altercepo ws ikm 1 acuscentar a puipofricteor "dos", antifo "uma". ino item21 pubtrais o 
137

APÊNDICE IX - Parecer de Luiza Klein Alonso (continuação)

3. Quanto a contcudo c orientaçio para lócus de controle externo pelo acaso, dos

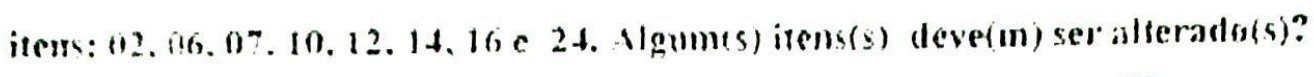

Concordo $\square$ Discondo $\bigotimes$ Emqual(s) sentido(s)" Estef berm clavos

4. Quanio ao conterido e orientação para lócus de controle extemo por pessoas poderosas, dos itens : 03. 08, 11, 13, 15, 17. 20 e 22. Algum(s) itens(s) deveim) ser alleradeist?

Concordo $\square$ Discordo $\triangle$ Em qual(s) sentido(s)? Gostä́ colecntes e bern articuledos. 
138

APÊNDICE X - Parecer de Luiz Fernando Bacchereti

Parecer

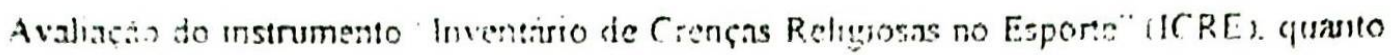
no dinensionameygo, upo ejignuficado das cret cas religrosas no esporte

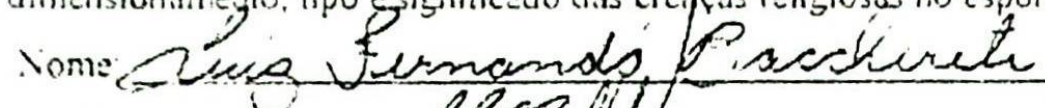
issinatira:

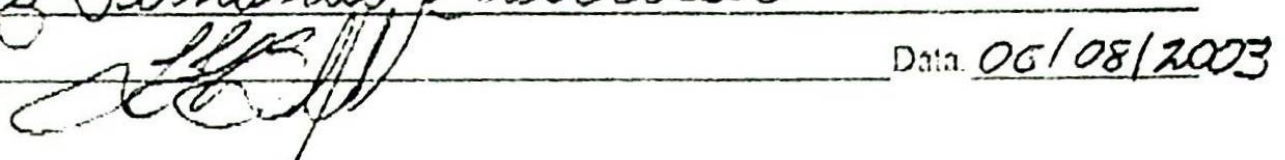

1. Quanto ao titulo, nuência y rhal, seqüência das questões, estética do instrumento e esparos para registron das respostas:

Concordo $\varnothing$ Discordo $\square$ Sugestǒes:

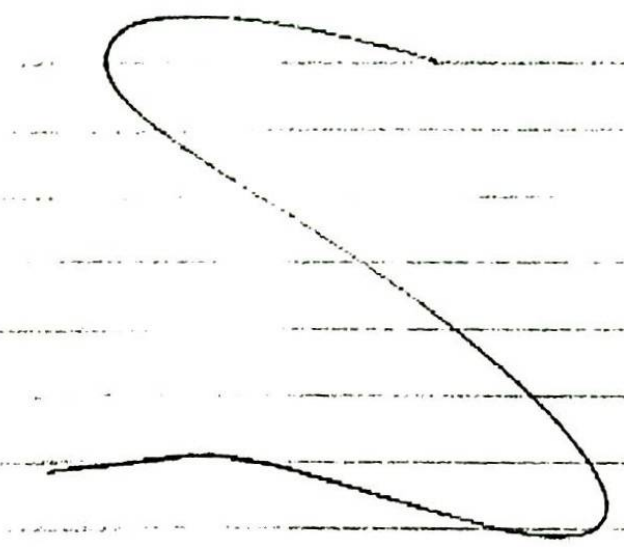

2. Quanto a conteudo e orientaça para as dimensōes de fé religiosal conchuidas por Pratt (1923) . Algum(s) itens(s) deve(m) ser alterado(s)?

Concordo $\square$ Discordo $\square$ Em qual(s) sentido(s) (1) Talue definir melthos o

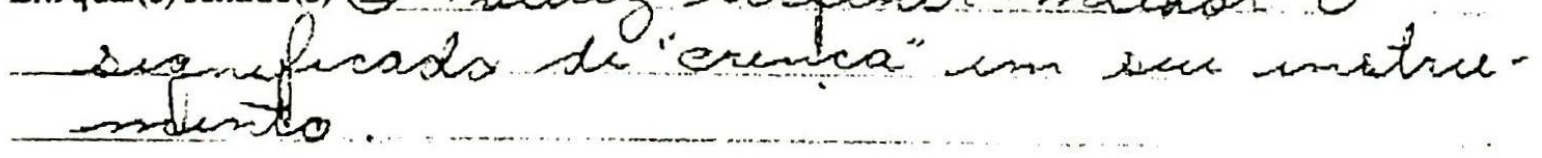

(1) cuncas mellar puntsis silativar pois o individus/sufitis fode utar. intolidido corm as delas cateparias on náo duaser una inflincer a ates (crence $x$ sepaticasi) 
139

APÊNDICE X - Parecer de Luiz Fernando Bacchereti (continuacão)

3. Quanto ao conteúdo, validade e propriedade das questőes específicas sobre retigizło e esporte. Algum(s) item(s) deve(m) ser alterado(s)?

Concordo $\square$ Discordo $\square$ Em qual(s) sentido(s)?: Tara a prestaí ads Validade a muma scuria sotar fandamentada atrausis de dados represtentatesos da omastra ntiligada pulo antar do sistruments.

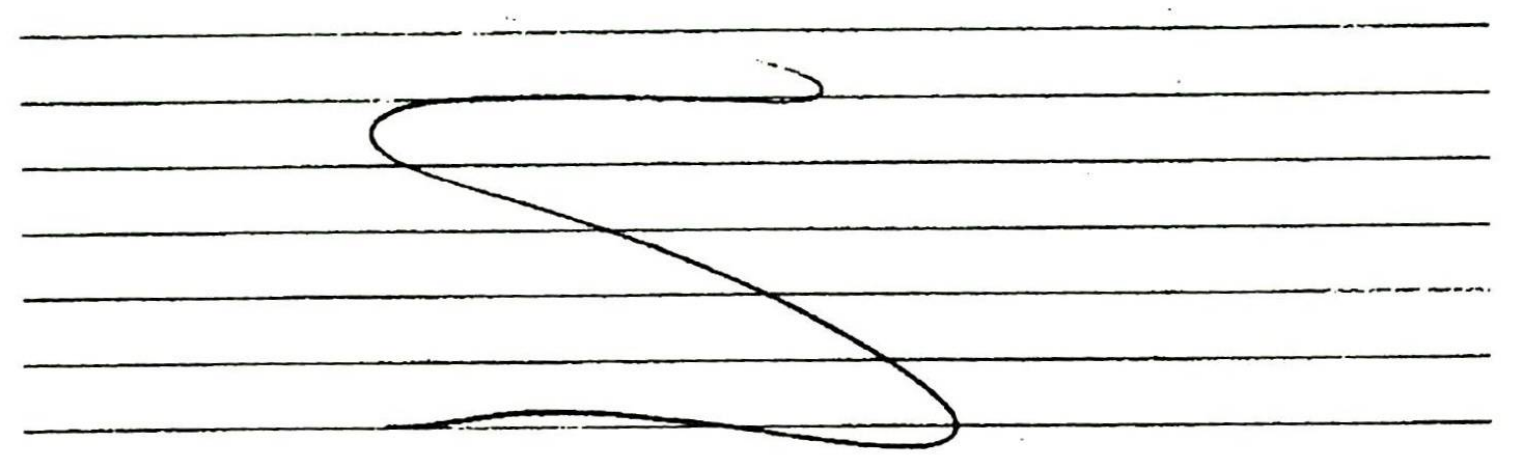

4. Outras sugestros e comentários: Vide aleserusacoés fictas no protacola. 


\title{
APÊNDICE XI - Parecer Marta Helena de Freitas
}

Página 1 de 2

\section{Paulo Félix}

\author{
De: $\quad$ "Marta Helena de Freitas" <mhelena@ucb.br \\ Para: $\quad$ Paulo Fétix" <paula-felix@uol.com.br \\ Cc: <mhelena@pos.ucb.br \\ Enviada em: quinta-feira, 10 de jultho de 2003 17:50 \\ Assunto: Re:
}

Prezado Paulo.

Recebi e li o seu material, que julguei muito interessante e bastante pertinente. Agradeço-the pelas citaçes de meu babalho. Penso que fez muito bem e deixar os espaços para os comentários e detalhamento das respostas. De fato, esta foi uma sugestao que recebi tambem tanto dos juizes quanto dos estudantes. quando de minha pesquisa.

Juguei os comandos claros e pertinemtes. E isso vocé poderá. depois, conferir numa pesquisa piloto junto aos proprios sujeitos de suas pesquisa, os desportistas.

Achei legal que voce resumiu antes as modalidades de crenças para situar os juizes, isso facilita para nos orientarmos. E voce relacionou tambem a última modalidade de crença descrita por Pratt, a qual náo pude explorar em meu trabalho, em funça do tempo já curto para a defesa quando. finaimente. obtive o tivro publicado em 1921.

Minhas sugestరes, que aponto a seguir, devem ser contextualizadas conforme os seus objetivos mais especificos. Portanto, veja se elas se aplicam ou nảo ao que vocé pretende, ok?

Eu acho aquela idéia do USO que se pode fazer de Deus, que o Questionário original explora em uma das questbes.

bastante pertinente. pois ajudaria a avaliar melhor duas modalidades de crença: a primitiva e a moral. Penso que a questáo 5. do seu inventário, explora um pouco isso, mas refere-se especificamente à vitoria. Nâo seria pertinente tamberm uma questáo pertinente à derrota? Ou seja, estou me referindo ao fato de se recorrer a Deus para lidar com a derrota (seja atribuindo-the algum sentido, ou aceitando-a, ou outra coisa.). Penso, por exemplo, no papel da oraçăo também para buscar consolo, e náo so para fazer pedidos, por exemplo. Eu acho que uma queståo assim permitiria avaliar os valores envolvidos na atitude religiosa, ou sobre os quais esta se apoia. Tais valores podem ser de cunho mais utilitarista (por exemplo, rezar para solicitar a vitoria); ou de cunho mais existencial (por exemplo, orar para encontrar sentido na derrota).

A questáo da crença primitiva tamberm ficaria explorada aqui, pois explicaçes do tipo "foi porque Deus quis". ancora-se numa autoridade previamente dada. à qual se delega a responsabifidade de uma vitoria ou de uma derrota, por exemplo. Tamberm a descrença nos moldes intelectuais pode se sustentar sobre uma modalidade contrária a essa, por exemplo, quando o

desportista se revoltaria contra possive is injustiças que costumam ocorrer em competiços e usa isso para questionar a existência real de Deus.

Quanto às questoes que voce relaciona ao final, para os juizes. respondo-as a seguir:

Penso que o INCRE está bem elaborado quanto ao dimensionamento, ao tipo e aos significados das crenças religiosas, ressalvando as questóes apontadas acima. Mais uma ressalva quanto à última questáo. Fiquei me perguntando sobre qual a relaça estabelecida entre superstiço e crença refigiosa. Imagino que a superstiço está mais para crença primitiva, certo? Seria esse o objetivo da questâo?

1. Penso que o titulo do instrumento está bem posto, há fluencia verbal, a sequencia pertinente, e o espaço para a resposta tambem.

2. Penso que, conforme os seus objetivos mais especificos, talvez fosse pertinente o acréscimo da questáo relativa ao modo de lidar com a derrota e respectivo papel da crença em Deus e da oraça.

3. Minha dúvida fica em relaça à última queståo, conforme explicitei anteriormente. Senti falla de uma queståo que investiga o que é Deus, para o desportista, ou o que ele quer dizer quando utilizada essa palavra. Se fosse o caso de acresconta-la, penso que deveria estar em segundo hugar, logo apos a pergunta sobre a religiâo. Penso que a forma como a pessoa define Deus é muito importante para avaliarmos a modalidade de crença sobre a qual essa definicho de sustonta. Peto menos foi isso que pude apreender em minha pesquisa.

4. Veja que minhas sugestóes vảo no sentido de detalhar mais as questóes. Isso năo significa necessariamente aumentar o números das questoes globais; voce pode avaliar se é methor acrescentar ou aglutinar essas questóes em outras já existentes. O Pratt fez isso em várias delas. Além disso. é preciso avaliar se minhas sugestoes fazem sentido pra voce, considerando-se os objetivos de sua pesquisa.

$E$. mais. prabenizo the peto trabalho e agradeç-the a confiança pela consulta. Se puder ser útil outras vezes, conte comigo. Estarei viajando nos próximo dias, mas a partir de meados de agosto estarei por aqui novamente.

Um grande abraço.

Marta Helena

- Original Message -.

From: Paulo Félix

To: mhelenasucb.br

Cc: mhelena@pos. $4 \mathrm{cb} . \mathrm{br}$

Sent: Wednesday. July 09, 2003 10:17 AM

Prezada Marta Helena, 


\title{
APÊNDICE XI - Parecer Marta Helena de Freitas(continuação)
}

\author{
Estou enviando em anexo o Inventánio de Crenças retigiosas no Esporte para sua avaliaço conforme combinamos. \\ Um grande abraço. \\ Paulo Fellox. \\ Obs. O endereço do site de busca de Ivros raros, pelo qual encontrel os livros do Pratt é este :www.abebooks.com .
}




\section{APÊNDICE XII - Comunicação pessoal com Ralph McKenna}

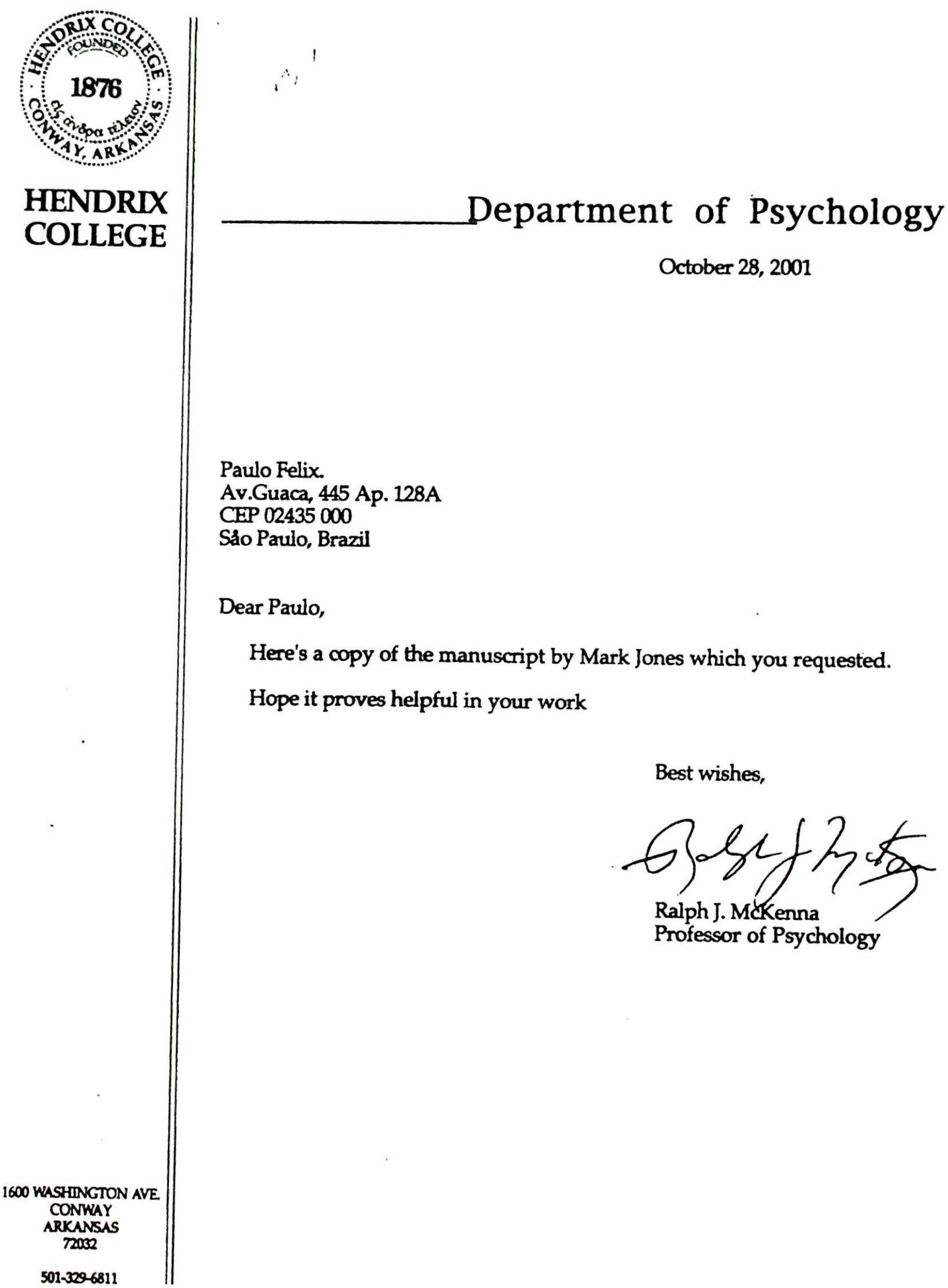


APÊNDICE XIII - Escala de lócus de controle de Rotter (original)

Locus of Contro

1) a. Chlldren get into trouble because their parents punish them too much.

b. The trouble with nost children nowadays is that thelr parents are too easy with tinem.

2) a. Many of the unhapoy things in people's lives are partly due to bad luck.

b. People's misfortines result. from the mistakes they arke.

a. One of the major reasons why we have wars is because people don't take enough interest in politics.

b. There will always be wars, no watter how hard people try to prevent them.

4) a. In the long run people get the respect they deserve in this world.

b. Unfortunately, an incividual's worth cften passes unrecognized no matter how hard he tries.

5) a. The ldea that teachers are unfair to students is nonsense.

b. Most students don't reallze the extent to which thelr grades are influenced by accidental happentags.

6) a. Without the right breaks one cannot be an effective leader.

b. Capable people who rall to becóme leaders have not taken adrantage of their opportunities.

7) a. No matter how hard you try some people just don't like you.

$b$. Feople who can't get others to like them don't understand how to get along with others.

8). a. Heredity plays the major role in determining one's personality.

b. It is one's experiences in life which determine what they're like.

9) a. I hare often found that what is going to bappen wiII happer.

b. Trusting to fate has never traned out as well for me as making a decision to take a definite course of action.

10) a. In the case of the weII prepared student there is rarely if ever such a thing as an unfalr test.

b. Many. tives exam questions tend to be so unrelated to course work that studying is really useless.

12) a. Becoming a success is a matter of hard work, luck bas little or nothing to do with it.

b. Getting a good job depends mainity on belng in the right place at the right time.

12) a. The arerage cltizen can have an lafluence in government decislons.

b. This world is rwn by the rew people in power, and there is not much the l1ttle guy can do about $1 t$. 
APÊNDICE XIII - Escala de lócus de controle de Rotter original (continuaçăo)

Loas of Control 17

13) a. When I make plans, I am.almost certaln that I can make them rork.

b. It is not alwajs wise to plen too rar anead because many thlngs turn out to be a matter of good or bad cortune anyhow.

14) a. There are certain people kho are just no good.

b. There is some good in everyoody.

15) 2. In wr case getting what I want has 1lttle or nothing to. do with luck.

b. Many tines we might just as rell decide what to do by rlipplang a coln.

16) a. Who gets to be the boss of ten depends on who was lucky enough to be in the right place first.

b. Getting people to do the right talng depends upon ability, luek has little or nothing to do with $1 t$.

17) a. As far as world affalrs are concerned, most of us are the rictims of forces we can nelther understand, ror control.

b. By taking an active part in political and social affairs the people can control world events.

18) a. Sost people don't reallze the extent to which thelr lives are controlled by accilental happenings.

b. There really is no such thing:as "luck".

19) a. One should always be willing to admit mistakes.

b. It is usially best to cover up one's raistakes.

20) a.It is hard to know whether or not a person really likes you. b.How many. friends you have depends upon how nice a person you are.

21) a. In the long run the bad things that happen to us are balanced by the good ones.

b. Most misfortunes are the result of lack of ablilty, ignorance, laziness, or all three.

22) a. Yith enough effort we can w1pe out political corruption.

b. It is difflcult for people to have much control orer the thitags politicians do in office.

23) a. Sometimes I can't understand how teachers arrive at the grades they give.

b. There is a direct connection between how hard I study and the grades I get.

24) a. A good leader expects people to decide for themselves what they should do.

b. A good leader makes it clear to everybody what their jobs are.

25) a. Mans times I feel that I hare little influence orer the thlngs that happen to me.

b. It is lmpossible for me to belleve that chance or luck plers an important role in my life. 
APÊNDICE XIII - Escala de lócus de controle de Rotter original (continuação)

Locus of Control $1 \varepsilon$

26)

a. People are lonely because they don't try to be friendly.

b. There's not much use in trylng they like you, they like you.
if. the

27) There is too much emphasis on athletics in high schoo
b. Team sports are an excellent way to bulld character.

28) a. What happens to me is my own dolng.

a. What happens to me is my orn dolng. direction my life is taking.

29) a. Most of the time I can't understand why politiclans behave the way they do.

b. In the long run the ceople are responsible for bad government on a natlonal as well as on a local level. 


\title{
APÊNDICE XIV - Material entreque à comissão julgadora sobre a avaliacão da escala multidimensional de lócus de controle do esporte: primeira fase de construcão do instrumento
}

\author{
UNIVERSIDADE SÃO PAULO \\ Escola de Ecucaçăo Física e Esporte \\ Pós-graduaça
}

\section{ESCALA DE LÓCUS DE CONTROLE}

A seguir você encontrará 25 itens da "Escala de b́cus de Controle" (ELC). Este instrumento foi criado por Rotter (1966) e traduzido no Brasil por Dela Coleta (1979) em um estudo onde sugeriu algumas modificaçoes que agora estão sendo implememtadas por Paulo Félix Marcejino Conceiçåo - aluno do curso de Pós-Graduaçåo - Nível Mestrado - na Escoila de Educaçăo Física e Esporte da Universidade de Săo Paub, com o intento de validar a escala de bocus de controle no cenário do esporte.

O objetivo deste instrumento é dimensionar o constructo lócus de controle em interno e/ou externo, descrevendo-se uma série de situaģóes hipotéticas onde o sujeito é forçado a optar por uma proposição entre duas, em uma das quais se refletiria a orientaça para a internalidade $e$ na outra s externalidade.

O conceito de lócus de controle originou-se da teoria da aprendizagem social, é defínido como uma característica psicológica que tipifica o grau em que o sujeito percebe os acontecimentos do dia a dia como sendo consequèncias de suas próprias apoes ou do poder de influéncia de terceiros - lócus de controle intemo ou lócus de controle externo.

Pessoas com lócus de controle interno tenderiam a adotar suas conviccóes pessoais como um sistema referencial para as suas decisões. E como consequêtencia deste posicionamento, estariam mais inclinadas em perceber os acomtecimentos do dia a dia como sendo resultantes de suas próprias aç̃es.

Pessoas com lócus de controle externo tenderiam a usar como referencial para suas tomadas de decisð̃es elementos exteriores, em um movimento dinâmico onde os acontecimentos que thes sucedem seriam justificados como frutos do poder de influência de terceiros - pessoas poderosas, figuras de autoridade, destino, sorte ou acaso. N\$o admitindo os acontecimentos do dia a dia como consequéncias dos seus comportamentos.

Segundo Pais Ribeiro (1994) cada vez que se utiliza um instrumento de personalidado é necessário que este seja colocado em questio. Considerando-se que erto escala deverd ser eplicada em populacotes de atletas, a clareza o a simplicidado da linguagem assumem uma particular importincia. 


\section{APÊNDICE XV - Comissão julgadora da escala multidimensional de lócus de controle do esporte: primeira fase de construcão do processo de construcão do instrumento}

Na primeira fase de construção da escala multidimensional de lócus de controle, foram feitas algumas modificaçōes no instrumento original de J. B. Rotter, objetivando atualizar a linguagem e implementar as sugestões feitas por J. A. DELA COLETA (1979) na tradução desse instrumento para o português.

Três juizes avaliaram o instrumento na primeira fase:

- Sonia Maria da Silva

- Luiz Femando Bacchereti

- Luiza Klein Alonso

Os pareceres dos juizes encontram-se a seguir nas paginas: 148, 155, 162. 


\section{APÊNDICE XVI - Parecer de Sonia Maria da Silva}

\begin{tabular}{|c|c|c|c|}
\hline \multirow[t]{2}{*}{ 1- } & ㅁ & \multicolumn{2}{|l|}{ Muitos dos infortúnios na vida das pessoas são em parte devido à mh sorte. } \\
\hline & $\square$ & Os infortunios das pessoas resultam dos erros que elas cometem. & \\
\hline & & Sim & Năo \\
\hline \multicolumn{4}{|c|}{ A) Os termos sảo simples e claros? } \\
\hline \multicolumn{4}{|c|}{ B) A primeira opcão reflete a orientação para lócus de controle excerno? } \\
\hline \multicolumn{4}{|c|}{ C) A segunda opcăo reflete a orientacào para lócus de controle interno? } \\
\hline \multicolumn{4}{|c|}{ D) De acordo com sua avaliação esta questão poderia ser melhorada? Como? } \\
\hline \multicolumn{4}{|c|}{ if ares } \\
\hline & $\bar{\square}$ & \multicolumn{2}{|l|}{$\begin{array}{l}\text { Um dos motivos principais pelo qual temos guerras é por que as pessoas não tềm } \\
\text { interesse suficiente por politica. }\end{array}$} \\
\hline & $\overline{\bar{D}}$ & Sempre haverá guerras. Nảo importa o quanto às pessoas tentem impedi-las. & \\
\hline
\end{tabular}

A) Os termos sio simples e claros?

B) A primeira opsĩo reflete a orientafão para lócus de controle interno?

C) A segunda opcão reflete a orientacão para lócus de controle cxterno?

D) De acordo com sua avaliação esta questão poderia ser melhorada? Como ?

$0 \mathrm{~K}$

\begin{tabular}{ll}
\hline $3-$ & Mais cedo ou mais tarde, as pessoas acabam oblendo o respeito que merecem \\
\hline$\square$ & $\begin{array}{l}\text { Infelizmente, o valor de um individuo passa muitas vezes sem ser reconhecido, não } \\
\text { importando o quanto ele se esforce. }\end{array}$
\end{tabular}

A) Os termos sĩo simples c claros?

B) A primeira opcāo reflete a orientaçâo para lócus de controle interno?

C) A segunda opcão reflete a orientação para lócus de controle exlerno?

D) De acordo com sua avaliação esta questāo poderia ser melhorada? Como?

ox

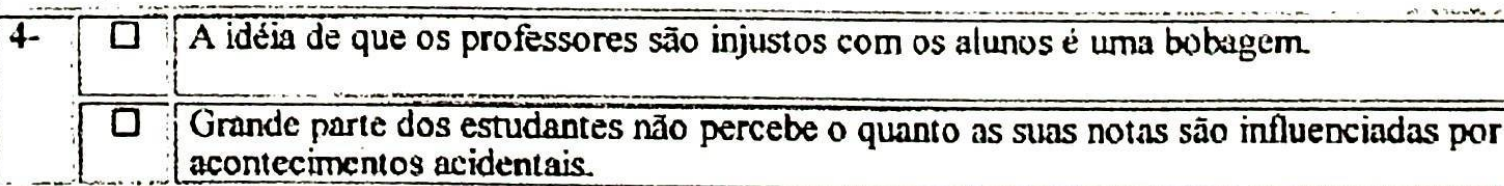

A) Os termos sajo simples e claros?

B) A primeira opcão reflete a orientacão para lócus de controle interno?

C) A segunda opfão reflete a orientacão para lócus de controle externo?

D) De acordo com sua avaliacão esta questão poderia ser melhorada? Como?

i) 


\section{APÊNDICE XVI - Parecer de Sonia Maria da Silva (continuação)}

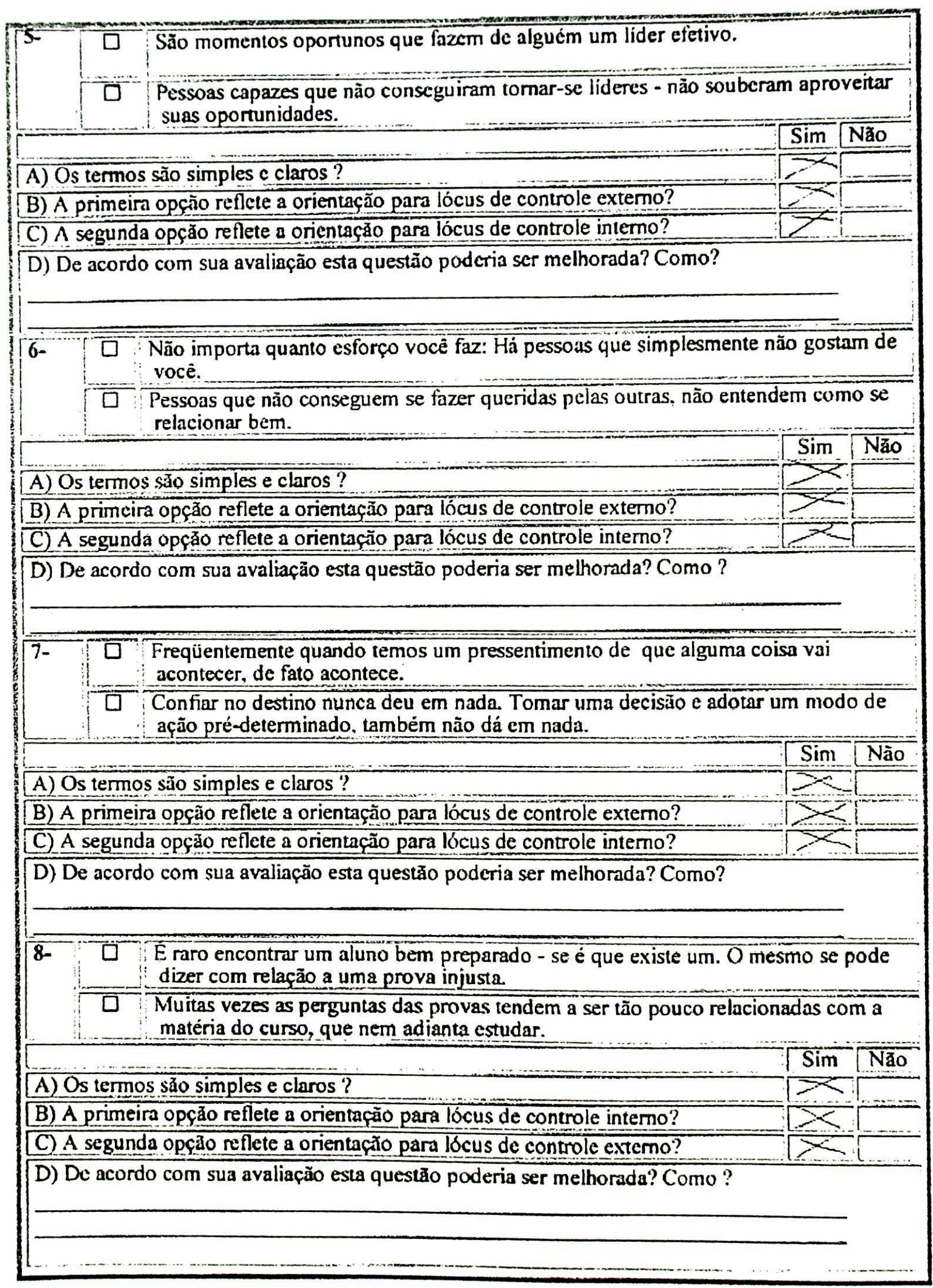




\section{APÊNDICE XVI - Parecer de Sonia Maria da Silva (continuacăo)}

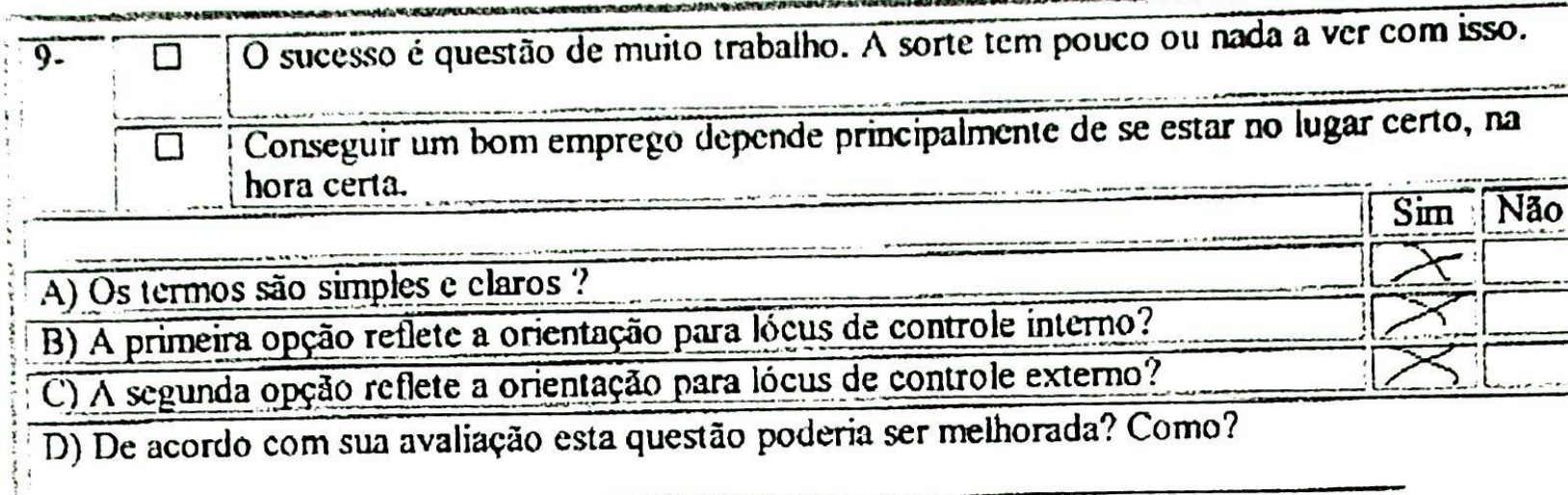

10- $\square$ Q cidadão comum pode exercer uma certa influência nas decisðes do governo. $\square$ Este mundo é governado pelos poucos que estão no poder, e um cidadáo qualquer não pode fazer nada a respeito disso.

A) Os termos são simples e claros?

B) A primeira opção reflete a orientaçăo para lócus de controle interno?

C) A segunda opcão reflete a orientagão para locus de controle externo?

D) De acordo com sua avaliação esta queståo poderia ser melhorada? Como ?

\begin{tabular}{c|c|}
\hline $11-$ & Quando fazemos planos. quase sempre estamos certos de que podemos executá-los. \\
\hline$\square$ & $\begin{array}{l}\text { Nem sempre é prudente planejar com muita antecedência, porque muitas coisas } \\
\text { acabam sendo, de uma maneira ou de outra - uma questão de boa ou má sorte. }\end{array}$
\end{tabular}

A) Os termos são simples e claros?

B) A primeira opsão reflete a orientacão para lócus de controle interno?

C) A segunda opcão reflete a orientação para lócus de controle externo?

D) De acordo com sua avaliação esta questão poderia ser melhorada? Como?

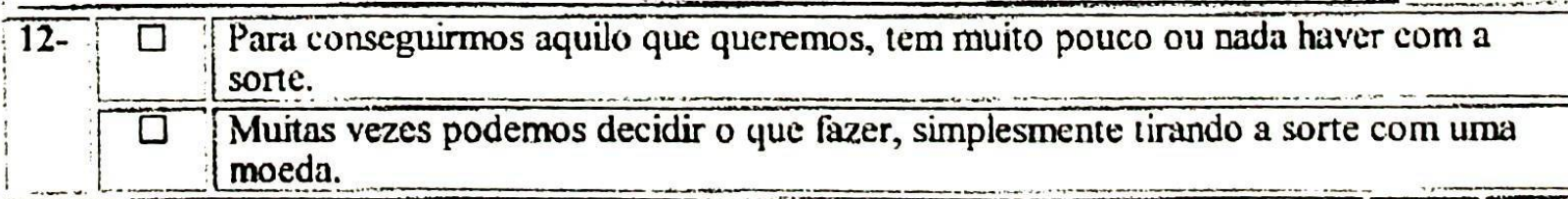
A) Os

A) Os termos sio simples e claros?

B) A primeira opcão reflete a orientação para lócus de controle interno?

C) A segunda opcão reflete a orientação para lócus de controle externo?

D) De acordo com sua avaliação esta questão poderia ser melhorada? Como ?

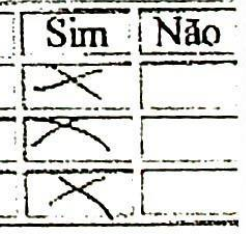
(1) 


\section{APÊNDICE XVI - Parecer de Sonia Maria da Silva (continuação)}






\section{APÊNDICE XVI - Parecer de Sonia Maria da Silva (continuação)}

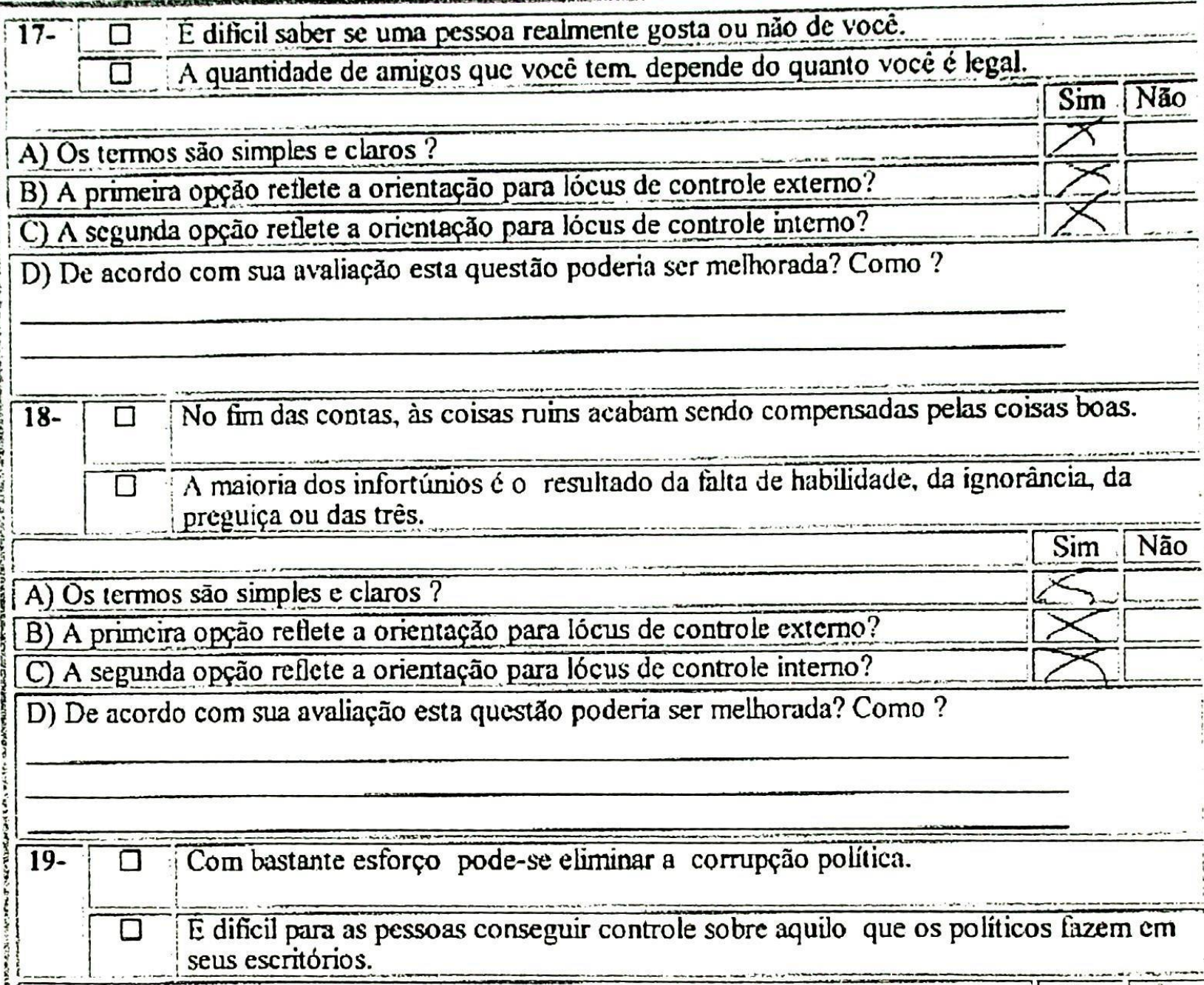

A) Os termos são simples e claros?

B) A primeira opfão reflete a orientacão para lócus de controke interno?

C) A segunda opcão reflete a orientação para lócus de controle externo?

D) De acordo com sun avaliação esta questão poderia ser melhorada? Como ?

20- $\square$ As vezes, não dá para entender como os professores chegam as notas que dão. D Há uma ligação direta entre o quanto se estuda e as notas que se tira.

A) Os termos såo simples e claros?

B) A primeira opyảo reflete a orientação para lócus de controle externo?

C) A segunda opfão retlete a orientaçao para lócus de controle intemo?

D) De acordo com sua avaliação esta questão poderin ser melhorada? Como?

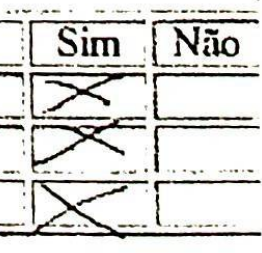




\section{APÊNDICE XVI - Parecer de Sonia Maria da Silva (continuacão)}

\begin{tabular}{l} 
21- U Um bom lider espera que as pessoas decidam por elas mesmas, o que devem fazer. \\
\hline Um bom líder deixa claro para todos quais são as suas tarefas. \\
A) Os termos são simples e claros? \\
B) A primeira opcão retlete a orientação para lócus de controle externo? \\
C) A segunda opfão reflete a orientação para lócus de controle interno? \\
D) De acordo com sua avaliação esta questão poderia ser melhorada? Como?
\end{tabular}

22- Muitas vezes, acreditamos que temos pouca influência sobre as coisas que nos acontecem.

E impossivel acreditarmos que $o$ acaso ou a sorte tenham um papel importante em nossas vidas.

A) Os termos são simples e claros?

B) A primeira opfão reflete a orientação para lócus de controle externo?

C) A segunda opcáo reflete a oricntaça para lócus de controle interno?

D) De acordo com sua avaliação esta questão poderia ser melhorada? Como ?

23- $\square$ As pessoas são solitárias porque nảo procuram ser amigávéis.

Dăo adianta se esforçar muito para agradar as pessoas - se elas gostam de você, é porque simplesmente gostam de você.

A) Os termos são simples e claros?

B) A primeira opcão reflete a orientaçāo para lócus de controle interno?

C) A segunda opcáo reflete a orientaçăo para lócus de controle externo?

D) De acordo com sua avaliação esta questăo poderia ser melhorada? Como ?

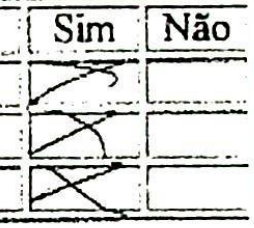
(1)

24 D Aquilo que nos acontece é o resultado de nossas próprias ações.

As vezes, parece que temos pouco controle sobre os rumos que nossas vidas estão tomando.

A) Os termos são simples e claros?

B) A primeira opcáo retlete a urientaçào para lócus de controle interno?

C) A segunda opção reflete a orientação para lócus de controle externo?

D) De acordo com sua avaliação esta questáo poderia ser melhorada? Como ?

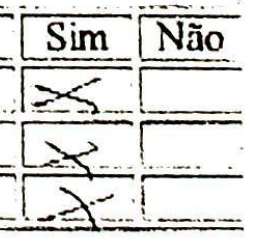




\section{APÊNDICE XVI - Parecer de Sonia Maria da Silva (continuacão)}

25- $\square$ Na maioria das vezes, nāo dá para entender porque os políticos se comportam desta ou daquela forma.

No tinal, as pessoas é que são responsáveis pelos maus governos, tanto em nível nacional quanto local.

A) Os termos são simples e claros?

B) A primeira opcáo reflete a orientação para lócus de controle externo?

C) A scgunda opçăo refletc a orientação para lócus de controle interno?

D) De acordo com sua avaliação esta questão poderia ser melhorada? Como ?

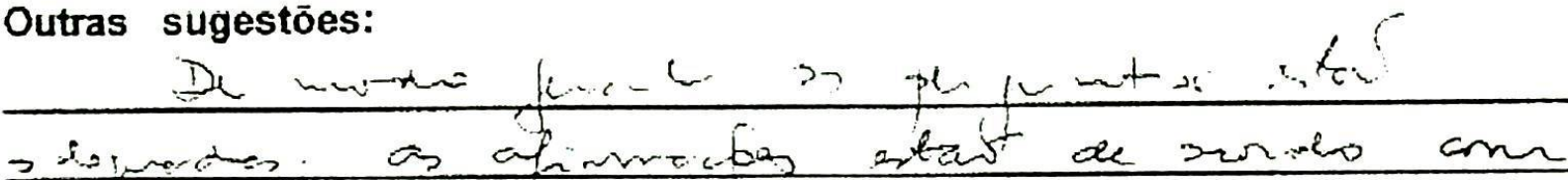

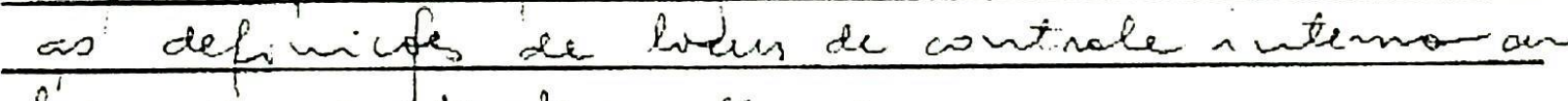

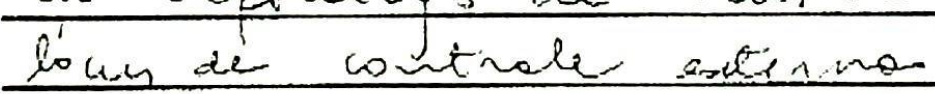

\section{DADOS DO AVALIADOR}

Nome: Sronia mana ta Silve

Assinatura:_ Douriacerave Data: $24 \% 8 \% 3$

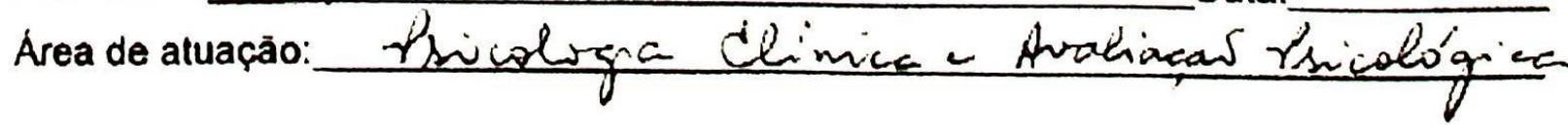




\section{APÊNDICE XVII - Parecer de Luiz Fernando Bacchareti}

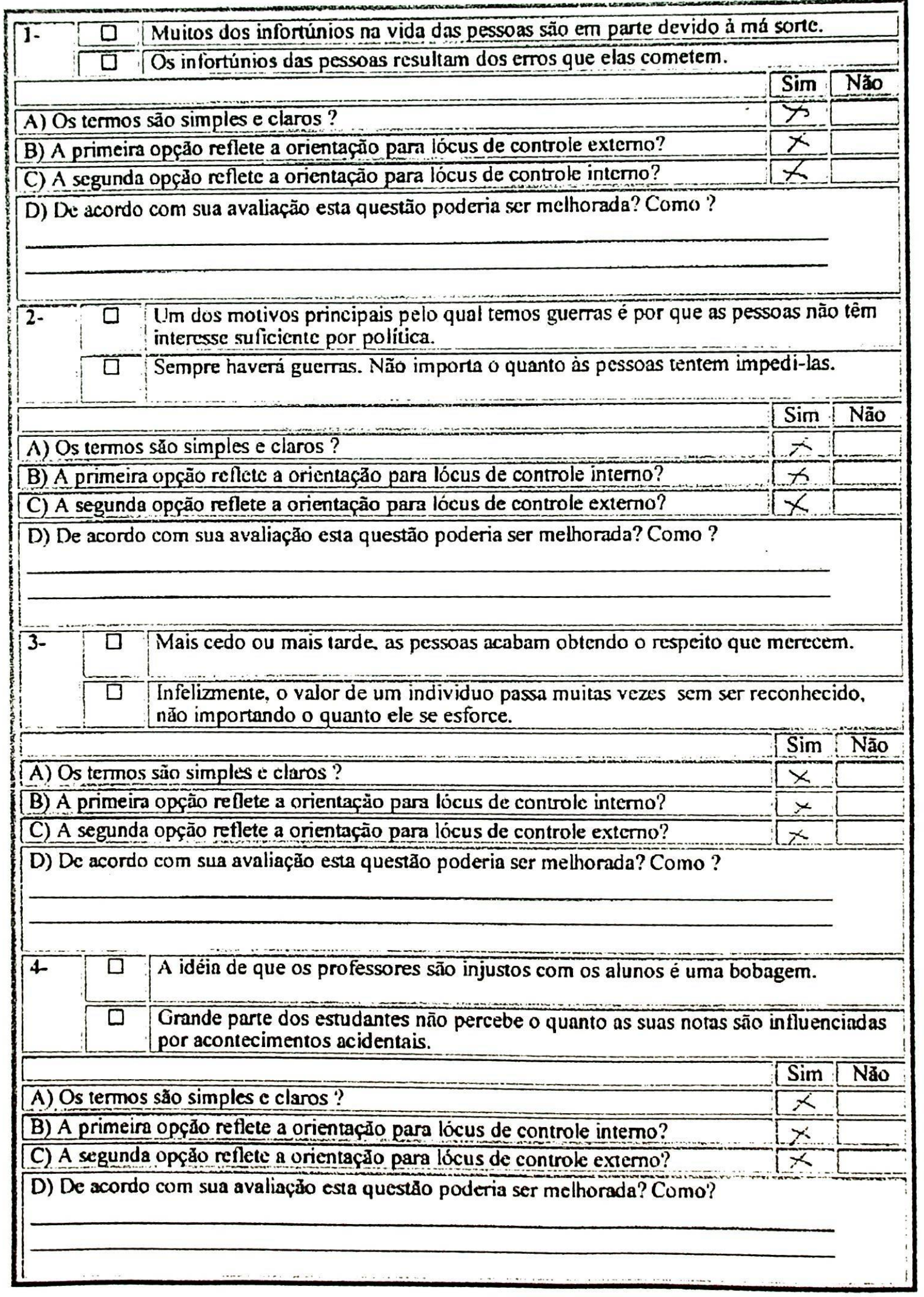




\section{APÊNDICE XVII - Parecer de Luiz Fernando Bacchareti (continuacão)}

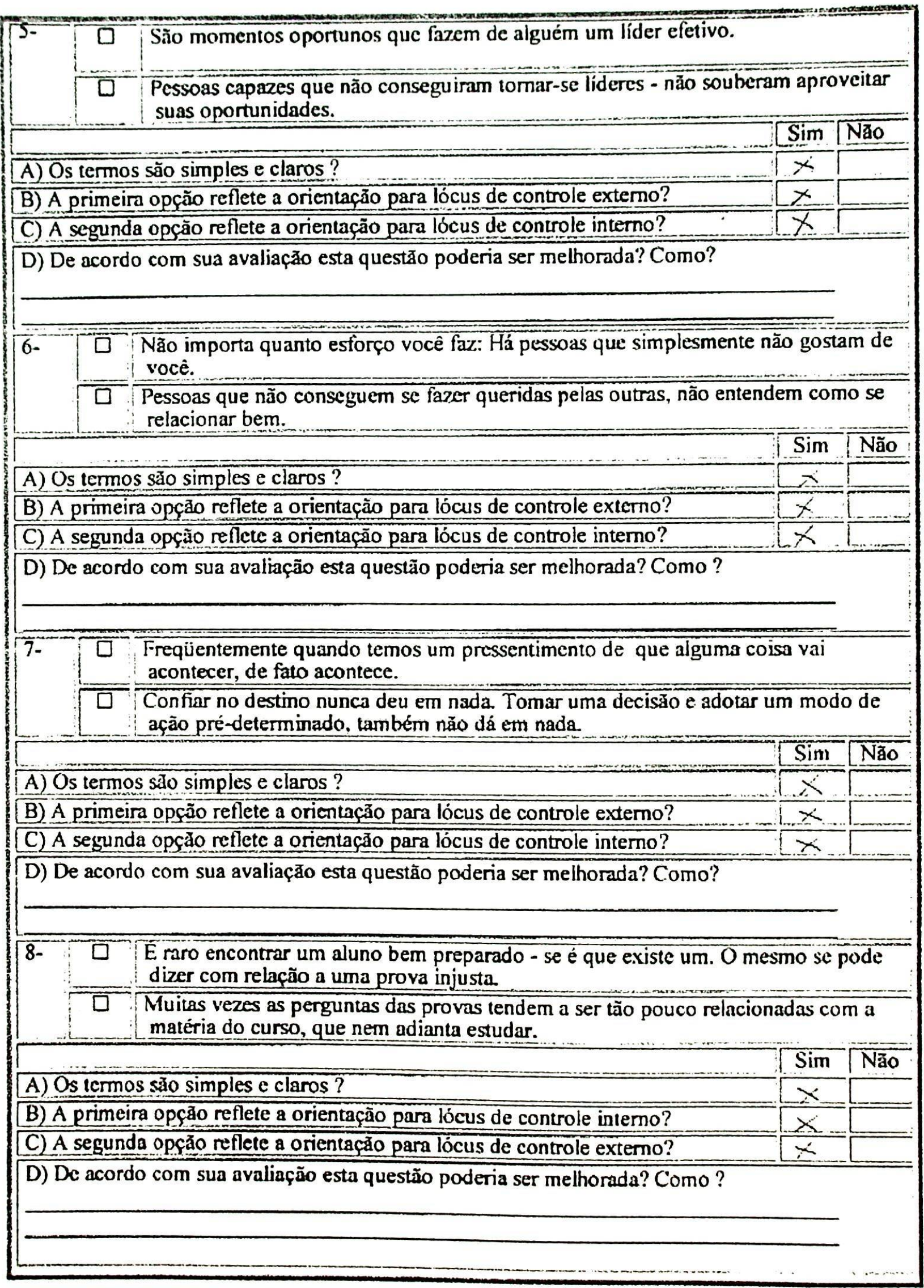




\section{APÊNDICE XVII - Parecer de Luiz Fernando Bacchareti (continuacão)}

\begin{tabular}{|c|c|}
\hline 9- $\quad \square$ & O sucesso é questão de muito trabalho. A sorte tem pouco ou nada a ver com isso. \\
\hline$\square$ & $\begin{array}{l}\text { Conseguir um bom emprego depende principalmente de se estar no lugar certo, na } \\
\text { hora certa }\end{array}$ \\
\hline
\end{tabular}

A) Os termos são simples e claros?

B) A primeira opção reflete a orientaçào para lócus de controle interno?

C) A segunda opcăo reflete a orientação para lócus de controle externo?

D) De acordo com sua avaliação esta questāo poderia ser melhorada? Como?

10- $\square$ cidadão comum pode exercer uma certa influência nas decisóes do governo.

Este mundo é governado pelos poucos que estão no poder, e um cidadão qualquet não pode fazer nada a respeito disso.

A) Os termos são simples e claros?

B) A primeira opçăo reflete a orientacào para lócus de controle interno?

C) A segunda opção reflete a orientação para lócus de controle externo?

D) De acordo com sua avaliação esta questão poderia ser melhorada? Como ?

11- $\square$ Quando fazemos planos, quase sempre estamos certos de que podemos executá-los.

- Nem sempre é prudente planejar com muita antocedência, porque muitas coisas acabam sendo. de uma maneira ou de outra - uma questão de boa ou má sorte.

A) Os termos são simples e claros?

B) A primeira opçảo reflete a orientaçāo para lócus de controle intemo?

C) A segunda opfão reflete a orientação para lócus de controle externo?

D) De acordo com sua avaliaçåo esta questão poderia ser melhorada? Como ?

12- $\square$ Para conseguirmos aquilo que queremos, tem muito pouco ou nada haver com a sorte.

Muitas vezes podemos decidir o que fazer, simplesmente tirando a sorte com uma moeda.

A) Os termos sảo simples e claros?

B) A primeira opfão reflete a orientacão para lócus de controle interno?

C) A segunda opfão reflete a orientacăo para lócus de controle externo?

D) De acordo com sua avaliação esta questão poderia ser melhorada? Como ? 


\section{APÊNDICE XVII - Parecer de Luiz Fernando Bacchareti (continuação)}

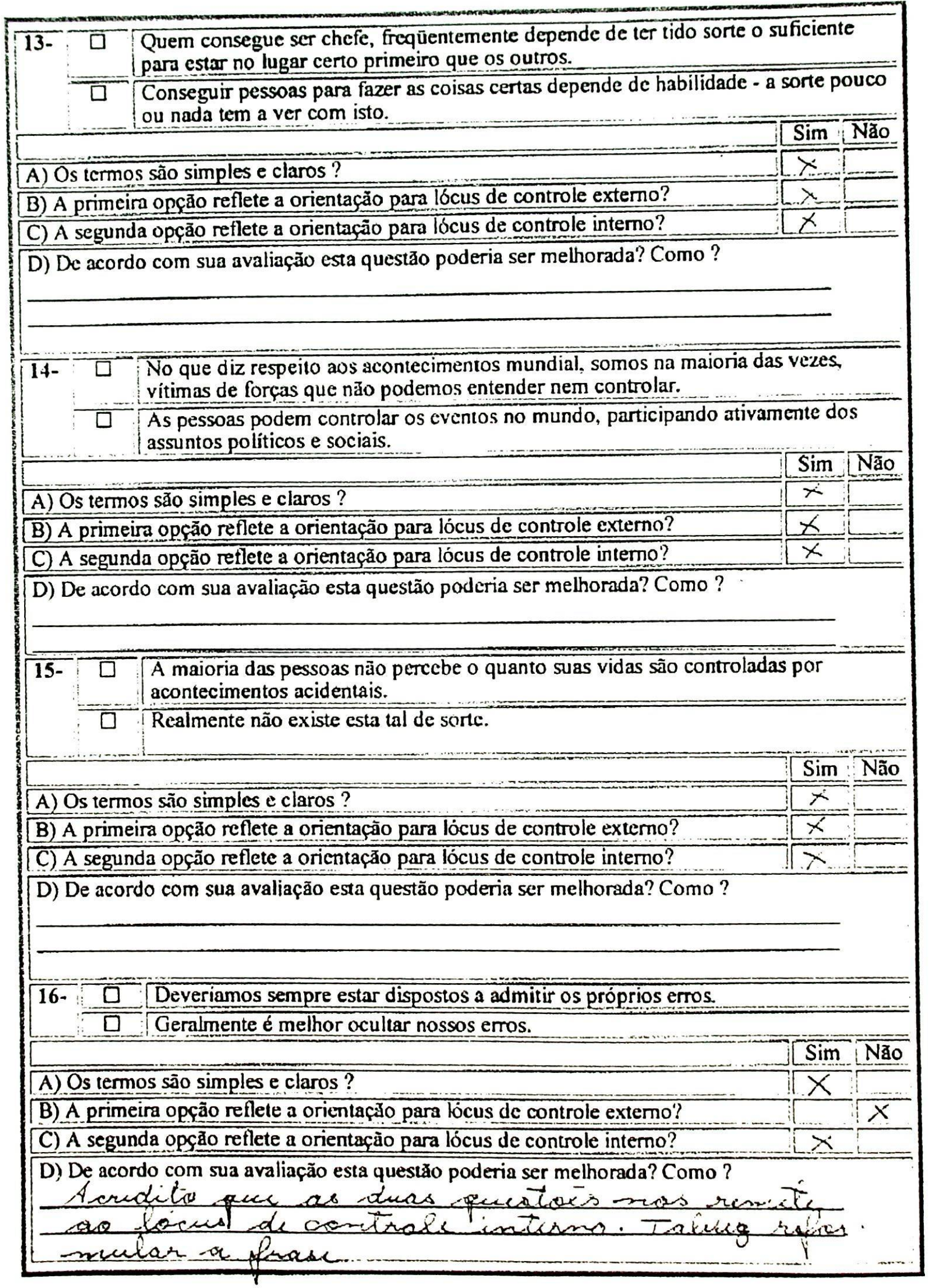




\section{APÊNDICE XVII - Parecer de Luiz Fernando Bacchareti (continuação)}

17- $\square$ Edificil saber se uma pessoa realmente gosta ou não de você.

[] A quantidade de amigos que vocé tem, depende do quanto vocé é legal.

A) Os termos sáo simples e claros?

B) A primeira opcāo reflete a orientação para lócus de controle externo?

C) A segunda opcão reflete a orientação para lócus de controle interno?

D) De acordo com sua avaliação esta questão poderia ser melhorada? Como ?

18- $\square$ No fim das contas, às coisas ruins acabam sendo compensadas pelas coisas boas.

A maioria dos infortúnios é o resultado da falta de habilidade, da ignorância, da preguiça ou das três.

A) Os termos são simples e claros?

B) A primeira opção reflete a orientaçăo para lócus de controle externo?

C) A segunda opcăo reflete a orientacão para lócus de controle interno?

D) De acordo com sua avaliação esta questão poderia ser melhorada? Como ?

19- Com bastante esforço pode-se eliminar a corrupção politica.

E dificil para as pessoas conseguir controle sobre aquilo que os politicos fazem em seus escritórios.

A) Os termos são simples e claros?

B) A primeira opcão reflete a orientaçăo para lócus de controle interno?

C) A segunda opção reflete a orientação para lócus de controle externo?

D) De acordo com sua avaliação esta questão poderia ser melhorada? Como ?

20- $\square$ As vezes, năo dá para entender como os professores chegam as notas que dăo. Há uma ligacáa direta entre o quanto se estuda e as notas que se tira.

A) Os termos são simples e claros?

B) A primeira opfão reflete a orientacão para lócus de controle externo?

C) A segunda opcão reflete a orientação para lócus de controle intemo?

D) De acordo com sua avaliaçăo esta queståo poderia ser melhorada? Como ?

\begin{tabular}{|c|c}
\hline Sim & Năo \\
\hline$x$ & \\
\hline$x$ & \\
\hline$x$ & \\
\hline
\end{tabular}




\section{APÊNDICE XVII - Parecer de Luiz Fernando Bacchareti (continuação)}

21- U Um bom lider espera que as pessoas decidam por elas mesmas, o que devem fazer

A) Os termos são simples e claros ?

B) A primeira opfão reflete a orientaç̄o para lócus de controle externo?

C) A segunda opção reflete a orientação para lócus de controle interno?

D) De acordo com sua avaliação esta questão poderia ser melhorada? Como ?

22- प Muitas vezes, acreditamos que temos pouca influência sobre as coisas que nos acontecem.

E impossivel acreditarmos que o acaso ou a sorte tenham um papel importante em nossas vidas.

A) Os termos são simples e claros?

B) A primeira opfão reflete a orientaçảo para lócus de controle externo?

C) A segunda opção reflete a orientação para lócus de controle interno?

D) De acordo com sua avaliação esta questão poderia ser melhorada? Como ?

23- $\quad$ As pessoas sảo solitárias porque não procuram ser amigáveis.

Não adianta se esforçar muito para agradar as pessoas - se elas gostam de você, é porque simplesmente gostam de você.

A) Os termos são simples e claros?

B) A primeira opçào reflete a orientaçảo para lócus de controle interno?

C) A segunda opção reflete a orientação para lócus de controle externo?

D) De acordo com sua avaliação esta questão poderia ser melhorada? Como ?

24- $\square$ Aquilo que nos acontece é o resultado de nossas próprias ações.

[ As vezes, parece que temos pouco controle sobre os rumos que nossas vidas estão tomando.

A) Os termos sao simples e claros?

B) A primeira opção reflete a orientaç̃o para lócus de controle interno?

C) A segunda opção reflete a orientaçāo para lócus de controle externo?

D) De acordo com sua avaliação esta questão poderia ser melhorada? Como ? 


\section{APÊNDICE XVII - Parecer de Luiz Fernando Bacchareti (continuação)}

25- Na maioria das vezes. nāo dá para entender porque os políticos se comportam desta ou daquela forma.

(1) No final, as pessoas é que são responsáveis pelos maus govemos, tanto cm nivel nacional quanto local.

A) Os termos sáo simples e claros?

B) A primeira opgăo reflete a orientaçāo para lócus de controle extemo?

C) A segunda opfāo reflete a orientaça para lócus de controle intemo?

D) De acordo com sua avaliação csta questão poderia ser melhorada? Como ?

Outras sugestoes:

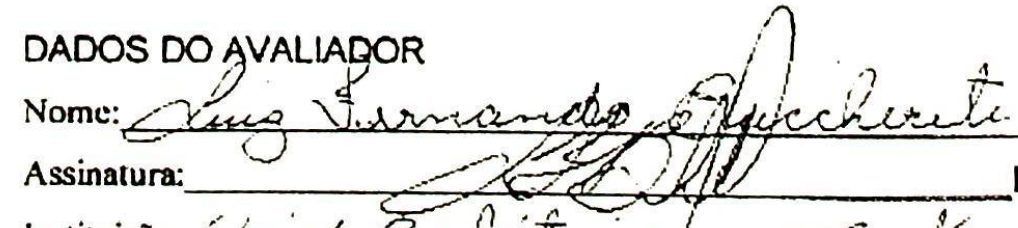

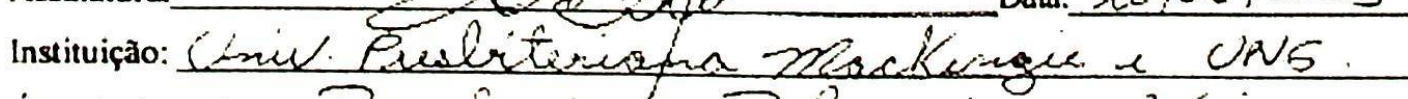

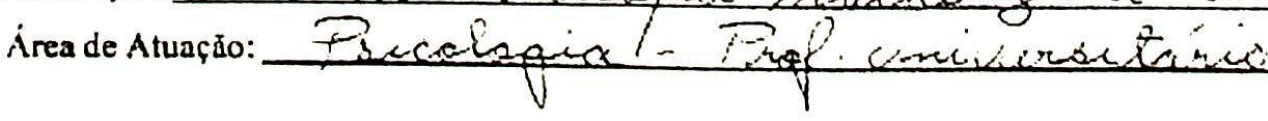




\title{
APÊNDICE XVIII - Parecer de Luiza Klein Alonso
}

\section{ESCALA DE LÓCUS DE CONTROLE}

\author{
Avaliação de Instrumento
}

Luiza Klein Alonso

Os 25 itens da "Escala de Lócus de Controle"( ELC) conservam sua atualidade e pertinência quanto à linguagem e aos temas propostos para reflexão.

A revisão técnica do instrumento detectou apenas 3 pontos que poderiam ser modificados:

Questão 8: Com o propósito de deixar a linguagem realmente clara, proponho uma reconfiguração da primeira opção. Como sugestão, esta ficaria da seguinte forma:

"É raro encontrar uma prova injusta. O que existe são alunos mal preparados."

Questão 16: acredito que houve uma troca.

A primeira opção se refere ao lócus de controle interno: "Deveriamos sempre estar dispostos a admitir os próprios erros."

A segunda opção deveria estar referida ao lócus de controle externo, o que implica que deveria ter outra redação: "Geralmente, todos escondem os seus erros."

Questão 18: Na primeira opção não há necessidade do uso de crase. 


\section{APÊNDICE XIX - Material entreque à comissão julgadora sobre a avaliação da Escala multidimensional de lócus de controle do esporte: segunda fase do processo de construcão do instrumento}

\section{Prezado Avaliador}

Em prosseguimento à pesquisa sobre crenças religiosas e lócus de controle no esporte. Eu, Paulo Felix Marcelino Conceição - aluno do curso de Pós-Graduação em nível de Mestrado, na Escola de Educação Física e Esporte da Universidade de São Paulo, apresento a seguir: a escala de lócus de controle do esporte. A possibilidade e a necessidade do desenvolvimento de um instrumento específico para o esporte, se deu mediante os seguintes fatores:

A) Parecer positivo emitido por três juízes - psicólogos, consultados quanto à validade dos 46 itens criados por Rotter (1906) para medir a orientação do constructo lócus de controle, no que se refere a internalidade (23) e a externalidade (23).

B) A necessidade de simplificar o instrumento, devido a demandas específicas, inerentes ao ambiente esportivo, frente a algumas observações que foram feitas ao pesquisador, quanto ao possível número excessivo de questões da escala - 58 itens no total, 46 referentes ao lócus de controle e 12 questões "filler item"".

C) A posição de Portnoi (2000); Dela Coleta (1987) e Levenson (1973), entre outros, que admitem a multidimensionalidade do lócus de controle externo: "Lócus de Controle Externo pelo Acaso" (LCEA) e "Lócus de Controle Externo por Pessoas Poderosas" (LCEPP).

D) As pesquisas desenvolvidas por Rodrigues-Rosero (2002), Kurita (2001), Dela Coleta (1996) e Wallston (1992), entre outros, que concebem o lócus de controle como sendo uma característica geral de comportamento que se aplica em todas as situações da vida, que no entanto, admitem a possibilidade do desenvolvimento e utilização de escalas com design para áreas específicas - "Escala de Lócus de Controle da Saúde" (ELCS).

Frente a estes desafios e dificuldades, o pesquisador optou pelo desenvolvimento de uma escala de lócus de controle no esporte, buscando resgatar as idéias da teoria da aprendizagem social e da psicologia social, presentes na escala de Rotter (1906). Racionalizar o instrumento, com base na metodologia adotada por Levenson (1973) na construção de uma escala de lócus de controle com respostas do tipo "lickert" em estudos realizados na área clínica. E, criar uma linguagem dentro de contextos gerais e situações especificas ambientadas no esporte.

Segundo a concepção de Pais Ribeiro (1994) cada vez que se utiliza um instrumento de avaliação psicológica, deve-se questionar a validade e adequação deste instrumento. Com base nesta perspectiva, peço a inestimável gentileza de emitir um parecer quanto à validade e adequação dos 24 itens que resultam na "Escala de Lócus de Controle do Esporte" (ELCE) 
APÊNDICE XIX - Material entreque à comissão julgadora sobre a avaliacão da Escala multidimensional de lócus de controle do esporte: segunda fase do processo de construcão do instrumento (continuação)

\section{ESCALA DE LÓCUS DE CONTROLE NO ESPORTE}

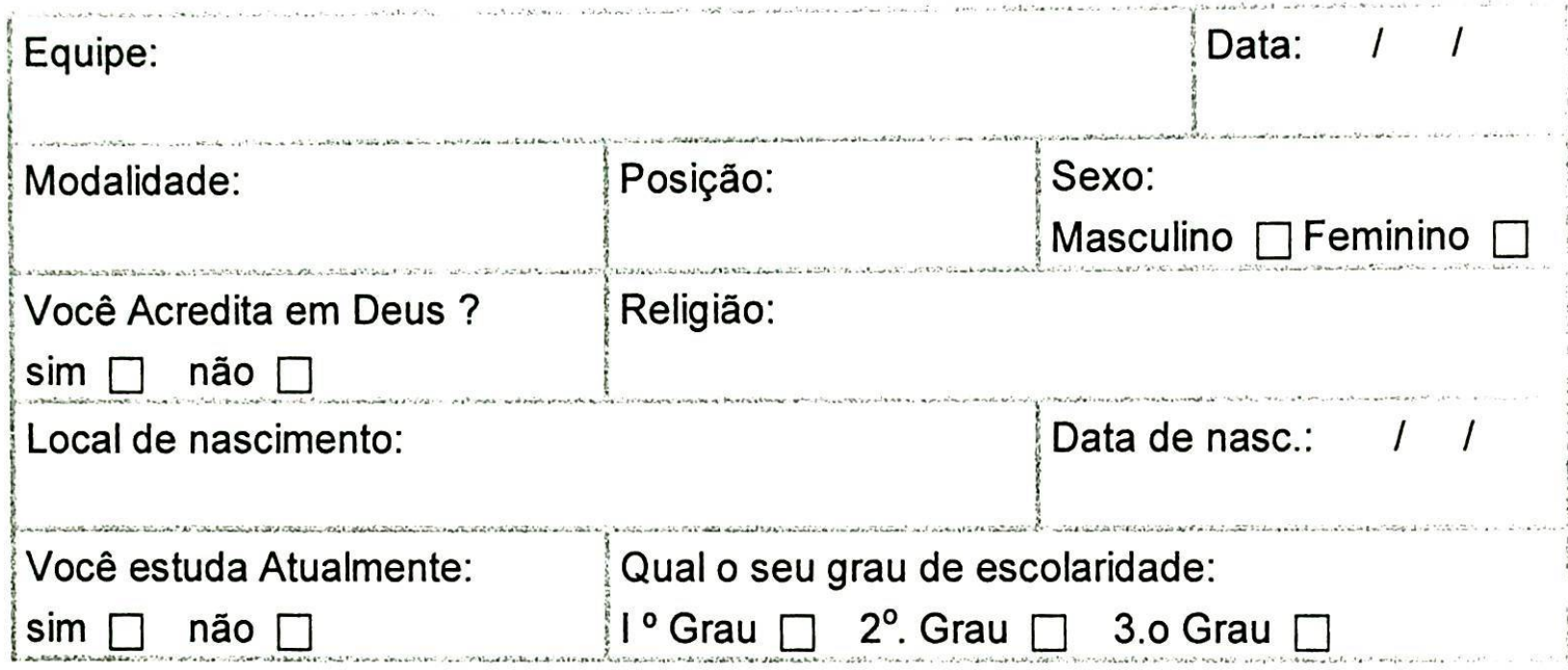

A seguir você encontra um questionário sobre como os atletas pensam de forma geral sobre o esporte. Após ler cada uma das frases, você deverá fazer um circulo no símbolo que melhor representar a sua opinião, como no exemplo da figura abaixo.
(-) CONCORDO TOTALMENTE
(6) DISCORDO TOTALMENTE
(i) CONCORDO
$\because$ DISCORDO
$\bigodot$ CONCORDO PARCIALMENTE
$\Theta$ DISCORDO PARCIALMENTE

Procure não demorar muito em cada frase, responda de acordo com aquilo que você pensa normalmente. Não existem respostas certas ou erradas. Suas respostas são confidenciais e seu anonimato será preservado 


\section{APÊNDICE XIX - Material entreque à comissão julgadora sobre a avaliacão da Escala de multidimensional de lócus de controle do esporte (continuação).}

\begin{tabular}{|c|c|c|c|c|c|c|c|c|}
\hline \multirow{2}{*}{$\begin{array}{l}\ddot{~} \text { DISCORDO TOTALMENTE } \\
\ddot{\sim} \text { CONCORDO TOTALMENTE }\end{array}$} & \multirow{2}{*}{ 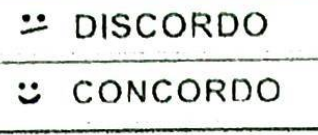 } & \multicolumn{7}{|c|}{$\because$ DISCORDO PARCIALMENTE } \\
\hline & & \multicolumn{7}{|c|}{$\because$ CONCORDO PARCIALMENTE } \\
\hline & & & $\nabla$ & $\nabla$ & $\nabla$ & $\nabla$ & $\nabla$ & \\
\hline \multicolumn{3}{|c|}{$\begin{array}{l}\text { A instabilidade na carreira esportiva, resultaria das dificuldades } \\
\text { próprios atletas. }\end{array}$} & $\ddot{\sim}$ & $\ddot{-}$ & $\ddot{-}$ & $\ddot{-}$ & $\ddot{*}$ & $\ddot{v}$ \\
\hline \multicolumn{3}{|c|}{$\begin{array}{l}\text { Frequientemente, quando se tem um pressentimento de que algo } \\
\text { vai acontecer, de fato acontece. }\end{array}$} & $\ddot{n}$ & $\ddot{-}$ & $\ddot{-}$ & $\ddot{-}$ & $\ddot{v}$ & $\ddot{~}$ \\
\hline \multicolumn{3}{|c|}{$\begin{array}{l}\text { Sc as pessoas gostam de um atlcta, ć porque simplesmente } \\
\text { gostam, dai, näo adianta se esforçar muito para ser agradável. }\end{array}$} & $\ddot{n}$ & $\ddot{-}$ & $\ddot{-}$ & 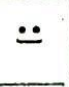 & $\ddot{v}$ & $\ddot{ن}$ \\
\hline \multicolumn{3}{|c|}{$\begin{array}{l}\text { Os resultados obtidos no esporte de rendimento, são } \\
\text { proporcionais aos yraus de dedicaça dos atletas. }\end{array}$} & $\ddot{n}$ & 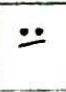 & $\dot{-}$ & $\dot{x}$ & $\ddot{*}$ & $\ddot{v}$ \\
\hline \multicolumn{3}{|c|}{$\begin{array}{l}\text { O succsso no csportc ć questão de muito trabalho c persistência. } \\
\text { A sorte tem pouco, ou nada a ver com isto. }\end{array}$} & $\ddot{n}$ & $\ddot{-}$ & $\ddot{-}$ & $\ddot{-}$ & $\ddot{v}$ & $\ddot{v}$ \\
\hline \multicolumn{3}{|c|}{$\begin{array}{l}\text { Não se deve fazer planos com muita antecedência, porque muitas } \\
\text { coisas acabam sendo uma questão de sorte ou azar. }\end{array}$} & $\ddot{n}$ & $\ddot{~}$ & $\ddot{\circ}$ & 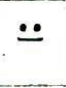 & $\ddot{v}$ & $\ddot{v}$ \\
\hline \multicolumn{3}{|c|}{$\begin{array}{l}\text { Sa momentos oportunos, que fazem de um atleta qualquer, } \\
\text { um super atleta. }\end{array}$} & $\ddot{n}$ & $\ddot{0}$ & $\ddot{-}$ & $\ddot{-}$ & $\ddot{ت}$ & $\ddot{v}$ \\
\hline \multicolumn{3}{|c|}{$\begin{array}{l}\text { Sempre haverá violência entre as grandes torcidas, não importa o } \\
\text { que se faça para tentar evitá-la. }\end{array}$} & $\ddot{n}$ & $\ddot{-}$ & $\ddot{-}$ & $\ddot{-}$ & $\ddot{v}$ & $\ddot{~}$ \\
\hline \multicolumn{3}{|c|}{$\begin{array}{l}\text { Um atleta profissional pode excrcer uma certa influência, nas } \\
\text { decisöes do ministerio do esporte. }\end{array}$} & $\ddot{n}$ & $\ddot{-}$ & $\ddot{-}$ & $\ddot{-}$ & $\ddot{v}$ & $\ddot{~}$ \\
\hline \multicolumn{3}{|c|}{$\begin{array}{l}\text { Para ser um atleta de sucesso, depende de estar no esporte certo, } \\
\text { na equipe certa, e na hora certa. }\end{array}$} & $\ddot{n}$ & $\ddot{\prime}$ & $\ddot{-}$ & $\ddot{-}$ & $\ddot{v}$ & $\ddot{v}$ \\
\hline \multicolumn{3}{|c|}{$\begin{array}{l}\text { Infelizmente, o valor de um atleta passa muitas vezes sem ser } \\
\text { reconhecido, näo importa o quanto ele se esforce. }\end{array}$} & $\ddot{n}$ & $\ddot{-}$ & $\ddot{-}$ & $\ddot{=}$ & $\ddot{v}$ & $\ddot{v}$ \\
\hline \multicolumn{3}{|c|}{$\begin{array}{l}\text { Ás vezes, um atleta pode decidir melhor o que fazer, } \\
\text { simplesmente tirando a sorte com uma moeda. }\end{array}$} & $\ddot{n}$ & $\ddot{-}$ & $\ddot{-}$ & $\ddot{-}$ & ت & $\ddot{U}$ \\
\hline \multicolumn{3}{|c|}{$\begin{array}{l}\text { No mundo dos esportes, na maioria das vezes, os atletas säo } \\
\text { vitimas de forças e pressões que não conseguem controlar. }\end{array}$} & $\ddot{n}$ & $\ddot{-}$ & $\ddot{-}$ & 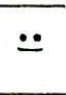 & $\ddot{v}$ & $\ddot{v}$ \\
\hline \multicolumn{3}{|c|}{$\begin{array}{l}\text { Se um atleta, vai sofrer ou não, um acidente durante o } \\
\text { desenvolvimento de um jogo, isso é uma questão de sorte. }\end{array}$} & $\ddot{n}$ & $\ddot{-}$ & $\ddot{-}$ & $\ddot{-}$ & $\ddot{ت}$ & $\ddot{v}$ \\
\hline \multicolumn{3}{|c|}{$\begin{array}{l}\text { O esporte é controlado pelos poucos que estão no poder, e não há } \\
\text { nada, que um simples atleta possa fazer a respeito disso. }\end{array}$} & $\ddot{n}$ & $\ddot{-}$ & $\ddot{-}$ & $\ddot{-}$ & $\ddot{v}$ & $\ddot{v}$ \\
\hline \multicolumn{3}{|c|}{$\begin{array}{l}\text { Durante um jogo qualquer, na hora "H", é Dcus quem mostra para } \\
\text { o atleta a direçäo certa. }\end{array}$} & $\ddot{n}$ & $\ddot{-}$ & $\ddot{-}$ & $\ddot{-}$ & $\ddot{~}$ & $\ddot{~}$ \\
\hline \multicolumn{3}{|c|}{$\begin{array}{l}\text { Na maioria das vezes, não dá para entender porque os politicos, } \\
\text { agem desta ou daquela forma, com relação ao esporte. }\end{array}$} & $\ddot{n}$ & $\ddot{-}$ & $\ddot{-}$ & $\ddot{-}$ & ت & $\ddot{~}$ \\
\hline \multicolumn{3}{|c|}{$\begin{array}{l}\text { É raro encontrar um resultado de jogo injusto, o que existe, säo } \\
\text { atletas mal preparados. }\end{array}$} & $\ddot{n}$ & $\ddot{-}$ & $\ddot{-}$ & $\ddot{-}$ & $\ddot{v}$ & ت \\
\hline \multicolumn{3}{|c|}{$\begin{array}{l}\text { A idéia de que os técnicos são injustos com os atletas, ć uma } \\
\text { bobagem. }\end{array}$} & $\ddot{n}$ & $\ddot{-}$ & $\ddot{-}$ & $\ddot{-}$ & $\ddot{~}$ & $\ddot{~}$ \\
\hline \multicolumn{3}{|c|}{$\begin{array}{l}\text { No esporte, muitas vezes é dificil saber quando as pessoas gostam } \\
\text { realmente ou não de um atleta. }\end{array}$} & $\ddot{n}$ & $\ddot{\circ}$ & $\ddot{-}$ & $\ddot{्}$ & $\ddot{ت}$ & $\ddot{~}$ \\
\hline \multicolumn{3}{|c|}{$\begin{array}{l}\text { E impossivel acreditar que o acaso ou a sorte possam ter uma um } \\
\text { papel importante na carreira de uma atleta. }\end{array}$} & $\ddot{n}$ & $\ddot{\circ}$ & $\ddot{-}$ & $\ddot{-}$ & $\ddot{v}$ & $\ddot{v}$ \\
\hline \multicolumn{3}{|c|}{$\begin{array}{l}\text { Na maioria das vezes, sào os detentores do poder esportivo, quem } \\
\text { decidem os rumos da vida do atleta. }\end{array}$} & $\ddot{n}$ & $\ddot{\sim}$ & $\ddot{-}$ & $\ddot{-}$ & $\ddot{v}$ & ت \\
\hline \multicolumn{3}{|c|}{$\begin{array}{l}\text { Um atleta pode decidir como vai ser o seu futuro, de acordo com } \\
\text { aquilo que ele mesmo faz no presente. }\end{array}$} & $\ddot{n}$ & $\ddot{-}$ & $\ddot{-}$ & $\ddot{-}$ & $\ddot{v}$ & $\ddot{~}$ \\
\hline \multicolumn{3}{|c|}{$\begin{array}{l}\text { No fim das contas, as coisas ruins acabam sendo compensadas } \\
\text { pelas coisas boas. }\end{array}$} & $\ddot{x}$ & $\ddot{-}$ & $\ddot{-}$ & $\ddot{-}$ & $\ddot{~}$ & $\ddot{~}$ \\
\hline
\end{tabular}


APÊNDICE XX - Comissão julgadora da escala de lócus de controle do esporte: segunda fase do processo de construcão do instrumento

No processo de construção da escala multidimensional de lócus de controle do esporte, foram eliminadas uma das duas questões que compões os 24 da escala de J. B. Rotter, buscando-se adaptar o conteúdo das questōes selecionadas à linguagem e conteúdos inerentes ao ambiente esportivo.

Três juizes avaliaram o instrumento na primeira fase:

- Luiza Klein Alonso

- Luiz Fernando Bacchereti

- Marilia Ferreira Dela Coleta

Os pareceres dos juízes encontram-se a seguir nas paginas: 166, 169, 171. 
167

APÊNDICE XXI - Parecer de Luiza Klein Alonso

Parecer

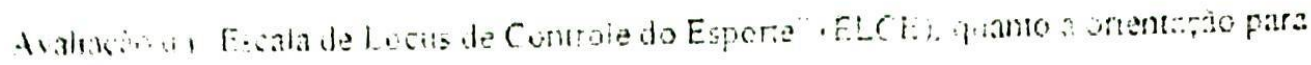

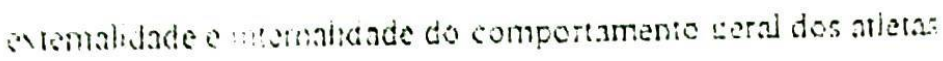

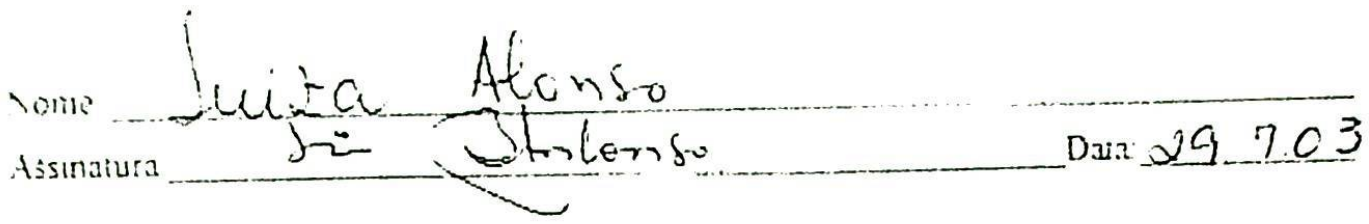

1. Quanta a cetetica e validade da escala lickert de pictogramas:

Concordo $\square$ Discordo $\square$ Sugestoes as modificaföm ficancm muts boas deixana ol insmumento + claro e eficiernte.

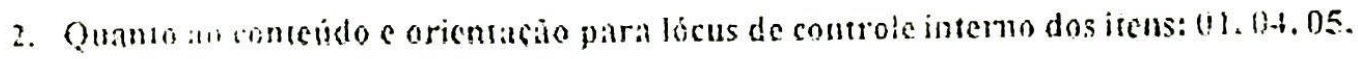

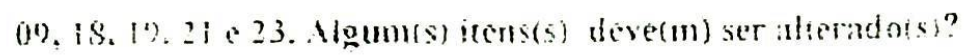

Concordo $\square$ Discordo $\square$ Emqual(s)sentido(s)" Os ithms 01 2 21 precidam de caltuacto : no item 1 acutentar a pupecicteor "dos".

antifo "uma". no item 21 perbhair 0 
168

APÊNDICE XXI - Parecer de Luiza Klein Alonso (continuacão)

3. Quanto ats conteudo e nrientacio para lócus de controle extemo pelo acasn. dos

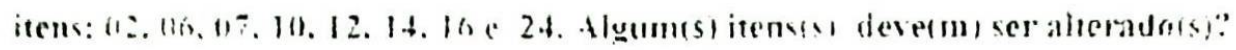
Emqual(s)sentido(s)? Efter be m clavos Concordo $\square$ Discordo $\otimes$

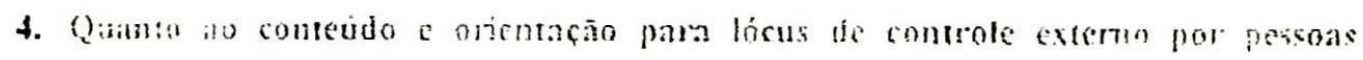
poderusas dos itens : $03,08.11,13,15,17,20 \mathrm{e} 22$. Algum(s) itensis) deve(m) ser ahteradoris:

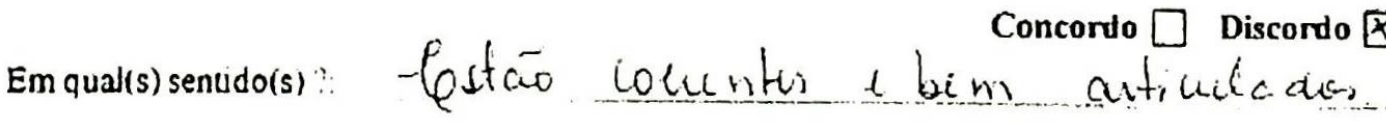




\section{APÊNDICE XXII - Parecer de Luiz Fernando Bacchereti}

\section{Parecer}

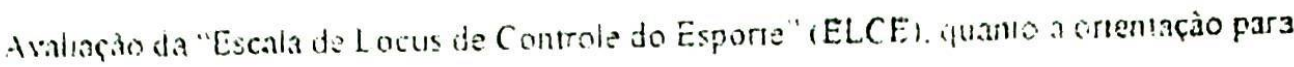
evemadidade emtemalidade do comportamento geral dos aietas

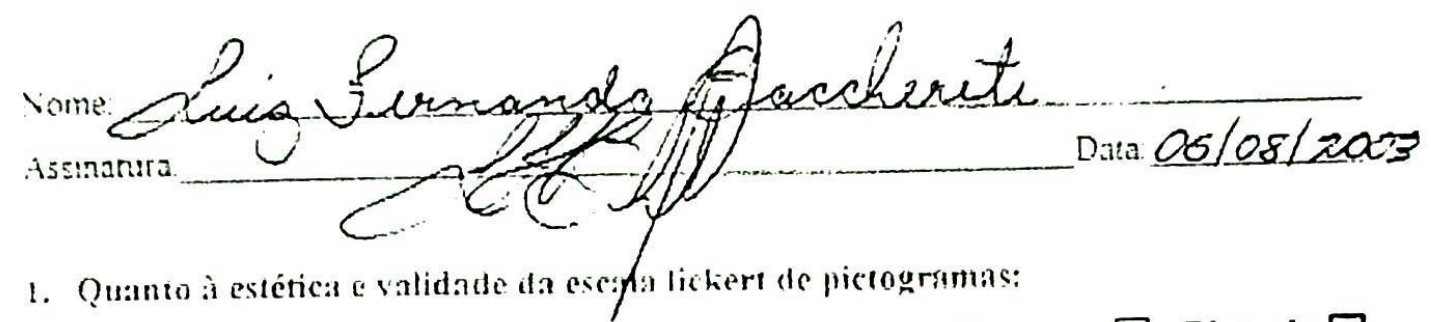

Concordo $\square$ Discordo $\square$

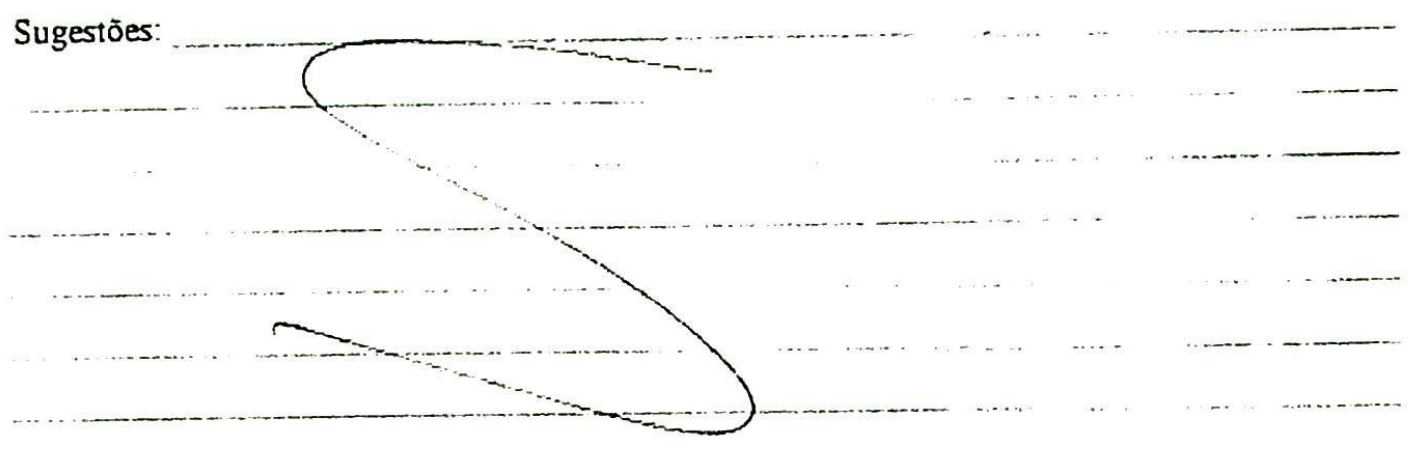

2. Quano an contevido e orientaç̃o para lócus de controle interno dos itens: $01,04,05$. Y)9. 18. 19,21 e 23 . Algum(s) itens(s) deve(m) scr alterado(s)"

\section{Concordo $\square$ Discordo $\square$}

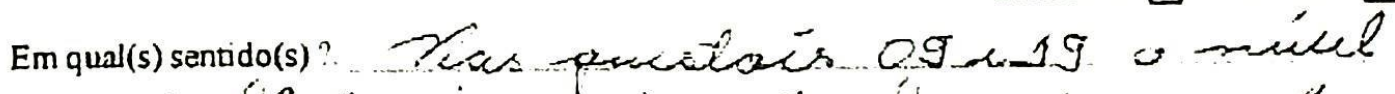

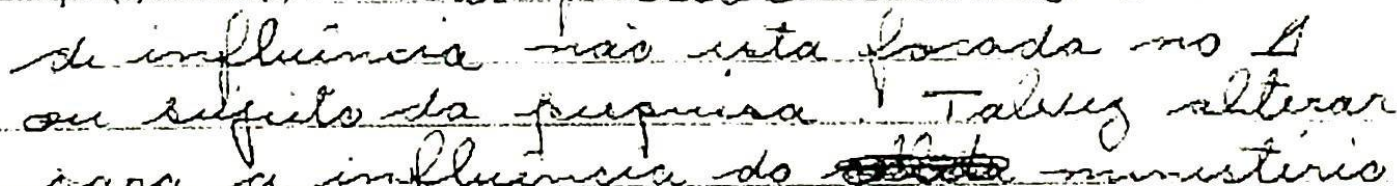

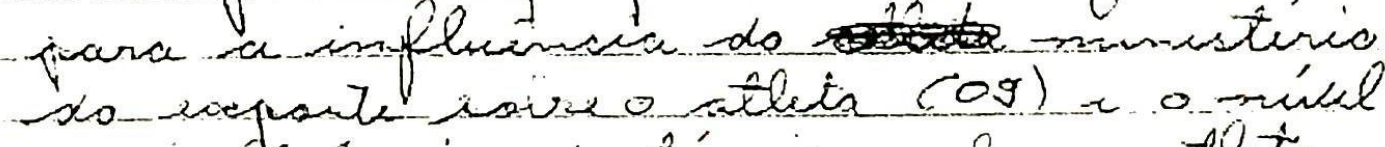

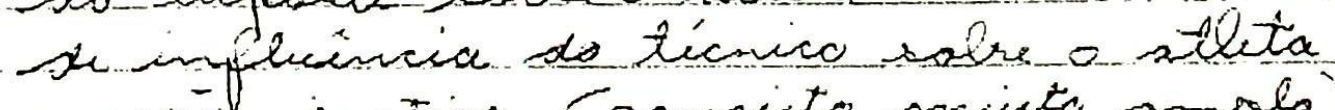

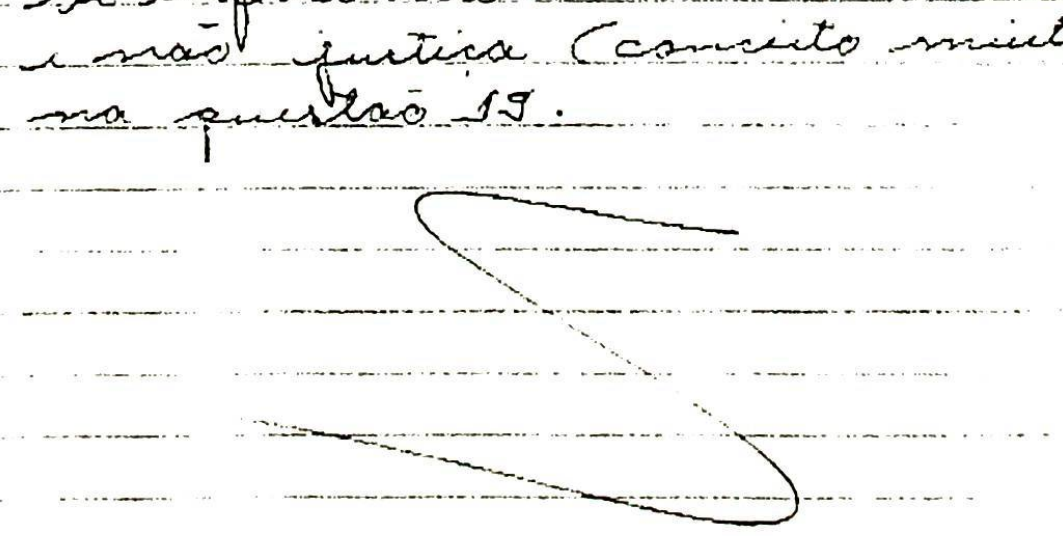


170

APÊNDICE XXII - Parecer de Luiz Fernando Bacchereti (continuação)

3. Quamo ao conteudo e orientacio para lócus de controle externo pelo acaso. dos itens: $02.06 .07 .10 .12 .14 .16 \mathrm{e} 24.1$ Igum(s) itens(s) deve(m) ser alterado(s)?

Concordo $\square$ Discordo $\square$

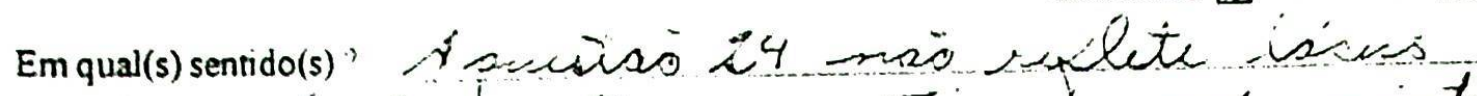
ac conirale isctirno. Fisal mints Vrage.

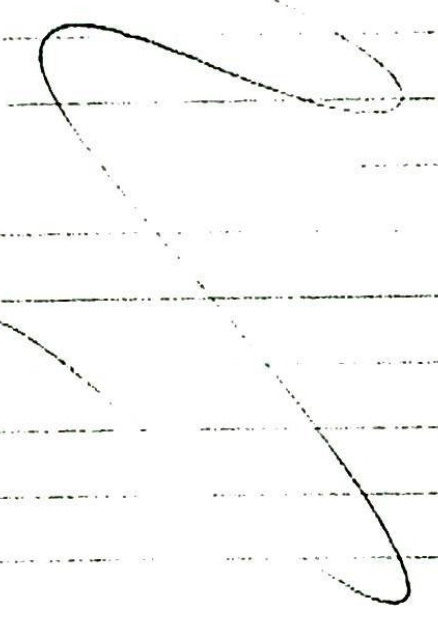

4. Quanto ao contenio e orientaç̃o pama lócus de controle extemo por pessoas poderos:ts. dos itens : 03.08 .11 . 13. 15.17 .20 e 22 . Algumisitensisi deremi ser alterado(s)"?

Concordo $\square$ Discordo

Em qual(s) sentido(s)" 11 - Sun oce rewa hecedo par Tun-?

$13-$ Guc provocis?

15
20

Cotas rueatai padura un meler trabchestar, alsurvando a repertas prue fodvia dar millar dunrima. menta no raciacinio da rijita. 


\title{
APÊNDICE XXIII - Parecer de Marilia Ferreira Dela Coleta
}

\section{Paulo Félix}

De:

Para:

Enviada em:

Assunto:

\author{
"Mardia Ferreira Dela Coleta" < mariliacoleta@enetec.com.br \\ "Paulo Fèlix" < paulo-felix@uol.com.br \\ quinta-feira, 7 de agosto de 2003 16:38 \\ Re: locus de controle no esporte
}

Prezado Paulo

Fico teliz em ter ajudado.

A escala unidimensional de Rotter de 1966 (um só continuo vanando da internalidade lolal até a extemalidade total - a l-E de Rotter foi traduzida e validada pelo meu marido em 1979) foi analisada posteriormente por diversos estudiosos, qua chegaram à conclusào que o locus nào é unidimensional. Um destes autores é Levenson (1974) que por isso criou a escala com 3 dimensoes: uma intema, outra extema outros poderosos e outra para a externalidade - acaso. A escala multidimensional de Levenson original é respondida em 6 opços, como a sua proposta. Quando eu a traduzi e validei. suger o uso com 5 opposes, devido a estudos anteriores terem mostrado a dificuldade dos respondentes para compreender a diferença entre os itens centrais e também porque com 5 opф̧ßes haveria uma posiçăo central. Entretanto, alguns autores utilizam 7, 9 ou até 11 opçes de resposta, mas ná colocam o significado de cada uma porque seria mesmo dificil encontrar estes significados. Likert (1932) criou o "mélodo dos pontos somados" nas escalas psicométricas e. até onde eu sei. as opçes de resposta variam de 3 até mais de 10. mas são mais utilizadas as 5 ou 7 opçঠes de resposta. Pasquali (1996 e 1999) também nâo explica muito sobre as escalas tipo Likert.

Cada item que vocé utijiza na verdade nåo está avaliando se a resposta é interna ou externa, mas sim. se for um item de intemalidade. se a resposta mostra que o indiduo é intemo (quanto maior for a concordancia) ou se ELE NAO Ė INTERNO. ou seja. SE ELE NAO ACREDITA QUE É CAPAZ DE CONTROLAR AS CONSEQUÉNCIAS DE SUAS AÇOES. (as letras maiúsculas såo para enfatizar a diferença)

Se o item é externo-acaso. a resposta dirá o quanto o individuo acredita no acaso. sorie. azar. destino. etc. como controlador de sua vida (ou de sua carraira esportiva), se nảo acredita nada até acredita totalmente. mas NÁO DIRA SE ELE ACREDITA NELE MESMO (intemalidade). Portanto, cada item é destinado à medida de APENAS UMA das dimens 0 es do locus de controle. Quando a pessoa discorda que o acaso controla sua vida, isso nảo quer dizer que ele acha que é ele proprio quem controla. tanto é verdade que a correlaçăo entre as sub-escalas nunca é muito alta.

Quanto ao uso das cores. achei muito criativo. mas continuo achando acho que as expressōes (as centrais) náo são muito exalas com relaça ao significado delas. Porem, se vocé for cuidadoso na explicaçao ao sujeito, ele vai entender a forma de responder.

Bem, náo fique sem dormir por causa de minhas observaçőes. Sou meio exigente.

Um abraço.

Marilia

\author{
- Original Message --- \\ From: Qaulo Félix \\ To: Marilia Ferreira Dela Coleta \\ Sent: Thursday. August 07, 2003 2:35 PM
}

Subject: Re: locus de controle no esporte

Prezada Marilia,

Obrigado pela sua disposiçảo em ajudar na validaçăo. Mostrei seu parecer para o ineu crientador, ele ficou muito satisfeito. Todas as suas sugestoes seráo acatadas. Citar o seu nome em meu trabalho è mais do que uma honra. Seu parecer confere uma grande credibilidade a pesquisa.

Só estou em duvida quanto ao número de itens da escala. Quando optei por um numero par opcoes estava na verdade querendo resgatar a ideia de Rotter (1972) "Applications of a social learning theory of personality" concebendo o locus de controle em duas dimensóes - intemo e externo, apenas dando maior graude liberdade ao respondente. Quanto as dificuldades em responder escalas com mais de cinco pontos no Brasil, penso em usar a cor como artificio para facilitar o entendimento.

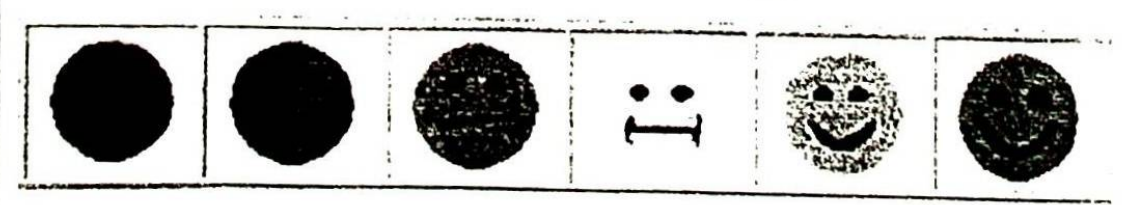

O que voce acha?

Um grande abraço. 


\section{APÊNDICE XXIII - Parecer de Marilia Ferreira Dela Coleta (continuacão)}

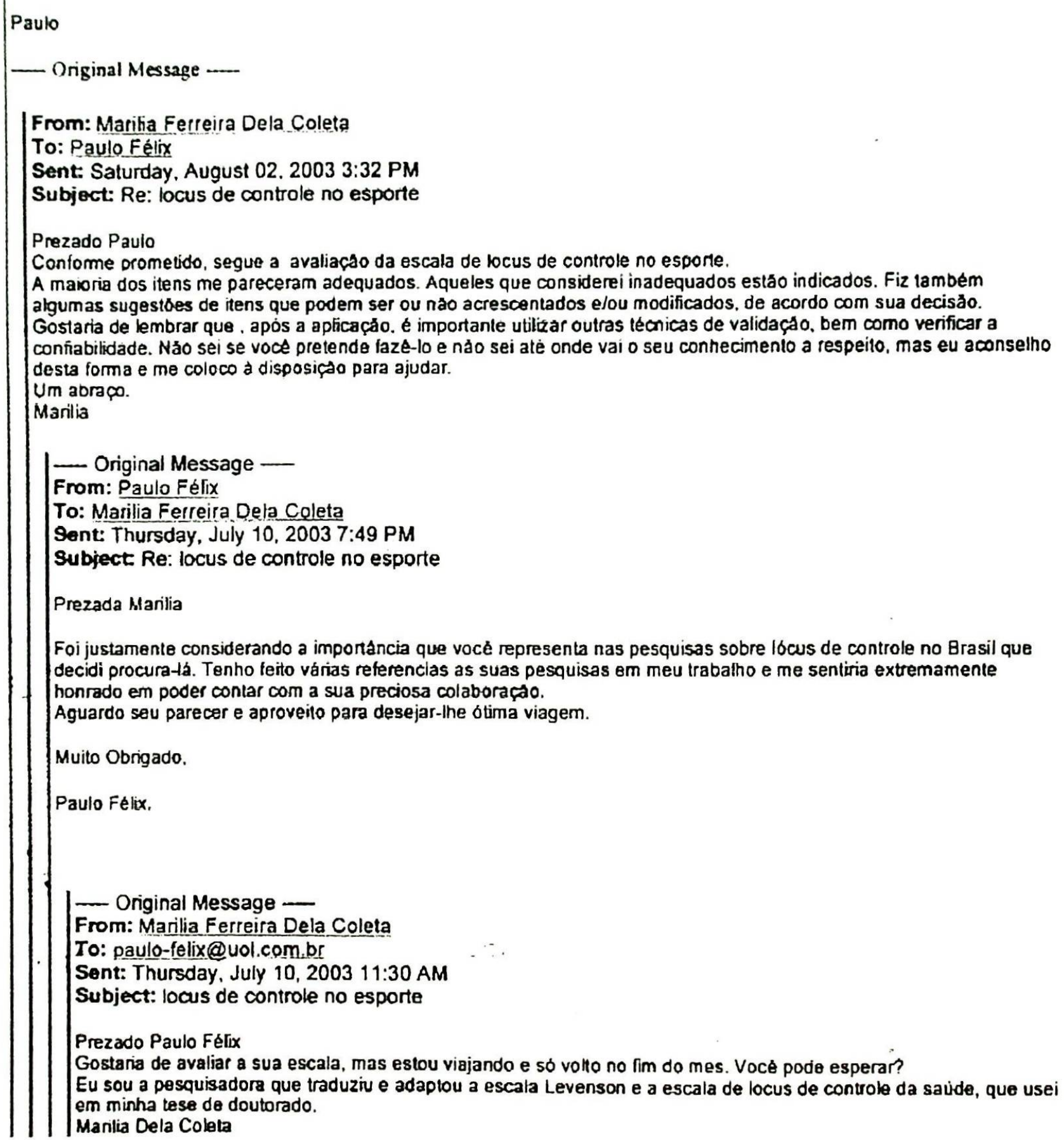




\section{APÊNDICE XXIII - Parecer de Marilia Ferreira Dela Coleta (continuação)}

\section{Parecer}

Avaliação da "Escala de Lócus de Controle do Esporte" (ELCE), quanto à orientaçio para extemalidade e internalidade do componamento geral dos atletas.

Nome: ___ Marnlia Ferreira Dela coleta

Assinatura:

Data:_2/8/2003..

1. Quanto à estética c validade da escala lickert (LIKERT) de pictogramas:

\section{Concordo $\square$ Discordo}

Sugestōes: _._. Excelente idéia, mas nâo concordo com as sels opçōes porque diversos estudos feiros no Brasil mostram que quando ha mais de 5 opçðes de resposta. as pessoas têm diñculdade para compreender. Sugiro 5 opçōes concordo toralmente. concordo ern parte, lou somente "concordo"; estou em durida (ou "indeciso", ou nào concordo nem discordo"), discordo em parte (ou "discorio"). discordo cotalmente.

2. Quanto ao conteúdo e orientaçāo para lócus de controle interno dos itens: 01, 04, 05. $09,18,19,21$ e 23 . Algum(s) itens(s) deve(m) ser alterado(s)?

Concordo

Discordo

Em qual(s) sentido(s)?

19 e 21 não refletem claramente a crenca no controle pessoal

Item 1-SLGESTÃO A instabilidade RESUTT + DAS DIFICULDADES

3. Quanto ao conteúdo e orientaçăo para lócus de controle externo pelo acaso, dos itens: $02,06,07,10,12,14,16$ e 24. Algum(s) itens(s) deve(m) ser alterado(s)?

Concordo $\square$ Discordo

Em qual(s) sentido(s) ?:

24 - nåo se refere ao controle pelo acaso, sorte, destino ou Deus.

4. Quan to ao conteúdo e orientação para lócus de controle extemo por pessoas poderosas, dos itens : $03,08,11,13,15,17,20$ e $22 . A \operatorname{lgum}(s)$ itens(s) deve(m) ser alterado(s)?

Concordo $\square$ Discordo $\square$

Em qual(s) senudo(s)?

$\mathbf{8}, 11$ c 20 - niko se referem ao controle por pessons poderosas. 


\section{APÊNDICE XXIII - Parecer de Marilia Ferreira Dela Coleta (continuação)}

\section{SUGESTO゚ES:}

Acaso:

- Murtas coisas que afetam a carreira de um atleta acontecem por acaso

- Eu posso reclamar dos cartolas, técnicos, treinadores, ou políticos, mas não posso fazer mais nada

- Aqueles que têm sucesso no esporte, realmente tiveram muita sorte

- Se for meu destino, eu me darei bem no esporte

- No esporte é possivel perder tudo que se conquistou sem saber porque

Internalidade:

- Se eu me dedicar bastante, posso ter sucesso no esporte

- Se eu tiver sucesso na carreira esportiva será principalmente por causa da minha capacidade

- Um fator importante no esporte, assim como na vida, é tomar as decisōes certas

- O atleta que segue corretamente uma carreira bem plancjada pode ficar tranqúilo quanto ao seu futuro

Outros poderosos do esporte

- A carteira de um atleta (esportista) depende muito de outras pessoas

- Se eu tiver sucesso no esporte, será por causa das pessoas que cuidaran da minha carreira

- Apesar de ter boa capacidade para o esporte, só conseguirei chegar onde quero se tiver a ajuda de pessoas importantes

- Para alcançar uma posição privilegiada no esporte, vou precisar da ajuda de pessoas influentes 
APÊNDICE XXIV - Tabela 10 - Fatores rotacionais varimax da Escala multidimensional de lócus de controle do esporte

FACTOR1 FACTOR2 EACTOR3 FACTOR4

\begin{tabular}{|c|c|c|c|c|}
\hline LC1 & 0.21933 & 0.63152 & -0.03132 & 0.12736 \\
\hline LC2 & 0.10301 & 0.05512 & 0.42978 & 0.28948 \\
\hline LC3 & 0.35021 & 0.58835 & -0.14024 & -0.27198 \\
\hline LC 4 & -0.12479 & 0.12910 & -0.03112 & 0.57338 \\
\hline LC5 & -0.16447 & 0.49673 & -0.11932 & 0.19581 \\
\hline LC 6 & 0.60523 & 0.17963 & -0.08741 & 0.27525 \\
\hline LC7 & 0.09082 & 0.45609 & 0.42717 & -0.03068 \\
\hline LC8 & 0.63421 & -0.09324 & 0.31695 & -0.05591 \\
\hline LC9 & -0.16469 & 0.08798 & 0.22323 & 0.64656 \\
\hline LC10 & 0.39212 & 0.16615 & 0.01298 & -0.12210 \\
\hline LC11 & 0.56662 & -0.12758 & -0.17114 & 0.17098 \\
\hline LC12 & 0.40140 & 0.26695 & 0.15015 & -0.04541 \\
\hline LC13 & 0.09872 & 0.02330 & 0.66388 & -0.19488 \\
\hline LC14 & 0.26335 & -0.15684 & 0.37900 & 0.31667 \\
\hline LC15 & 0.54122 & -0.16545 & 0.20814 & -0.04350 \\
\hline LC1 6 & 0.42263 & 0.08217 & -0.04948 & 0.35600 \\
\hline LC17 & -0.05435 & 0.37244 & 0.14327 & 0.02455 \\
\hline LC18 & 0.02278 & 0.57483 & 0.02715 & 0.25410 \\
\hline LC19 & -0.06418 & -0.01649 & 0.39897 & 0.02026 \\
\hline LC20 & 0.48604 & 0.06028 & 0.30462 & -0.14123 \\
\hline LC21 & 0.04329 & 0.06545 & -0.03025 & 0.39704 \\
\hline LC22 & 0.12118 & 0.11069 & 0.60100 & 0.02897 \\
\hline LC23 & 0.02238 & -0.14669 & 0.21140 & 0.21738 \\
\hline LC2 4 & 0.37518 & 0.11342 & -0.07681 & 0.5293 \\
\hline
\end{tabular}




\section{APÊNDICE XXV - Tabela 11 - Cargas dos fatores rotacionais da Escala multidimensional de lócus de controle do esporte: Fixando-se três fatores}

\begin{tabular}{|c|c|c|c|}
\hline & FACTORI & EACTOR2 & FACTOR3 \\
\hline $\mathrm{LC} 1$ & 0.35819 & 0.50377 & -0.18648 \\
\hline LC2 & 0.10554 & 0.21373 & 0.46394 \\
\hline LC3 & 0.54365 & 0.18250 & -0.41381 \\
\hline LC 4 & -0.21664 & 0.52302 & 0.15384 \\
\hline LC5 & -0.06154 & 0.47760 & -0.21868 \\
\hline LC 6 & 0.52504 & 0.33560 & 0.03823 \\
\hline LC7 & 0.29495 & 0.22497 & 0.17604 \\
\hline LC 8 & 0.60834 & -0.13162 & 0.33632 \\
\hline LC9 & -0.24476 & 0.52717 & 0.40457 \\
\hline LC10 & 0.43857 & 0.01270 & -0.06277 \\
\hline LC11 & 0.40785 & 0.06833 & 0.03695 \\
\hline $\mathrm{LC} 12$ & 0.48027 & 0.12188 & 0.04514 \\
\hline LC13 & 0.24419 & -0.19997 & 0.46436 \\
\hline $\operatorname{LC} 14$ & 0.17153 & 0.10500 & 0.52946 \\
\hline LC15 & 0.48224 & -0.15762 & 0.26980 \\
\hline LC1 6 & 0.31550 & 0.33075 & 0.12109 \\
\hline $\mathrm{LC} 17$ & 0.08115 & 0.24169 & -0.01723 \\
\hline LC18 & 0.14056 & 0.55794 & -0.08419 \\
\hline LC19 & -0.00792 & -0.03509 & 0.33550 \\
\hline LC20 & 0.53990 & -0.09821 & 0.21777 \\
\hline $\mathrm{LC} 21$ & -0.04098 & 0.34821 & 0.12161 \\
\hline LC22 & 0.22795 & 0.03311 & 0.47620 \\
\hline LC2 3 & -0.04542 & 0.05153 & 0.32188 \\
\hline $\mathrm{LC} 24$ & 0.23606 & 0.48569 & 0.15483 \\
\hline
\end{tabular}


APÊNDICE XXVI - Tabela 12-Descricão das médias, desvios-padrão, valores mínimos e máximos, pela variacão dos niveis de respostas na escala likert pictográfica

\begin{tabular}{|c|c|c|c|c|c|}
\hline & $\mathbf{N}$ & Mínimo & Máximo & Média & $\begin{array}{l}\text { Desvio } \\
\text { padrăo }\end{array}$ \\
\hline LCl1 & 111 & -3 & 3 & .76 & 1,52 \\
\hline LCEA2 & 111 & -3 & 3 &, 30 & 1,83 \\
\hline LCEPP 3 & 111 & -3 & 3 &,- 53 & 1,95 \\
\hline $\mathrm{LCl} 4$ & 111 & -3 & 3 & 2,21 & 1,19 \\
\hline LCI5 & 111 & -3 & 3 & ,98 & 1,56 \\
\hline LCEA6 & 111 & -3 & 3 &,- 79 & 1,71 \\
\hline LCEA7 & 111 & -3 & 3 & 9,01E-02 & 1,91 \\
\hline LCEPP8 & 111 & -3 & 3 &,- 33 & 1,63 \\
\hline LCl9 & 111 & -3 & 3 & 1,80 & 1,17 \\
\hline LCEA10 & 111 & -3 & 3 & 1,07 & 1,72 \\
\hline LCEPP11 & 111 & -3 & 3 &,- 24 & 1,72 \\
\hline LCEA12 & 111 & -3 & 3 &,- 78 & 1,59 \\
\hline LCEPP13 & 111 & -3 & 3 &,- 23 & 1,89 \\
\hline LCEA14 & 111 & -3 & 3 &,- 70 & 1,96 \\
\hline LCEPP15 & 111 & -3 & 3 &,- 50 & 1,86 \\
\hline LCEA16 & 111 & -3 & 3 &, 23 & 2,08 \\
\hline LCEPP17 & 111 & -3 & 3 & 1,79 & 1,51 \\
\hline LCI18 & 111 & -3 & 3 &,- 44 & 1,78 \\
\hline LCl19 & 111 & -1 & 3 & 2,50 & .63 \\
\hline LCEPP20 & 111 & -3 & 3 &,- 27 & 1,73 \\
\hline LCl21 & 111 & -3 & 3 &, 22 & 1,82 \\
\hline LCEPP22 & 111 & -3 & 3 & .42 & 1,52 \\
\hline $\mathrm{LCl} 23$ & 111 & -3 & 3 & 1,31 & 1,46 \\
\hline LCEA24 & 111 & -3 & 3 & 86 & 1,93 \\
\hline
\end{tabular}




\section{APÊNDICE XXVII - TABELA 13-Descricão das freqüências, porcentuais e distribuicão das respostas na escala likert pictográfica: lócus de controle interno}

\begin{tabular}{|c|c|c|c|c|c|c|c|}
\hline & & Frequência & Porcentual & & & encia & Porcentual \\
\hline \multirow[t]{8}{*}{$\mathrm{LCl} 1$} & -3 & 5 & 4,5 & $\mathrm{LCl} 18$ & -3 & 12 & 10,8 \\
\hline & -2 & 7 & 6,3 & & -2 & 28 & 25,2 \\
\hline & -1 & 15 & 13,5 & & -1 & 26 & 23,4 \\
\hline & 1 & 47 & 42,3 & & 1 & 24 & 21,6 \\
\hline & 2 & 30 & 27,0 & & 2 & 18 & 16,2 \\
\hline & 3 & 7 & 6,3 & & 3 & 3 & 2,7 \\
\hline & Total & 111 & 100,0 & & Total & 111 & 100,0 \\
\hline & & Frequência & Porcentual & & & ência & Porcentual \\
\hline \multirow[t]{8}{*}{$\mathrm{LCl} 4$} & -3 & 1 & .9 & $\mathrm{LCl} 19$ & -1 & 1 & 9 \\
\hline & -2 & 3 & 2,7 & & 1 & 2 & 1,8 \\
\hline & -1 & 1 & 9 & & 2 & 48 & 43,2 \\
\hline & 1 & 18 & 16,2 & & 3 & 60 & 54,1 \\
\hline & 2 & 27 & 24,3 & & Total & 111 & 100,0 \\
\hline & 3 & 61 & 55,0 & & & & \\
\hline & Total & 111 & 100,0 & & & & \\
\hline & & Frequência & Porcentual & & & ência & Porcentual \\
\hline \multirow[t]{8}{*}{$\mathrm{LCl} 5$} & -3 & 3 & 2,7 & $\mathrm{LCl} 21$ & -3 & 10 & 9,0 \\
\hline & -2 & 11 & 9,9 & & -2 & 16 & 14,4 \\
\hline & -1 & 9 & 8,1 & & -1 & 18 & 16,2 \\
\hline & 1 & 39 & 35,1 & & 1 & 39 & 35,1 \\
\hline & 2 & 37 & 33,3 & & 2 & 19 & 17,1 \\
\hline & 3 & 12 & 10,8 & & 3 & 9 & 8,1 \\
\hline & Total & 111 & 100,0 & & Total & 111 & 100,0 \\
\hline & & Frequência & Porcentual & & & ência & Porcentual \\
\hline \multirow[t]{7}{*}{ LCI 9} & -3 & 1 & 9 & $\mathrm{LCl} 23$ & -3 & 3 & 2,7 \\
\hline & -2 & 3 & 2,7 & & -2 & 5 & 4,5 \\
\hline & -1 & 3 & 2,7 & & -1 & 8 & 7,2 \\
\hline & 1 & 26 & 23,4 & & 1 & 40 & 36,0 \\
\hline & 2 & 48 & 43,2 & & 2 & 33 & 29,7 \\
\hline & 3 & 30 & 27,0 & & 3 & 22 & 19,8 \\
\hline & Total & 111 & 100,0 & & Total & 111 & 100,0 \\
\hline
\end{tabular}




\section{APÊNDICE XXVIII - TABELA 14 - Descricão das freqüências, porcentuais e distribuição das respostas pela escala likert pictográfica: lócus de controle externo sorte-azar}

\begin{tabular}{|c|c|c|c|c|c|c|c|}
\hline & & Frequência & Porcentual & & \multicolumn{2}{|r|}{ Frequência } & \multirow{2}{*}{$\begin{array}{r}\text { Porcentual } \\
10,8\end{array}$} \\
\hline \multirow[t]{7}{*}{ LCE S-A 2} & -3 & 7 & 6,3 & \multirow[t]{7}{*}{ LCE S-A 12} & -3 & 12 & \\
\hline & -2 & 20 & 18,0 & & -2 & 35 & 31,5 \\
\hline & -1 & 16 & 14,4 & & -1 & 28 & 25,2 \\
\hline & 1 & 38 & 34,2 & & 1 & 26 & 23,4 \\
\hline & 2 & 18 & 16,2 & & 2 & 9 & 8,1 \\
\hline & 3 & 12 & 10,8 & & 3 & 1 & 9 \\
\hline & \multirow[t]{2}{*}{ Total } & 111 & 100,0 & & \multicolumn{2}{|l|}{ Total } & 100,0 \\
\hline & & Frequência & Porcentual & & & Frequência & Porcentual \\
\hline \multirow{9}{*}{ LCE S-A 6} & -3 & 14 & 12,6 & \multirow[t]{7}{*}{ LCE S-A 14} & -3 & 20 & 18,0 \\
\hline & -2 & 35 & 31,5 & & -2 & 35 & 31,5 \\
\hline & -1 & 27 & 24,3 & & -1 & 17 & 15,3 \\
\hline & 0 & 1 & 9 & & 1 & 15 & 13,5 \\
\hline & 1 & 23 & 20,7 & & 2 & 18 & 16,2 \\
\hline & 2 & 5 & 4,5 & & 3 & 6 & 5,4 \\
\hline & 3 & 6 & 5,4 & & Total & 111 & 100,0 \\
\hline & \multirow[t]{2}{*}{ Total } & 111 & 100,0 & & & & \\
\hline & & Frequência & Porcentual & & & Frequência & Porcentual \\
\hline \multirow[t]{8}{*}{ LCE S-A 7} & -3 & 7 & 6,3 & \multirow{7}{*}{ LCE S-A 16} & -3 & 10 & 9,0 \\
\hline & -2 & 27 & 24,3 & & -2 & 24 & 21,6 \\
\hline & -1 & 18 & 16,2 & & -1 & 17 & 15,3 \\
\hline & 1 & 26 & 23,4 & & 1 & 19 & 17,1 \\
\hline & 2 & 22 & 19,8 & & 2 & 22 & 19,8 \\
\hline & 3 & 11 & 9,9 & & 3 & 19 & 17,1 \\
\hline & \multirow[t]{2}{*}{ Total } & 111 & 100,0 & & Total & 111 & 100,0 \\
\hline & & Frequência & Porcentual & & & Frequência & Porcentual \\
\hline \multirow[t]{7}{*}{ LCE S-A 10} & -3 & 4 & 3,6 & LCE S-A 24 & -3 & 8 & 7,2 \\
\hline & -2 & 10 & 9,0 & & -2 & 14 & 12,6 \\
\hline & -1 & 13 & 11,7 & & -1 & 8 & 7,2 \\
\hline & 1 & 24 & 21,6 & & 1 & 31 & 27,9 \\
\hline & 2 & 40 & 36,0 & & 2 & 25 & 22,5 \\
\hline & 3 & 20 & 18,0 & & 3 & 25 & 22,5 \\
\hline & Total & 111 & 100,0 & & Total & 111 & 100,0 \\
\hline
\end{tabular}




\section{APÊNDICE XXIX - TABELA 15 - Descricão sobre as freqüências, porcentuais e distribuicão das respostas na escala likert pictográfica: lócus externo pessoas poderosas}

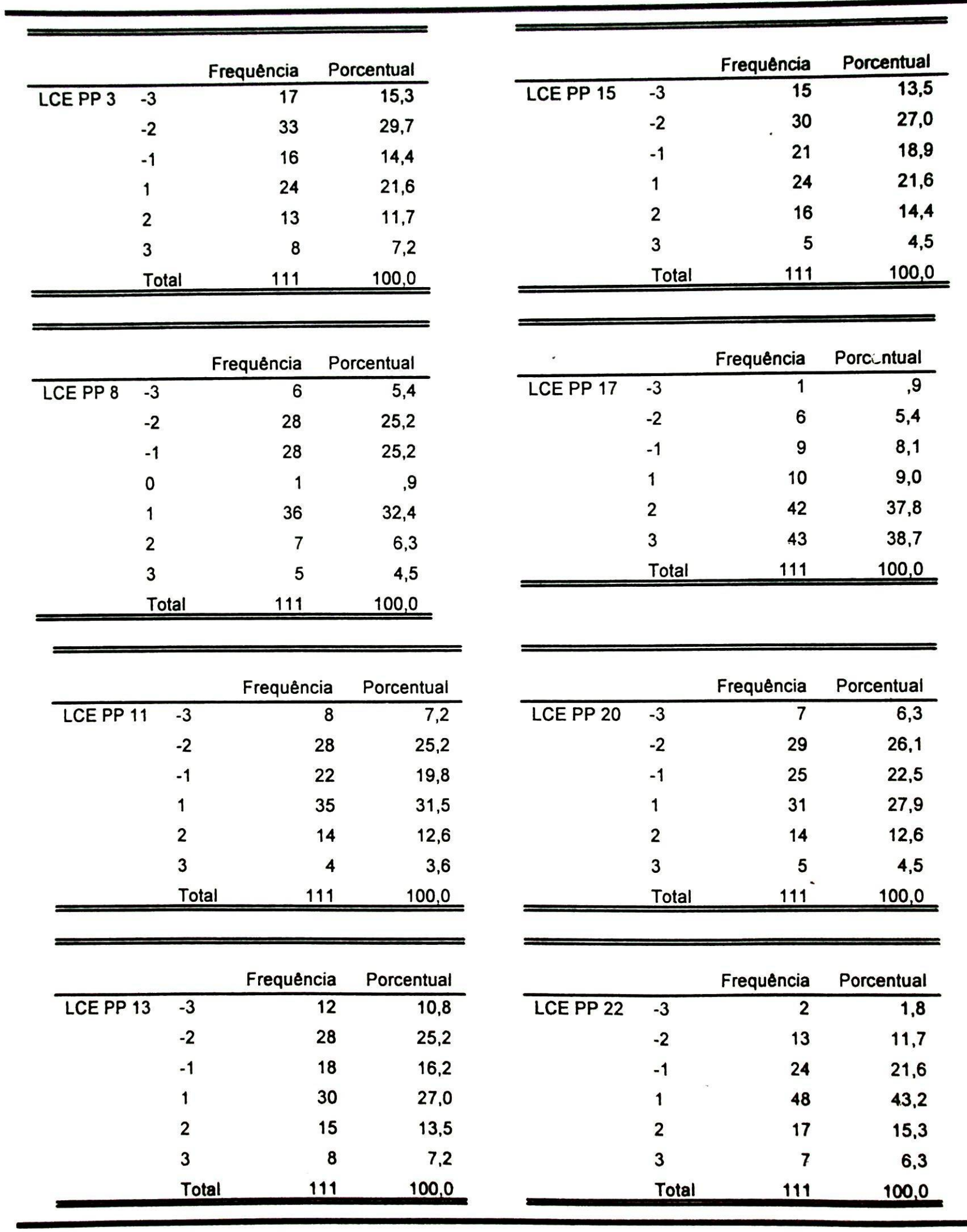


APÊNDICE XVII - Histograma de Freqüências sobre a variacão e curva normal de distribuicão ao lócus de controle interno

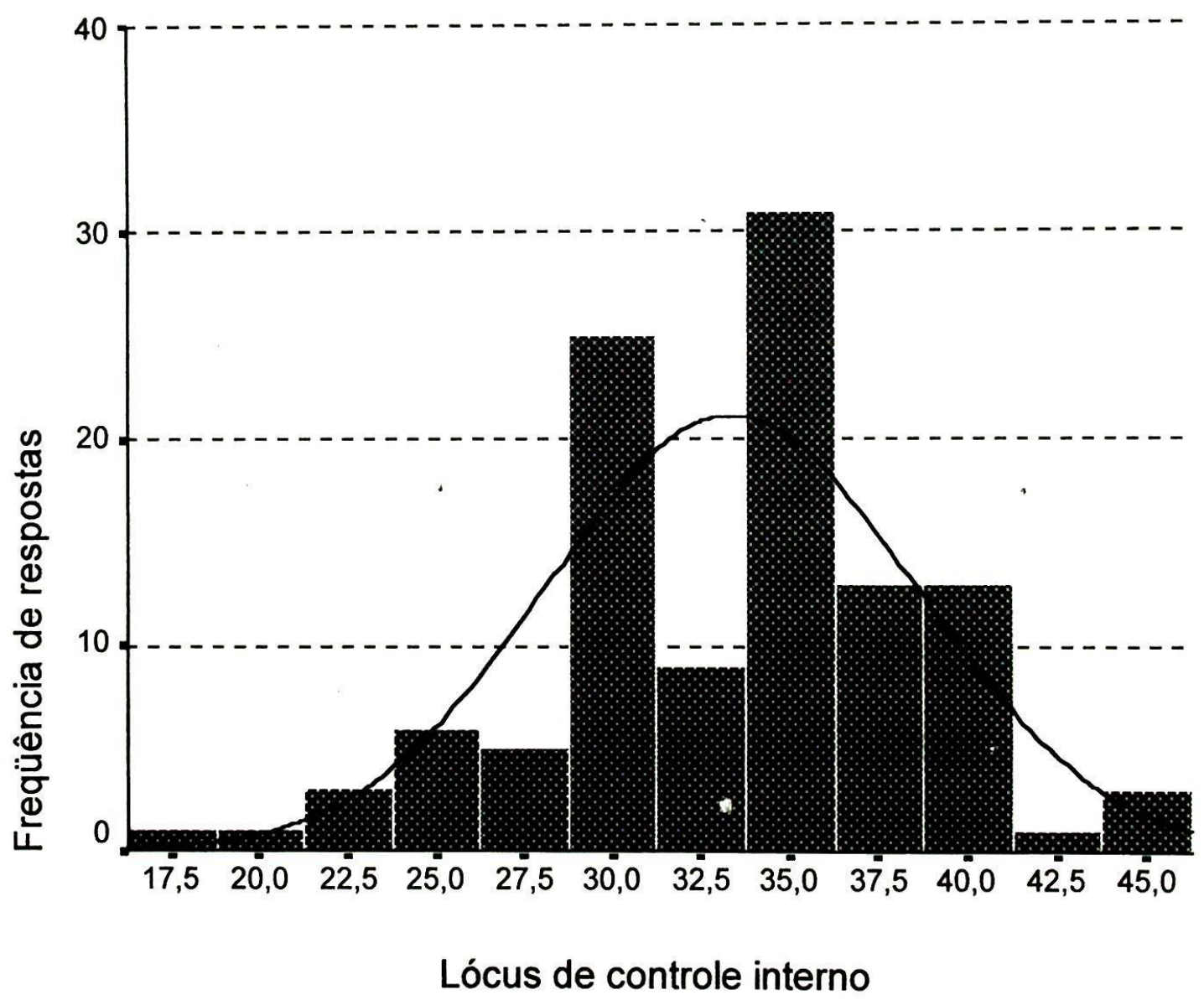




\section{APENNDICE XXXI - Histograma de Freqüências sobre a variacão e curva normal de distribuição ao lócus de controle externo sorte-azar}

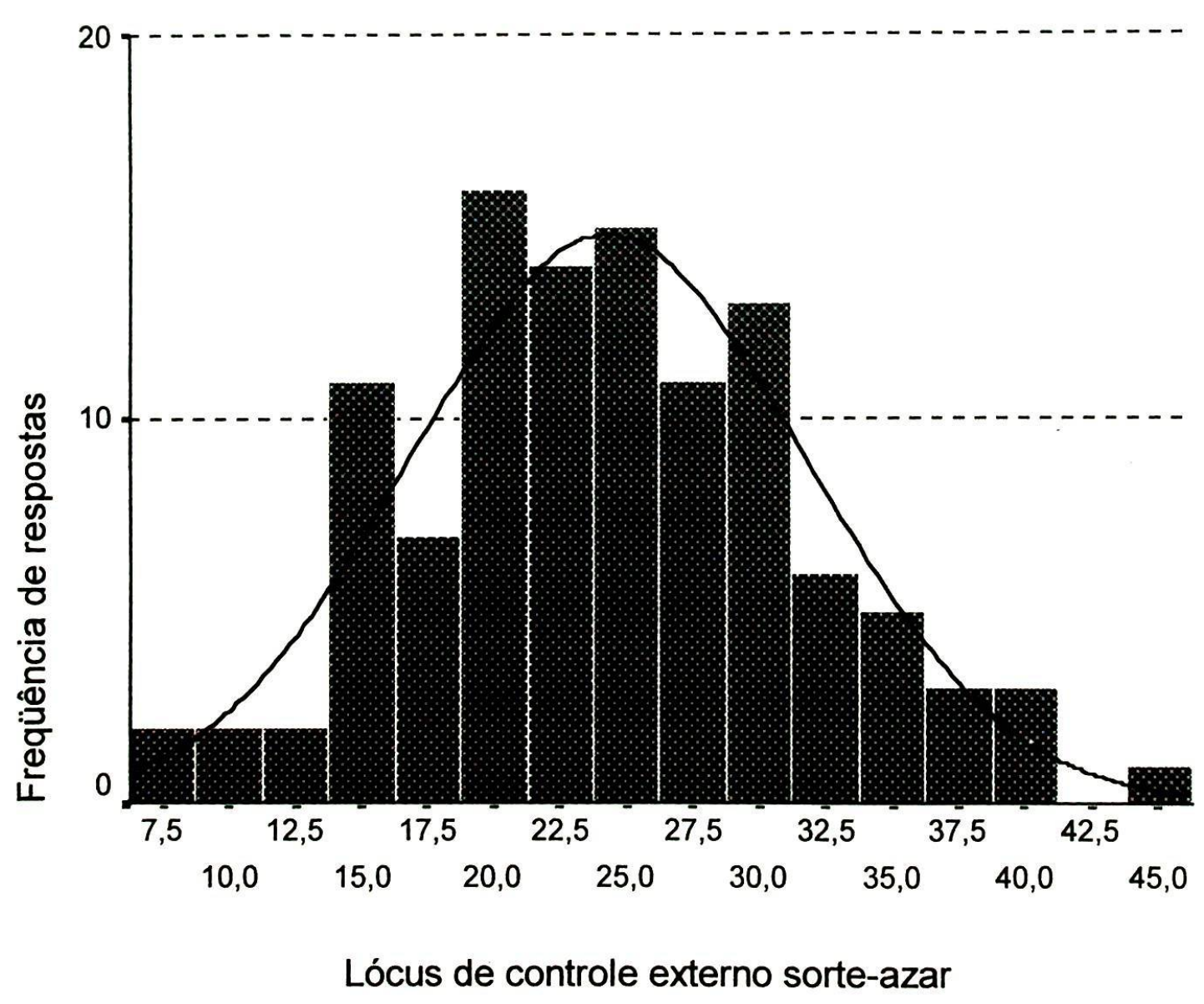


APÊNDICE XXXII - Histograma de Freqüências sobre a variacão e curva normal de distribuição ao lócus de controle externo pessoas poderosas

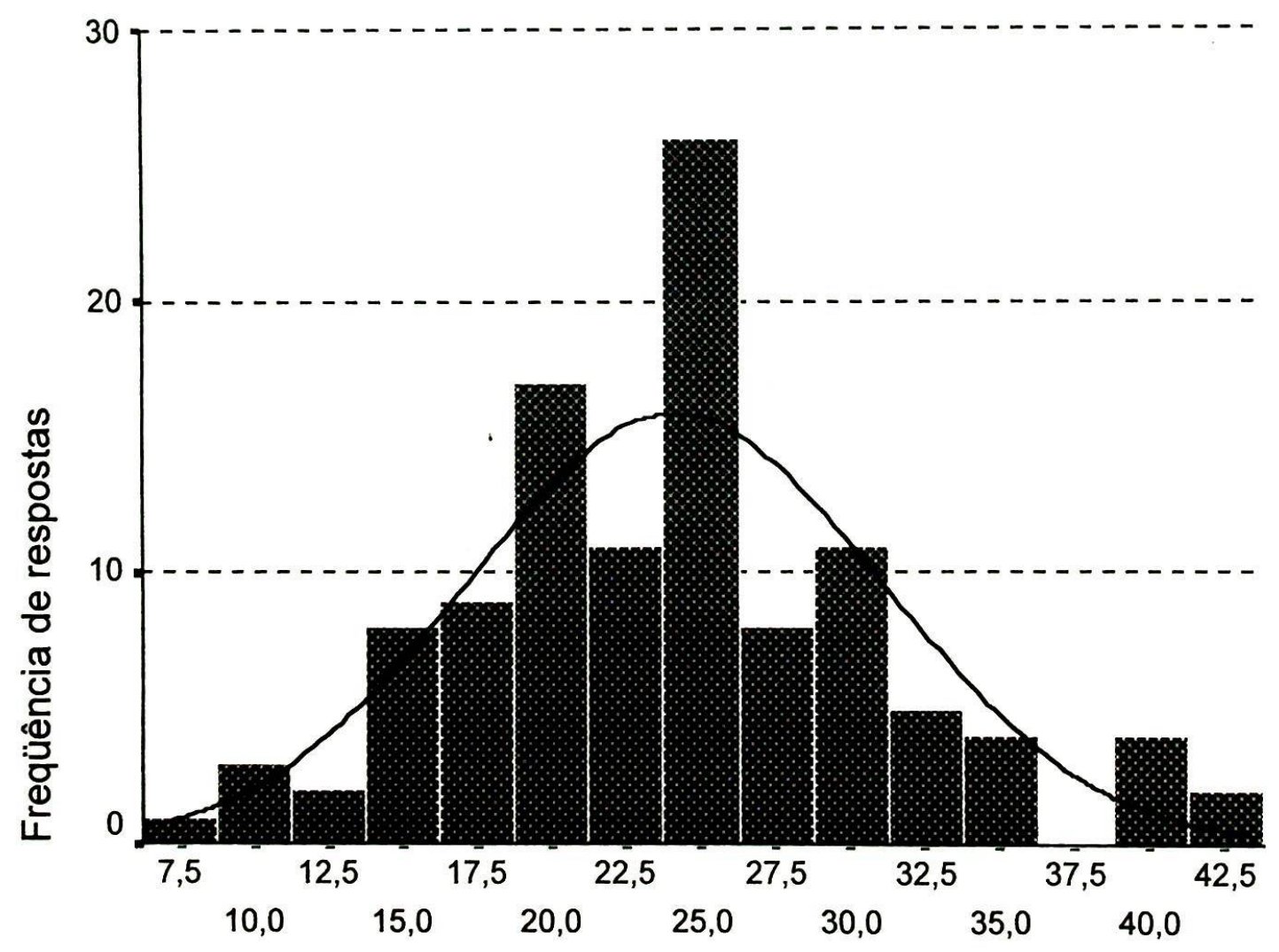

Lócus de controle externo pessoas-poderosas 